\title{
Geology and Nonfuel Mineral Deposits of Greenland, Europe, Russia, and Northern Central Asia
}

By Warren J. Nokleberg ${ }^{1}$, Walter J. Bawiec ${ }^{2}$, Jeff L. Doebrich ${ }^{2}$, Bruce R. Lipin ${ }^{2}$, Robert J. Miller ${ }^{1}$, Greta J. Orris ${ }^{3}$, and Michael L. Zientek ${ }^{4}$

U.S. Geological Survey: ${ }^{1}$ Western Region Center, Menlo Park California ${ }^{2}$ National Center, Reston, Virginia, ${ }^{3}$ Tucson Field Office, Tucson Arizona, ${ }^{4}$ Spokane Field Office, Spokane, Washington

Open File Report 2005-1294D

U.S. Department of the Interior U.S. Geological Survey 


\section{U.S. Department of the Interior \\ Gale A. Norton, Secretary}

\section{U.S. Geological Survey \\ P. Patrick Leahy, Acting Director}

U.S. Geological Survey, Reston, Virginia 2005

Revised and reprinted: 2005

For product and ordering information:

World Wide Web: http://www.usgs.gov/pubprod

Telephone: 1-888-ASK-USGS

For more information on the USGS - the Federal source for science about the Earth, its natural and living resources, natural hazards, and the environment:

World Wide Web: http://www.usgs.gov

Telephone: 1-888-ASK-USGS

Suggested citation:

Nokleberg, W.J., Bawiec, W.J., Doebrich, J.L., Lipin, B.R., Miller, R.M., Orris, G.J., and Zientek, M.J., 2005, Geology and nonfuel mineral deposits of Greenland, Europe, Russia, and northern Central Asia: U.S. Geological Survey Open-File Report 2005-1294D, 182 p. [URL http://pubs.usgs.gov/of/2005/1294/d].

Any use of trade, product, or firm names is for descriptive purposes only and does not imply endorsement by the U.S. Government.

Although this report is in the public domain, permission must be secured from the individual copyright owners to reproduce any copyrighted material contained within this report. 


\section{Contents}

Contents

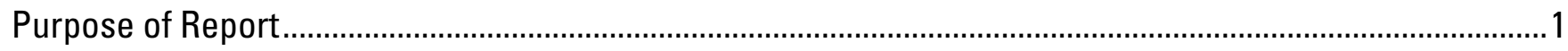

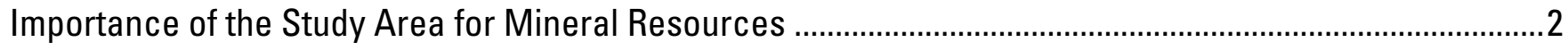

Region Covered by Report .......................................................................................................................

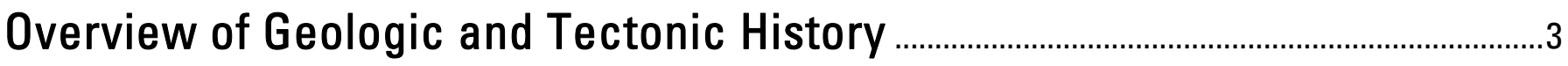

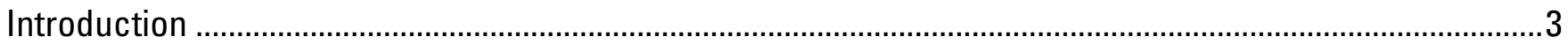

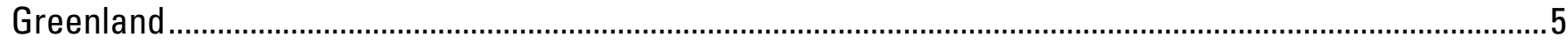

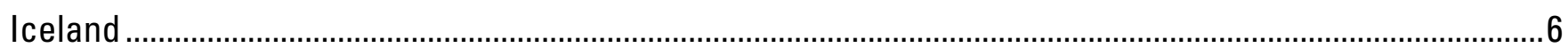

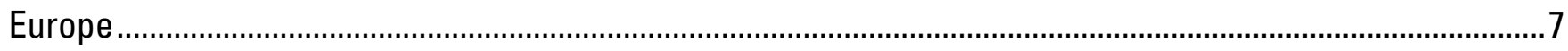

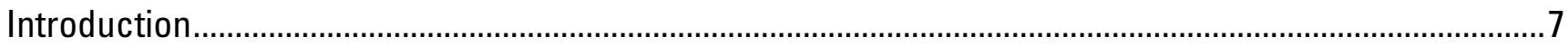

Major Geologic and Tectonic Provinces ...................................................................................................

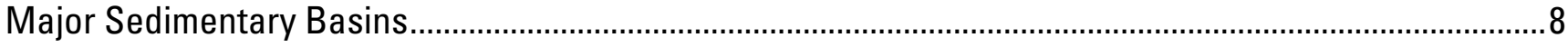

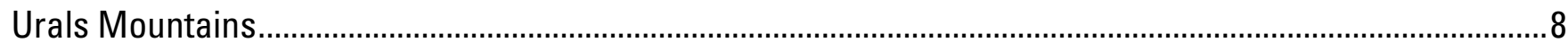

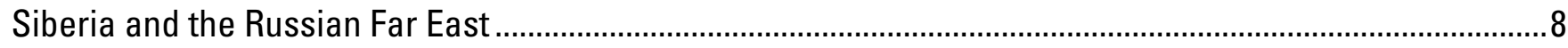

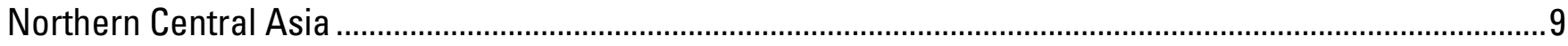

Altay-Sayan Mountains of Northern Central Asia …………………………………………………....

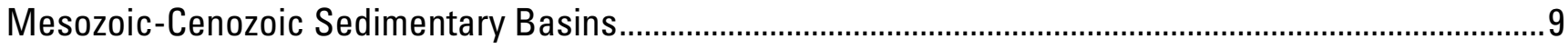

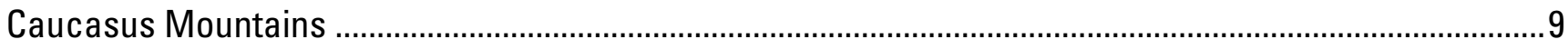

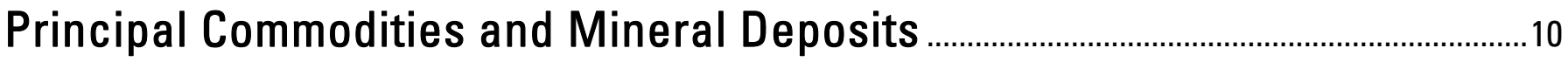

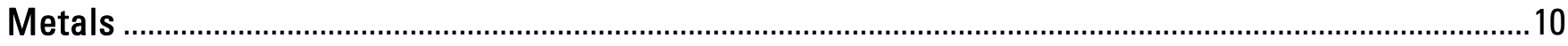

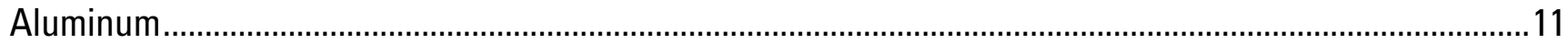

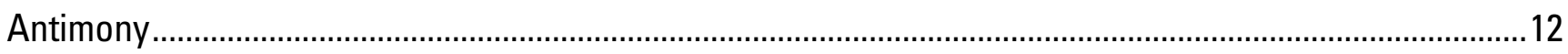

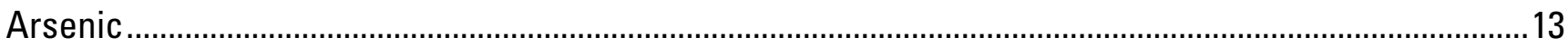

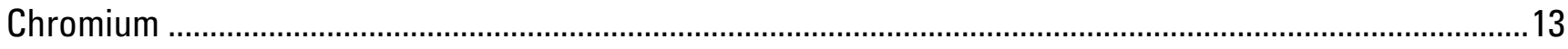

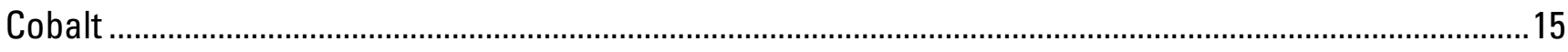

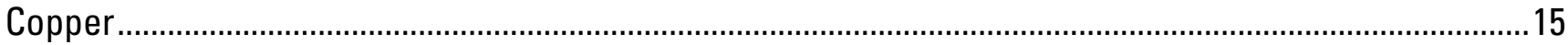

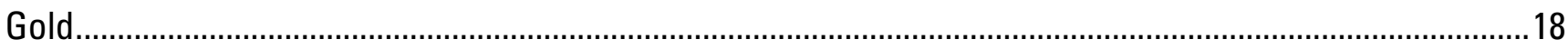

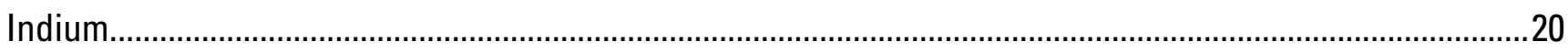

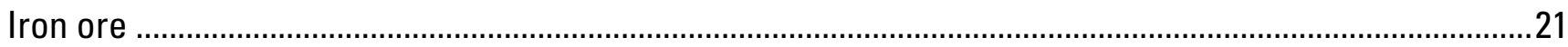

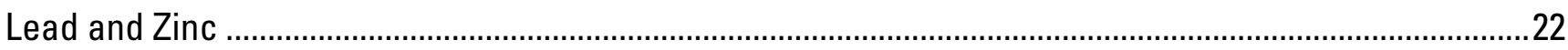

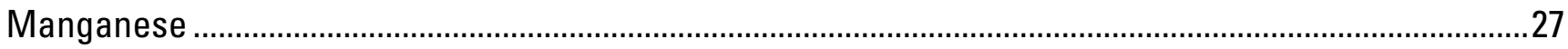

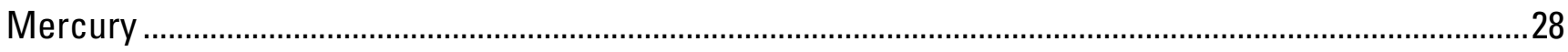

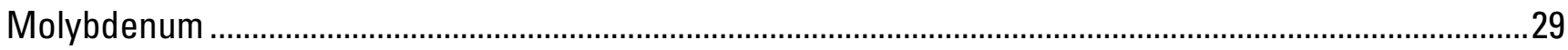

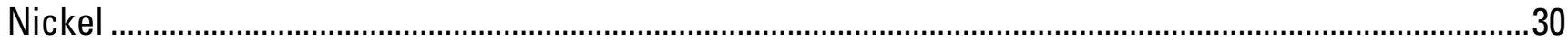

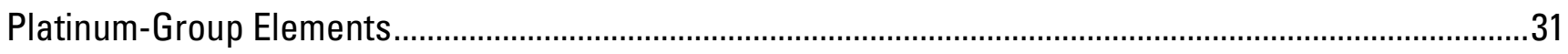

Rare-Earth Metals, including Niobium and Tantalum ........................................................................3

Silver

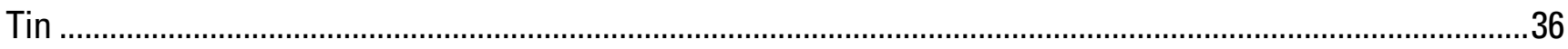

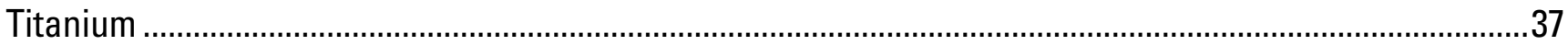




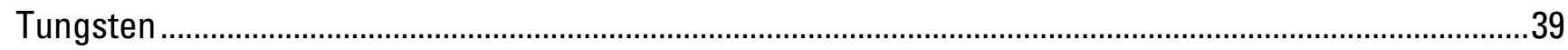

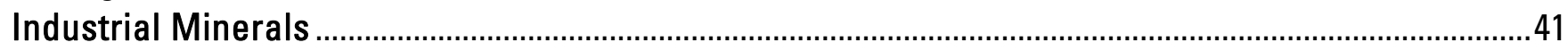

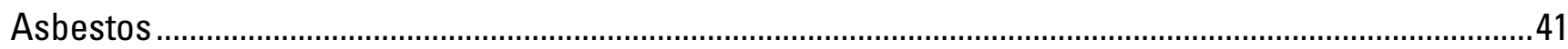

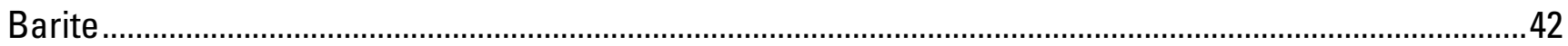

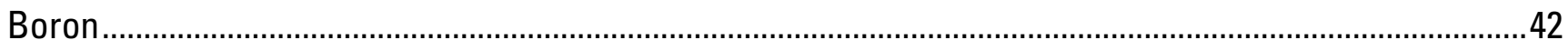

Clay (Kaolin, Bentonite, and Fuller's Earth) ……………………............................................................. 43

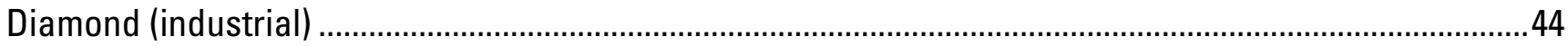

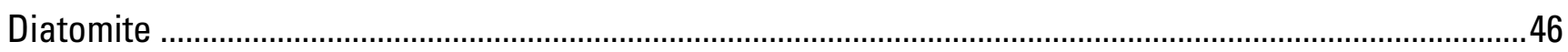

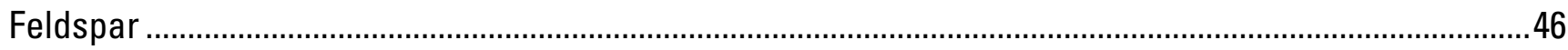

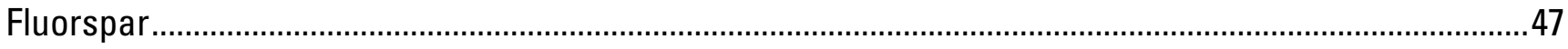

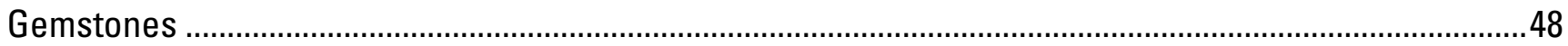

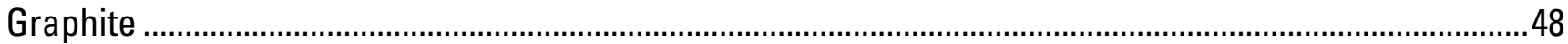

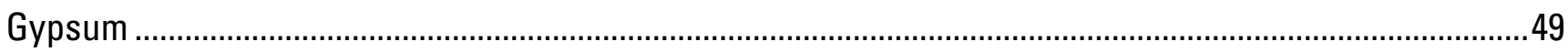

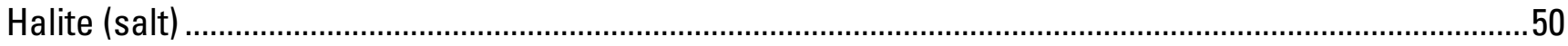

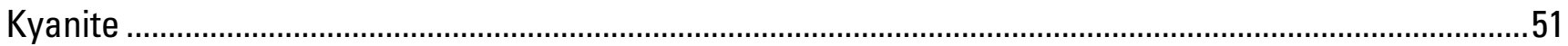

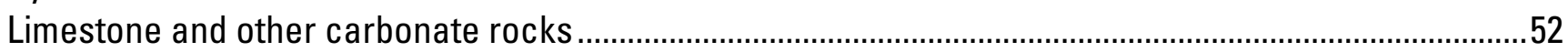

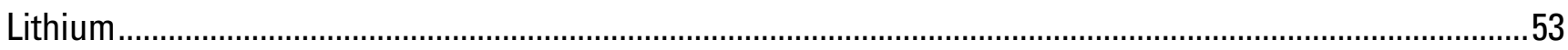

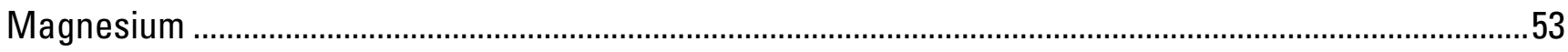

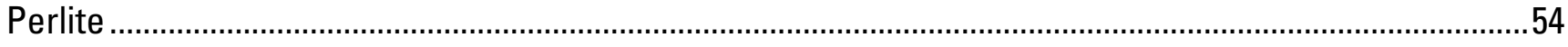

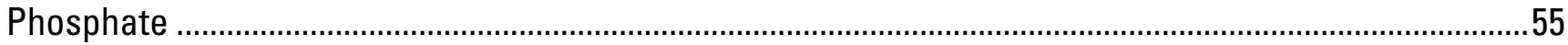

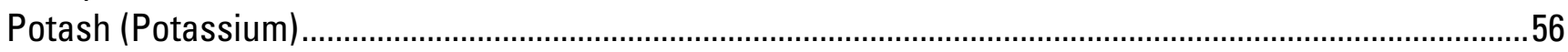

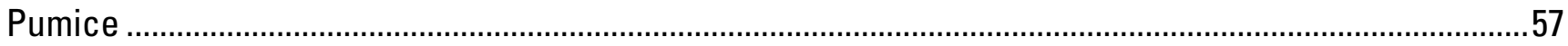

Silic on

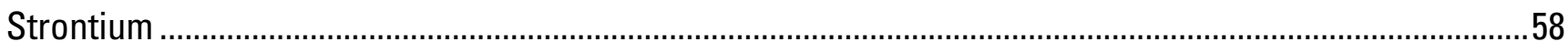

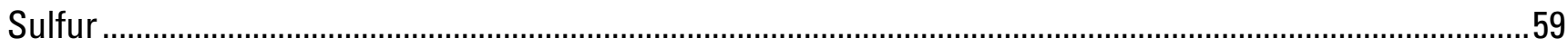

Summaries of Recent Regional Mineral Exploration and Major Active

Mines

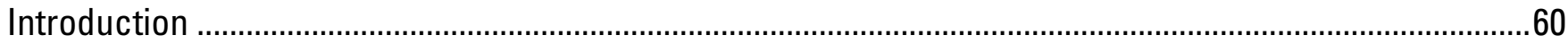

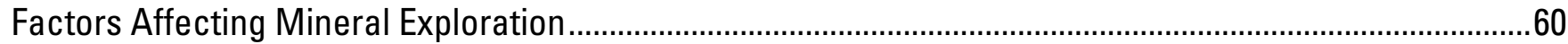

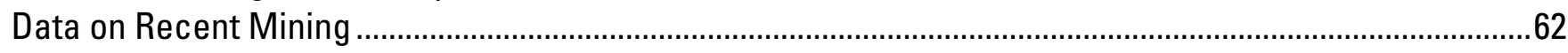

Mineral Exploration and Recent Mining in Greenland............................................................................62

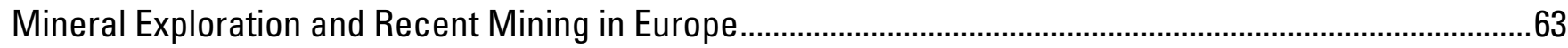

Albania

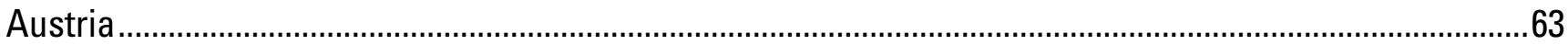

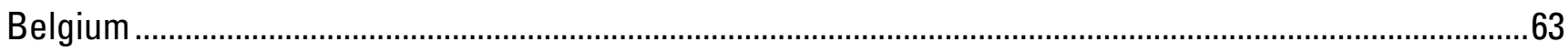

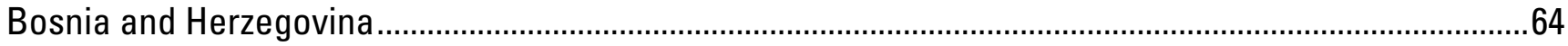

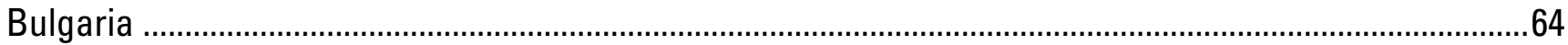

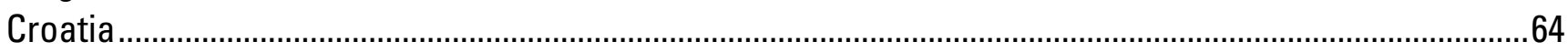

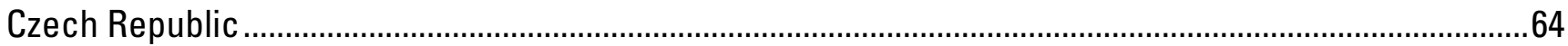

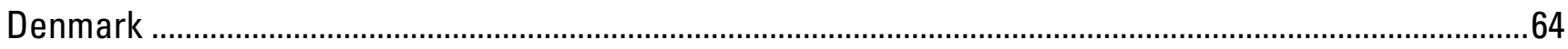

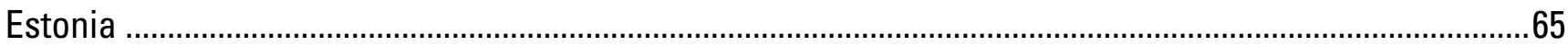

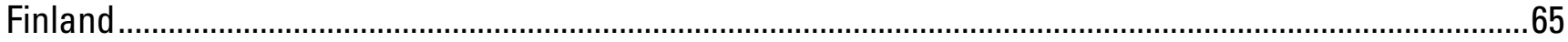

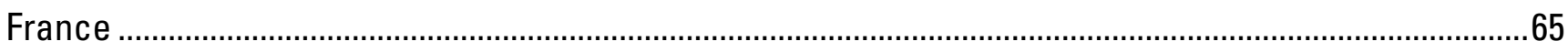

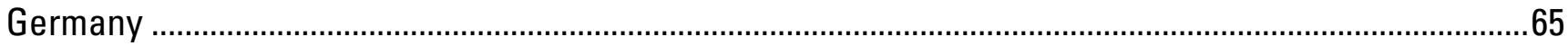




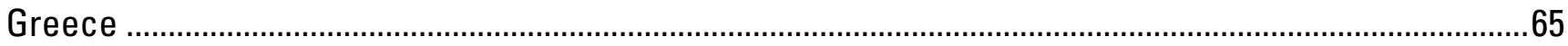

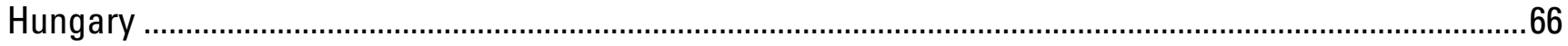

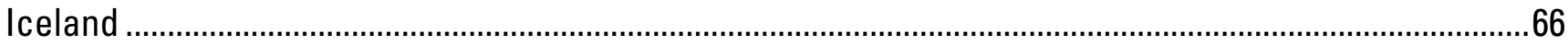

Ireland

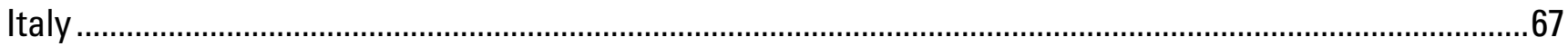

Latvia

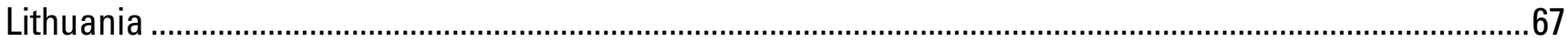

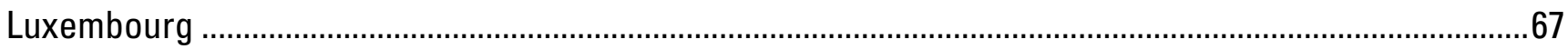

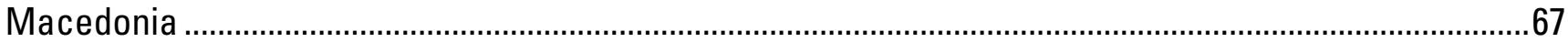

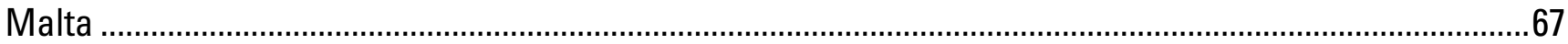

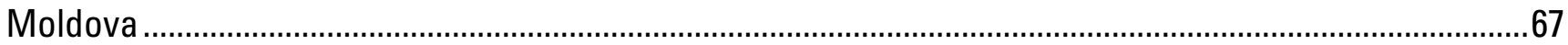

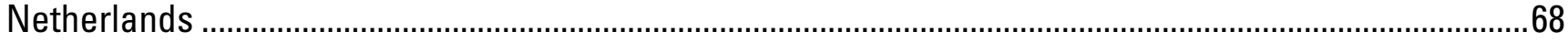

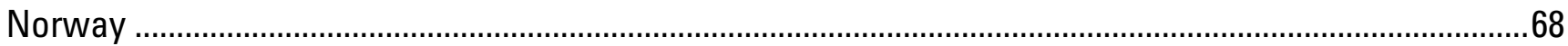

Poland

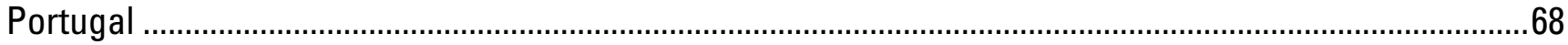

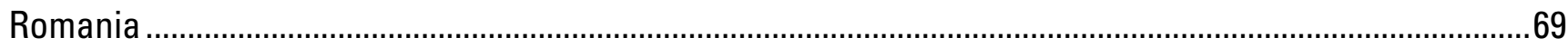

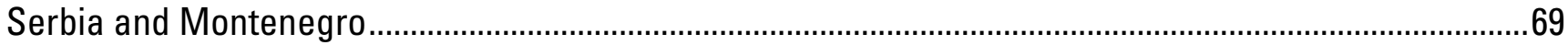

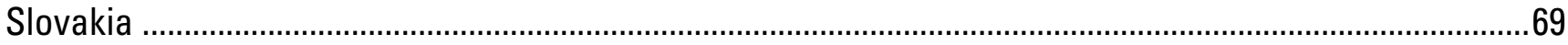

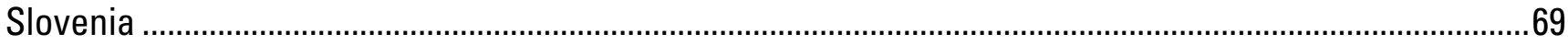

Spain

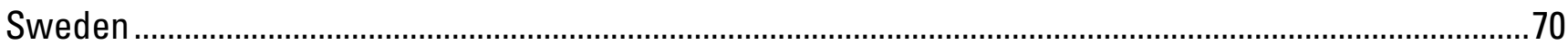

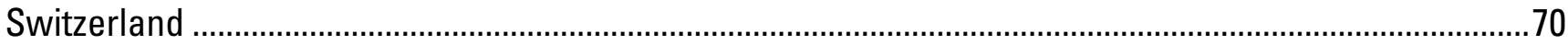

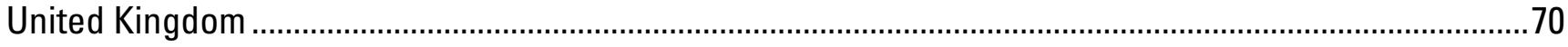

Mineral Exploration and Recent Mining in Russia, Belarus, and Ukraine...........................................71

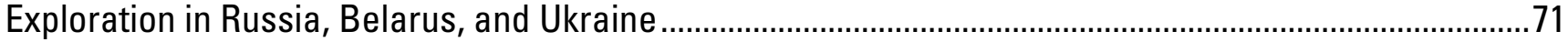

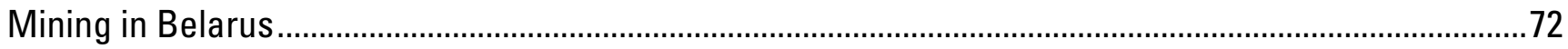

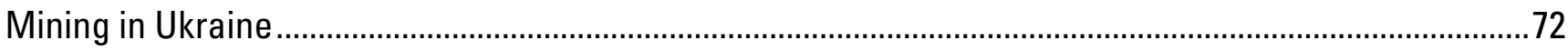

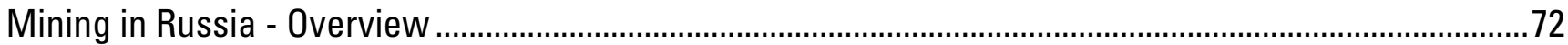

Mineral Exploration and Recent Mining in Northern Central Asia ..................................................76

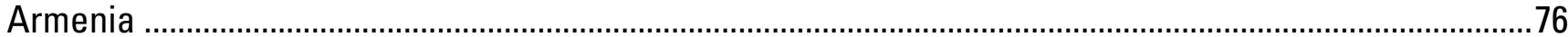

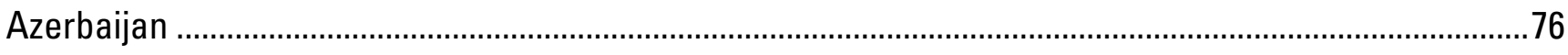

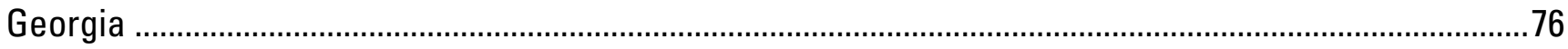

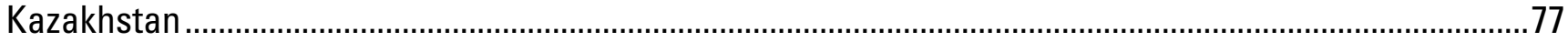

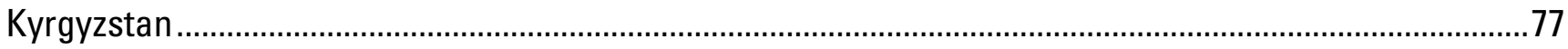

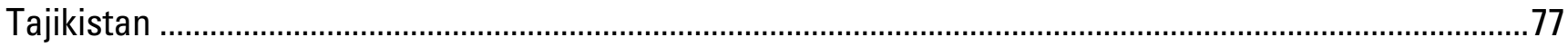

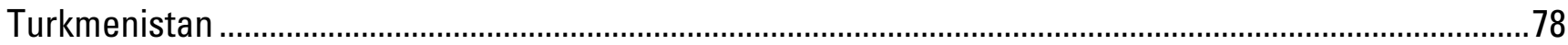

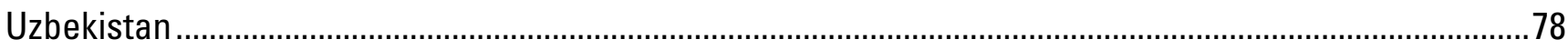

Potential for Undiscovered Mineral Resources ...............................................................79

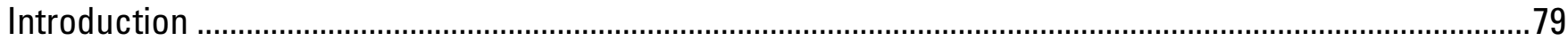

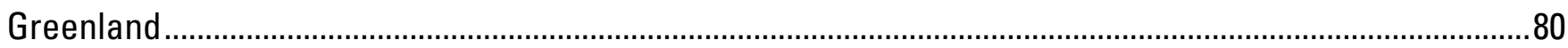

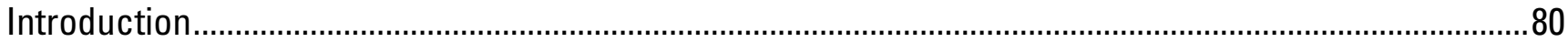

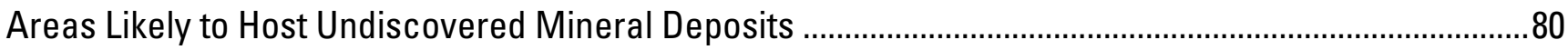

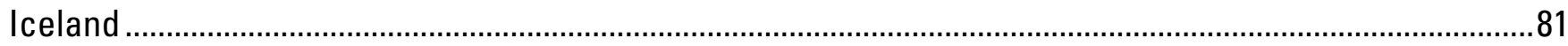

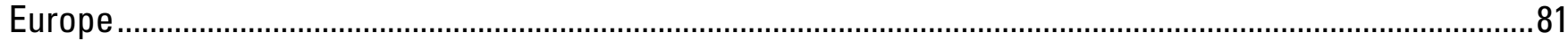




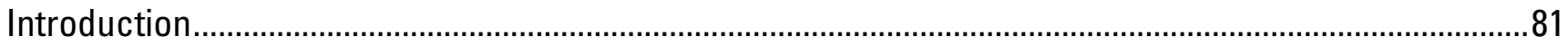

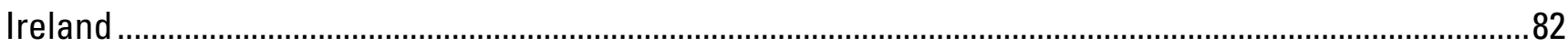

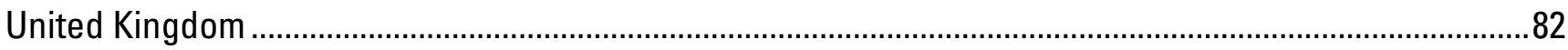

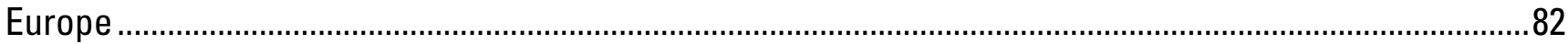

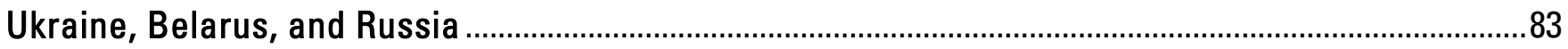

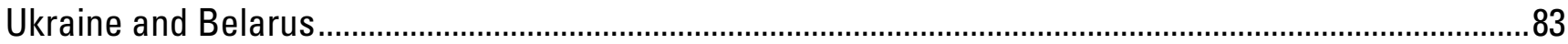

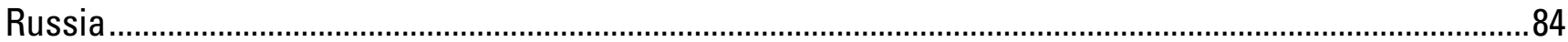

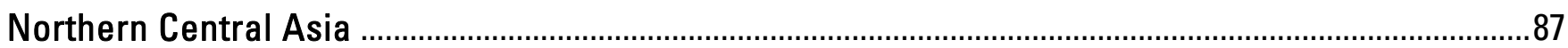

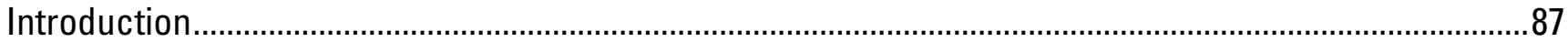

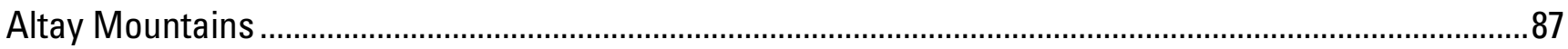

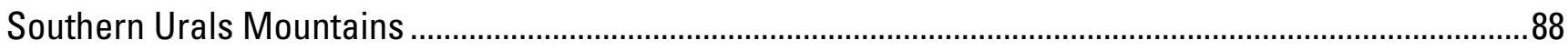

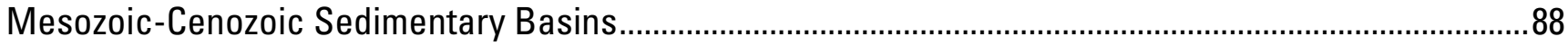

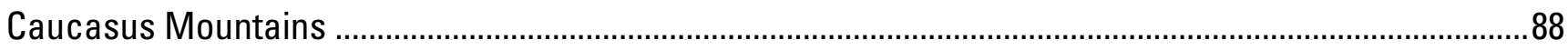

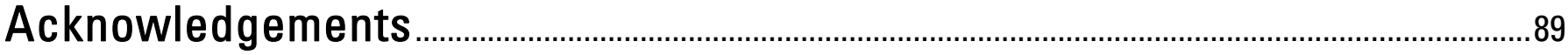

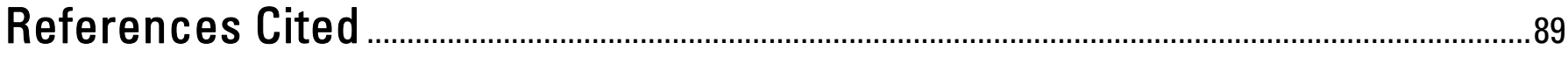

\section{Tables}

Table 1. Principal nonfuel mineral commodities produced in Greenland, Europe and Northern Central Asia. Adapted from U.S. Geological Survey Minerals Yearbook, v. III. - Area Reports: International, U.S. Geological Survey (2002), U.S. Geological Survey (2004), and from Table 2 (this report). Commodities in bold indicate countries that are among major current world producers according to U.S. Geological Survey (2004)...

Table 2. A. Mineral deposit name, location, principal commodities, type, and reference for the major metallic mineral deposits in Greenland, Europe, and Northern Central Asia

B. Mineral deposit name, location, principal commodities, type, and reference for the major non-metallic mineral deposits in Greenland, Europe, and Northern Central Asia

Table 3. Mineral deposit types, processes of formations, and examples.

Table 4. Bauxite - data for 2003 for world mine production, reserves, and reserve base for the study area and for the leading global producer (U.S. Geological Survey, 2004).

Table 5. Antimony - data for 2003 for world mine production, reserves, and reserve base for the study area and for the leading global producer (U.S. Geological Survey, 2004).

Table 6. Arsenic - data for 2003 for world mine production, reserves, and reserve base for the study area and for the leading global producer (U.S. Geological Survey, 2004).

Table 7. Chromium - data for 2003 for world mine production, reserves, and reserve base for the study area and for the leading global producer (U.S. Geological Survey, 2004).

Table 8. Cobalt - data for 2003 for world mine production, reserves, and reserve base for the study area and for the leading global producer (U.S. Geological Survey, 2004).

Table 9. Copper - data for 2003 for world mine production, reserves, reserve base, and resource base for the study area and for the leading global producer (U.S. Geological Survey, 2004; Singer, 1995). 
Table 10. Gold - data for 2003 for world mine production, reserves, and reserve base for the study area and for the leading global producer (U.S. Geological Survey, 2004).

Table 11. Indium - data for 2003 for world mine production, reserves, and reserve base for the study area and for the leading global producer (U.S. Geological Survey, 2004).

Table 12. Iron ore - data for 2003 for world mine production, reserves, and reserve base for the study area and for the leading global producer (U.S. Geological Survey, 2004).

Table 13. Lead - data for 2003 for world mine production, reserves, and reserve base for the study area and for the leading global producer (U.S. Geological Survey, 2004). 23

Table 14. Zinc - data for 2003 for world mine production, reserves, and reserve base for the study area and for the leading global producer (U.S. Geological Survey, 2004).

Table 15. Manganese - data for 2003 for world mine production, reserves, and reserve base for the study area and for the leading global producer (U.S. Geological Survey, 2004). 27

Table 16. Manganese resources in the ocean (U.S. Geological Survey, 2004) 28

Table 17. Mercury - data for 2003 for world mine production, reserves, and reserve base for the study area and for the leading global producer (U.S. Geological Survey, 2004).

Table 18. Molybdenum - data for 2003 for world mine production, reserves, and reserve base for the study area and for the leading global producer (U.S. Geological Survey, 2004).

Table 19. Nickel - data for 2003 for world mine production, reserves, and reserve base for the study area and for the leading global producer (U.S. Geological Survey, 2004).

Table 20. Platinum-group elements - data for 2003 for world mine production, reserves, and reserve base for the study area and for the leading global producer (U.S. Geological Survey, 2004).

Table 21. Rare-earth metals - data for 2003 for world mine production, reserves, and reserve base for the study area and for the leading global producer (index mundi, 2004; U.S. Geological Survey, 2004).

Table 22. Silver - data for 2003 for world mine production, reserves, and reserve base for the study area and for the leading global producer (U.S. Geological Survey, 2004).

Table 23. Tin - data for 2003 for world mine production, reserves, and reserve base for the study area and for the leading global producer (U.S. Geological Survey, 2004).

Table 24. Titanium mineral concentrate (ilmenite) - data for 2003 for world mine production, reserves, and reserve base for the study area and for the leading global producer (U.S. Geological Survey, 2005).

Table 25. Titanium mineral concentrate (rutile) - data for 2003 for world mine production, reserves, and reserve base for the study area and for the leading global producer (U.S. Geological Survey, 2005).

Table 26. Tungsten - data for 2003 for world mine production, reserves, and reserve base for the study area and for the leading global producer (U.S. Geological Survey, 2004).

Table 27. Asbestos - data for 2003 for world mine production, reserves, and reserve base for the study area and for the leading global producer (U.S. Geological Survey, 2004).

Table 28. Barite - data for 2003 for world mine production, reserves, and reserve base for the study area and for the leading global producer (U.S. Geological Survey, 2004).

Table 29. Boron - data for 2003 for world mine production, reserves, and reserve base for the study area and for the leading global producer (U.S. Geological Survey, 2004).

Table 30. Kaolin - data for 2003 for world mine production, reserves, and reserve base for the study area and for the leading global producer (U.S. Geological Survey, 2004). 
Table 31. Bentonite - data for 2003 for world mine production, reserves, and reserve base for the study area and for the leading global producer (U.S. Geological Survey, 2004).

Table 32. Diamond (industrial) - data for 2003 for world mine production, reserves, and reserve base for the study area and for the leading global producer (U.S. Geological Survey, 2005).

Table 33. Diatomite - data for 2003 for world mine production, reserves, and reserve base for the study area and for the leading global producer (U.S. Geological Survey, 2004).

Table 34. Feldspar - data for 2003 for world mine production, reserves, and reserve base for the study area and for the leading global producer (U.S. Geological Survey, 2004).

Table 35. Fluorspar - data for 2003 for world mine production, reserves, and reserve base for the study area and for the leading global producer (U.S. Geological Survey, 2004).

Table 36. Graphite - data for 2003 for world mine production, reserves, and reserve base for the study area and for the leading global producer (U.S. Geological Survey, 2004).

Table 37. Gypsum - proportion data for 2003 for world mine production for the study area and for the leading global producer (U.S. Geological Survey, 2004).

Table 38. Halite (salt) - proportion data for 2003 for world mine production for the study area and for the leading global producer (U.S. Geological Survey, 2004).

Table 39. Kyanite - data for 2003 for world mine production, reserves, and reserve base for the study area and for the leading global producer (U.S. Geological Survey, 2004).

Table 40. Lime and limestone - data for 2003 for world mine production, reserves, and reserve base for the study area and for the leading global producer (U.S. Geological Survey, 2004).........52

Table 41. Lithium - data for 2003 for world mine production, reserves, and reserve base for the study area and for the leading global producer (U.S. Geological Survey, 2004).

Table 42. Magnesite - data for 2003 for world mine production, reserves, and reserve base for the study area and for the leading global producer (U.S. Geological Survey, 2004).

Table 43. Perlite - data for 2003 for world mine production, reserves, and reserve base for the study area and for the leading global producer (U.S. Geological Survey, 2004).

Table 44. Phosphate rock - data for 2003 for world mine production, reserves, and reserve base for the study area and for the leading global producer (U.S. Geological Survey, 2004).

Table 45. Potassium - data for 2003 for world mine production, reserves, and reserve base for the study area and for the leading global producer (U.S. Geological Survey, 2004).

Table 46. Pumice - data for 2003 for world mine production, reserves, and reserve base for the study area and for the leading global producer (U.S. Geological Survey, 2004).

Table 47. Silicon - data for 2003 for world mine production, reserves, and reserve base for the study area and for the leading global producer (U.S. Geological Survey, 2004).

Table 48. Strontium - data for 2003 for world mine production for the study area and for the leading global producer (U.S. Geological Survey, 2004).

Table 49. Sulfur - data for 2003 for world mine production for the study area and for the leading global producer (U.S. Geological Survey, 2004).

\section{Figures}

Figure 1. Areas of the regional reports. The area of this report is in gray 138

Figure 2. Schematic political boundary map showing location of countries covered in this report. 139

Figure 3. Digital elevation image of the study area with names of major geographic features 
Figure 4. Principal layers of the Earth....

Figure 5. Diagram illustrating the plate tectonic setting in which mineral deposits are formed ....................142

Figure 6. Generalized regional geologic base map of the study area showing age and distribution of major rock units

Figure $7(A-E)$. Distribution of principal nonfuel mineral deposits in the study area for metallic commodities

Figure $8(A-D)$. Distribution of principal nonfuel mineral deposits in the study area for industrial (non-metallic) commodities.

Figure 9. Schematic laterite profile showing the progression of weathering effects on rock........................153

Figure 10. Schematic cross section illustrating the characteristic features of volcanogenic massive sulfide deposits

Figure 11. Schematic east-west longitudional cross section of Talnakh intrusion at NorilskTalnakh copper-nickel-PGE (platinum group elements) sulfide deposit, northern Siberia, Russia

Figure 12. Cross section of a stratovolcano showing the relative locations of porphyry copper deposits, lead and zinc veins, gold-silver veins, and sulfur deposits

Figure 13. Schematic geologic map of the Dukat gold-silver epithermal vein deposit, Russian Northeast. 157

Figure 14. Schematic cross section of Kuperscheifer-type sediment-hosted copper deposit.......................158

Figure 15. Schematic cross section of the Keretti Mine, Outokumpu, Finland 159

Figure 16. Schematic geological map (A) and geological section (B) of the world-class

Kalmakyr copper deposit related to granitic intrusions (porphyry copper deposit), Uzbekistan

Figure 17. Schematic cross section of the Dzhezkazgan sediment-hosted copper deposit in Kazakhstan

Figure 18. Geological section across the eastern part of the Murantau gold district, Uzbekistan, along the profile of deep drill holes

Figure 19. Schematic geologic map of the Sukhoy Log black-shale-hosted gold deposit, southern Siberia, Russia 163

Figure 20. Formation of placer gold deposikts and related placer titanium and platinum-group element (so-called heavy mineral) deposits .164

Figure 21. Schematic geologic map of the Pobeda ironstone deposit, Russian Northeast...... .165

Figure 22. Schematic diagram of an oceanic extensional tectonic (rift) setting where plates are moving away from each other 166

Figure 23. Schematic cross section illustrating the characteristic features of sedimentary exhalative lead and zinc deposits

Figure 24. Schematic reconstructed north-south cross section of the Skaergaard intrusion showing the approximate location of the Platinova Reef.

Figure 25. Schematic geologic map of the Kondyor mafic-ultramafic intrusion, central part of Russian Far East

Figure 26. Schematic geologic map of the Gornoye Ozero carbonatite-related rare-earth metal deposit, Russian Northeast.

Figure 27. Schematic geologic map of Dalnegorsk boron skarn deposit in Russian Southeast.

Figure 28. Schematic cross section illustrating model for formation of a diamond kimberlite pipe .172

Figure 29. Schematic cross section illustrating model for formation of sedimentary potash deposits. 


\title{
Geology and Nonfuel Mineral Deposits of Greenland, Europe, Russia, and Northern Central Asia
}

\author{
By Warren J. Nokleberg', Walter J. Bawiec ${ }^{2}$, Jeff L. Doebrich³, Bruce R. Lipin², Robert M. Miller', \\ Greta Orris ${ }^{4}$, and Michael L. Zientek ${ }^{5}$
}

'U.S. Geological Survey: 'Western Region Center, Menlo Park California
${ }^{2}$ National Center, Reston, Virginia, ${ }^{3}$ Reno Field Office, Reno, Nevada
${ }^{4}$ Tucson Field Office, Tucson Arizona, ${ }^{5}$ Spokane Field Office, Spokane, Washington

\section{Abstract}

This report summarizes the geology and nonfuel mineral resources of Greenland, Europe, Russia, and Northern Central Asia and is a preliminary part of a major U.S. Geological Survey study called the Global Mineral Resource Assessment Project. This report is one of a series of regional reports covering the world and provides basic data on the identified resources and geologic setting, together with a brief appraisal of the potential for undiscovered mineral resources. The data in the regional report are derived from published information. An important source of data on production statistics, economic factors that affect the mineral industries, and historical information, is available in U.S. Geological Survey (USGS) publications Minerals Yearbook and the annual Mineral Commodity Summaries (available at http://minerals.usgs.gov/minerals).

In terms of production of metallic commodities and industrial minerals in recent years (U.S. Geological Survey, 2003, 2004, 2005), Greenland, the countries comprising Europe and Northern Central Asia, and Russia were major or moderate producers of aluminum, antimony, arsenic, asbestos, barite, bentonite boron, chromium, cobalt, copper, diamond, diatomite, feldspar, fluorspar, gemstones, gold, graphite, gypsum indium, iron ore, iron ore, kaolin, kyanite, lead, lithium, magnesium, mercury, mica (sheet), molybdenum, nickel, perlite, phosphate, platinumgroup metals, potash, pumice, rare-earth metals, salt, silicon, silver, sulfur, tin, titanium, and zinc. A recurrent theme of this report is that mineral resources are associated with large-scale geologic processes that reoccur in time and space. The geologic distribution of mineral resources is intimately related to the geologic history of host rocks and structures. Increased knowledge about the geologic fabric around deposits and the processes that control the regional and local distribution of mineral resources will lead to improvement in predicting the location of new deposits.

\section{Introduction}

\section{Purpose of Report}

The main purposes of this report are to summarize the geologic setting of Greenland,

Europe, Russia, and Northern Central Asia (hereafter called the study area), and to provide a useful summary about the distribution of mineral resources, both discovered (in mines, deposits that have 
been explored, and prospects), and undiscovered (those that have yet to be found). This regional report is one of a series that summarizes current knowledge of the world's nonfuel mineral resources. These reports are designed to provide the non-earth scientist with information about the major known mineral commodities, their locations, and their general geologic setting. The reports are organized by the five regions shown in figure 1 . Additional information, such as production statistics, economic factors that affect the mineral industries of the region, and historical information, is available in U. S. Geological Survey (U.S.G.S.) publications such as the annual Minerals Yearbook and the Mineral Commodity Summaries (U.S. Geological Survey, 2004; available at http://minerals.usgs.gov/minerals) and through the detailed references provided at the end of this report. In addition, a brief overview of the potential for undiscovered mineral resources is included in this report. The data in this report are compiled mainly from published English sources, as cited in the text. An excellent world atlas of geology and mineral deposits was published by Derry (1980). For simplicity in this study, the term mineral deposit (or deposit) includes active and extinct mines, deposits that have been explored, and prospects, and the term mineral resource includes both discovered or known deposits and undiscovered deposits.

The data in this report are part the ongoing U.S.G.S.-led international Global Mineral Resource Assessment Project that is compiling and interpreting data on identified and undiscovered nonfuel mineral resources of the world at a scale of 1:1,000,000 (Briskey and others, 2001, 2002). The goal of this large, international collaborative study is to evaluate the global endowment of both identified and undiscovered nonfuel mineral resources in order to delineate areas of the world that are geologically permissive for the occurrence of undiscovered selected nonfuel mineral resources, together with estimates of the quantity and quality of the resources. This goal is important because a nation's endowment of nonfuel mineral resources, relative to the world's endowment, is a fundamental consideration in decisions related to a nation's economic and environmental well being and security. Knowledge of the worldwide abundance, distribution, and general geologic setting of mineral commodities provides a framework within which a nation can make decisions about economic development of its own resources, and the economic and environmental consequences of those decisions, in a global perspective.

\section{Importance of the Study Area for Mineral Resources}

In terms of production of metallic commodities and industrial minerals in 2004, the most recent year for which data are available from the U.S. Geological Survey (2005), Greenland, the countries comprising Europe and Northern Central Asia, and Russia were major or moderate producers of aluminum, antimony, arsenic, asbestos, barite, bentonite boron, chromium, cobalt, copper, diamond, diatomite, feldspar, fluorspar, gemstones, gold, graphite, gypsum indium, iron ore, iron ore, kaolin, kyanite, lead, lithium, magnesium, mercury, mica (sheet), molybdenum, nickel, perlite, phosphate, platinum-group metals, potash, pumice, rare-earth metals, salt, silicon, silver, sulfur, tin, titanium, and zinc (table 1). Lesser commodities not covered in this report include beryllium, bismuth, bromine, cesium, columbium, gallium, garnet, germanium, helium, iodine, kyanite, rhenium, rubidium, sand and gravel, scandium, selenium, soda ash, stone, tantalum, tellurium, thallium, thorium, vanadium, yttrium, and zirconium. Data on these commodities are available in the report by the U.S. Geological Survey (2004).

The distribution of mineral deposits in the region (Greenland, Europe, Russia, and Northern Central Asia) depends to a high degree on host rock geology. Different kinds of mineral deposits occur in different geologic settings; some minerals are formed within mountains and are related to the crystallization of molten rock, some are precipitated on the bottom of the ocean, and some only become economically important if they are concentrated by tropical weathering. This large region 
has great geologic diversity. Throughout geologic time, mountains were eroded and became ocean basins, continents collided and pushed up new mountains, and even the belt of tropical weathering associated with the equator has shifted its position around the globe, including the region of this report.

The United States does not produce enough of many mineral commodities to supply all of its current domestic demand, and it relies on imports to satisfy these needs. In 2004, the United States imported 100 percent of its arsenic, asbestos, bauxite and alumina, fluorspar, graphite, indium, manganese, industrial quartz crystal, rubidium, and strontium from sources that include countries in this region (U.S. Geological Survey, 2005). Although the region (Greenland, Europe, Russia, and Northern Central Asia) is rich in mineral resources (both identified and undiscovered), increasing concerns about the environmental and societal impacts of minerals development in the region are increasingly affecting the progress of new exploration and development activities.

\section{Region Covered by Report}

This study area for this report covers the region of Greenland, Europe, Russia, and Northern Central Asia and ranges in latitude from about $35^{\circ}$ to $85^{\circ}$ north in latitude, and from about $65^{\circ}$ to $180^{\circ}$ east and from $180^{\circ}$ to $170^{\circ}$ west in longitude (fig. 2). This region includes the countries of Albania, Armenia, Austria, Azerbaijan, Belarus, Belgium, Bosnia and Herzegovina, Bulgaria, Croatia, Czech Republic, Cyprus, Denmark (including Greenland), Estonia, Finland, France, Georgia, Germany, Greece, Hungary, Iceland, Ireland, Italy, Kyrgyzstan, Latvia, Lithuania, Luxembourg, Macedonia, Malta, Moldova, Monaco, Montenegro, Netherlands, Norway, Poland, Portugal, Romania, Russia, Serbia, Slovakia, Slovenia, Spain, Sweden, Switzerland, Tajikistan, Turkmenistan, Ukraine, United Kingdom, and Uzbekistan (fig. 2).

The summaries of regional geology and mineral resources for the region of the study area are divided into the following geographic groups of countries: Greenland and Iceland; Western Europe (Austria, Belgium, Cyprus, Denmark, France, Ireland, Italy, Luxembourg, Malta, Monaco, Netherlands, Norway, Poland, Portugal, Spain, Sweden, Switzerland, United Kingdom); Eastern Europe (Albania, Bosnia and Herzegovina, Bulgaria, Croatia, Czech Republic, Estonia, Greece, Hungary, Latvia, Lithuania, Macedonia, Moldova, Montenegro, Romania, Serbia, Slovakia, Slovenia); Belarus and Ukraine; Russia; and Northern Central Asia (Armenia, Azerbaijan, Georgia, Kyrgyzstan, Tajikistan, Turkmenistan, Uzbekistan) (fig. 2).

\section{Overview of Geologic and Tectonic History}

\section{Introduction}

The geologic evolution of the study area is recorded in a complex suites of rocks that range in age from some of the oldest found on Earth to the present. A wide age range of rocks occur on the earth's surface: The ages of the older rocks are grouped into the Archean Eon - before 2,500 million years ago, or the Proterozoic Eon - between 2,500 and 540 million years ago. The ages of younger rocks are grouped into: the Paleozoic Era - between 540 and 250 million years ago; the Mesozoic Era - between 250 and 65 million years ago; and the Cenozoic Era - between 65 million years ago and the present. The Earth is estimated to be about 4.5 billion (4,500 million) years old. A standard international geologic time scale is available from Remane (1998).

Rocks record the conditions of their formation and subsequent evolution, such as the accumulation of sediments in ancient oceans that form shale, limestone, or sandstone. Changing of these sedimentary rocks may occur through deep burial under conditions of high heat and pressure, 
resulting in the formation of metamorphic rocks (e.g., shale into slate or limestone into marble). Metamorphism may be associated with mountain building and with the melting and intrusion (emplacement) of igneous (semi-molten rock called magma) rocks and volcanism at the surface. These processes lead to a new cycle of erosion and deposition of sediments in the ocean or in basins on land.

Specific types and textures of rocks are formed by different geologic processes, and likewise, specific types of mineral deposits are associated with different rocks and processes. Knowledge of the distribution in time and space of rock types, mineral occurrences, and other geologic information allow mineral resource specialists to reasonably estimate the likely location and size of undiscovered mineral resources in a region.

The geologic evolution of the Earth is expressed in many ways, including elevation, subsurface layers, and by geologic processes. One expression is the variation of elevation of the land surface, or topography. Figure 3 is a digital elevation map of the surface of Earth above sea level. Green shows relatively low-lying areas of the continents, brown shows the higher elevations of mountains. As illustrated in figure 3, the study area contains extremely varied topography climate, geologic environments, and rock types.

Another expression of the geologic evolution of the Earth is a display of the three main layers of the earth that are analogus to an egg (fig. 4, Kious and Tilling, 1996). The crust, or outermost layer (like the shell of the egg), is rigid and very thin compared with the other two layers. It ranges in thickness from 0 to $100 \mathrm{~km}$. Below the crust is the mantle (like the white of the egg) that is a dense, hot layer of semi-solid rock approximately 2,900 km thick. At the center of the Earth is the core (like the yoke of the egg) that is composed of both solid and liquid iron-nickel alloy. Other major layers in the earth are the lithosphere (the crust and upper-most solid mantle) and the asthenosphere (a zone in the upper mantle that consists of several hundred kilometers of deformable rock).

Another expression of the geologic evolution of the earth is the major geologic units. The crust and solid outermost part of the mantle compose the lithosphere that is broken into a dozen or more large and small tectonic plates that are moving relative to one another as they ride on top of hotter, more mobile mantle material (fig. 5). (The term tectonic relates to the cause or result of structural deformation of the earth's crust.) A tectonic plate is a massive, irregularly shaped slab of solid rock, composed generally of both continental or oceanic lithosphere. Plates can vary greatly in size, from a few hundred to several thousands of kilometers across. Plate thickness also varies greatly, ranging from less than $15 \mathrm{~km}$ for young oceanic plates to about $200 \mathrm{~km}$ or more for ancient, continental plates (e.g., the interior parts of of the Eurasian continent). These plates move relative to each other, sometimes spreading apart (divergent plate boundary), sometimes colliding with each other (convergent plate boundary), sometimes scraping past each other, and different types of mineral deposits formed with the different processes. Figure 5 illustrates these major tectonic processes that result in the formation of major types of mineral deposits. Some of the major processes are divergent plate boundaries with an oceanic spreading center, a convergent plate boundary (orogen) with a subduction (major thrust fault) zone, continental igneous arc with a volcano, lithosphere, asthenosphere, and various types of mineral deposits that form in specific tectonic settings.

For the below summaries of geologic and tectonic history of the study area, the reader should refer to fig. 3 for regional geographic names. 


\section{Greenland}

Greenland is the largest island in the world (figs. 3, 6). Approximately 80 percent of the island is covered by an ice sheet (fig. 6) that ranges up to $3.4 \mathrm{~km}$ thick. However, an ice free strip of land up to $300 \mathrm{~km}$ wide occurs along the coast. Prominent geologic features of Greenland include an Archean craton (a large portion of an Archean and Proterozoic continental plate) in southern Greenland (gray units, fig. 6), Early Proterozoic deformational belts (orogens) (blue units, fig. 6), Paleozoic deformational belts (pink units, fig 6) in northern and eastern Greenland, and large areas in western and eastern Greenland covered by Tertiary large-area (flood) basalt (yellow units, fig 6) related to an Icelandic flood basalt (Saemundsson, 1979; Henriksen and others, 2000; Hoffman, 1989; and Escher and Watt, 1976).

About half of the ice-free area of Greenland consists of Archean and Proterozoic age craton (fig. 6). Archean rocks are exposed on the coasts of southwest and southeast Greenland (Nain province, gray units, fig. 6) (Hoffman, 1989). Areas within this province contain some of the oldest rocks on Earth (3.8 to 3.6 billion years ago). The Nain province formed by the accretion of several terranes (fault-bounded fragments or mini-plates) that had independent histories before accretion (juxtaposition) between about 2.75 and 2.65 billion years ago. Mineral resources associated with the Nain province include the Isua iron deposits and chrome deposits of the Fiskaenasset area (Nielsen, 1976). North of the Nain province are the Proterozoic Nagssugtoqidian (1.87 billion years) and the Proterozoic Rinkian (1.90 to 1.84 billion years) deformational belts (blue units, fig. 6). The Nagssugtoqidian and Rinkian deformational belts are extensions of the Torngat and Foxe deformational belts in Canada, respectively. Hoffman (1989) suggests that a small Archean province, the Burwell, may lie between the Nagssugtoqidian and Rinkian deformational belts. Deformed Archean rocks of the Rae province are inferred to lie north of the Rinkian deformational belt and extend to the Devonian Ellesmerian deformational belt along the northern coast of Greenland (gray units, fig. 6) (Hoffman, 1989). Exposures of other early Proterozoic deformational belts (blue units, fig. 6), occur in northwestern Greenland (the Inglefield deformational belt) and eastern Greenland (involving cratonal rocks now part of the younger (early to middle Paleozoic) Caledonian deformational belt. The Proterozoic deformational belt in eastern Greenland may be related to the Grenville deformational belt in North America. The southeast margin of the Nain province is defined by the Ketillidian deformational belt (about 1.80 billion year age) of southern Greenland.

Later in the Proterozoic and throughout the Phanerozoic, sedimentary basins formed (pink units, fig. 6), notably in North and northeastern Greenland (Henriksen and others, 2000). In places, layered sequences of sedimentary rocks can be up to 10-15 km thick. A basin with more than $2 \mathrm{~km}$ of Middle Proterozoic sedimentary rocks is exposed in northeast Greenland. These sedimentary rocks are intruded by mafic (magnesium-rich and iron-rich) sills (1.23 billion year age) and are overlain by up to 1.3 kilometers of related flood basalts (Hoffman, 1989). The Thule Basin in northwest Greenland has at least $6 \mathrm{~km}$ of sedimentary and basalt volcanic rock that accumulated between 1.27 billion and 650 million years ago. Another $16 \mathrm{~km}$ of sedimentary rocks were deposited in a major sedimentary basin in East and Northeast Greenland between 950 and 610 million years ago.

In southern Greenland, about $3.4 \mathrm{~km}$ of sandstones and lavas accumulated in a continental rift (divergent tectonic event in a continent, e.g., fig. 5) called the Gardar Province (Henriksen and others, 2000). This province forms in zone extending $180 \mathrm{~km}$ east-west and $80 \mathrm{~km}$ north-south within the Ketillidian deformational belt (orogen). Fourteen potassium- and sodium-rich (alkaline) intrusive complexes, ranging from 1.30 to 1.12 billion years age, were emplaced during this rift (divergent tectonic event, e.g., fig. 5) (Henriksen and others, 2000; Wooley, 1987). Some of these 
intrusions have subeconomic concentrations of zirconium, uranium, rare-earth metals, and phosphate (Nielsen, 1976; Kirkham and Rafer, 2003; and Secher, 2002).

The Paleozoic Franklinian Basin extends $2000 \mathrm{~km}$ from the Canadian Arctic Islands to eastern North Greenland (pink units, fig. 6) (Henriksen and others, 2000). Sedimentation in this basin started in the latest Precambrian and was ended by the Devonian Ellesmerian deformational belt. The shelf section (shallow continental-margin sedimentary rock sequence) of the Franklinian basin deposited on the Precambrian craton is up to $3 \mathrm{~km}$ thick; sediments deposited in the northern deep-water trough are about 8 kilometers thick. The shelf-trough boundary was probably controlled by faults. The sedimentary exhalative (so called SEDEX, e.g., fig. 5) Citronen Fjord zinc and lead deposit formed during deposition of the Franklinian basin (Van der Stijl and Mosher, 1998, Henriksen and others, 2000). Approximately $4 \mathrm{~km}$ of early Paleozoic (Cambrian and Ordovician) age rocks were deposited in East Greenland before sedimentation was ended by the Silurian Caledonian deformational belt. Both the Ellesmerian and Caledonian deformational belts (orogens) are related to convergence and collision of tectonic plates that formed the supercontinent Pangea (Condie, 1997).

Late Paleozoic and Mesozoic sedimentary basins (green units, fig. 6) developed in northern, eastern, and western Greenland are closely related to continental break-up of the supercontinent Pangea (Henriksen and others, 2000; Condie, 1997). North-south trending sedimentary basins, such as the Jameson Land basin, developed in east Greenland. Cretaceous to Tertiary sediments were deposited in the Nuussuaq basin in west Greenland. These basins formed during periods of faulting and rifting that ultimately culminated with the separation of Greenland from North America in the Late Cretaceous and from Europe in the late Paleocene.

With the opening of the North Atlantic Ocean, Tertiary volcanic rocks, dikes, and intrusions related to the Icelandic hot spot formed in east and west Greenland (yellow units, fig. 6) (Henriksen and others, 2000). In west Greenland, between 4 and $10 \mathrm{~km}$ of basaltic volcanic rocks occur. Basaltic volcanic rocks (up to $2.5 \mathrm{~km}$ thick) cover $65,000 \mathrm{~km} 2$ in east Greenland. Numerous intrusions related to hot-spot magmatism are exposed in the coastal region of east Greenland. The intrusions show a wide range of compositions. The Skaergaard intrusion (Early Cenozoic or about 55 million year age) is a layered gabbro (magnesium- and iron-rich or mafic) intrusion that has mineralized rock units enriched in palladium and gold. In contrast, the Werner Bjerge complex is made up of potassium- and sodium-rich (alkaline) granitic rock (Nielsen, 1976). Molybdenum mineralization is associated with these rocks (Nielsen, 1976; Kirkham and Raefer, 2003).

\section{Iceland}

In the terms of global tectonics, Iceland is a hot spot located along a divergent plate boundary (rift, e.g., fig. 5) (Steinthorsson and Thorarinsson, 2001). All the major features of Iceland geology (yellow units, fig. 6), including the topographic high, the mafic and silicic volcanic rocks, the central (transverse) ridge, and the progression in age from the active central rift of Iceland to the Tertiary basalts of eastern Greenland (65 million years age) and Britain (45 to 50 million years age), are interpreted as forming above a hotspot (e.g., fig. 5) (mantle plume beneath a spreading center) along an oceanic ridge in the Mid-Atlantic.

Volcanism and crustal spreading along the central rift zones occurs in discrete fissure swarms straddling the plate boundary in an en echelon array (Steinthorsson and Thorarinsson, 2001). The swarms are 10 to $100 \mathrm{~km}$ long, and display extensional tectonic features such as open fissures, graben structures (fault-bounded basin), and rows of volcanic craters at the surface, and dikes and normal (extensional) faults at deeper levels. The central, most active part of each system, 
overlying the plate boundary, is frequently the site of a central volcano, characterized by a range of basalt and rhyolite lava flows, and a high-temperature geothermal system.

The exposed volcanic pile consists mainly of basalt lava flows with lesser silicic and intermediate rocks (Jakobsson, 1979). In a typical Tertiary section, volcanogenic sedimentary rocks constitute a minor part of the succession; in the Quaternary areas, however, they constitute a greater part of the succession because of glaciation interspersed with volcanism and because of erosion. The silicic rocks occur mainly in volcanic centers. The predominantly volcanic rock formations of Iceland range in age back to about 15 million years age. During all that time, volcanism appears to have continued uninterrupted, and with largely uniform vigor, in the rift zones.

The rocks are conventionally divided into four stratigraphic units whose boundaries which are based mainly on studies of relative succession of units, stadies of ancient paleomagnetic orientations (analogus to a frozen compass in each rock unit), and radiometric (absolute age) dating (Steinthorsson and Thorarinsson, 2001). The Tertiary units, covering some 50,000 km2, include the plateau basalts of all but southern Iceland and are well exposed due to glacial erosion. The Pliocene-Pleistocene units cover about 25,000 km2 and occupy wide belts intermediate between the Tertiary areas and the young volcanic zones. The upper Pleistocene Series occurs in about the same area as the young neovolcanic zones and measures about $30,000 \mathrm{~km} 2$. Postglacial formations in Iceland consist of lava flows and volcanic ash and debris deposits, glacial clay, unconsolidated marine clay, glacial and lake sediments, and soil formed after deglaciation of the land area. Three main types of volcanoes have been active in the Holocene: shield volcanoes, crater rows, and central volcanoes.

\section{Europe}

\section{Introduction}

The literature of European geology is compiled in hundreds of regional journals, survey reports and academic theses that are written in many languages. However, several major references on the regional geology and mineral deposits of Europe are published. Among them are Commission for the Geological Map of the World (1968-1982, 1973), Ager (1980) Ziegler (1990), Blundell and others (1992), Windley (1995), Schwan (1997, 2001), and Moores and Fairbridge (1997).

\section{Major Geologic and Tectonic Provinces}

Northern and northwestern Europe is adjacent to the oceanic crustal areas of the Arctic Ocean and Norwegian and the North Atlantic Ocean (fig. 3). The western border is the continental slope along the eastern margin of the Atlantic Ocean (fig. 3), and the eastern margin is the eastern limit Archean shield rocks (ancient continental crust) (gray and blue bunits, fig. 6) and overlying Paleozoic and Mesozoic sedimentary units of the Northern European Plain, the European Russia Plain, and The Steppes (figs. 3, pink and green units, fig. 6) (Schwan, 1997, 2001). This region is separated from Asia by late Paleozoic deformational (accretionary) belt of the Urals Mountains (fig 3 ). Southern Europe is bordered by the Paleozoic through Cenozoic rocks (pink, green, and yellow units, fig. 6) that extend northward from northern Africa. In Italy is the active Appennines deformational belt (figs. 3,6 ) that consists of a modern continental-margin igneous arc containing a chain of late Cenozoic and modern active volcanoes (yellow units, fig. 6), and an eastward and outboard subduction zone (e.g., fig. 5) where the Adriatic Sea to the east is being thrust under the continental rock units of Italy to the west (Doglioni and Flores, 2001). 


\section{Major Sedimentary Basins}

In addition to extensive Archean and Proterozoic shields in central and northern Europe (fig. 6), various major, younger sedimentary basins formed at various times during the geologic evolution of Europe. Seas formed in these basins giving rise in some areas of thick marine sedimentary rock and lesser volcanic rock of Paleozoic, Mesozoic, and Cenozoic age (pink, green, and yellow units, fig 6). For instance, in European Russia, west of the Urals Mountains, sedimentary rocks that comprise the European Russian Plain (fig. 3) consist of a thin veneer of sediment was deposited in a middle and late Paleozoic sea (pink units, fig. 6) (Schwan, 2001). The middle Paleozoic deposits only partially cover the platform, but late Paleozoic shallow water deposits cover nearly the entire sedimentary platform.

The early Paleozoic through late Cenozoic sedimentary units, that overlie the underlying Archean and Proterozoic craton of the European Russian Plain (fig. 3), formed during repeated, horizontal marine and terrestrial sediments in transgressions (advance and rising) of continentalmargin seas during the Paleozoic, Mesozoic, and Cenozoic. The ocean transgressions and regressions (retreat and lowering) occurred during broad deformations that formed basins and domes with very gentle slopes. Locally, some major fault-bounded basins (grabens) formed and resulted in strong subsidence and sedimentation and marginal eruption of basalt.

\section{Urals Mountains}

The eastern margin of the European continent, consisting of the European Russia Plain and The Steppes (fig. 3), is marked by the Urals Mountains that contain a major deformational (accretionary) belt composed of a series of Proterozoic and early to middle Paleozoic oceanic crust, island arc, continental margin platform fragments or terranes (blue and pink units, fig. 6) (Zonenshain and others, 1990; Schwan, 2001). The Urals Mountain belt is interpreted as forming during collision of Archean and Proterozoic shield (continental) fragments underlying the Eastern Europe and European Russian and Siberian platforms and underlying Archean and Proterozoic shields (cratons), with intervening oceanic crust and island arcs (Zonenshain and others, 1990). The major collision occurred in about the late Paleozoic to early Mesozoic (Carboniferous to Early Triassic).

The following four major geologic units comprise the Urals Mountains (Zonenshain and others, 1990); however, the units are too narrow to depict on fig. 6. (1) The oldest unit is the Archean and Proterozoic Pre-Urals Mountains Complex that contains fragments of basement of former continents and microcontinents, large blocks of gneiss, granite, and schist, and oceanic crust and mantle (ophiolite). (2) An external Urals Mountains unit consists of early to late Paleozoic continental shelf and slope sedimentary units. (3) An internal Urals Mountains unit consists of early to late Paleozoic oceanic crust and island arc fragments or terranes, including mafic (magnesiumand iron-rich) and ultramafic units that are intruded by Late Carboniferous to early Permian granite. (4) The youngest unit is overlapping Mesozoic and Cenozoic sedimentary rock and local Triassic basalt.

\section{Siberia and the Russian Far East}

East of the Urals Mountains in Russia is a huge area with a large diversity of rock units. The most extensive unit is the the North Asian (Siberian) Craton and overlying Paleozoic through Cenozoic sedimentary units blue, pink, green, and yellow units, fig. 6) that occur in the Western Siberia Plain, the Central Sierian Plateau, Verkhoyansk Mountains, Chersky Range, TransBaikal region, and Stanovoy Range (fig. 3). Extensive Cenozoic sedimentary rocks, that overlie older 
Paleozoic and Mesozoic sedimentary units and older shield (cratonal) units, occur in the Western Siberia Plain (fig. 6). To east and south, in the Kolyma and Koryak Mountains, the Khingan Basin, and the Sikhote-Alin Mountains (fig. 3) are fault-bounded fragments (terranes or mini-plates) of Mesozoic, and Cenozoic island arcs, oceanic, and ancient subduction (thrust) zone units (e.g., fig. 5) (mainly green and yellow units, fig. 6). Along the eastern margin of Russia on the Kamchatka Peninsula and Kurile Islands (fig. 3) is the active Kamchatka and Kurile continental-margin volcanic arc (yellow units, fig. 6) (Zonenshain and others, 1990; Nokleberg and others, 1994, 1997; Khain and Nikishin, 2001; Parfenov and others, 2003, 2004). In the area south of the TransBaikal Region (fig. 3) is a collage of middle Paleozoic through early Mesozoic island arc and oceanic fragments (terranes) and related major thrust (subduction) zone units (mainly pink units, fig. 6).

In addition in the northern Central Siberian Plateau (fig. 3) is the major Tunguska basin that is filled with the well-known and extensive late Paleozoic and early Mesozoic flood basalts and related magnesium- and iron-rich (mafic and ultramafic) plutonic rocks (mainly pink and green units, fig. 6). The flood basalts and related plutonic rocks are interpreted as forming over a major continental plume. Also intruding Central Siberian Plateau are major and widespread intraplate granite (alkaline or sodium- and potassium-rich) plutons of Proterozoic, and early and middle Paleozoic age.

\section{Northern Central Asia}

\section{Altay-Sayan Mountains of Northern Central Asia}

The Altay Mountains occur south of the Western Siberia Plain and the Kazakh Uplands (fig. 3) (Zonenshain and others, 1990). Growth, through continued creation and accretion of magmatic arcs, continued through the Paleozoic, and terminated with the collision of the Atay Mountains magmatic arc collage (mainly pink units, fig. 3) and the Archean shield units of western Russia and eastern Europe along the major fault zone (suture) in the Urals Mountains (Şengör and Natal'in, 1996; Yakubchuk, 1997; Yakubchuk and others, 2001; 2002). The magmatic arcs of the Altay Mountains have been collectively folded to form a large crustal-scale fold (Kazakh orocline in the Kazakh Mountains). The Altay Mountains consist of three major igneous arcs (Kipchak, TuvalMongol, and Mugodzhar-Rudny-Altai) that range in age from the late Proterozoic to early Paleozoic. In the Middle Paleozoic, the Kipchak and Tuval-Mongol igneous arcs collided to form the Kazakh-Mongol igneous arc. Each arc is separated by a major fault (suture zone) that locally contain mafic (magnesium- and iron-rich) and ultramafic oceanic crustal units (ophiolites) that were derived from ancient seafloor.

\section{Mesozoic-Cenozoic Sedimentary Basins}

Major Mesozoic and Cenozoic sedimentary basins rocks occur in areas of the Turan Lowland, Aral Sea, and Caspian Sea (fig. 3) (green and yellow units, fig. 6) (Zonenshain and others, 1990). Many of these basins are floored by basaltic volcanic rock that is interpreted as part of oceanic crust. The sedimentary basins contain thick accumulations of terriginous material as well as marine and lacustrine sediments.

\section{Caucasus Mountains}

The Caucasus Mountains region (fig. 3) contain a complex suite of Mesozoic island arc, arc basin, and late Mesozoic and Cenozoic collisional and related volcanic rocks (pink and green units, fig. 6) that formed along the southern margin of the Eastern European Archean shield (Khain and 
Koronovsky, 1997). The Mesozoic island arc and inter-arc basins formed at the same time as when the Mesozoic and Cenozoic sedimentary basins were forming in the Turan Lowland, Aral Sea, and Caspian Sea areas. The collisional volcanic rocks and granitoid intrusions formed during accretion in the Cenozoic, and the region remains seismically active today. The island arcs and associated basins, trenches, and faults are part of the Tethys deformational (orogenic) belt that extended from Eastern Europe to southeastern Asia.

\section{Principal Commodities and Mineral Deposits}

Deposits of metals and industrial minerals have formed throughout the geologic history of the study area and form a highly diverse assemblage of commodities and mineral deposit types in the region (tables 2A, 2B; figs. 7, 8). Older rocks commonly are deformed and recrystallized and are associated with a different assemblage of mineral deposits than are younger rocks. The old Archean and Proterozoic rocks (shields) that compose the cratons contain large iron and nickelcopper deposits. Gold deposits occur in rocks of many types and ages. However, some deposits, called placer deposits, are concentrated by running water and thus are generally associated with young stream and river channels or sometimes with older fossil channels.

Mineral deposits also vary by geologic environment as well as age. For instance, the various accreted (fault-bounded) fragments (terranes) in the Russian Far East contain several prominent sub-parallel belts of mineral deposits of mainly Mesozoic and Cenozoic age. Close to the Pacific coast is a copper belt, followed inward by polymetallic (usually lead and zinc) and tin belts, each belt containing deposits of different ages and deposit types.

Tables $2 \mathrm{~A}$ and $2 \mathrm{~B}$ provide important non-fuel mineral resource data for more than 800 metallic and non-metallic (industrial) mineral deposits for the region of Greenland, Europe, Russia, and Northern Central Asia. Tables 2A, 2B are compilations of the major commodities and the mines, deposits, and prospects from which they have been or may be produced in the future in the region. In addition to providing important basic data on non-fuel mineral resources for the region, these tables illustrate the importance and diversity of these mineral deposits and their geologic environments.

Table 3 briefly describes how the deposits identified in table 2 are classified by type, and how the deposits formed, and gives examples of these deposits. The principal mineral deposits are shown by location and principal commodity with a generalized geologic base in figures 7 and 8 . Simplified geologic settings for the major mineral deposit models are illustrated in figure 5. Comparison of these features with the generalized geologic and tectonic base (fig. 6) shows a strong correlation between geology, commodity, deposit type, and mountain-building (tectonic) processes. Mineral deposits of a particular commodity commonly form in similar ways throughout time and space, so particular geologic features can be used to find mineral deposits and then to classify them into various types.

\section{Metals}

Metals are concentrated to form mineral deposits in the Earth's crust by a variety of processes. If the metals are concentrated enough to make their extraction economical, the concentration is called an ore deposit. If not economic, the concentration is called either a deposit that has been explored, or a prospect. Mineral deposits (mines, deposits that have been explored, and prospects) form as the result of a combination of factors, including the availability of metals in a source area, a means to transport the metals, and a mechanism to concentrate and deposit them. Similarities in the geological characteristics of the source areas, and in the transportation and concentration processes, result in similar features among the mineral deposits. These features 
permit mineral deposits to be grouped, described, measured, and classified into mineral deposit models or types (e.g., tables 2,3 ). The mineral deposit models allow predictions to be made of the abundance and location of undiscovered deposits. The models present the features that a group of mineral deposits have in common and that are essential to form a concentration of metals. A collection of mineral deposit models published by Cox and Singer (1986) is used to organize deposits by type in this report. Selected descriptive models are used to illustrate the diagnostic features that deposits have in common.

The following sections in the report summarized the use, nature of occurrence, and location of significant deposits for the region of Greenland, Europe, Russia, and Northern Central Asia, in this section of the report for metals, and in a subsequent section for industrial minerals (non metals). The data for the below tables on 2003 or 2004 (for world mine production, reserves, and reserve base) for the study area, and for the leading global producers are from the Mineral Commodity Summaries by the U.S. Geological Survey $(2004,2005)$. Country-specific commodity data are available on the Internet/Web at http://minerals.usgs.gov/minerals/pubs/country/.

In the below sections, the term reserve base is defined as that part of an identified resource that meets specified minimum physical and chemical criteria related to current mining and production practices, including those for grade, quality, thickness, and depth. Commodities that are part of the reserve base that can be economically produced (U.S. Geological Survey, 2004). In the below sections, data on both the leading producer of a particular commodity are provided along with data for countries in the region (Greenland, Europe, Russia, and Northern and Central Asia).

\section{Aluminum}

Aluminum is a silver-white, very light but strong metal. Because aluminum is ductile, it can be drawn into wires or pressed into sheets or foil. Its light weight and resistance to corrosion make it ideal for use in aircraft, automobiles, beverage containers, and buildings. Aluminum makes up 8 percent of the Earth's crust; only silicon and oxygen are more plentiful. Although aluminum is a common element in many rocks, it is economical to mine and process only in rocks where the aluminum has been concentrated. Bauxite, an impure mixture of highly-aluminous minerals, is the principal raw material used to make aluminum.

Bauxite occurs mainly in surficial deposits that can form by weathering of any aluminumbearing rock in an area that has a tropical climate with alternating wet and dry seasons and a terrain with high relief and good drainage, all of which promote chemical leaching that results in concentration of aluminum (fig. 9). A similar concentration process also occurs for nickel, iron, and chromium for what are named iron, nickel, and (or) chromium laterite deposits (fig. 9). Most major bauxite deposits formed originally in tropical regions relatively near the equator. Because of plate teconic migrations, some bauxite deposits occur in the study area(Harben and Kužvart, 1996). Many of these deposits formed during the Cenozoic.

Compared to Australia, which was the principal mining producer of bauxite in 2004, the countries in the study area produced only a small proportion of global production of bauxite (table 4). Russia, as the largest producer in the region, produced 2.6 percent of world production in 2003. Other countries in the region produced a small proportion, less than three percent. The two countries that accounted for most of the production in Europe were Greece and Hungary in that order (U.S. Geological Survey, 2005). These countries mine bauxite from surficial deposits formed mainly by weathering of aluminum-rich rock, such as granite. Bauxite deposits also occur in hydrothermal, igneous, metamorphic, and sedimentary rocks. Known global resources of bauxite are estimated to be 55 to 75 billion tonnes, located primarily in South America (33 percent), Africa 
(27 percent), Asia (17 percent), Oceania (13 percent), and elsewhere (10 percent) (U.S. Geological Survey, 2004).

Table 4. Bauxite - data for 2003 for world mine production, reserves, and reserve base for the study area and for the leading global producer (U.S. Geological Survey, 2004).

\begin{tabular}{l|l|l|l|l}
\hline Country & $\begin{array}{l}\text { Percent of world production, } \\
2003\end{array}$ & $\begin{array}{l}\text { Rank of world } \\
\text { production }\end{array}$ & $\begin{array}{l}\text { Percent of world } \\
\text { reserves }\end{array}$ & $\begin{array}{l}\text { Percent of world reserve } \\
\text { base }\end{array}$ \\
\hline Russia & 2.6 & 9 & 0.9 & 0.8 \\
Australia & 38.1 & 1 & 18.9 & 26.3
\end{tabular}

About 17 major aluminum (bauxite) deposits occur in the study area (table 2A, fig. 7A). Some of the major deposits are as follows: Parnassos in Greece; Bakony District in Hungary; the Ajatskoe 1, Aktogajskoe, Bosaga, Koktauskoe, Krasnooktjabr'skoe, Kubasadyrskoe, Red October, Sar-Kol', Sokurkoj, Torgai, and Zapadno-Ubaganskoe in Kazakhstan; Dzhilinda (Mukhal'skoe), Iskinskoe (Askum), Kharlinskoye, Krasnaja, Shapochka, Sredne, and Timan in Russia, and the Oktjabr'skoe in Ukraine. Kazakhstan has large bauxite reserves that are mostly hosted in sedimentary karst deposits (MBendi World: Mining, 2004). The major deposits are the Torgai and Red October bauxite mines in the Kostanai region. Russia is the world's ninth largest bauxite producer, producing in the region five to six million tonnes of metal annually. Most of the country's bauxite has been produced from the Northern Urals Mountains, which produced more than 80 percent of Russia's total. The Urals Mountains are reported to contain nearly 30 percent of Russia's explored bauxite reserves where mjaor new deposits occur in the southern part of Kola Peninsula.

\section{Antimony}

Antimony is a hard, brittle, silvery-gray semi-metal used principally for flame retardants. It also is used in ammunition and automotive batteries and as a decolorizing agent in glassmaking. It is present with gold and silver in certain hydrothermal-type mineral deposits (fig. 5). Antimony deposits contain mainly the mineral stibnite (antimony and sulfur). Compared to China, the major 2003 and 2004 producer of antimony, Russia and Tajikistan produced five percent of world production in 2003 (table 5). In 2004, production occurred from major mines in Bolivia, China, Mexico, Russia, and South Africa (U.S. Geological Survey, 2005).

Table 5. Antimony - data for 2003 for world mine production, reserves, and reserve base for the study area and for the leading global producer (U.S. Geological Survey, 2004).

\begin{tabular}{l|l|l|l|l}
\hline Country & $\begin{array}{l}\text { Percent of world production, } \\
\text { 2003 }\end{array}$ & $\begin{array}{l}\text { Rank of world } \\
\text { production }\end{array}$ & $\begin{array}{l}\text { Percent of world } \\
\text { reserves }\end{array}$ & $\begin{array}{l}\text { Percent of world reserve } \\
\text { base }\end{array}$ \\
\hline $\begin{array}{l}\text { Russia } \\
\text { (recoverable) }\end{array}$ & 3.2 & 3 & 19.8 & 9.5 \\
Tajikistan & 1.8 & & & \\
China & 88.0 & 4 & 2.8 & 3.8 \\
& & 1 & 44.8 & 61.4
\end{tabular}

In Greenland, Europe, Russia, and Northern Central Asia, some of the major antimony deposits where antimony is the principal commodity are the Amasijskoe in Armenia, the Zopkhito in Georgia, the Kadamdjai and Terekskoe in Kyrgyzstan, and the Jezhikrut in Tajikistan (table 2A, fig. 7A). Antimony from stibnite or (antimony and sulfur) occurs in several mineral deposits types, including hydrothermal, igneous, and sedimentary types. Kyrgyzstan has several large deposits near Nichkesu, which have estimated reserves of 100,000 tonnes. Other deposits at Aktyub and 
Savoyardy also contain significant reserves (MBendi World: Mining, 2004). The major antimony reserves in Russia in which antimony is the primary commodity are reported to occur in the Sakha (Yakutia) Republic.

\section{Arsenic}

Arsenic is a brittle, steel-gray metal that is used as a preservative for outdoor wood products, in fertilizers, herbicides, insecticides, ammunition, solders, storage batteries, and in semiconductors. Arsenic is derived mainly from the mineral arsenopyrite (arsenic, iron, and sulfur), realgar (arsenic and sulfur), and orpiment (arsenic and sulfur) that occur mainly in volcanogenic massive sulfide (hydrothermal) deposits in association with copper, lead, and zinc (fig. 10), and in granite-hosted copper deposits. Compared to China, the major 2003 and 2004 producer of arsenic, countries in the study area (Belgium, France, Kazakhstan, and Russia) produced about 13.8 percent of world production 2003 (table 6). World reserve base is estimated to be about 30 times annual world production (U.S. Geological Survey, 2005).

Table 6. Arsenic - data for 2003 for world mine production, reserves, and reserve base for the study area and for the leading global producer (U.S. Geological Survey, 2004).

\begin{tabular}{l|l|l}
\hline Country & Percent of world production, 2003 & Rank of world production \\
\hline Belguim & 2.6 & 5 \\
France & 2.6 & 5 \\
Kazakhstan & 4.3 & 4 \\
Russia & 4.3 & 4 \\
China & 47.1 & 1
\end{tabular}

In Greenland, Europe, Russia, and Northern Central Asia, the major arsenic deposits, where arsenic is the principal commodity, are the Uch-Imchek in Kyrgyzstan, and the Lukhumi and Tsana in Georgia (table 2A, fig. 7A). Arsenic from arsenopyrite (arsenic, iron, and sulfur) occurs in several mineral deposit types, including hydrothermal (fig. 10) and igneous. Arsenic also occurs in association with several other commodities, including copper, gold, lead, mercury, and zinc, and in igneous and hydrothermal mineral deposits types (table 2, fig. 8).

\section{Chromium}

Chromium is a hard, steel gray, lustrous metal that takes a high polish and is principally used as an alloy with steel for stainless steel and other specialty uses in which resistance to corrosion is important. Chromium is also used for plating of steel in areas where it is exposed to water, colored chemicals (such as yellow paint for highways), and refractories. The mineral chromite is the only ore of chromium and is a complex compound of the oxides of chromium, ferrous and ferric iron, magnesium and aluminum. Chromium occurs in masses and dissemination in stratiform iron- and magnesium-rich igneous bodies in association with nickel and platinum. In some regions, chrome deposits are locally associated with copper, nickel, and platinum deposits that form in mafic- and iron-rich (mafic) plutonic (subsurface) igneous bodies. Compared to South Africa, the major 2003 and 2004 producer of chromite Kazakhstan, the major producer in the study area, produced about 17.1 percent of world production in 2003 (table 7) (U.S. Geological Survey, $2004,2005)$. The world reserve base of chromium is estimated to be about $1,800,000,000$ tonnes. In 2003, the total chromite production was estimated at 14,000,000 tonnes. In 2003 and 2004, production occurred from major mines in India, Kazakhstan, and South Africa (U.S. Geological Survey, 2004, 2005). 
Table 7. Chromium - data for 2003 for world mine production, reserves, and reserve base for the study area and for the leading global producer (U.S. Geological Survey, 2004).

\begin{tabular}{l|l|l|l|l}
\hline Country & $\begin{array}{l}\text { Percent of world production, } \\
\text { 2003 }\end{array}$ & $\begin{array}{l}\text { Rank of world } \\
\text { production }\end{array}$ & $\begin{array}{l}\text { Percent of world } \\
\text { reserves }\end{array}$ & $\begin{array}{l}\text { Percent of world reserve } \\
\text { base }\end{array}$ \\
\hline Kazakhstan & 17.1 & 2 & 35.8 & 26.1 \\
South & 46.4 & 1 & 12.3 & 11.1 \\
Africa & & & &
\end{tabular}

Chromium from chromite or (chromium, iron, and oxygen) occurs in mainly magnesiumand iron-rich (mafic and ultramafic) igneous rocks and to a lesser extent in surficial (placer) deposit types (table 2A, fig. 7A). The largest chrome deposits in the world, as in the Bushveld complex in South Africa, occur in extremely large layered intrusions in which layers of chrome-bearing minerals, and also associated PGE (platinum group elements), copper, and nickel minerals occur with other silica-rich minerals. The layers are interpreted as forming during crystal settling or during deposition of igneous mud-flow deposits on the floor of the magma chamber. The larger layered mafic and ultramafic intrusions are in cratons in continental plates. However, smaller podiform chromite lenses and masses for in mafic (magnesium- and iron-rich) and ultramafic igneous intrusions in thick volcanic sequences in back-arc basins and on the seafloor as oceanic crust (ophiolite) during oceanic rifting. During closure of back-arc and oceanic basins and amalgamation and collision of island arcs and continental terranes, the mafic-ultramafic rocks are thrust onto colliding terranes or continental margins along major fault (suture) zone. Consequently, many chromium, copper, nickel, and PGE deposits occur along major collisional fault (suture) zones. Chromite along with nickel also occurs in surficial laterites that overlie highly-weathered mafic and ultramafic igneous rocks.

Ten major chromite deposits occur in the study area (table 2A, fig. 7A). Some of the major chrome deposits, where chromite is the principal commodity, are as follows: Bulqiza in Albania; Kemi in Finland; Fiskenaesset in Greenland; 20 Let KazSSR, Almaz-Zhemchuzhina, the Donskoy group of deposits in Kazakhstan; and the Solovyevskii Log (surficial type) in Russia (table 2A, fig. 7A).

Two major chromite deposits in the study area are the Fiskenaesset in western Greenland, and the Almaz-Zhemchuzhina in the southern Urals Mountains of Kazakhstan, and the Kemi area of Northern Finland, and in Albania. The deposits in Kazakhstan and Albania are are in oceanic crust (ophiolite) and the Kemi deposit is in a layered intrusion. Other deposits occur in the central and northern part of the Urals Mountains in Russia and in Greenland, but are not mined with the exception of a deposit in the central Urals Mountains of Russia. The Fiskenaesset deposit consists of a feldspar-rich igneous rock (anorthosite) that forms a single stratiform intrusion that is about 2.85 billion years old (Henriksen and others, 2000). The intrusion is about $200 \mathrm{~km}$ long and up to $380 \mathrm{~m}$ thick. The thickness of chromite-bearing horizons commonly ranges from 0.5 to $3 \mathrm{~m}$ thick, locally reaching $20 \mathrm{~m}$.

Kazakhstan is the world's second largest producer, after South Africa. Kazakhstan's biggest chromite producer, the Donskoy GOK (mining complex from the Aktyubinsk region) produced 2.6 million tonnes of chromite ore in 2000 (MBendi World: Mining, 2004). Russia does not produce significant amounts of chrome, only 130,000 tonnes each year.

In Northern Central Asia, chromium, nickel, and platinum group metal deposits occur in layered mafic (magnesium- and iron-rich) and ultramafic rock complexes that formed in volcanic arc or back-arc basins or in oceanic crust and mantle (ophiolite) that are now preserved along major fault (suture) zones that are areas of collision of major tectonic fragments (terranes). In the Altay Mountains, the Urals Mountains, and the Caucasus Mountains in Northern Central Asia (fig. 3), 
many of the chromium, nickel, and platinum-group metal deposits occur along suture zones. These deposits are generally complexly deformed, irregular, and discontinuous. The best example of this type of deposit in the region is the Almaz-Zhemchuzhina deposit in the southern Urals Mountains of Kazakhstan (147 million tonnes of chromium oxide) (Seltmann and others, 2003).

\section{Cobalt}

Cobalt is a bluish-gray, shiny, brittle metal that is used for catalysts, cemented carbides for cutting tools and drill bits; drying agents for paints; corrosion- and wear-resistant alloys; electroplating; magnets; and superalloys for jet engine components. Cobalt is not usually mined alone, and tends to be produced as a by-product of nickel and copper mining. The main ores of cobalt are cobaltite, glaucodot, and skutterudite. The world's major producers of cobalt are Congo, China, Zambia, and Australia. Compared to Zambia, the major 2003 and 2004 producer of cobalt, Russia, the major producer for the study area, produced about 10.7 percent of world production in 2003 (table 8) (U.S. Geological Survey, 2004, 2005). The world reserve base of cobalt is estimated to be about 13,000,000 tonnes.

Table 8. Cobalt - data for 2003 for world mine production, reserves, and reserve base for the study area and for the leading global producer (U.S. Geological Survey, 2004).

\begin{tabular}{l|l|l|l|l}
\hline Country & $\begin{array}{l}\text { Percent of world production, } \\
2003\end{array}$ & $\begin{array}{l}\text { Rank of world } \\
\text { production }\end{array}$ & $\begin{array}{l}\text { Percent of world } \\
\text { reserves }\end{array}$ & $\begin{array}{l}\text { Percent of world reserve } \\
\text { base }\end{array}$ \\
\hline Russia & 10.7 & 4 & 3.6 & 2.9 \\
Zambia & 25.6 & 1 & 3.9 & 5.7
\end{tabular}

About 16 major deposits containing cobalt, many as a secondary commodity, occur in the study area (table 2A). For most deposits, both cobalt and nickel are present. The deposits are mined principally for their nickel content and cobalt is recovered as a byproduct in the mining of nickel. In Greenland, Europe, Russia, and Northern Central Asia, the major cobalt deposit, where cobalt is a major secondary commodity, is the Norilsk-Talnakh district in Russia (fig. 11; table 2A). This mine is described in the below section on platinum. Most cobalt and nickel occur primarily in nickelsulfide igneous rock that may locally be weathered to form laterite surficial deposits. For more information on the characteristics of nickel-cobalt deposits, refer to the below section on nickel.

\section{Copper}

Copper is a reddish metal with a high electrical and thermal conductivity. Copper may be the first metal in use because copper artifacts dating to 8,700 $\mathrm{BC}$ have been found. Besides occurring in ore minerals, such as chalcopyrite, bornite, covellite, and chalcocite (combinations of copper with iron and sulfur), native copper metal also occurs. Because of copper's high ductility, malleability, thermal and electrical conductivity, and resistance to corrosion, it has become a major industrial metal; it ranks third after iron and aluminum in terms of quantities consumed. About onehalf of the copper produced is used in building construction (mainly copper wiring for construction and plumbing), and about one-fourth in electrical and electronic products. Lesser uses are for cookware, sterling silver, musical instruments, and water purification. Chile was the major 2003 and 2004 producer of copper, and Kazakhstan, Poland, and Russia, as the major producers for the study area, produced about 12.2 percent of world production (table 9) (U.S. Geological Survey, 2004, 2005). The world reserve base of copper is estimated to be about 940,000 million tonnes. In 2003, significant production occurred major mines in Australia, Canada, Chile, China, Indonesia, 
Kazakhstan, Mexico, Peru, Poland, Russia, and Zambia (U.S. Geological Survey, 2004). World production in 2003 was about 13.9 million tonnes copper (U.S. Geological Survey, 2004, 2005).

Table 9. Copper - data for 2003 for world mine production, reserves, reserve base, and resource base for the study area and for the leading global producer (U.S. Geological Survey, 2004; Singer, 1995).

\begin{tabular}{l|l|l|l|l}
\hline Country & $\begin{array}{l}\text { Percent of world production, } \\
2003\end{array}$ & $\begin{array}{l}\text { Rank of world } \\
\text { production }\end{array}$ & $\begin{array}{l}\text { Percent of world } \\
\text { reserves }\end{array}$ & $\begin{array}{l}\text { Percent of world reserve } \\
\text { base }\end{array}$ \\
\hline Kazakhstan & 3.5 & 10 & 3.0 & 2.1 \\
Poland & 3.6 & 9 & 6.3 & 5.1 \\
Russia & 5.1 & 6 & 4.2 & 3.2 \\
Chile & 35.1 & 1 & 31.6 & 38.4
\end{tabular}

About 190 major copper deposits occur in the study area (table 2A, fig. 7A). Some of the major copper deposits, where copper is the principal commodity, are as follows: Kadzharan in Armenia; Madneuli in Georgia; Ladderbjerg and Rubjerg Knude in Greenland; Aktogaj, Bozshakol, Dzhezqasghan, Mizek, and Qonyrat in Kazakhstan; Andash and Nurkazagan in Kyrgyzstan; Lubin in Poland; Degtyarskoye, Gai, Norilsk-Talnakh district, Peschanka, Podolska, Sakmara, Sibay, Uchalinskoe, Udokan, and Uzelga in Russia; Aqarkhar in Tajikistan; and Aq-Tash and Kalmakyr in Uzbekistan. The famous and large Norilsk-Talnakh district in Russia (fig. 11) is described in the below section on platinum.

\section{Major Copper Deposit Types}

Most of the copper production is derived from large, relatively low-grade ore deposits called porphyry copper deposits. They are interpreted to form beneath large continental-margin arc and island arc volcanoes (figs. 5, 12, 13) where copper becomes concentrated in hot, salty fluids (hydrothermal fluids) within the molten igneous rock of the volcano. The copper either is deposited in the cooling and solidifying molten rock and (or) is expelled with the hydrothermal fluids and deposited in adjacent rocks as the fluids cool and release their metal load. An average porphyry copper ore body contains 140 million metric tonnes of ore containing 0.5 percent copper and may contain additional gold, silver, and molybdenum (Singer and others, 2002). Most porphyry copper deposits have been found in rocks younger than 300 million years. Examples of major porphyry copper deposits in the study area are the Aksug, Kiyalykh-uzen, Lekyntelbei, Osennee, Peschanka, and Salavat deposits in Russia (table 2A).

Copper also occurs in nickel sulfide deposits as at the Norilsk-Talnakh district in northern Siberia (fig. 11), Russia that is described in the below section on platinum. In 2003, the mine produced about 451 thousand tonnes copper (Mining and Metals Company, Norilsk Nickel Annual Report, 2003). Other kinds of copper deposits also form where hot, salty fluids derived from sea water circulate through fractures in the rocks beneath the sea floor and dissolve metals. The metals subsequently are precipitated when the fluids rise to the bottom of the sea and are cooled and diluted thereby depositing their contained minerals (refer fig. 10 and to discussion under lead and zinc section).

Copper also occurs in major tropical sedimentary basins where hot brines dissolve copper in adjacent igneous rock with subsequent precipitation of copper. A classic example of this type of stratabound sediment-hosted copper deposit is the classic Kuperschiefer district of Germany (fig. 14) where copper sulfide minerals are interlayered with shale, mudstone, redbeds, and evaporates. Another classic type of a copper deposit is an ophiolite-hosted deposit hosted in oceanic crust and mantle (ophiolite) that is generated along oceanic spreading centers (fig. 5). This type of 
deposit is named Cyprus-type. A classic example in early Proterozoic rocks is the Keretti (Outokumpu) deposit in Finland (fig. 15).

Major Copper Deposits in Europe and Northern Central Asia

In eastern Greenland, two low grade sediment-hosted copper deposits occur at Ladderbjerg and Rubjerg Knude (Cox and others, 2003) in sedimentary basins that formed after an early Paleozoic mountain-building event (the Caledonia orogeny) and before the opening of the North Atlantic Ocean. They occur in the late Paleozoic Huledal Formation that occurs in small, faultbounded basins or grabens in this area. (Stemmerik and others, 1997).

In Europe, Poland is the major copper producer (table 9). The copper is mined from sedimentary deposits in the basin-hosted Kuperschiefer-type copper deposits at Lubin. Portugal and Sweden are the next two largest producers of copper that formed during hydrothermal alteration associated with igneous rocks.

Portugal and Spain have several polymetallic deposits located in the Iberian Pyrite Belt that is $60 \mathrm{~km}$ wide by $250 \mathrm{~km}$ long and extends from the southwestern coast of Portugal near Setubal to the Guadalquivir River near Seville, Spain (MBendi World: Mining, 2004). Major deposits in the belt are the Aguas Teñidas mine and the Lomero-Poyatos polymetallic deposit. Another major deposit is the Las Cruces deposit in Seville that contains an estimated 16 million tonnes of ore grading 6 percent copper.

In Russia, major copper deposits are related to both sedimentary and igneous rocks. The major deposits are the Degtyarskoye volcanogenic massive sulfide deposits, the Gai volcanogenic massive sulfide deposit, the Norilsk-Talnakh stratiform nickel-copper-PGE (platinum group elements) mine, the Podolska volcanogenic massive sulfide deposit, the Sibay volcanogenic massive sulfide deposit; and the Udokan sediment-hosted copper deposit. The famous and large Norilsk-Talnakh district in Russia is described in the below section on platinum.

In Northern Central Asia, copper deposits related to granite intrusions in the region can be divided into two ages (table 2A), Paleozoic deposits associated with the evolution of the Altay Mountains, and Mesozoic and Cenozoic deposits associated with evolution of the Tethys deformational belt. Paleozoic deposits occur in the magmatic (igneous) arcs of the Altay Mountains, both in the Kazakh Uplands and in the Tien Shan Mountains (fig .3). These deposits, which include some of the largest copper-gold deposits in the world, occur as disseminations and in stockwork bodies that are in, or and adjacent to granitic intrusions. These deposits often contain significant amount of by-product gold and molybdenum and are generally mined by open-pit methods. The most significant Paleozoic deposits of this type in the region are the Kalmakyr deposit, Uzbekistan (27 million tonnes copper, 2,798 tonnes gold) (fig. 16), Kounrad deposit, Kazakhstan (5 million tonnes copper), Nurkazagan deposit, Kazakhstan (1.5 million tonnes copper, 65 tonnes gold), and the Bozshakol, Kazakhstan (1.3 million tonnes copper, 49 tonnes gold) (White and others, 2001). The Mesozoic and Cenozoic copper deposits associated with granitic intrusions in the Lesser Caucasus Mountains (fig. 3) of Armenia and Azerbaijan and are generally smaller than the world-class Paleozoic deposits of the Altay Mountains (table 2A). The Kadzharan copper deposit, Armenia (1.2 million tonnes copper) (Singer and others, 2002) is a Cenozoic deposit that is related to a granitic intrusion that formed in a magmatic arc of the Tethys deformational belt. A more thorough description and world database of copper deposits related to granitic intrusion (porphyry copper deposits) is found in Singer and other (2002).

In Northern Central Asia, copper deposits related to sedimentary rocks occur in Paleozoic basins of the Altay Mountains. These deposits occur as tabular ore bodies of disseminated copper minerals within sandstone and carbonate rocks, with dimensions often only meters thick but 
kilometers to tens of kilometers in length and width. The best example of this deposit type in the region is the world-class sediment-hosted Dzhezkazgan deposit, Kazakhstan that contains an estimated 12 million tonnes of copper (fig. 17, table 2A)

\section{Gold}

Gold is a soft, yellow, corrosion-resistant precious metal that is beautiful, durable, and easily worked. It has been used throughout human history for jewelry and as currency. It is chemically stable, does not corrode or rust, and efficiently conducts heat and electricity. Gold is easily hammered into thin foils and drawn into long, thin wires. Gold is used primarily in coins and jewelry and is stored by many countries to support their currencies. Gold also is used in dentistry and in electrical and electronic applications. Compared to South Africa, the major 2003 and 2004 producer of gold, Russia the major producer in the study area, produced about 6.9 percent of world production (table 10) (U.S. Geological Survey, 2004, 2005). Many countries in Europe produce gold. However, the entire total gold production of these countries is about 1 percent of the world output. In 2003, production occurred from major mines in Spain, Finland, Sweden, Romania, Bulgaria, and France. About 190,000 tonnes of gold have been discovered in deposits around the world throughout history (Singer, 1995). The world reserve base of gold resources is estimated to be about 90,000 tonnes gold (U.S. Geological Survey, 2005).

Table 10. Gold - data for 2003 for world mine production, reserves, and reserve base for the study area and for the leading global producer (U.S. Geological Survey, 2004).

\begin{tabular}{l|l|l|l|l}
\hline Country & $\begin{array}{l}\text { Percent of world production, } \\
2003\end{array}$ & $\begin{array}{l}\text { Rank of world } \\
\text { production }\end{array}$ & $\begin{array}{l}\text { Percent of world } \\
\text { reserves }\end{array}$ & $\begin{array}{l}\text { Percent of world reserve } \\
\text { base }\end{array}$ \\
\hline Russia & 6.9 & 5 & 7.0 & 4.0 \\
South & 17.2 & 1 & 18.6 & 40.0 \\
Africa & & & &
\end{tabular}

\section{Major Gold Deposit Types}

One of the most common gold deposits types is a vein or hydrothermal deposit that occurs in groups of rocks called greenstone belts. During the $19^{\text {th }}$ century, geologists discovered these areas of deformed and metamorphosed volcanic and sedimentary rocks surrounded by granites in parts of the Archean age shields in North America, Southern Africa, India, and Australia (DeWit and Ashwahl, 1997). The predominance of green-colored metamorphosed volcanic rocks led to these areas being called greenstone belts. Greenstone belts are linear to irregular in shape and consist of groups of volcanic rock-rich metamorphosed rocks that average 20 to $100 \mathrm{~km}$ in width and extend for distances of several hundred kilometers (Windley, 1977). Most greenstone belts formed in a variety of geologic and tectonic settings early in Earth's history at the time when continental crust was developing.

Commonly, more than one tectonic setting is represented in a single greenstone belt. Some belts appear to have formed by plate tectonic processes at continental margins whereas others have not. Within a greenstone belt, hydrothermal gold-quartz vein deposits spatially are clustered near large fault zones in the study area (figs. 18, 19) (Robert, 1996; Roberts, 1988; Yeats and Vanderhor, 1998). Well known examples of this type of hydrothermal gold-quartz vein deposits are the Murantau mine in Uzbekistan (fig. 17, table 2A) and the Sukhoy Log deposit in southern Siberia (fig. 18). These fault zones are up to several kilometers wide, can be over $100 \mathrm{~km}$ long, and are nearly vertical. The vein deposits occur in faults, fractures, and folds that developed near the 
large fault zones and formed late in the sequence of events that compressed and metamorphosed the greenstone belts. Gold in some veins can be traced over two kilometers at depth. The fault zones were the pathways for flow of the hydrothermal fluids that formed the vein deposits. The gold vein deposits potentially can occur in any deformed and metamorphosed volcanic, plutonic, or clastic sedimentary rock. However, gold is more commonly concentrated if the rocks next to the veins are iron-rich and difficult to deform, such as banded iron formation, as described in the below section on iron.

Gold (and silver) deposits also are commonly associated with igneous and hydrothermal (epithermal) processes related to volcanic rocks that occur in major, mainly Mesozoic and Cenozoic continental-margin and island arcs (figs. 5, 12, 13). Examples in the study area are the Aginskoe, Ametistovoe, Asachinskoe, Dukat, Julietta, Kubaka, and Rodnikovoe deposits in Russia, and the Beregovo deposit in Ukraine (table 2). Significant quantities of gold are recovered from mining porphyry copper deposits (see copper discussion) and certain other types of sulfide deposits (see lead and zinc discussion).

Gold is also deposited from hydrothermal fluids permeate and alter host rock to produce dispersed, low-grade deposits of extremely fine-grained gold. These deposits, called Carlin-type deposits after the Carlin mine in Nevada, generally are mined by bulk-mining techniques in large open-pit mines (Thompson, 2002; Bettles, 2002). Some very rich gold deposits form in the roots of ancient hot-spring systems, usually as veins in volcanic rocks.

Gold also occurs in modern and ancient stream beds and beaches in surficial or placer deposits. Prospectors were quick to recognize that gold's high density and resistance to breaking were properties that caused gold nuggets to be concentrated by running water in placer deposits (fig. 20). The prospectors panned stream gravels in search of the gold in placer deposits, and then followed the gold upstream in search of the veins that were the source of the gold. Eventually, miners realized that if they could sift through larger amounts of rock, they could recover more gold. Thus, water cannons were used to break up placer deposits, and dredges were used to sift through many tonnes of the resulting sediment in a day.

\section{Major Gold Deposits in Europe and Northern Central Asia}

About 156 major gold deposits occur in the study area (table 2A, fig. 7B). Some of the major gold deposits, where gold is the principal commodity, are as follows: Nalunaq in Greenland; Aqtogai, Bakirchik, Kyrgyzstan and Vasilkovskoye, in Kazakhstan; Andash, Kumtor in Kyrgyzstan; Krasnogorskoe, Kyzyk-Chadr, and Omolon in Russia; Dalnee in Tajikistan; and the Amantaytav, Daugiztau, Kalmakyr, Muruntau, and Zarmitan in Uzbekistan (table 2A, fig. 7B).

In Greenland, the Nalunaq gold deposit is hosted in metamorphosed shale and metamorphosed basalt that are the same age as the Ketillidian deformational belt (1850-1800 million years age) (Stendal and Secher, 2002; Schjøth and others, 2000). The gold mineralization is localized in a shear zone and consists of a system of quartz veins. The Main Vein of Nalunaq is estimated to be $1,700 \mathrm{~m}$ long and 0.1 to $2 \mathrm{~m}$ wide. The gold is genetically related to hydrothermal fluids that were associated with the emplacement of late intrusive stages of the Julianehåb granite mass (batholith) (1,800 to 1,770 million years age).

Only a moderate number of gold deposits occur in Europe. These are the Asarel and Chelopech deposits in Bulgaria, the Juomasuo, Kutemajarvi, Pampalo, Portimo, Suurikiisikko, and Vihanti deposits in Finland, the Salsigne deposit in France, the Rammelsberg deposit in Germany, the Olympias/Kassandra, and Skouries/Fioska deposits in Greece, the Monteponi, Osilo, and Skouries/Fioska deposits in Italy, the Bucim deposit in Macedonia, the Flatt and Kongsberg deposits in Norway, the Borzecin/Sulmierzyce deposit in Poland, the Apuseni and Baia Mare 
districts in Romania, the Bor-Majdanpek deposit in Serbia and Montenegro, the Hodrusa district in Slovakia, the El Valle-Boinas-Carles and Rio Tinto deposits in Spain, and the Aitik, Boliden, Bjorkdal, Falun, Garpenberg, and Storliden deposits in Sweden (table 2A).

Substantial bedrock and placer gold mining has occurred in Russia according to a few published English-language sources (Nokleberg and others, 1997; Natapov and others, 2000; Ariunbileg and others, 2003). In eastern Russia, the following deposits have produced and (or) contain substantial gold reserves: the Natalka hydrothermal gold deposit contains an estimated 450 tonnes of gold. The gold occurs in zones of subparallel quartz veinlets that converge locally along strike into podiform and platy veins. The Nezhdaninka hydrothermal gold mine contains reserves of about 475 tonnes gold. The Ametistovoe hydrothermal gold mine contains reserves of about 96 tonnes gold. The Verkhne-Indigirsky placer district in eastern Russian produced 169 tonnes gold. The Verkhne-Yansky placer district in eastern Russian produced 137 tonnes gold. The Verkhneamursk placer district in eastern Russian produced 169 tonnes gold. The Verkhneselemdzha 1 placer district produced 137 tonnes gold. The Zeiya-Selemdzha placer district produced 137 tonnes gold. The Dambukiplacer district produced 185 tonnes gold. In western Russia, according to scare published sources, the following hydrothermal deposits contain or have produced and (or) contain substantial gold reserves: Berezovsk gold mine with production of 350 tonnes gold (Herrington, 2004); Sinyukhinskoye deposit with reserves of 20 tonnes gold (Ariunbileg and others, 2003); and Zarechenskoye deposit with reserves of 432 tonnes gold (Ariunbileg and others, 2003). The huge Norilsk-Talnakh district in Russia (fig. 11), that is a major world producer of platinum-group elements (PGE), copper, and nickel, also produced 968,000 ounces of gold in 2003 (Mining and Metals Company, Norilsk Nickel Annual Report, 2003) and is described in the below section on platinum.

In Northern Central Asia, the origin of many of the large gold deposits of the region remains controversial among the researchers who have and continue to study them. Some researchers call upon a granitic-intrusion-related origin whereas others believe they are related to broad orogenic (mountain building) and perhaps metamorphic processes. Nevertheless, it is clear that these types of gold deposits occur adjacent to major fault zones (sutures) that formed during collision of igneous arcs with each other or with continents. These main gold deposit types are gold quartz veins and stockwork (closely-spaced) vein zones that are mined by both open-pit and underground methods. The Muruntau deposit, Uzbekistan (one-time reported reserves of 5,246 tonnes of gold) is a deposit of this type, and the second largest gold deposit in the world. Other significant deposits (and reserves) of this type in the region include Daugiztau (261 tonnes of gold) and Zarmitan (340 tonnes of gold) in Uzbekistan, Kumtor (570 tonnes of gold) in Kyrgyzstan, and Vasilkovskoye (448 tonnes of gold) and Bakirchik (256 tonnes of gold) in Kazakhstan.

Indium

Indium is a malleable, silver-white metallic element that occurs mainly in the mineral sphalerite (zinc, iron, and sulfur) in lead and zinc deposits in hydrothermal-type mineral deposits. It is used principally for electroluminescent lamps and liquid-crystal displays, solder, plating over silver in mirrors, in aircraft bearings, and in compounds for making transistors. Compared to the China, the major 2003 and 2004 producer of indium, the major mining producer of indium is Russia that produced 5.1 percent of world production in 2003 (table 11). Other countires, in the region, such as Belgium and France, are refiners of indium. In 2003 and 2004, production occurred from major mines Canada, China, Peru, and Russia (U.S. Geological Survey, 2004, 2005). 
Table 11. Indium - data for 2003 for world mine production, reserves, and reserve base for the study area and for the leading global producer (U.S. Geological Survey, 2004).

\begin{tabular}{l|l|l|l|l}
\hline Country & $\begin{array}{l}\text { Percent of world production, } \\
2003\end{array}$ & $\begin{array}{l}\text { Rank of world } \\
\text { production }\end{array}$ & $\begin{array}{l}\text { Percent of world } \\
\text { reserves }\end{array}$ & $\begin{array}{l}\text { Percent of world reserve } \\
\text { base }\end{array}$ \\
\hline Russia & 5.1 & 5 & 8.0 & 5.0 \\
China & 33.4 & 1 & 11.2 & 21.7
\end{tabular}

* - Indium produced from processing of imported ore.

In Greenland, Europe, Russia, and Northern Central Asia, the three major indium deposits are the Degtyarskoye, Pyrkakai, and Uchalinskoe deposits in Russia (table 2A). All three deposits are volcanogenic massive sulfide deposits that formed in the rear or backs of island or continentalmargin igneous arcs (figs. 5, 10).

\section{Iron ore}

Iron is a silver-white lustrous, malleable, ductile, magnetic metal that occurs mainly in the minerals hematite, limonite, and magnetite (all containing iron and oxygen). Iron is one of the most abundant elements on Earth, but it does not occur in nature in its useful pure-metallic form. Iron ore is the term applied to a natural iron-bearing mineral or rock in which the content of iron is sufficiently high to be commercially extractable. Iron ore is the source of primary iron for the world's iron and steel industries. Compared to the China, the major 2003 and 2004 producer of iron, the countries Kazakhstan, Russia, Sweden, and Ukraine, the major producers in the study area, produced about 17.3 percent of world production in 2003 (table 12). Eight other countries in the study area produce iron ore, but only for local consumption. In 2003 and 2004, production occurred from major mines in Australia, Brazil, Canada, China, India, Iran, Kazakhstan, Mauritania, Russia, South Africa, Sweden, Ukraine, Venezuela, and the United States. The world reserve base of iron ore is 150 billion tonnes, and world resources are estimated to exceed 800 billion tonnes of crude ore containing more than 230 billion tonnes of iron (U.S. Geological Survey, 2004, 2005).

Table 12. Iron ore - data for 2003 for world mine production, reserves, and reserve base for the study area and for the leading global producer (U.S. Geological Survey, 2004).

\begin{tabular}{l|l|l|l|l}
\hline Country & $\begin{array}{l}\text { Percent of world } \\
\text { production, 2003 }\end{array}$ & $\begin{array}{l}\text { Rank of world } \\
\text { production }\end{array}$ & $\begin{array}{l}\text { Percent of world reserves } \\
\text { (crude ore) }\end{array}$ & $\begin{array}{l}\text { Percent of world reserve base } \\
\text { (crude ore) }\end{array}$ \\
\hline Kazakhstan & 1.6 & 12 & 5.3 & 5.8 \\
Russia & 8.2 & 4 & 17.0 & 17.1 \\
Sweden & 1.9 & 11 & 2.4 & 2.4 \\
Ukraine & 5.6 & 6 & 20.4 & 20.8 \\
China & 21.5 & 1 & 14.3 & 14.1
\end{tabular}

The most abundant type of iron-rich sedimentary rocks, called banded iron formation, contains more than 95 percent of the world's iron resources (Gross, 1996a). Banded iron formation is characterized by alternating iron-rich and quartz-rich layers and has greater than 15 percent metallic iron by weight. The thickness of individual layers varies from less than a millimeter to meters; overall, these layered rocks may be 100's of meters thick. The principal iron minerals are hematite and magnetite (Dardenne and Schobbenhaus, 2000). Banded iron formation has been found on all continents except Antarctica. Although iron deposits are widespread geographically, the largest ones formed almost exclusively during Precambrian time (Gross, 1996a). The extensive deposits of banded iron formations are associated with marine sedimentary units and formed during 
the Late Archean to Early Proterozoic (2.7 to 1.8 billion years ago). A notable example of an ironstone or banded iron formation deposit is at Pobeda in the Russian Northeast (fig. 21).

The iron resources are large because the deposits are laterally extensive. The iron minerals were precipitated from ocean water and were deposited uniformly over large areas. At the time they were formed, the deposits of iron formation associated with sedimentary rocks may have covered over $100,000 \mathrm{~km}^{2}$ (Trendall, 2002). Individual layers can be traced for over $100 \mathrm{~km}$ (Trendall, 2002). The deposits may have formed on submerged continental shelves surrounding Archean continents. Iron deposits also are studied because they provide insight into the early evolution of the Earth's atmosphere and oceans (Konhauser and others, 2002). They also provide insight on biological processes early in the Earth's history because of their close association with early biological organisms.

Iron ore is also mined from iron skarn (contact metasomatic or hydrothermal) deposits associated with granitic igneous plutons and from zoned, iron- and magnesium-rich igneous plutons. Both of these deposit types form mainly in the roots of island or continental-margin igneous arcs. A prominent example is the Kiruna iron granite mine in Sweden at about 1,600 million years ago, following intense volcanism, iron was precipitated from hydrothermal fluids on to a subjacent granite. The ore is a very pure magnetite-apatite mix, containing more than 60 percent iron and an average of 0.9 percent phosphorus. The mine is currently producing about 21 tonnes ore per year (www.ferret.com.au).

About 95 major iron ore deposits occur in the study area (table 2A, fig. 7D). Some of the major deposits are as follows: Isua banded iron formation deposit in Greenland with 2 billion metric tonnes grading 32 percent iron (Kirkham and Rafer, 2003); Kiruna iron-bearing granite deposit in Sweden (Lode, 2003); Bakcharskoye banded iron formation deposit in Russia with reserves of 28 billion tonnes ore grading 37.4 percent iron (Ariunbileg and others, 2003); Beloretskoye banded iron formation deposit in Russia with reserves of 250 million tonnes ore grading 33.5 percent iron (Ariunbileg and others, 2003); Enashiminskoye 2 iron skarn (hydrothermal) deposit in Russia with reserves of 450 million tonnes ore grading 36 to 51 percent iron (Ariunbileg and others, 2003); Gulinskoye 1 igneous deposit in Russia with reserves of 1.8 billion tonnes ore grading 22.4 percent iron (Ariunbileg and others, 2003); Kharlovskoye igneous deposit in Russia with reserves of 1.7 billion tonnes ore grading 15.3 percent iron (Ariunbileg and others, 2003); Magnitogorsk iron skarn (hydrothermal) deposit in Russia with production of 275 million tonnes iron (Herrington, 2004); and the Olenegorskoyeiron banded iron formation deposit in Russia with reserves of 128 million tonnes ore grading 32.3 percent iron (Kirkham and Rafer, 2003); and the Belozerka, Ingulets Kremenchug, Krivoy, and Rog deposits in Ukraine.

\section{Lead and Zinc}

Lead and zinc minerals commonly occur together and are described together in this section. Lead is a blue-gray, dense, ductile, malleable, very corrosion-resistant metal. More than threefourths of the lead produced is used by the transportation industry, mainly for lead-acid batteries. Remaining uses include ammunition, electrical, electronic, and communication applications, and radiation shields. About 350 million tonnes of lead has been discovered (Singer, 1995). The principal ore mineral for lead is galena (lead and sulfur) and for zinc is sphalerite (zinc, iron, and sulfur). Compared to Australia, the major 2003 and 2004 producer of lead, Kazakhstan, and Sweden, the major producers for the study area, and produced about 3.9 percent of world production (table 13) (U.S. Geological Survey, 2004, 2005). The world reserve base of lead is estimated to be about 140,000 thousand tonnes. In 2003 and 2004, production occurred from major mines in Australia, Canada, Kazakhstan, Mexico, Morocco, Peru, South Africa, and Sweden (U.S. 
Geological Survey, 2004). World production in 2003 was about 2,840 thousand million tonnes (U.S. Geological Survey, 2004, 2005).

Table 13. Lead - data for 2003 for world mine production, reserves, and reserve base for the study area and for the leading global producer (U.S. Geological Survey, 2004).

\begin{tabular}{l|l|l|l|l}
\hline Country & $\begin{array}{l}\text { Percent of world production, } \\
2003\end{array}$ & $\begin{array}{l}\text { Rank of world } \\
\text { production }\end{array}$ & $\begin{array}{l}\text { Percent of world } \\
\text { reserves }\end{array}$ & $\begin{array}{l}\text { Percent of world reserve } \\
\text { base }\end{array}$ \\
\hline Kazakhstan & 2.1 & 7 & 7.5 & 5.0 \\
Sweden & 1.8 & 9 & 0.8 & 0.7 \\
Australia & 25.2 & 1 & 22.6 & 20.2
\end{tabular}

Zinc is a blue-gray, lustrous metal that is malleable with heating. Because of its anticorrosion properties, more than one-half of zinc metal is used for galvanizing followed by the production of zinc-based alloys, brass, and bronze, and in electrical fuses, meter cases, roofing, and gutters. About 710 million tonnes of zinc has been discovered (Singer, 1995). Compared to China, the major 2003 amd 2004 producer of zinc, Kazakhstan, the major producer for the study area, produced about 4.1 percent of world production (table 14) (U.S. Geological Survey, 2004, 2005). The world reserve base of zinc is estimated to be about 140,000 thousand million tonnes. In 2003 and 2004, production of zinc occurred from major mines in Australia, Canada, Kazakhstan, Mexico, Morocco, Peru, South Africa, Sweden, and the United States (U.S. Geological Survey, 2004, 2005). The largest zinc deposit in the world is the Red Dog deposit in northwestern Alaska. World production in 2003 and 2004 was about 460,000 thousand tonnes (U.S. Geological Survey, 2004, 2005). Identified zinc resources of the world are about 1.9 billion tonnes (U.S. Geological Survey, 2004, 2005).

Table 14. Zinc - data for 2003 for world mine production, reserves, and reserve base for the study area and for the leading global producer (U.S. Geological Survey, 2004).

\begin{tabular}{l|l|l|l|l}
\hline Country & $\begin{array}{l}\text { Percent of world production, } \\
2003\end{array}$ & $\begin{array}{l}\text { Rank of world } \\
\text { production }\end{array}$ & $\begin{array}{l}\text { Percent of world } \\
\text { reserves }\end{array}$ & $\begin{array}{l}\text { Percent of world reserve } \\
\text { base }\end{array}$ \\
\hline Kazakhstan & 4.1 & 7 & 13.6 & 7.6 \\
China & 20.1 & 1 & 15.0 & 20.0
\end{tabular}

About 49 major lead deposits occur in the study area where lead is the principal commodity, and about 33 zinc deposits occur in the study area where zinc is the principal commodity (table 2A, fig. 7C). Some of the major lead and zinc deposits, where one or both are the principal commodities, are as follows: Bleiberg in Austria; Gorubso-Kombinat in Bulgaria; Mullikkoräme and Vihanti in Finland; Saint-Salvy in France; Davidgaredzhinskoe in Bulgaria; Meggen and Rammelsberg, in Germany; the Lisheen and Silvermines silver mines in Ireland; Monteponi in Italy; Madneuli (also with copper deposit of the Bolnisi district in Georgia; Black Angel and Citronen Fjord, Peary Land in Greenland; Aqzhal, Beloubinskoe, Maleevskoe, Mirgalimsai, Nikolaevskoe, Priorskoe, Tekeli, Uzynjal, and Zhairem in Kazakhstan; Bytom District in Poland; Berezitovoe, Gai, Gorevskoye, Jubileinoye, Khotoidokh, Korbalihinskoye, Safyanovska, Salairskoye, Sibay, Srednee, Stepnoye, Talovskoye, Uchalinskoe, Uzelgamassive, and Zacharovskoye in Russia; Aguas Tenidas Este, Rubailes-Santa Barbara, Laisvall, Nygruvan and Zinkgruven in Sweden; Trepca in Serbia; Montenegro and Nikolaevskoe in Ukraine; and Lashkerek and Uchkulach in Uzbekistan.

Lead and zinc commonly occur in deposits that form from low-temperature hydrothermal fluids. The following four main types of hydrothermal lead and zinc deposits are explored for, and 
recognized on the basis of how hydrothermal fluids were generated and migrated, the distribution of ore minerals in the deposit, and the geologic setting.

\section{Volcanogenic Massive Sulfide Deposit Type of Lead and Zinc}

In the volcanogenic (volcanic-origin) massive sulfide deposit type, hydrothermal solutions mix with ocean water and deposit large quantities of iron, zinc, and lead minerals onto mounds and layers on the sea floor (figs. 5, 22). Volcanogenic massive sulfide deposits occur in Precambrian to recent rocks, but the greatest number, in terms of average size and contained metal, formed in early to middle Mesozoic (about 200 to 100 million years) volcanic arcs (Sherlock and Michaud, 2000). The average size tends to be small, in the range of a few tens of thousands to a few tens of millions of tonnes of ore. Modern volcanogenic massive sulfide deposits are forming today on the ocean floor at spreading centers or in the rear parts of island arcs (fig. 5). Volcanogenic massive sulfide deposits are associated with magmas generated at convergent plate boundaries, generally in marine (under water) settings. The oldest deposits, in Archean-age rocks, contain less lead than younger deposits. Deposits of all ages also may contain recoverable amounts of copper, gold, and silver.

\section{Sedimentary Exhalative Deposit Type of Lead and Zinc}

In the sedimentary exhalative deposit type (fig. 23), hydrothermal solutions are generated as water-rich sediments are deeply buried in basins within the Earth, later to be expelled when pressure is released during folding and faulting Sedimentary exhalative lead and zinc deposits are a type of hydrothermal deposit found in sedimentary basins (figs. 5, 23) (Lydon, 1988, 1996). These basins commonly form as continents are pulled apart by rifting. Sedimentary exhalative deposits typically occur in large basins filled with more than $10 \mathrm{~km}$ of sediments. Silver, and less commonly copper, may be present in economic amounts in sedimentary exhalative deposits. Globally, sedimentary exhalative deposits are generally younger than 1,800 million years.

\section{Mississippi Valley Deposit Type of Lead and Zinc}

In the Mississippi valley deposit type, lead and zinc deposits form from hydrothermal fluids related to sedimentary basins. However, in these deposits, the hydrothermal fluids move through aquifers (water-bearing rocks), mix with other fluids, and deposit minerals in open cavities in carbonate sedimentary rocks such as limestone. The movement of hydrothermal fluids in the sedimentary basins is driven by forces resulting from plate boundary interactions. These deposits form in the relatively undeformed sedimentary rocks that generally occur inland from the deformational belts formed at convergent plate margins (fig. 5).

\section{Polymetallic Replacement Deposit Type of Lead and Zinc}

In the polymetallic replacement deposit type, lead and zinc deposits occur in favorable carbonate (e.g. limestone) sedimentary rock commonly forms near intrusions of molten igneous rock where hydrothermal fluids emanating from the intrusion selectively replace the adjacent carbonate rocks with ore and other associated minerals (Nelson, 1996). This replacement process forms ore bodies having a variety of irregular shapes. Ore bodies deposited parallel to sedimentary layering in carbonate rocks often are called mantos, which is the Spanish word for blanket. Conversely, ore bodies that form in fractures, and other inhomogeneous parts of the sedimentary rock, that cut across the sedimentary layers, have a variety of names, including: veins, when they 
form sheet-like and tabular masses in fractures; and in pipes or chimneys, when they have the shape of nearly vertical cylinders. Polymetallic replacement deposits contain variable amounts of silver, lead, zinc, and other metals. Bismuth may be a significant byproduct of mining of lead.

Major Lead-Zinc Deposits in Greenland, Europe, Russia, and Northern Central Asia

In Greenland, two significant lead and zinc deposits occur. The Black Angel deposit occurs in the Rinkian mountain-building belt in western Greenland and occurs in an extensive marble sequence in multiply-metamorphosed Archean gneiss (Thomassen, 2003). The main ore minerals occur in metamorphosed limestone and dolomite. The ore bodies consist of flat-lying, massive lenses of sulfides (pyrite, sphalerite, and galena), and range up to 30 meters thick. Ten lenses were large enough to be mined. The deposit is either a Mississippi Valley-type or a sedimentaryexhalative type deposit. Zinc and lead ore was mined from this deposit from 1973 to 1990.

The Citronen Fjord deposit occurs at the eastern end of the Franklinian Basin (Van der Stijl and Mosher, 1998). It is a bedded, lead and zinc-bearing sedimentary-exhalative massive sulfide deposit. The sulfides are hosted in the dark chert, shale, siltstone, and mudstone that formed in deep water. Three main sulfide sheets occur in a 200-m-thick stratigraphic sequence. The sulfides consist of massive to bedded pyrite (iron and sulfur) with variable amounts of sphalerite (zinc, iron, and sulfur) and minor galena (lead and sulfur). The sulfides extend at least $3 \mathrm{~km}$ with a maximum width of $500 \mathrm{~m}$.

In Europe, lead and zinc commonly occur together in the same deposits but can vary greatly in proportion. Europe contributes about 10 percent of each commodity in terms of world production. Poland, Sweden, Spain and Ireland are the leading producers of lead and zinc with many other countries contributing lesser amounts.

In Ireland, the Tara mine is one of Europe's largest lead-zinc mines, and produces 152,000 tonnes zinc and 35,000 tonnes lead concentrates per year (MBendi World: Mining, 2004). The mine has proven and probable reserves of 12.1 million tonnes grading 9.2 percent zinc and 2.2 percent lead. The nearby Bula deposit has resources of about 8 million tonnes grading 10 percent zinc and 2 percent lead. The Galmoy Mine contains an estimated 10 million tonnes grading at 11.8 percent zinc and 1.3 percent lead.

In Sweden, most lead-zinc deposits are igneous (polymetallic) type with both massive and disseminated sulphide minerals, along with one sediment-hosted deposit (MBendi World: Mining, 2004). The major deposits are the Aitik copper mine, the Laisvall lead-zinc mine, Garpenberg with two zinc-copper-lead mines, and the Boliden district with six polymetallic mines. Together these produce zinc, copper, lead, gold and silver. Kristenberg is Sweden's deepest mine at 1,000 $\mathrm{m}$ and produces approximately 560,000 tonnes ore per year. The Renstrom mine, has been faced with declining ore reserves, but has identified additional reserves nearby at 1,000 $\mathrm{m}$ depth. The Petiknas mine is located adjacent to the Renstrom mine. The Kristineberg, Petiknäs, Renström and Maurliden mines together produced 1.2 million tonnes of ore.

The major deposits in Russia for which production or reserve data are available (Ariunbileg and others (2003) or Herrington (2004)) are as follows (table 2A, fig. 7C): Berezitovoe polymetallic vein deposit with 131,000 tonnes zinc, 80 thousand tonnes lead; Degtyarskoye volcanogenic massive sulfide deposit with production of 2,210,000 tonnes zinc; Gai volcanogenic massive sulfide deposit with production 2,814 000 tonnes zinc ore grading 0.6 percent zinc; Gorevskoye world class sedimentary exhalative deposit; Jubileinoye volcanogenic massive sulfide deposit with reserves of 100,800 tonnes lead and 389,900 tonnes zinc; Khotoidokh volcanogenic massive sulfide deposit with resources of 180,000 tonnes lead and 900,000 zinc; Korbalihinskoye volcanogenic massive sulfide deposit with reserves of 497,800 tonnes lead and 2,403,200 tonnes 
zinc; Podolska volcanogenic massive sulfide deposit with production of 848,000 tonnes ore grading 1.05 percent zinc; Safyanovska volcanogenic massive sulfide deposit with production of 313,000 tonnes ore grading 0.9 percent zinc; Salairskoye polymetallic deposit with reserves of 72,400 tonnes lead, 545,700 tonnes zinc; Sibay massive sulfide deposit with production of 1,840,000 tonnes ore grading 1.6 percent zinc; Srednee volcanogenic massive sulfide deposit with reserves of 218,700 tonnes lead and 423,100 tonnes zinc; Stepnoye volcanogenic massive sulfide deposit with reserves of 163,300 tonnes lead and 325,800 tonnes zinc; Talovskoye volcanogenic massive sulfide deposit reserves of 176,900 tonnes lead and 370,400 tonnes zinc; Uchalinskoe massive sulfide deposit with production of 4,236,900 tonnes ore grading 3.73 percent zinc; Uzelgamassive sulfide deposit with production of 1,961,760 tonnes ore grading 1.4 percent zinc; and the Zacharovskoye volcanogenic massive sulfide deposit reserves of 165,500 tonnes lead and 294,000 tonnes zinc. Many of these deposits contain or have produced moderate to substantial amounts of copper, gold, silver, and barium. The major lead and zinc deposits occur in the Urals Mountains that form the eastern margin of European Russia, Altay Mountains of southern Siberia, and the Chersky Mountains and adjacent area in northeastern Russia (figs. 3, 7C). The major deposit types are volcanogenic massive sulfide, sediment-hosted, and polymetallic vein lead and zinc deposit types (table 2A). Most of the volcanogenic massive sulfide and sediment-hosted sulfide deposits formed along the back arc areas of island or continental-margin igneous arcs from the Proterozoic (about 800 million years ago) to the Cretaceous (about 100 million years ago).

In Russia, the current, significant lead-zinc mining regions are Dalpolimetal in the Russian Far East, Nerchinsk in the Trans-Baikal region, and Salair and Altay deposits in western Siberia east of the Urals Mountains (fig. 3) (MBendi World: Mining, 2004). New developments are the Ozemoye deposit in the TransBaikal region, the Goryevskoye deposit in North Caucasus Mountains, and several deposits in the Altay Mountains (fig. 3).

In Northern Central Asia, copper, lead, and zinc volcanogenic massive sulfide deposits occur primarily in the back-arc basin environments and in the submarine environments of island arcs in the Altay Mountains in northeastern Kazakhstan, the Urals Mountains in northern Kazakhstan, and the Caucasus Mountains in Georgia and southwestern Russia. These deposits consist of tabular massive bodies of copper, zinc, and lead sulfides and can also contain commercial quantities of gold, silver, and barite. Examples of significant deposits of this type in the region include Maleevskoe in the Altay Mountains of northeastern Kazakhstan (3.1 million tonnes of zinc, 1 million tonnes of copper, 489,000 tonnes of lead), Priorskoe, in the southern Urals Mountains of Kazakhstan (1.4 million tonnes of zinc, 375,000 tonnes of copper, 3.85 tonnes of gold and 590 tonnes of silver), and the Madneuli deposit of the Bolnisi district in Georgia (517,000 tonnes of copper, 88,500 tonnes of zinc, 40 tonnes of gold, and 1 million tonnes of barite) (Seltmann and others, 2003).

In Northern Central Asia, major sediment-hosted lead and zinc deposits occur in Paleozoic back-arc basins of the Altay Mountains in northeastern Kazakhstan and southern Russia. The deposits consist of tabular to massive bodies to disseminations of copper, zinc, and lead sulfides in shale, sandstone and carbonate rock. The deposit dimensions typically are a few meters thick but may range up to many kilometers long and wide. The Zhairem deposit ( 0.4 million tonnes lead and 1 million tonnes of zinc), Tekeli deposit ( 0.4 million tonnes lead, 1 million tonnes zinc), and the deposits of Kazakhstan are the best examples. A more thorough description of lead and zinc deposits related to sedimentary rocks occurs in Goodfellows and other (1993) and Sangster (1996). 


\section{Manganese}

Manganese is a silver, very brittle, and hard metal that is essential for improving the properties of iron and steel. Manganese is also used in aluminum alloys, batteries, colorants, and fertilizers. Manganese is obtained mainly from the manganese oxide minerals such as pyrolusite, hausmanite, manganite, and rhodochrosite (manganese carbonate). Manganese is mined from seawater, brines, sea-floor nodules, or manganese-rich limestone, and igneous rock. Compared to South Africa, the major 2003 and 2004 producer of manganese, Ukraine, the major producer for the study area, produced about 10.4 percent of world production (table 15) (U.S. Geological Survey, 2004). The world reserve base of manganese is estimated to be about 5,100,000 thousand tonnes. In 2003 and 2004, production occurred from major mines in Australia, Brazil, China, Gabon, India, Kazakstan, Mexico, South Africa, Ukraine, and the United States (U.S. Geological Survey, 2004, 2005). World production in 2003 was about 11,000 thousand tonnes (U.S. Geological Survey, 2005).

Table 15. Manganese - data for 2003 for world mine production, reserves, and reserve base for the study area and for the leading global producer (U.S. Geological Survey, 2004).

\begin{tabular}{l|l|l|l|l}
\hline Country & $\begin{array}{l}\text { Percent of world production, } \\
2003\end{array}$ & $\begin{array}{l}\text { Rank of world } \\
\text { production }\end{array}$ & $\begin{array}{l}\text { Percent of world } \\
\text { reserves }\end{array}$ & $\begin{array}{l}\text { Percent of world reserve } \\
\text { base }\end{array}$ \\
\hline Ukraine & 10.4 & 3 (tied with Australia) & 84.3 & 11.7 \\
South & 20.4 & 1 & 19.3 & 90.2 \\
Africa & & & &
\end{tabular}

There are about 10 major manganese deposits occur in the study area where manganese is the principal commodity (table 2A, fig. 7E). The major deposits are as follows: Obrochishte and Varana District in Bulgaria; Chiatura and Rodinouli-Cholatunskoe in Georgia; Urkut District in Hungary; several deposits in Kazakhstan; and the Bol'shoi Tokmak, and Nikopol district in Ukraine. The major mineral deposit types are sedimentary and surficial (table 2A, fig. 5).

Kazakhstan has 11 manganese deposits in the central Zhezkazgan region with a resource of about 560 million tonnes ore grading at an average of 21 percent manganese (MBendi World: Mining, 2004). High-grade ore (40 percent manganese) occurs at the Kamys and Ushkatyn deposits that contain only 0.2 percent of the country's reserves. Other major mines occur at Atasuruda, Kazakhmarganets, and Sary-Arkapolimetal, Zhairem Dalnezapadny, Ushkatyn-III and, Zapadny.

Offshore (marine) areas may contain large submarine deposits of manganese and a number of other nonfuel mineral resources are known, but are not the focus of this report that about on-land mineral resources. An example of the largest or one of the largest of these marine resources is the enormous amount of metal estimated to occur in deposits of manganese nodules that form on the deep ocean floor. The possible magnitude of these resources is represented in the table 16 for manganese nodules in the North Pacific high-grade area: 
Table 16. Manganese resources in the ocean (U.S. Geological Survey, 2004).

\begin{tabular}{l|l|l}
\hline Metal & $\begin{array}{l}\text { Manganese nodules, North Pacific high-grade area, six million } \\
\mathrm{km}^{2} \text {, million metric tonnes metal (Mero, 1977) }\end{array}$ & $\begin{array}{l}\text { USGS on-land reserve base, million } \\
\text { metric tonnes metal (USGS, 2003) }\end{array}$ \\
\hline Manganese & 11,000 & 5,000 \\
Cobalt & 115 & 13 \\
Nickel & 650 & 140 \\
Copper & 520 & 950 \\
Zinc & 53 & 450 \\
Molybdenum & 23 & 0.019
\end{tabular}

Manganese nodules form in two separate regions of the oceans in different ways (fig. 5) (Gill, 2003, and French Research Institute for Exploitation of the Sea, 2000): (1) as hydrothermal deposits above basalt lavas that form mid-oceanic ridges along spreading centers; and (2) away from spreading centers in sea floor sediments where the nodules form by slow deposition of metals and other chemical elements directly from seawater, or by a variety of secondary processes that remobilize metals from seawater, marine sediments and volcanic rocks, and organic emanations or debris, and redeposit them in nodules at the sediment-seawater interface on the sea floor.

Although interest is greatest for the economic potential of nickel, copper, and cobalt in the nodules, their development is unlikely for several decades (Wiltshire, 2001) because of the high cost of mining, a variety of environmental effects, and global disputes about ownership arising from the occurrence of most nodule fields outside of national Exclusive Economic Zones (Gill, 2003).

\section{Mercury}

Even though mercury use has been discontinued in many household items such as thermometers and batteries in the U. S. because of health concerns, there are other uses for the metal that have not been replaced with substitutes. For instance, the largest user of mercury is as an electrolyte in the making of chlorine-caustic soda chemicals. It is also used in automobile convenience switches, barometers, computers, mercury-vapor and fluorescent lamps and thermostats. Mercury also is used in cleansers, pesticides, folk medicine, and in gold processing. Mercury is derived mainly from the mineral cinnabar (mercury and sulfur) and to a lesser degree from native mercury, which is the only metal that is liquid at ordinary temperatures.

Compared to Algeria and Spain, the major 2003 and 2004 producers of mercury, Kyrgyzstan, the other the major producer for the study area, produced 15.6 percent of world production in 2003 (table 17) (U.S. Geological Survey, 2004). The world reserve base of mercury is estimated to be about 240,000 tonnes, and the total mercury production in 2003 was 1,600 tonnes. In 2003 and 2004, production occurred from major mines in Algeria, Italy, Kyrgyzstan, Spain, and the United States (U.S. Geological Survey, 2004). Spain led the world in mercury production with over 30 percent in 2003 (U.S. Geological Survey, 2004, 2005) from the famous igneous-related Almanden deposit near the town of Almanden. Spain contains over half the known mercury reserves in the world in that deposit. 
Table 17. Mercury - data for 2003 for world mine production, reserves, and reserve base for the study area and for the leading global producer (U.S. Geological Survey, 2004).

\begin{tabular}{l|l|l|l|l}
\hline Country & $\begin{array}{l}\text { Percent of world production, } \\
2003\end{array}$ & $\begin{array}{l}\text { Rank of world } \\
\text { production }\end{array}$ & $\begin{array}{l}\text { Percent of world } \\
\text { reserves }\end{array}$ & $\begin{array}{l}\text { Percent of world reserve } \\
\text { base }\end{array}$ \\
\hline Italy & NA & NA & Unknown & 28.8 \\
Kyrgyzstan & 20.0 & 3 & 6.25 & 5.4 \\
Spain & 10.0 & 2 & 63.3 & 37.5 \\
Algeria & 20.0 & 1 & 2.0 & 1.0
\end{tabular}

Mercury deposits generally occur in three main settings (fig. 5): (1) in areas of modern or ancient, near-surface hot springs; (2) in layers in volcanic rocks along major, deep fault zones (Almanden type); and (3) along zones of hydrothermal alteration in fault-bounded sequences of mafic (magnesium- and iron-rich) and ultramafic igneous rock that are preserved in subduction zone complexes.

Ten major mercury deposits occur in the study area (table 2A, fig. 7B). The major mercury deposits are as follows: Chonkoy, Janguz-Bulak, Khaidarkan, and Qara-Archa deposits in Kyrgyzstan; Aktashskoye, Tamvatney, and Zapadno-Paljanskoe deposits in Russia; Idrija deposit in Slovenia; the giant Almanden deposit in Spain; and Dzhizhikrut deposit in Tajikistan. All deposits formed under hydrothermal conditions.

\section{Molybdenum}

Molybdenum is a metallic element used principally as an alloying agent in cast iron, steel, and superalloys to enhance hardness, strength, toughness, and wear and corrosion resistance. Molybdenum is derived from the mineral molybdenite (molybdenum and sulfur) that primarily occurs as disseminations in granite bodies in porphyry molybdenum deposits. Copper is often associated with, or is the primary economic mineral in such deposits. Compared to the United States, the major 2003 and 2004 producer of molybdenum, Armenia, Kazakhstan, Kyrgyzstan, Russia, and Uzbekistan, the major producers for the study area, produced about 6.2 percent of world production in 2003 (table 18) (U.S. Geological Survey, 2004). The world reserve base of molybdenum is estimated to be about 19,000,000 tonnes. In 2003, the total molybdenum production was estimated at 127,000 tonnes. In 2003 and 2004, production occurred from major mines in Armenia, Canada, Chile, China, Iran, Kazakhstan, Kyrgyzstan, Mexico, Mongolia, Peru, Russia, Uzbekistan, and the United States (U.S. Geological Survey, 2004, 2005).

Table 18. Molybdenum - data for 2003 for world mine production, reserves, and reserve base for the study area and for the leading global producer (U.S. Geological Survey, 2004).

\begin{tabular}{l|l|l|l|l}
\hline Country & $\begin{array}{l}\text { Percent of world production, } \\
\text { 2003 }\end{array}$ & $\begin{array}{l}\text { Rank of world } \\
\text { production }\end{array}$ & $\begin{array}{l}\text { Percent of world } \\
\text { reserves }\end{array}$ & $\begin{array}{l}\text { Percent of world reserve } \\
\text { base }\end{array}$ \\
\hline Armenia & 3.1 & 6 & 2.3 & 2.1 \\
Kazakhstan & 0.2 & 13 & 1.5 & 1.0 \\
Kyrgyzstan & 0.2 & 12 & 1.2 & 0.9 \\
Russia & 2.3 & 8 & 2.8 & 1.9 \\
Uzbekistan & 0.4 & 11 & 0.7 & 0.8 \\
United & 26.8 & 1 & 31.4 & 28.3
\end{tabular}


Generally, molybdenum is produced as a byproduct of mining copper, especially mining of porphyry copper deposits, which are discussed in the above section on copper (figs. 5, 12). The characteristics of porphyry molybdenum deposits are similar to those of porphyry copper deposits that also are discussed above.

Fifteen major molybdenum deposits occur in the study area (table 2A, fig. 7C). Major deposits are the Malmbjerg in Greenland; Dorozhilovskoe, Karatas, Koktenkol, Konyrat, and Smirnovskoe in Kazakhstan; Knaben in Norway; Bugdainskoe, Sorskoe, and Zhirekenskoe in Russia; and Dalnee in Tajikistan.

In Greenland, the Malmbjerg porphyry (hydrothermal) molybdenum deposit occurs in the Tertiary Werner Bjerge sodium- and potassium-rich granites in the eastern part of the region (Mining Journal, 2000; Nielsen, 1976). Magmatism that formed the granites is related to rifting associated with the opening of the North Atlantic Ocean. In Kazakhstan and Russia, the major molybdenum deposits also occur in sodium- and potassium-rich granites (porphyry molybdenum or porphyry copper-molybdenum deposits).

\section{Nickel}

Nickel is a silvery-white, hard, ductile metallic element that occurs in rocks that compose the Earth's mantle and are derived from the mantle. Most nickel is used to manufacture stainless steel, lesser amount is used in other steel and non-ferrous (including "super") alloys and batteries, often for highly specialized industrial, aerospace, chemical, and military applications. A minor amount is used in electroplating. The remaining uses are coins and a variety of nickel chemicals. In 2003 and 2004, Russia was the leading world producer of nickel. Together with Greece, other countries in the study area produced about 25.2 percent of world production in 2003 (table 19) (U.S. Geological Survey, 2004, 2005). In 2003 and 2004, production occurred from major mines in Australia, Botswana, Brazil, Canada, China, Columbia, Cuba, Dominican Republic, Greece, Indonesia, New Caledonia, Philippines, Russia, South Africa, Venezuela, Zimbabwe, and the United States (U.S. Geological Survey, 2004, 2005).

In 2003 and 2004, the total nickel production was estimated at 1,400,000 tonnes (U.S. Geological Survey, 2004, 2005). The world reserve base of nickel is estimated to be about 1,400,000 tonnes. In some regions, nickel deposits are locally associated with copper, platinumgroup element, and chrome deposits that form in mafic (magnesium- and iron-rich) plutonic (subsurface) igneous bodies.

Table 19. Nickel - data for 2003 for world mine production, reserves, and reserve base for the study area and for the leading global producer (U.S. Geological Survey, 2004).

\begin{tabular}{l|l|l|l|l}
\hline Country & $\begin{array}{l}\text { Percent of world production, } \\
2003\end{array}$ & $\begin{array}{l}\text { Rank of world } \\
\text { production }\end{array}$ & $\begin{array}{l}\text { Percent of world } \\
\text { reserves }\end{array}$ & $\begin{array}{l}\text { Percent of world reserve } \\
\text { base }\end{array}$ \\
\hline Greece & 1.6 & 13 & 0.8 & 0.6 \\
Russia & 23.6 & 1 & 10.7 & 6.5
\end{tabular}

Nickel and cobalt commonly occur together in deposits that are mined principally for their nickel content. Cobalt is recovered in the process of mining nickel. Most of the nickel and cobalt come from two general types of deposits: nickel laterite and igneous nickel-copper-PGE (platinum group elements) deposits. Nickel laterite (fig. 9) forms by the weathering of nickel-bearing rock in areas with a tropical climate and good drainage. During this process, silica is leached from the rocks, leaving a soil enriched in oxide minerals, nickel, cobalt, and iron. The principal nickel 
minerals are garnierite (hydrous nickel silicate) and nickeliferous limonite (hydrated nickel-bearing iron oxide).

Igneous nickel-sulfide deposits occur in igneous rocks rich in magnesium, nickel, copper, and PGE. As the igneous bodies (magma) cool and crystallize, a separate dense liquid rich in sulfur, iron, nickel, copper, and occasionally platinum-group elements forms within the magma. Once formed, the liquid will not remix with the silicate-rich magma (like the separation of oil and vinegar in a salad dressing). Eventually, the sulfur-iron-nickel-copper-rich liquids accumulate separately and solidify forming a variety of ore deposit minerals, that include pentlandite (iron nickel sulfide), which is mined for its high nickel content. Classic examples of nickel-copper-PGE sulfide mines hosted in mafic (magnesium- and iron-rich) igneous plutons or layered intrusions are at the Norilsk-Talnakh district in northern Siberia (fig. 11), Pechenga, and Monchegorsk district in Russia.

About twenty major nickel deposits occur in the study area (table 2A, fig. 7E). Some of the major deposits, where nickel is the principal commodity, are as follows: Guri Kuq in Albania; Enonkosk, Hitura, Kotalahti, Lahnaslampi, Outokumpu, Vammala, and Vuonos in Finland; Larymna in Greece; Bochetkol'skoe, Kempirsai, Kundybajskoe, and Oktjabr'skoe in Kazakhstan; Rzanovo in Macedonia; Flatt and Tellnes in Norway; Monchegorsk, Norilsk-Talnakh; and Pechenga in Russia. All these major deposits occur in iron- and magnesium-rich (mafic) igneous rocks.

In Greece, nickel is produced from a surficial deposit derived from the weathering of a magnesium- and iron-rich igneous rock called peridotite. Finland contains nickel deposits hosted in Archean mafic and ultramafic basalt flows named komatiite. Examples are at Vaara-Kauniinlampi, Peura-aho and Hietaharju.

In Russia, the Mining and Metals Company - Norilsk Nickel currently controls more than 20 percent of the global nickel market and the company produces 91 percent of Russia's nickel, 57 percent of its copper, 80 percent of its cobalt, and 95 percent of its PGE (platinum group elements) (MBendi World: Mining, 2004). Nickel ores are being mined in the Norilsk-Talnakh district in Siberia (85 percent) (Bond and Levine, 2001) and on the Kola Peninsula (15 percent) with minor nickel laterite ores being produced from the Urals Mountains. The major Russian nickel mines in eastern Siberia are at Komsomolsky, Norilsk-Talnakh district, Mayak, Medvezhii Ruchei, Oktyabrsky, Skalistoe, Taimyrsky, on the Kola Peninsula in northwest Russia there are several mines in the Zapolyarny district. These mines are also major producers of copper, PGE, and cobalt. The famous and large Norilsk-Talnakh district in Russia is described in the below section on platinum. In 2003 the district produced about 239,000 tonnes nickel (Mining and Metals Company, Norilsk Nickel Annual Report, 2003).

\section{Platinum-Group Elements}

The platinum-group elements (PGE) are iridium, osmium, palladium, platinum, rhodium, and ruthenium. In general, platinum-group elements exhibit high density, high electrical conductivity, high melting points, and low reactivity. Platinum, the best known PGE, is a silverwhite metallic element that is used in automobile pollution abatement systems (catalytic converters), dentistry, fabrication of laboratory equipment, and jewelry, and as a catalyst in the production of industrial chemicals and gasoline. Compared to the South Africa, the major 2003 and 2004 producer of platinum-group elements, Russia, the major producer for the study area, produced about 19.2 percent of world production in 2003 (table 20) (U.S. Geological Survey, 2004, 2005). In 2003 and 2004, production occurred from major mines in Canada, Russia, and South Africa (U.S. Geological Survey, 2004, 2005). In some regions, PGE deposits are locally associated with copper, 
nickel, and chrome deposits that form in mafic- and iron-rich (mafic) plutonic (subsurface) igneous bodies.

Table 20. Platinum-group elements - data for 2003 for world mine production, reserves, and reserve base for the study area and for the leading global producer (U.S. Geological Survey, 2004).

\begin{tabular}{l|l|l|l|l|l}
\hline Country & $\begin{array}{l}\text { Platinum: Percent of } \\
\text { world production, 2003 }\end{array}$ & $\begin{array}{l}\text { Palladium: Percent of } \\
\text { world production, 2003 }\end{array}$ & $\begin{array}{l}\text { Rank of world } \\
\text { production }\end{array}$ & $\begin{array}{l}\text { PGE: Percent of } \\
\text { world reserves }\end{array}$ & $\begin{array}{l}\text { PGE: Percent of } \\
\text { world reserve base }\end{array}$ \\
\hline Russia & 19.2 & 43.2 & 1 & 8.7 & 8.3 \\
South & 72.2 & 37.8 & 2 & 88.5 & 88.7 \\
Africa & & & & &
\end{tabular}

Most PGE deposits occur in large layered igneous bodies called stratiform complexes or in large dikes and sills. These complexes are mainly Archean age (2.5 billion years old and older) and consist of layers of magnesium- and iron-rich (mafic) minerals (olivine and pyroxene), and (or) calcium, sodium, and potassium silicate minerals called feldspar. The layers range up to a few meters thick and are interpreted as forming by settling of silicate and sulfide liquid with PGE onto the floor of the large magma chamber. The formation of PGE-bearing stratiform complexes, such as the Archean age Bushfeld complex in South Africa (with ten producing mines in 2003), and the Archean age Stillwater complex in the USA has been intensely studied. The Norilsk-Talnakh intrusive complex in Russia (fig. 11) is a notable example of a huge PGE, nickel, and copper deposit that is hosted in a mafic and ultramafic igneous complex. However, it is much younger (early Mesozoic) than the major Archean layered complexes and is an igneous complex of magnesium- and iron-rich (mafic) plutons, dikes, and sills instead of a layered igneous complex.

Several major PGE deposits occur in the study area (table 2A, fig. 7D). Some of the major PGE deposits, where PGE is the principal commodity produced from mafic igneous rocks, are as follows: Portimo in Finland; and Alexii-Olginsky Log, Kondyor, Log No. 7, and Norilsk-Talnakh district in Russia. PGE, being a suite of very dense minerals, as is gold, are also concentrated in surficial deposits that form in active and fossil stream and beach gravels that are or were deposited downstream from lode (bedrock) PGE deposits. Examples of surficial PGE deposits in the study area are the Malaia Prostokischenka, Niasma River, Solovyevskii Log, Stepanoff Log deposits in Russia (table 2A, fig. 7D).

In Greenland, gold and palladium-rich rock layers (the Platinova Reef, fig. 24) occur in the early Cenozoic (55 million year old) Skaergaard intrusion in eastern Greenland (Mining Journal, 2000; Nielsen, 2001). The Skaergaard intrusion is a mafic (magnesium- and iron-rich) plutonic rock (gabbro). The magma that formed this intrusion is interpreted a related to a mantle plume (fig. 5) that formed the Iceland volcanic rocks. When the magma cooled and crystallized, layers of igneous rock formed that had different proportions and sizes of igneous minerals. Five of these rock layers, in a sequence called the Triple Group in the Middle Zone of the intrusion, are enriched in palladium and gold. Potential resources associated with the lowest layer (the Pd5-level) are 250 to 300 million tonnes grading 1.9 grams per tonne palladium $(2.11 \mathrm{~g} / \mathrm{t}$ platinum, palladium, and gold combined) over an area of $19 \mathrm{~km}^{2}$. The average width of the mineralized layer is $4.7 \mathrm{~m}$.

In Russia, the huge Norilsk-Talnakh PGE (nickel, copper, and cobalt) district that contains several large mines in the Norilsk-Talnakh district (fig. 11), is the most important PGE-nickelcopper districts in the world. The district contains the second largest economic concentration of nickel metal in the world, after Sudbury in Canada, and also is the largest source of copper in Russia. The PGE, nickel, and copper minerals are sulfide minerals that occur as disseminations, within and along the intrusive contacts of the mafic (magnesium- and iron-rich) and ultramafic igneous rocks, in veins, and brecciate (fractured) igneous rocks, and in masses of sulfide minerals. 
In 2003, the Norilsk-Talnakh district produced slightly more than 2002 production; unfortunately, however, absolute PGE production data are not available (Mining and Metals Company, Norilsk Nickel Annual Report, 2003). The intrusive is composed of subsurface (plutonic) mafic and ultramafic rock that intrudes late Paleozoic sedimentary rock. The intrusive is layered and extends for $12 \mathrm{~km}$ and ranges from 30 to $350 \mathrm{~m}$ thick. The host mafic and ultramafic plutonic rock age is early Mesozoic, and is associated with the extensive trap flood basalts of the same (coeval) age that crop out in extensive areas of northern and central Siberia. This and related deposits are interpreted as forming during intrusion of a mantle-derived superplume that resulted in widespread development of trap magmatism on North Asian Craton.

Also in Russia is a relatively new PGE mine in bedrock and associated placer deposits at Kondyor in the Russian Far Ear (fig. 25). This deposit is hosted in a late Mesozoic circular zoned mafic and ultramafic plutonic that is interpreted to have formed along a buried fault system (Ariunbileg and others, 2003).

In 2003, Russia produced an estimated 36,000 kilograms platinum and 74,000 kilograms palladium; about 90 percent of this production is from the huge deposit at Norilsk-Talnakh, with lesser production from the Severonickel and Pechenganickel igneous-hosted deposits on the Kola Peninsula, and from the Koryakgeoldobycha surficial (placer) PGE deposit in northern Kamchatka with production at one site of about 9,357 kilograms platinum annually (MBendi World: Mining, 2004). This placer region may have an estimated combined resource of 50 tonnes of platinum.

\section{Rare-Earth Metals, including Niobium and Tantalum}

The rare-earth metals are a group of 17 chemical elements composed of niobium, tantalum, thorium, scandium, yttrium, and the 14 lanthanide elements that originally were described as rare because they were unknown in their elemental form and were difficult to extract from ores. The principal ore minerals for rare-earth metals are bastnasite (cesium, lanthanium, carbonate, and fluorine) and monazite (cesium, lanthanium, neodymium, thorium, phosphorus, and oxygen). Rareearth metals are iron gray to silvery lustrous metals that are typically soft, malleable, and ductile, and usually reactive, especially at elevated temperatures or when finely divided. Rare-earth metals are used in a variety of applications, including catalysts for petroleum refining, glass polishing and ceramics, automotive catalytic converters, metallurgical additives and alloys, permanent magnets, phosphors for lights, televisions, computer monitors, radar, and x-ray films. The study area is a minor producer of rare-earth metals. Compared to China, that produced almost 95 percent of world production of rare-earth metals in 2003 and 2004, the Commonwealth of Independent States (Kyrgyzstan, Russia, Ukraine) only produced about 2.1 percent of world production in 2003 (table 21) (U.S. Geological Survey, 2004, 2005). The world reserve base of rare-earth metals is estimated to be about 150,000,000 tonnes. In 2003 and 2004, production occurred from major mines in China, the Commonwealth of Independent States, and Malaysia.

Table 21. Rare-earth metals - data for 2003 for world mine production, reserves, and reserve base for the study area and for the leading global producer (index mundi, 2004; U.S. Geological Survey, 2004).

\begin{tabular}{l|l|l|l|l}
\hline Country & $\begin{array}{l}\text { Percent of world } \\
\text { production, 2003 }\end{array}$ & $\begin{array}{l}\text { Rank of world } \\
\text { production }\end{array}$ & $\begin{array}{l}\text { Percent of world } \\
\text { reserves }\end{array}$ & $\begin{array}{l}\text { Percent of world } \\
\text { reserve base }\end{array}$ \\
\hline $\begin{array}{l}\text { Commonwealth of Independent States } \\
\text { (Kyrgyzstan, Russia, Ukraine) }\end{array}$ & 2.1 & 3 & 21.6 & 14.0 \\
China & 94.7 & 1 & 30.7 & 59.3
\end{tabular}

Rare-earth minerals (mainly bastnasite and monazite) occur mainly in sodium- and potassium-rich subsurface (plutonic) and volcanic rocks called alkaline igneous rocks. These rare- 
earth-bearing igneous rocks occur throughout a wide range of geologic ages from the Archean to Cenozoic. In several major localities, rare-earth-bearing igneous rocks are interpreted as forming during continental rifting in association with mantle plumes. In other areas, rare-earth minerals occur in polymetallic (igneous) vein deposits in granite in continental margin igneous arcs. A classic example of a rare-earth mineral deposit is at Gornoye Ozero in the Russian Northeast (fig. 26).

About eleven major rare-earth metal deposits occur in the study area (table 2A, fig. 7D). Some of the major deposits, where rare-earth metals are the principal commodities, are Sokli in Finland, Kringlerne in Greenland, Kundybajskoe in Kazakhstan, Aqtyuz in Kyrgyzstan, Stjernoy in Norway, Diturskoe, Lovozero, Sebl'yavr, and Tomtor in Russia, and Azovske and Yastrebets in Ukraine.

In Greenland, the major rare-earth metals deposits are associated with the Ilimaussaq carbonatite (carbonate-rich) intrusion (1,143 million year age) in southern Greenland that crops out in an ellipsoidal area, approximately $8 \mathrm{~km}$ by $17 \mathrm{~km}$ (Henriksen and others, 2000; Secher, 2002). The deposits are enriched in niobium, tantalum, zirconium, rare-earth metals, and uranium. Crystallization of the magmas led to the floating and sinking of crystals, ultimately forming rock layers enriched in one or more minerals. The major deposits are the Kringlerne deposit, and several deposits in the Agpat and Kvanefjeld areas.

Two other carbonatite complexes in Greenland are also enriched in niobium, uranium, rareearth metals, and phosphate minerals. Carbonatites are igneous rocks that contain more than 50 percent by volume carbonate minerals. Magmas that can crystallize large amounts of carbonate minerals are unusual; about 330 carbonatites are known world wide (Wooley, 1989). The two major rare-earth metal carbonatite replacement bodies are at Sarfartoq (600 million year age) in western Greenland, and in the Qaqqaarsuk complex (173 million year age) in western Greenland (Wooley, 1987; Mining Journal, 2000).

In Russia, major rare-earth metal deposits occur at Diturskoe, Lovozero, Sebl'yavr, and Tomtor (table 2A, fig. 7D). The two deposits with available reserve data are: the Diturskoe granitehosted rare-earth metal deposit with reserves of 4,138,500 tonnes ore with 162 tonnes tantalum oxide; 582 tonnes niobium oxide, 582 tonnes tin, 6,442 tonnes lithium oxide 3,876 tonnes rubidium oxide; 989 tonnes cesium; and the Lovozero sodium and potassium-rich (alkaline) granite-hosted rare-earth metal deposit with reserves of 15,000 tonnes beryllium, 200,000 tonnes yttrium, 150,000 tonnes columbium, and 150,000 t tantalum.

In Northern Central Asia, rare-earth metal deposits of niobium and tantalum are hosted in, and related to granitic plutons (subsurface igneous bodies) that occur in the Altay Mountains of Kazakhstan and Kyrgyzstan (northern Tien Shan Mountains) and in the southern Pamir Mountains of Tajikistan. The former are related to Paleozoic magmatism that occurred in a collisional event, whereas the latter are related to late Mesozoic and Cenozoic magmatism that occurred during collision in the Tethys region (Ermolov, 2000; Vladimirov and others, 2000). These deposits consist of rare-earth minerals that occur in disseminations, stockworks (vein systems), vein, and pegmatite (large crystal) bodies that are associated with sodium- and potassium-rich granite. The Verkhnee Espe and Losevskoe deposits of Kazakhstan are the best known examples. A world database of rare-earth-element deposits was published by Orris and Grauch (2002).

\section{Silver}

Silver is a white, ductile, malleable metal that has been used for thousands of years in jewelry, ornaments, and utensils, and as the basis of many monetary systems. Industrial applications of silver include: electrical and electronic products, solders, mirrors, and photography, 
which is the largest single end use of silver. Silver is useful as a catalyst. The major ore minerals for silver are silver metal, electrum (gold and silver alloy), argentite (silver sulfide), and silver halides, and in minor amounts in galena (lead sulfide) and pyrite (iron sulfide). Compared to Mexico, the major 2003 and 2004 producer of silver, the major producer for the study areawas Poland that produced 6.3 percent of world production 2003 (table 22) (U.S. Geological Survey, 2004, 2005). Over 1.7 million tonnes of silver have been discovered (Singer, 1995) and the world reserve base of silver is estimated to be about 570,000 tonnes. In 2003, the total silver production was estimated at 19,000 tonnes. In 2003 and 2004, production occurred from major mines in Australia, Canada, Chile, China, Mexico, Peru, Poland, and the United States (U.S. Geological Survey, 2004, 2005).

Table 22. Silver - data for 2003 for world mine production, reserves, and reserve base for the study area and for the leading global producer (U.S. Geological Survey, 2004).

\begin{tabular}{l|l|l|l|l}
\hline Country & $\begin{array}{l}\text { Percent of world production, } \\
2003\end{array}$ & $\begin{array}{l}\text { Rank of world } \\
\text { production }\end{array}$ & $\begin{array}{l}\text { Percent of world } \\
\text { reserves }\end{array}$ & $\begin{array}{l}\text { Percent of world reserve } \\
\text { base }\end{array}$ \\
\hline Poland & 6.3 & 8 & 28.8 & 24.6 \\
Mexico & 14.7 & 1 & 13.6 & 7.0
\end{tabular}

More than two-thirds of world silver resources are spatially associated with copper, lead, and zinc hydrothermal and igneous deposits (figs. 5, 12). The remainder are associated with hydrothermal (epithermal) gold deposits such as at the Dukat mine in the Russian Northeast (fig. 13).

Over 80 major deposits with silver as the primary or an important secondary commodity occur in the study area (table 2A, fig. 7E). Some of the major deposits, where silver is the principal commodity, or where significant silver production is recorded, are as follows: Black Angel sedimentary deposit in Greenland; and the Aginskoe, Asachinskoe, Berezitovoe, Burindinskoe, Julietta, Dukat, Khakandzhinskoe, Khotoidokh, and Mangazeika 1 hydrothermal vein deposits, Kupol'noe tin granite deposit, and the Lunnoe 1, Prognoz and Zarechenskoye hydrothermal vein deposits in Russia.

In Europe, major silver mining and production of spectacular silver mineral crystals has occurred in several countries, including the following: in the United Kingdom, a number of Cornish localities, including Alfred, Anne, Basset, Duchy, Golden Herland, Tremayne, and Wheal Vincent in England; Alva in Scotland; Les Chalanches Haute-Rhin, and Sainte-Marie-aux in France; Balcoll, Guadalajara, Hiendelaencina district, San Andres, and Tarragona in Spain; Annaberg, Buskerud, Harz Mountains, Hirsch, Johanngeorgenstadt, Kongsberg, Niedersachsen, Schneeberg Sauschwart, Schneeberg, Saint Andreasberg, and Weisser in Germany; Garpenberg in Sweden; Pribram, Saint Joachimsthal, and Zvezdel in the Czech Republic; East Rhodope Mountains in Bulgaria; Monte Narba, Sarrabus, and Sardinia in Italy; and Schemnitz in Romania.

Poland accounted for just over six percent of the world production (U.S. Geological Survey, 2004), mainly from sedimentary copper deposits with silver as a by-product. These mines include the Lubin and Borzecin/Sulmierzyce mines (table 2A, fig. 7E) and the KGHM Polska Miedz mine. Twelve other countries in Europe also produce silver but in small amounts.

In Russia, the Aginskoe, Asachinskoe, Burindinskoe, Julietta, Dukat, Khakandzhinskoe, Khotoidokh, and Mangazeika 1 hydrothermal vein deposits have produced substantial silver or contain major silver reserves (Ariunbileg and others, 2003). These deposits are mainly hydrothermal (shallow-level epithermal vein) types (fig. 13) that formed near the surface of the modern Kurile-Kamchatka volcanic arc in the Russian Far East (fig. 3), or in older, up to late Mesozoic continental margin arcs in eastern Russia. The hydrothermal vein deposits with major 
production or substantial reserves are the Aginskoe with estimated reserves of 10 to 20 tonnes silver, Burindinskoe deposit with an estimated reserves of 38,200 kg silver, Dukat deposit with an estimated reserves of 10,000 tonnes silver, and Julietta deposit with estimated reserves of 200 tonnes silver. Other deposit types with substantial reserves or production are: Berezitovoe hydrothermal (polymetallic) vein deposit with reserves of estimated 200 tonnes silver; Khotoidokh hydrothermal (volcanic massive sulfide) deposit with a resource of about 1,000 tonnes silver; Mangazeika 1 hydrothermal (polymetallic) vein deposit with reserves of more than 1,000 tonnes silver; Prognoz hydrothermal (polymetallic) vein deposit with reserves of more 2,000 tonnes silver; Salairskoye hydrothermal (polymetallic) vein deposit with reserves of more 200 tonnes silver; Shkolnoe hydrothermal (granitoid-related) deposit with production of more than 17 tonnes silver; and Zarechenskoye hydrothermal (volcanic massive sulfide) deposit with a resource of about 432 tonnes silver.

Russia was the world's ninth largest silver producer in 2003, producing 33.8 million ounces in 2003 (MBendi World: Mining, 2004). The rise is the result of the start of mining at the Lunnoye silver-gold deposit in the Russian Northeast. Russia's biggest silver-producing regions are the Krasnoyarsk territory, Bashkortostan and Chelyabinsk region, Orenburg region, and Primorye region. More than 90 percent of silver in Russia is produced as a byproduct of nonferrous metals production with the Norilsk-Talnakh district being one of the country's largest producers. The only primary silver deposit that has been explored in detail is the Dukat mine in the Russian Northeast that is projected to produce a large percentage of Russia's silver. This deposit contains an estimated 14.3 million tonnes grading 655 grams per tonne silver and 1.39 grams per tonne gold. In the same region, about 3.49 tonnes gold and about 44 tonnes silver were produced at the Julietta mine in 2002. In the Primorye region, the Maiminovskoye silver hydrothermal (polymetallic vein) deposit is estimated to contain 20 million tonnes ore averaging 250 grams per tonne silver.

In Northern Central Asia, silver, and related gold, antimony, and mercury deposits occur in geologic environments similar to copper deposits related to granitic rocks, but are located in peripheral volcanic rocks. These types of deposits occur both in middle and late Paleozoic island arc belts in the Altay Mountains and in the Mesozoic and Cenozoic units in Tethys belts in the Caucasus Mountains. These deposits can be mined by either open pit or underground methods. An example of this type of deposit is the Kochbulack deposit in Uzbekistan (100 tonnes of gold, 400 tonnes of silver) (Shayakubov and others, 1999).

Tin

Tin is a silvery-white metallic element that is used predominantly in tinplate for tin cans. It also is used to make a variety of alloys, such as brass, bronze, and solder. Tin is derived mainly from the mineral cassiterite (tin and oxygen). Tin mostly occurs in hydrothermal (igneous-related) tin vein, tin replacement (skarn), or in altered granite (greisen) deposit types, and derivative placer (surficial) deposits that are associated mostly with igneous rocks in continental margin igneous arcs (fig. 5). Compared to the China, the major 2003 and 2004 producer of tin, Portugal and Russia, the major producers for the study area, produced about 25 percent of world production in 2003 (table 23) (U.S. Geological Survey, 2004, 2005). The world reserve base of tin is estimated to be about $11,000,000$ tonnes. In 2003, the total tin production was estimated at 265,000 thousand tonnes. In 2003 and 2004, production occurred from major mines in Australia, Bolivia, Brazil, China, Indonesia, Malaysia, Peru, Portugal, Russia, Thailand, and the Vietna (U.S. Geological Survey, 2004, 2005). 
Table 23. Tin - data for 2003 for world mine production, reserves, and reserve base for the study area and for the leading global producer (U.S. Geological Survey, 2004).

\begin{tabular}{l|l|l|l|l}
\hline Country & $\begin{array}{l}\text { Percent of world production, } \\
2003\end{array}$ & $\begin{array}{l}\text { Rank of world } \\
\text { production }\end{array}$ & $\begin{array}{l}\text { Percent of world } \\
\text { reserves }\end{array}$ & $\begin{array}{l}\text { Percent of world reserve } \\
\text { base }\end{array}$ \\
\hline Portugal & 24.5 & 11 & 11.8 & 9.0 \\
Russia & 0.8 & 9 & 5.0 & 3.1 \\
China & 33.9 & 1 & 28.2 & 31.4
\end{tabular}

About 30 major tin deposits occur in the study area (table 2A, fig. 7E). Some of the major tin deposits, where tin is the principal or a major secondary commodity, are the Krasno hydrothermal deposit in the Czech Republic, Altenberg hydrothermal deposit in Germany, Belogorskoe igneous (large crystal or pegmatite), Donetskoe and Syrymbet greisen (altered granite) and Uchkoshton granite hosted tin deposits in Kazakhstan, Neves-Corvo and Panasqueira hydrothermal deposits in Portugal, Arsenyevsky, Deputatskoe, Iultin, Kukenei, Sherlovogorskoe, Svetloe, Valkumei, and Vysokogorskoe tin vein deposits in Russia, Pyrkakai granite-hosted tin deposit in Russia, Aqarkhar tin hydrothermal replacement (skarn) deposit in Tajikistan, Geevor, Hemerdon, South Crofty, and Wheal Jane hydrothermal deposits in the Cornwall district, England, and Ingichke tin and tungsten deposit hydrothermal replacement (skarn) deposits in Uzbekistan.

Russia is the world's eight largest tin concentrate producer (MBendi World: Mining, 2004). Although claiming to have the world's third largest tin reserves, Russian grades are significantly lower (0.4 percent tin) compared to other global deposits. Tin is produced from the eastern parts of Russia from both placer and lode deposits, with production dominated by the Novosibirsk Tin Combine. The major producing mines in the Sakha (Yakutia) Republic in the Russian Far East are at Dalolovo, Deputatskolovo, Khinganolovo, Trudovoye, and Vostokolovo. In eastern Russia, the majority of the deposits occur in hydrothermally-altered granite (greisen) or tin veins that are associated with continental margin igneous arcs of late Mesozoic to early Cenozoic age that formed adjacent to the ancestral Pacific Ocean (Ariunbileg and others, 2003; Nokleberg and others, 2003). The only tin deposits with published reserve data is the Boguchanskoe greisen deposit with reserves of 3,000 tonnes tin (Ariunbileg and others, 2003).

In Northern Central Asia, tin and tungsten deposits related to granitic intrusions (so-called tin-tungsten greisen (altered granite), tin vein, and tin hydrothermal (skarn) deposits) occur primarily in the Altay Mountains of Kazakhstan. These deposits occur as disseminations, vein stockworks, vein, or hydrothermal (skarn) deposit either in, or adjacent to granitic intrusions. These deposits may also contain significant molybdenum. The Donetskoe deposit (125,000 tonnes of tin) and (82,900 tonnes of tungsten oxide), and Koktenkol deposit (430,000 tonnes molybdenum, 62,000 tonnes tungsten oxide) are two significant deposits (Seltmann and others, 2003). A more thorough description of tin and tungsten deposits related to granite intrusion in the Central Asian region is by Kremenetsky and others (2000).

\section{Titanium}

Titanium is a hard silvery-white, corrosion-resistant metal that is quite important in military and special applications, such as aerospace, armor, and sporting goods because of its low density and exceptional strength. Two minerals are mined worldwide for titanium, ilmenite (iron, titanium, and oxygen), and rutile (titanium and oxygen), with ilmenite mined at a rate ten times higher than rutile. Both ilmenite and rutile are accessory minerals as primary deposits in magnesium- and ironrich (mafic) igneous rock (granite) to siliceous-rich igneous rock (granite). The two minerals are 
generally obtained from surficial (placer or secondary) deposits that form from the weathering of gabbro to granite.

Titanium combines with oxygen to form a variety of oxide minerals. Titanium dioxide is one of the chemical compounds derived from these minerals and the world's premier white pigment in the coatings, paper, and plastics industries, which accounts for nearly all of its industrial applications. Titanium dioxide is non-toxic and biologically inert, so it also is used for coloring in foodstuffs like flour, icing sugar, sweets, cosmetics, and toothpaste. Titanium metal is strong yet lightweight. About 65 percent of titanium metal is used in aerospace applications; the remaining 35 percent is used in medical, sporting goods, and other applications. Ilmenite (iron titanium trioxide) supplies about 90 percent of the world's demand for titanium most of which is used for pigment for paints.

Compared to the Australia, the major 2003 amd 2004 producer of ilmenite, Norway and Ukraine, the major producers for the study area, produced about 13 percent of world production in 2003 (table 24) (U.S. Geological Survey, 2004, 2005). The world reserve base of ilmenite and rutile is estimated to be about 1300,000 tonnes for ilmenite and 140,000 tonnes for rutile (U.S.

Geological Survey, 2005). Identified world resources of other titanium minerals total about 2 billion tonnes of contained titanium dioxide. In 2003, production occurred from major ilmenite and rutile deposits in Australia, Canada, India, Norway, South Africa, Ukraine, and the United States (U.S. Geological Survey, 2004, 2005). The ready availability of titanium in a wide and ever increasing range of products forms has assured its growth as a basic general engineering material (MBendi World: Mining, 2004).

Table 24. Titanium mineral concentrate (ilmenite) - data for 2003 for world mine production, reserves, and reserve base for the study area and for the leading global producer (U.S. Geological Survey, 2005).

\begin{tabular}{l|l|l|l|l}
\hline Country & $\begin{array}{l}\text { Percent of world production, } \\
2003\end{array}$ & $\begin{array}{l}\text { Rank of world } \\
\text { production }\end{array}$ & $\begin{array}{l}\text { Percent of world } \\
\text { reserves }\end{array}$ & $\begin{array}{l}\text { Percent of world reserve } \\
\text { base }\end{array}$ \\
\hline Norway & 7.3 & 4 & 5.6 & 4.6 \\
Ukraine & 5.9 & 6 & 0.9 & 1.0 \\
Australia & 23.9 & 1 & 30.3 & 19.2
\end{tabular}

Table 25. Titanium mineral concentrate (rutile) - data for 2003 for world mine production, reserves, and reserve base for the study area and for the leading global producer (U.S. Geological Survey, 2005).

\begin{tabular}{l|l|l|l|l}
\hline Country & $\begin{array}{l}\text { Percent of world production, } \\
2003\end{array}$ & $\begin{array}{l}\text { Rank of world } \\
\text { production }\end{array}$ & $\begin{array}{l}\text { Percent of world } \\
\text { reserves }\end{array}$ & $\begin{array}{l}\text { Percent of world reserve } \\
\text { base }\end{array}$ \\
\hline Ukraine & 15.0 & 3 & 4.6 & 1.8 \\
Australia & 43.2 & 1 & 40.7 & 26.2
\end{tabular}

Economic titanium deposits can be formed during the crystallization of igneous rocks. Such deposits are called primary deposits. Secondary placer deposits are formed when primary deposits $\backslash$ are reworked and concentrated by weathering and sedimentary processes (fig. 20). In primary titanium deposits, concentrations of titanium-enriched minerals form during the crystallization of granitic magma (Gross, 1996b). The titanium-bearing minerals can crystallize directly from magma as crystals of titanium oxides and be concentrated into layers or zones in the cooled and crystallized igneous rocks. In contrast, secondary (surficial or placer) deposits form as titanium-rich minerals are weathered from rocks and are transported and concentrated by streams, rivers, and ocean currents. Titanium-enriched minerals are heavier than other minerals. Consequently, flowing water will concentrate these and other minerals (like gold) as placer deposits in sediments, particularly in 
coastal environments (Harben and Kužvart, 1996). Titanium also occurs as primary minerals in sedimentary iron deposits called banded iron formation.

About 15 major titantium deposits occur in the study area (table 2A, fig. 7D). Some of the titanium deposits, where titanium is the principal commodity, are as follows: Otanmaki igneous deposit in Finland; Piampaludo metamorphic deposit in Italy; Druzhba A and B, and Kumkol'skoe, and Singirbajskaja surficial deposits in Kazakhstan; Tellnes igneous deposit in Norway; Chituc surficial deposit in Romania; Glogova-Sisesti igneous deposit in Romania; Ariadnoe, GremyakhaVyrmes, Gusevogorsk, and Kavakta igneous deposits in Russia; Malyshevskiy surficial deposit in Russia; and the Vilnohirsk surficial deposit in Ukraine. 1998, the Ukraine was the world's 3rd largest producer of rutile (after Australia and South Africa) and the ninth largest ilmenite producer (MBendi World: Mining, 2004).

Russia does not have any primary titanium mines (MBendi World: Mining, 2004). The major titanium deposits, for which reserve or production data are available, are as follows. The Gusevogorsk igneous deposit, that is hosted in a late Paleozoic gabbro pluton, has produced substantial ore with an average grade of 1.15 percent titanium dioxide (Kirkham and Rafer, 2003). The Kharlovskoye igneous deposit, that is also hosted in a in a middle to late Paleozoic zoned mafic (magnesium- and iron-rich) to ultramafic pluton, has reserves of 1.7 billion tonnes titanium dioxide (Ariunbileg and others, 2003). Currently, Russia does not have any operating mines (MBendi World: Mining, 2004).

\section{Tungsten}

Tungsten is a gray-white metallic element that has the highest melting temperature of all elements except carbon, and has many physical and chemical characteristics. It has the highest melting point of all elements except carbon, is one of the heaviest metals, and has an extremely high conductivity. Tungsten is used in cemented carbide parts for cutting and wear-resistant materials primarily in the construction, gas and oil drilling industries, metalworking, and mining. Some tungsten also is used to make chemicals for catalysts and pigments, electrodes and other components for the electric and electronic industries, lamp filaments, and steels. Only two tungsten-bearing minerals are important economically, wolframite (iron, manganese, tungsten, and oxygen) and scheelite (calcium, tungsten, and oxygen). Economic grades of tungsten vary between 0.3 and 1 percent tungsten trioxide. Most tungsten production is from hydrothermal alteration (skarn) deposits; however some tungsten deposits occur in veins or altered granite (W-Mo-Be greisen), stockworks (vein networks), and quartz veins along with tin and (or) molybdenum.

Compared to the China, the major 2003 and 2004 producer of tungsten, Austria, Portugal and Russia, the major producers for the study area, produced about 9.3 percent of world production in 2003 (table 26) (U.S. Geological Survey, 2004, 2005). The world reserve base of tungsten is estimated to be about 6.2 million tonnes. In 2003, the total tungsten production was estimated at 62,100 tonnes. In 2003, production occurred from major mines in Australia, Bolivia, Canada, China, Korea, Portugal, Russia, and the United States (U.S. Geological Survey, 2004). The major world tungsten producers are China, Confederation of Independent States, and Austria (MBendi World: Mining, 2004). 
Table 26. Tungsten - data for 2003 for world mine production, reserves, and reserve base for the study area and for the leading global producer (U.S. Geological Survey, 2004).

\begin{tabular}{l|l|l|l|l}
\hline Country & $\begin{array}{l}\text { Percent of world production, } \\
2003\end{array}$ & $\begin{array}{l}\text { Rank of world } \\
\text { production }\end{array}$ & $\begin{array}{l}\text { Percent of world } \\
\text { reserves }\end{array}$ & $\begin{array}{l}\text { Percent of world reserve } \\
\text { base }\end{array}$ \\
\hline Austria & 2.4 & 4 & 0.3 & 0.2 \\
Portugal & 1.2 & 5 & 0.9 & 0.2 \\
Russia & 5.7 & 2 & 8.6 & 6.8 \\
China & 83.2 & 1 & 62.1 & 68.0
\end{tabular}

Almost all tungsten production for the study area is from hydrothermal alteration (skarn) deposits (fig. 5). Skarn is a coarse-grained mixtures of ore minerals and calcium-and silicon-rich minerals. The deposits commonly occur at the boundary between igneous rocks and calcium-rich sedimentary rocks like limestone. Skarn deposits form where hydrothermal fluids derived from magmas react with calcium-rich sedimentary rocks. The magmas that form such deposits are part of magmatic arcs that form in response to the subduction of convergent tectonic plates (fig. 5). This setting is analogous to the one described for porphyry copper deposits; however, tungsten skarns form at deeper levels in the Earth's crust and at higher temperatures.

About 40 major tungsten deposits occur in Greenland, Europe, Russia, and Northern Central Asia, mainly in Austria, Finland, France, Kazakhstan, Kyrgyzstan, Russia, Spain, Sweden, Tajikistan, United Kingdom, and Uzbekistan (table 2A, fig. 7E). In Greenland, Europe, Russia, and Northern Central Asia, only sparse production or reserve data are published. Some of the tungsten deposits, where tungsten is the principal commodity, and for which production or reserve data are available, are as follows: Verkhnee Qairaqty tungsten vein deposit in Kazakhstan with reserves of 1.1 million tonnes of tungsten metal (Seltmann and others, 2003); Barun-Shiveinsky hydrothermal alteration deposit in Russia with resources of up to 5,000,00 tonnes tungsten trioxide (Ariunbileg and others, 2003); Belukha hydrothermal skarn deposit in Russia with reserves of 1,181,000 million tonnes ore (McFaul and others, 2000); Boguchanskoe hydrothermal skarn deposit in Russia with reserves of 21,000 tonnes tungsten trioxide (McFaul and others, 2000); Bom-Gorkhon hydrothermal skarn deposit in Russia with reserves of 400,000 million tonnes ore (McFaul and others, 2000); Dzhida hydrothermal vein deposit in Russia with reserves of 10.9 million tonnes ore (McFaul and others, 2000); Kalgutinskoye 1 hydrothermal alteration deposit in Russia with reserves of 12,000 tonnes tungsten trioxide (Ariunbileg and others, 2003); Kti-Teberda hydrothermal vein deposit with reserves of 475,000 million tonnes ore (McFaul and others, 2000); Lednikovy-Sarmaka Teberda hydrothermal vein deposit with reserves of 41,000 tonnes tungsten trioxide (Ariunbileg and others, 2003); Tyrnyauz hydrothermal alteration and skarn deposit in Russia with reserves of about 50,800,000 metric tonnes (Kirkham and Rafer, 2003).

In Europe, tungsten is mined at the hydrothermal Mittersill deposit in Austria and as a coproduct from the hydrothermal Panasqueira deposit in Portugal. Both deposits account for between three and four percent of the world production (U.S. Geological Survey, 2004).

Kyrgyzstan has impressive reserves of tin and tungsten, mostly in the Sary-Dzhaz river basin in eastern Kyrgyzstan. The deposit is estimated to contain over 150,000 tonnes tin and 90,000 tonnes tungsten. Tungsten reserves total 386,000 tonnes of tungsten trioxide at Trudovoye and Kensu, 1,565 tonnes at Meliksu, Kashkasu and Sargardon, and 10,900 tonnes at Kindyk, Meliksu and Kashkasu (MBendi World: Mining, 2004).

In Russia, nearly half of Russia's tungsten reserves occur in the North Caucasus Mountains, with remaining reserves in the Russian Far East and eastern Siberia (MBendi World: Mining, 2004). The Tyrnyaus complex is the North Caucasus Mountains and is Russia's largest tungsten 
producer. The complex has low-grade reserves estimated at containing 375 million tonnes ore. Other major mines include the Primorskiy and Lermontov deposits in the Russian Far East.

Uzbekistan contains some of the largest tungsten reserves in the Confederation of Independent States (MBendi World: Mining, 2004). The Ingitchke and Koytash deposits are nearly exhausted. The Sautbay deposit, undergoing development, has estimated reserves of 17,000 tonnes tungsten.

In Northern Central Asia, tin and tungsten deposits related to granite intrusions (so-called tin-tungsten greisen, vein, and skarn deposits) occur primarily in the Altay Mountains (fig. 3) of Kazakhstan. These deposits occur in disseminations, stockworks, veins, or skarns that are located in, or adjacent to the granite intrusion. These deposits may also contain significant amounts of molybdenum. The Donetskoe deposit (125,000 tonnes of tin) and (82,900 tonnes of tungsten trioxide) and Koktenkol deposit (430,000 tonnes of molybdenum, 62,000 tonnes of tungsten trioxide) are two of the more significant deposits of this type in the region (Seltmann and others, 2003). A more thorough description of tin and tungsten deposits related to granitic intrusion in the Central Asian region is published by Kremenetsky and others (2000).

\section{Industrial Minerals}

\section{Asbestos}

Asbestos refers to a small number of minerals that form as flexible fibers and have the useful physical property of being very heat and fire resistant. Asbestos is used mainly in gaskets and roofing shingles. Asbestos mineral fibers are flexible and can be woven to make fabrics for heat-resistant and insulating materials. Asbestos occurs mainly in highly-altered and (or) metamorphosed ultramafic (magnesium- and iron-rich) igneous rock that is very mafic (rich in magnesium and iron). The current use of asbestos are affected by liability issues and public environment opposition.

Russia was the major 2003 and 2004 producer of asbestos and together with Kazakhstan produced almost 50 percent of world production in 2003 (table 27) (U.S. Geological Survey, 2004, 2005). In 2003, the total asbestos production was estimated at 2,060 thousand tonnes. The world has about 200 million tonnes of identified asbestos (U.S. Geological Survey, 2004). In 2003 and 2004, production occurred from major mines in Brazil, Canada, China, Kazakhstan, Russia, Zimbabwe, and the United States (U.S. Geological Survey, 2004, 2005).

Table 27. Asbestos - data for 2003 for world mine production, reserves, and reserve base for the study area and for the leading global producer (U.S. Geological Survey, 2004).

\begin{tabular}{l|l|l|l|l}
\hline Country & $\begin{array}{l}\text { Percent of world production, } \\
2003\end{array}$ & $\begin{array}{l}\text { Rank of world } \\
\text { production }\end{array}$ & $\begin{array}{l}\text { Percent of world } \\
\text { reserves }\end{array}$ & $\begin{array}{l}\text { Percent of world reserve } \\
\text { base }\end{array}$ \\
\hline Kazakhstan & 12.1 & 4 & Large & Large \\
Russia & 36.4 & 1 & Large & Large
\end{tabular}

Asbestos deposits typically are associated with magnesium-rich igneous rocks and metamorphic rocks typically found in the Earth's upper mantle (figs. 4, 5). These rocks represent fragments of oceanic crust that were emplaced into continental crust during the collision of convergent tectonic plates (fig. 5). The rocks were broken and heated during the collision; hydrothermal fluids generated during this event moved through and chemically altered the rocks. Asbestos minerals grew in fractures and faults during this alteration process. 
Only about 6 major asbestos deposits occur in the study area (table 2B, fig. 8A). Some of the major asbestos deposits, where asbestos is a principal or major secondary commodity, are as follows: Zidani hydrothermal deposit in Greece; Belangero hydrothermal deposit in Italy; the Aktovrakskyoe (Tura), Bugetysajskoe, Dzhetygarinskoe, Eshkeul'messkoe, and Kiembayskoye in Russia, and the Bazhenovo group of metamorphic deposits in the Urals Mountains in southern Russia and northern Kazakhstan. The Bazhenovo metamorphic deposit in southern Siberia is a stockwork-type asbestos deposit. The deposit consists of chrysotile-type asbestos in ultramafic (magnesium- and iron-rich) rock that is intruded by granite.

\section{Barite}

Barite is a relatively soft mineral composed of barium and sulfur. It is chemically inert and insoluble and is unusually heavy. These properties are responsible for its value in many applications. Nearly 98 percent of the barite used in the United States is used as a weighting agent in oil- and gas-well drilling fluids. Because barite looks opaque on X-ray film, it is used in medicine to diagnose gastrointestinal problems. It is also used in devices to protect humans from $\mathrm{x}^{-}$ rays and radiation, such as screens in televisions and computer monitors. Barite is a common mineral in veins that form from hydrothermal solutions and in bedded layers in sedimentary rock as chemical precipitates on the sea floor (fig. 5). Compared to the China, the major 2003 and 2004 producer of barite, Germany, France, and Russia, the major producers for the study area, produced about 3.9 percent of world production in 2003 (table 28) (U.S. Geological Survey, 2004, 2005). The world reserve base of barite is estimated to be about 740,000 thousand tonnes. The world's barite resources are about 2 billion tonnes. In 2003 and 2005, production occurred from major mines in China, Germany, India, Iran, Kazakhstan, Mexico, Morroco, Turkey, and the United States (U.S. Geological Survey, 2004, 2005).

Table 28. Barite - data for 2003 for world mine production, reserves, and reserve base for the study area and for the leading global producer (U.S. Geological Survey, 2004).

\begin{tabular}{l|l|l|l|l}
\hline Country & $\begin{array}{l}\text { Percent of world production, } \\
\text { 2003 }\end{array}$ & $\begin{array}{l}\text { Rank of world } \\
\text { production }\end{array}$ & $\begin{array}{l}\text { Percent of world } \\
\text { reserves }\end{array}$ & $\begin{array}{l}\text { Percent of world reserve } \\
\text { base }\end{array}$ \\
\hline Germany & 1.9 & 7 & 0.5 & 0.2 \\
France & 1.1 & 9 & 1.0 & 0.3 \\
Russia & 0.9 & 11 & 1.0 & 0.4 \\
China & 52.3 & 1 & 31.1 & 48.5
\end{tabular}

Barite occurs in many deposits in Europe, but is the principle commodity in only a few of those deposits. About three major barite deposits occur in the study area (table 2B, fig. 8A). The major barite deposits, for which published data are available, are as follows: Ljubija sedimentary deposit in Bosnia-Herzegovina; Chaillac sedimentary deposit in France; and the Chaillac hydrothermal deposit in Germany, and the Parkside Mine in the United Kingdom. No production or reserve data are available for these deposits.

\section{Boron}

Boron is a semimetallic element that is a dark, amorphous (noncrystalline), nonreactive solid. Boron is mined and used principally as a variety of borate minerals and compounds composed mostly of boron and oxygen in combination with sodium, calcium, and magnesium. Borates have a wide variety of uses, including the manufacture of glass, ceramic glazes, fertilizers, fire retardants, and soaps and detergents. Compared to the Turkey, the major 2003 and 2004 
producer of boron, Russia, the major producer for the study area, produced about 23 percent of world production in 2003 (table 29) (U.S. Geological Survey, 2004, 2005). The world reserve base of boric oxide is estimated to be about 410,000 thousand tonnes boric oxide. In 2003, the total boric oxide production was estimated at 4,350 thousand tonnes (U.S. Geological Survey, 2004). In 2003 and 2004, production occurred from major mines in Argentina, Chile, China, Russia, Turkey, and the United States (U.S. Geological Survey, 2004, 2005).

Table 29. Boron - data for 2003 for world mine production, reserves, and reserve base for the study area and for the leading global producer (U.S. Geological Survey, 2004).

\begin{tabular}{l|l|l|l|l}
\hline Country & $\begin{array}{l}\text { Percent of world production, } \\
2003\end{array}$ & $\begin{array}{l}\text { Rank of world } \\
\text { production }\end{array}$ & $\begin{array}{l}\text { Percent of world } \\
\text { reserves }\end{array}$ & $\begin{array}{l}\text { Percent of world reserve } \\
\text { base }\end{array}$ \\
\hline Russia & 23.0 & 3 & 23.3 & 24.4 \\
Turkey & 34.5 & 1 & 34.9 & 36.7
\end{tabular}

Borate deposits occur mainly in Cenozoic sediments that were deposited in nonmarine lakes. These lakes are usually spatially and genetically associated with boron-rich springs, sedimentary basins, and contemporaneous volcanism. Late-stage hydrothermal waters from the volcanism, as well as leaching boron from the volcanic rocks by weathering, supplied the boron. In the Russian Far East, a very unusual boron hydrothermal alterations (skarn) deposit at Dalnegorsk (fig. 27) is associated with early Cenozoic granite (Nokleberg and others, 2003). Three major boron deposits occur in the study area (table 2B, fig. 8D). The major boron deposits, for which published data are available, are as follows: Inderskoe and Shalkarskoe sedimentary deposits in Kazakhstan that consist of boron and fluorite in gypsum and salt caps in salt domes thare are upwellings of saltrich sedimentary strata (Natapov and others, 2000); and the Dalnegorsk boron world class hydrothermal alteration (skarn) deposit that produces over 90 percent of all borate in Russia (fig. 27) (Ariunbileg and others, 2003).

\section{Clay (Kaolin, Bentonite, and Fuller's Earth)}

The clay minerals are a complex group of layered minerals that form by the hydrothermal alteration of rocks by natural acidic solutions and by the weathering and erosion of rocks with the resultant clays forming residual deposits in place, or as sediments in sedimentary basins. The three major industrial clay minerals are kaolin, bentonite, and Fuller's earth. Kaolin, the principal industrial clay mineral, is a term for a group of clay that includes commercial varieties (or subgroups) such as ball clay, halloysite, kaolin, and refractory or flint clay. Although best known as the main component in porcelain and other ceramics, kaolin has diverse uses in the production of paper, refractories, cosmetics, bricks, and drain tiles. Many of its uses are determined by its whiteness and chemical composition. Other common clay minerals are bentonite and Fuller's earth. Kaolin and bentonite are produced in the study area in 2003; however, Fuller's earth was not produced in major amounts in the study area in 2003 (U.S. Geological Survey, 2004). In 2003 and 2004, production of clay minerals occurred from major mines in the Commonwealth of Independent States, Czech Republic, Greece, Italy, Mexico and Turkey.

The Commonwealth of Independent States was the major 2003 and 2005 producer of kaolin. Other producers for the study area include the Czech Republic, Greece, the United Kingdom, and Italy that together produced about 14.1 percent of world production in 2003 (table 30) (U.S. Geological Survey, 2004, 2005). Five countries in Europe account for about 31.9 percent of world kaolin production. 
Table 30. Kaolin - data for 2003 for world mine production, reserves, and reserve base for the study area and for the leading global producer (U.S. Geological Survey, 2004).

\begin{tabular}{l|l|l}
\hline Country & Percent of world production, 2003 & Rank of world production \\
\hline Czech Republic & 8.8 & 4 \\
Greece & 0.2 & 10 \\
Commonwealth of Independent States & 17.7 & 1 \\
Italy & 0.2 & 10
\end{tabular}

Greece was the major 2003 and 2004 producer of bentonite. Other countries in the study area, including the Commonwealth of Independent States, the Czech Republic, and Italy, produced about 8.6 percent of world production in 2003 (table 31) (U.S. Geological Survey, 2004, 2005).

Table 31. Bentonite - data for 2003 for world mine production, reserves, and reserve base for the study area and for the leading global producer (U.S. Geological Survey, 2004).

\begin{tabular}{l|l|l}
\hline Country & Percent of world production, 2003 & Rank of world production \\
\hline Greece & 11.9 & 1 \\
Commonwealth of Independent States & 7.4 & 3 \\
Italy & & \\
Czech Republic & 1.2 & 8
\end{tabular}

For Fuller's earth, only Italy produced a small amount, about 0.7 percent of the world mine production.

The world reserve base for clay is estimated as large in major producing countries; however, data are not available. Major clay (bentonite, Fuller's earth, and kaolin) producers are Commonwealth of Independent States, Czech Republic, Greece, Italy, Korea, Mexico, Turkey, and the United States (U.S. Geological Survey, 2004).

About 12 major kaolin deposits occur in the study area (table 2B, fig. 8A). The major kaolin deposits, for which published data are available, are as follows: Horní Bríza, Karlovy Vary, Kaznejov, and Podborany surficial deposit in Czech Republic; Friedland and HirschauSchnaittenbach sedimentary deposit in Germany; Novorayskoe and Oktyabrskoye sedimentary deposit in Ukraine; Bodmin Moor, Bovey Basin, Lee Moor, and St. Austell hydrothermal deposits in United Kingdom. Kaolin deposits probably occur in other the study area countries; however, published data are not available.

\section{Diamond (industrial)}

Diamond is a mineral composed of crystalline carbon that forms at extremely high temperature and pressure conditions that are possible only very deep in the Earth's upper mantle. Large diamonds without flaws are rare and are very valuable as gemstones. The vast majority of diamonds, however, are small, flawed, and colored by dark impurities. These small impure diamonds have a variety of industrial uses, particularly as abrasives to coat saw blades for stone cutting and highway building. Because of beauty and physical characteristics, diamond has been regarded as a symbol of love, beauty and eternity (MBendi World: Mining, 2004). The mines in the Sakha (Yakutia) Republic of Russia produce a high proportion of gemstone diamonds.

Although the principal use of diamonds is in jewelery, not all diamonds are of gem quality. Nost diamond deposits contain a varying proportion of industrial and gem quality stones. Industrial diamonds comprise about 60 percent of global production by weight, and are used mainly in abrasives lens manufacture and wire drawing in electrical circuits. Originally crushed diamonds 
were used for these purposes; however synthetic diamonds are now being produced in laboratories and pose a threat to the industrial diamond mine production globally. Synthetic diamonds are utilized for more than 90 percent of industrial applications. Russia, Botswana ,and South Africa are the world's major gem quality diamond producers, with Australia being a major industrial diamond producer.

Diamond deposits occur in either igneous rock or surficial deposits (table 3). Igneous deposits with diamond generally occur in rare and unusual mantle-derived rocks called kimberlite (fig. 28). Kimberlites typically occur in the roots of volcanic pipes. Surficial deposits form by the weathering of the igneous deposits and transportation of diamonds by water into streams or ocean beaches. About 90 percent of diamond production comes from igneous deposits.

Carbon crystallizes to form diamond in rocks in the mantle (fig. 4) at about 150 to $200 \mathrm{~km}$ below the Earth's surface. Above that depth, carbon, the metallic element that comprises diamond, occurs in the mineral graphite. Diamonds are foreign to kimberlite pipes in which they are mined (DeBeers, 2004; Mitchell, 1986, 1993). Small, explosive magmatic eruptions that feed surface volcanoes, bring the kimberlite, possibly containing diamonds, from the mantle into the pipes. As the magma approaches the Earth's surface, gases in the magma expand and erupt, forming a carrotshaped explosion pipe filled with kimberlite (fig. 28).

Kimberlites generally are restricted to the oldest continental crust in the Archean age shields in the cores of continents. For reasons that are unclear, particular regions have been the loci for repeated cycles of kimberlitic magmatism. Kimberlite pipes tend to occur in clusters forming fields and provinces, and locally, their distribution is controlled by fracture and fault zones. Only a small proportion of known kimberlites contain diamonds. Diamonds also occur in surficial deposits (placers) that are generally related to bedrock deposits, and to a lesser extent in sedimentary rock. A rare, but not economic occurrence is in impact structures resulting from the collision of major meteorites on the earth.

Compared to Australia and Congo, the major 2003 and 2004 producers of industrial diamond, Russia, was a major producer of diamonds for the study area and produced about 18 percent of world production in 2003 (table 32) (U.S. Geological Survey, 2004). The world reserve base of industrial diamond is estimated to be about 1,240 million carats. In 2003, the total industrial diamond production was estimated at 65.5 million carats (U.S. Geological Survey, 2004). In 2003 and 2004, production occurred from major mines in Australia, Botswana, Congo, Russia, and South Africa (U.S. Geological Survey, 2004, 2005).

Table 32. Diamond (industrial) - data for 2003 for world mine production, reserves, and reserve base for the study area and for the leading global producer (U.S. Geological Survey, 2005).

\begin{tabular}{l|l|l|l|l}
\hline Country & $\begin{array}{l}\text { Percent of world production, } \\
2003\end{array}$ & $\begin{array}{l}\text { Rank of world } \\
\text { production }\end{array}$ & $\begin{array}{l}\text { Percent of world } \\
\text { reserves }\end{array}$ & $\begin{array}{l}\text { Percent of world reserve } \\
\text { base }\end{array}$ \\
\hline Russia & 18.0 & 3 & 7.0 & 5.2 \\
Australia & 29.2 & 1 & 15.7 & 18.4
\end{tabular}

About eleven industrial diamond deposits occur in Greenland, Europe, Russia, and Northern Central Asia, all in Russia (table 2B, fig. 8D). The industrial diamond deposits, for which published data are available, are as follows: Ajkhal, Internacional'naja, Jubilejnaja, Mir-Sputnik, Ozjornaja, Sytykanskaja, Snezhinka, Udachnaja, Verkhotina, and Yubileinaya pipes in Russia. No production data are available.

Russia is the world's largest producers of gem quality diamonds (Interfax Mining and Metals, 2004) and accounts for 21 percent of global diamonds produced (MBendi World: Mining, 2004). Most of Russia's diamonds are located in three regions, the Arkhangelsk region, Perm 
region, and the Sakha/Yakutsk Republic. Russia's main diamond mining enterprise, Almazy RossiiSakha (Alrosa), which mines over 98 percent of the country's diamond output, that occurs in the Sakha/Yakutsk Republic, is planning to increase production at the Yubeleyniy open pit and by developing the Botuobinskaya pipe. Alrosa produces diamonds from seven hard-rock deposits (Udachny, Zarnitsa, Sytykan, Jubilee, Mir, Aikhal, and International pipes) and at three alluvial operations (Irelyakh River, Vodorazdelnye Galechniki, and Yraas-Yuryakh Creek). The large openpit mines at the Udachnaya and Jubilee kimberlite pipes in the Sakha Republic (formerly Yakutia) are in operation. All other open-pit mines are closed, but underground mining has started at the International, Ajkhal, and Zarnitsa pipes. New deposits are being developed at Nakyn and at the Lomonosov group in northwest Russia.

\section{Diatomite}

Diatomite is fine, powdered diatomaceous earth, a light-colored, porous rock composed of the shells of silica-rich diatoms, a marine microfossil that accumulates in mainly Cenozoic age marine or lacustrine (lake-deposited) sedimentary rock. Diatomite is used in filters, absorbents, fillers, and cement manufacture. Compared to the United States, the major 2003 and 2004 producer of diatomite, the Commonwealth of Independent States, Czech Republic, France, and Spain, the major producers for the study area, produced about 13.2 percent of world production in 2003 (table 33) (U.S. Geological Survey, 2004, 2005). The world reserves of diatomite is estimated to be about 920,000 thousand tonnes. The world's diatomite resources are estimated as large. In 2003 and 2004, production occurred from major mines in China, Commonwealth of Independent States, Czech Republic, France, Japan, Korea, Mexico, Peru, Spain, and the United States (U.S. Geological Survey, 2004, 2005).

Table 33. Diatomite - data for 2003 for world mine production, reserves, and reserve base for the study area and for the leading global producer (U.S. Geological Survey, 2004).

\begin{tabular}{l|l|l|l|l}
\hline Country & $\begin{array}{l}\text { Percent of world } \\
\text { production, 2003 }\end{array}$ & $\begin{array}{l}\text { Rank of world } \\
\text { production }\end{array}$ & Percent of world reserves & Percent of world reserve base \\
\hline $\begin{array}{l}\text { Commonwealth of } \\
\text { Independent States }\end{array}$ & 4.7 & 5 & Unknown & Minor \\
Czech Republic & 2.0 & & & Minor \\
France & 4.4 & $8($ tied $)$ & 0.5 & Very minor \\
Spain & 2.1 & 6 & Unknown & Unknown \\
United States & 18.9 & 7 & Unknown & Large
\end{tabular}

About six major diatomite deposits occur in the study area (table 2B, fig. 8D). The major diatomite deposits, for which published data are available, are as follows: Borovany deposit in Czech Republic; Riom-es-Montagnes deposit in France; Kisatibskoe deposit in Georgia; Lake Myvatn deposit in Iceland; and the Mociar deposit in Slovakia.

\section{Feldspar}

Feldspar is a group of abundant rock-forming minerals that occur in igneous and metamorphic rock and consists of silicon with aluminum, potassium, sodium, and calcium. About 60 percent of the earth's upper crust is composed of feldspar. Feldspar is used as a filler, to make glass and pottery. Compared to Italy, the major 2003 and 2004 producer of feldspar, the Czech Republic, France, Germany, Greece, Norway, Poland, Portugal, and Spain, the other major producers for the study area, produced about 22.8 percent of world production in 2003 (table 34) 
(U.S. Geological Survey, 2004, 2005). Quantitative estimates of reserves and reserve base are not available In 2003 and 2004, production occurred from major mines in Egypt, Greece, Germany, Iran, Italy, Korea, Mexico, Poland, Portugal, Spain, Thailand, Turkey, Venezuela, and the United States (U.S. Geological Survey, 2004, 2005).

Table 34. Feldspar - data for 2003 for world mine production, reserves, and reserve base for the study area and for the leading global producer (U.S. Geological Survey, 2004).

\begin{tabular}{l|l|l}
\hline Country & Percent of world production, 2003 & Rank of world production \\
\hline Czech Republic & 3.8 & 9 \\
France & 6.3 & 5 \\
Germany & 4.3 & 6 \\
Greece & 1.0 & 18 \\
Italy & 24.0 & 1 \\
Norway & 0.7 & 19 \\
Poland & 1.9 & 14 \\
Portugal & 0.5 & 17 \\
Spain & 4.3 & 6
\end{tabular}

About eight major feldspar deposits occur in the study area (table 2B, fig. 8D). The major feldspar deposits, for which published data are available, are as follows: Dolni Bory igneous deposit in the Czech Republic; Etang-sur-Arroux igneous deposit in France; HirschauSchnaittenbach sedimentary deposit in Germany; Brusnengo, Campiglia Marittima, igneous deposit in Italy; Salamonde igneous deposit in Portugal; Lupikko igneous deposit in Russia; and the Backegruvan igneous deposit in Sweden. No production or reserve data are available.

\section{Fluorspar}

Fluorspar is a calcium and fluorine compound formed as a byproduct of industrial processes. The naturally occurring mineral of the same composition is called fluorite that occurs mainly in silica-rich and altered granite, in polymetallic veins along with zinc and lead sulfide minerals (fig. 5), and phosphate-rich sedimentary rock and dolomite and limestone. Most fluorite deposits are hydrothermal deposits formed by replacement of carbonate rock, such as limestone, near masses of igneous source rock. Fluorspar is used as a flux in steelmaking, glass manufacture, and cement production. Most of the use of fluorspar is for the manufacture of hydrofluoric acid, which is a key ingredient in the manufacture of aluminum and uranium. Hydrofluoric acid also can be used to make water fluoridation chemicals that are added to municipal water supplies to help reduce tooth decay. Compared to China, the major 2003 and 2004 producer of fluorspar, France, Russia, and Spain, the major producers for the study area, produced about 8 percent of world production in 2003 (table 35) (U.S. Geological Survey, 2004, 2005). Quantitative estimates of reserves and reserve base are not available In 2003 and 2004, production occurred from major mines in Egypt, Greece, Germany, Iran, Italy, Korea, Mexico, Poland, Portugal, Spain, Thailand, Turkey, Venezuela, and the United States (U.S. Geological Survey, 2004, 2005). The world reserve base of fluorspar is estimated to be about 480,000 thousand tonnes. In 2003, the total fluorspar production was estimated at 4,750 thousand tonnes (U.S. Geological Survey, 2004). In 2003 and 2004, production occurred from major mines in China, France, Kenya, Mexico, Mongolia, Morocco, Namibia, Russia, South Africa, and Spain. 
Table 35. Fluorspar - data for 2003 for world mine production, reserves, and reserve base for the study area and for the leading global producer (U.S. Geological Survey, 2004).

\begin{tabular}{l|l|l|l|l}
\hline Country & $\begin{array}{l}\text { Percent of world production, } \\
2003\end{array}$ & $\begin{array}{l}\text { Rank of world } \\
\text { production }\end{array}$ & $\begin{array}{l}\text { Percent of world } \\
\text { reserves }\end{array}$ & $\begin{array}{l}\text { Percent of world reserve } \\
\text { base }\end{array}$ \\
\hline France & 2.0 & 7 & 4.2 & 3.0 \\
Russia & 3.7 & 8 & Unknown & 3.9 \\
Spain & 2.3 & 7 & 2.5 & 1.7 \\
China & 45.0 & 1 & 8.9 & 23.2
\end{tabular}

About nine major fluorite deposits occur in the study area (table $2 \mathrm{~B}$, fig. $8 \mathrm{~B}$ ). The major fluorite deposits, for which published data are available, are as follows: Albigeois District, Font Sante, and Morvan district hydrothermal deposits in France; Rottleberode hydrothermal deposit in Germany; Northern Italy district hydrothermal deposit in Italy; Taskainar, and South igneous deposit in Kazakhstan; Voznesenka-2 igneous deposit in Russia; and the Peninine igneous deposit in the United Kingdom. In Russia, the Voznesenka-2 igneous deposit has resources of 450 million tonnes fluorite ore averaging 30-35 percent $\mathrm{CaF}_{2}$. The deposit has been mined since 1960's, and is currently the largest producer of fluorite in Russia (Ariunbileg and others, 2003). No other production or reserve data are available.

\section{Gemstones}

The terms "gem" and "gemstone" mean any mineral or organic material (for example, pearl and petrified wood) used for personal adornment, display, or objects of art because it possesses beauty, durability, and rarity (Mineral Information Institute, USGS, and American Coal Foundation, undated). Examples of minerals that are used as gemstones include amethyst (purple variety of quartz), beryl, diamond, garnet, malachite, topaz, and tourmaline. Blue topaz is considered a gemstone even though the brilliant blue color usually is produced by irradiation and heating of drab topaz. Because gemstones within the region often are produced by small miners, it can be difficult to identify true production levels or quantify the size of reserves or potential resources. In Greenland, Europe, Russia, and Northern Central Asia, the principal gemstone under production is diamond (U.S. Geological Survey, 2004). Refer to the above section on Diamond (industrial) for additional information.

\section{Graphite}

Graphite is a gray to black, opaque, flexible but not elastic, soft crystalline form of carbon with a metallic luster. Graphite occurs mainly in metamorphosed sedimentary rock. Graphite is considered a semimetal because it exhibits chemical properties of both a metal and a nonmetal, which make it suitable for many industrial applications. The metallic properties include thermal and electrical conductivity. The nonmetallic properties include chemical inertness, lubrication qualities, and high thermal resistance. Graphite is used mainly in brake linings and in refractories, which are heat-resistant materials such as those used in the brick lining of furnaces and kilns. Graphite also is an important component in steel.

Compared to China, the major 2003 and 2004 producer of graphite, the Czech Republic, the major producer for the study area, produced about 1.9 percent of world production in 2003 (table 36) (U.S. Geological Survey, 2004, 2005). The world reserve base of graphite is estimated to be about 290,000 thousand tonnes of graphite. In 2003, the total graphite production was estimated at 780 thousand tonnes (U.S. Geological Survey, 2004). In 2003 and 2004 production occurred from 
major mines in Brazil, Canada, Czech Republic, India, Korea, Madagascar, Mexico, and the United States (U.S. Geological Survey, 2004, 2005).

Table 36. Graphite - data for 2003 for world mine production, reserves, and reserve base for the study area and for the leading global producer (U.S. Geological Survey, 2004).

\begin{tabular}{l|l|l|l|l}
\hline Country & $\begin{array}{l}\text { Percent of world production, } \\
2003\end{array}$ & $\begin{array}{l}\text { Rank of world } \\
\text { production }\end{array}$ & $\begin{array}{l}\text { Percent of world } \\
\text { reserves }\end{array}$ & $\begin{array}{l}\text { Percent of world reserve } \\
\text { base }\end{array}$ \\
\hline $\begin{array}{l}\text { Czech } \\
\text { Republic }\end{array}$ & 1.9 & 8 & 13.3 & 4.5 \\
China & 57.5 & 1 & 74.7 & 77.0
\end{tabular}

Economic graphite deposits are mainly metamorphic deposits in which graphite occurs in three forms that can have different applications. Flake graphite is composed of flat, plate-like grains disseminated in metamorphosed sedimentary rocks. Lump graphite is a high-crystalline form that occurs in veins. Amorphous graphite is a microcrystalline form of graphite that occurs in thermally metamorphosed sediments and coal.

About twelve graphite deposits occur in the study area (table 2A, fig. 7B). The graphite deposits, for which published data are available, are as follows: Doppl-Muehldorf-Zettlitz, Kaiserberg, and Trieben deposits in Austria; Cesky-Krumlov, Kolledeye, Mestsky-Vrch, Velke, and Vrbno-Konstantin deposits in Czech Republic; Kropfmuehl deposit in Germany; Pinerolo deposit in Italy; Baia de Fier deposit in Romania; Tayginsk deposit in Russia; and the Zavalyevskiy deposit in Ukraine. No production data are available.

\section{Gypsum}

The mineral gypsum is composed of calcium, sulfur, and oxygen in the form of hydrated calcium sulfate. Gypsum occurs mainly in sedimentary rock formed under evaporation (fig. 5) and is the most common of the approximately 150 sulfate minerals. Gypsum often occurs with halite (table salt) and sedimentary potash deposits. More than two-thirds of the gypsum mined is used for plaster and wallboard in houses and other buildings, and is used in agriculture for soil conditioning. Other uses are for smelting, glassmaking, and cement manufacture.

Compared to the United States, the major 2003 and 2004 producer of gypsum, Austria, France, Italy, Poland, Spain, and the United Kingdom, the major producers for the study area, produced about 15.6 percent of world production in 2003 (table 37) (U.S. Geological Survey, 2004, 2005). The world reserve base of gypsum is large. In 2003, the total gypsum production was estimated at 104,000 thousand tonnes (U.S. Geological Survey, 2004). In 2003 and 2004, production occurred from major mines in Australia, Austria, Brazil, Canada, China, Egypt, France, India, Iran, Italy, Japan, Mexico, Poland, Spain, Thailand, United Kingdom, Uruguay, and the United States (U.S. Geological Survey, 2004, 2005). 
Table 37. Gypsum - proportion data for 2003 for world mine production for the study area and for the leading global producer (U.S. Geological Survey, 2004).

\begin{tabular}{l|l|l}
\hline Country & Percent of world production, 2003 & Rank of world production \\
\hline Austria & 1.0 & 18 \\
France & 3.4 & 10 \\
Italy & 1.2 & 15 \\
Poland & 1.1 & 16 \\
Spain & 7.4 & 4 \\
United Kingdom & 1.5 & 14 \\
United States & 15.7 & 1
\end{tabular}

About seven gypsum deposits occur in the study area (table 2B, fig. 8B). The gypsum deposits, for which published data are available, are as follows: Koberice deposit in Czech Republic; Pouillon and Taverny deposits in France; Niedersachswerfen deposit in Germany; Lazinskoe and Novomoskovskoe deposits in Russia; and the Artemovskoe deposit in Ukraine. No production or reserve data are available.

Halite (salt)

Halite (salt) is necessary to support life. Salt occurs as the mineral halite (sodium and chlorine) that mainly forms in sedimentary deposits. Both halite and other salt minerals, such as sylvite (potassium and chlorite) often occur together with gypsum, and with potash and phosphate minerals in both modern and ancient evaporative sedimentary basins (fig. 5). The chemical industry produces about 40 percent of the world's salt, which is also a major source of chlorine. About 35 percent of salt produced is for highway deicing (Mineral Information Institute, USGS, and American Coal Foundation, undated). World resources of salt are practically unlimited, and the salt content of the oceans is virtually inexhaustible (U.S. Geological Survey, 2004). Data are not available on individual countries world production or world reserve base. Reserves and reserve base are large (U.S. Geological Survey, 2004). Economic and subeconomic deposits of salt are substantial in principal salt-producing countries.

Compared to the United States, the major 2003 and 2004 producer of halite, France, Germany, Italy, Poland, Russia, Spain, Ukraine, and the United Kingdom, the major producers for the study area, produced about 20.3 percent of world production in 2003 (table 38) (U.S.

Geological Survey, 2004). In 2003, the total salt production was estimated at 210,000 thousand tonnes (U.S. Geological Survey, 2004). In 2003 and 2004, salt production occurred from major mines in Australia, Brazil, Canada, China, France, Germany, India, Italy, Mexico, Poland, Russia, Spain, Ukraine, United Kingdom, and the United States (U.S. Geological Survey, 2004, 2005). 
Table 38. Halite (salt) - proportion data for 2003 for world mine production for the study area and for the leading global producer (U.S. Geological Survey, 2004).

\begin{tabular}{l|l|l}
\hline Country & Percent of world production, 2003 & Rank of world production \\
\hline France & 3.3 & 8 \\
Germany & 6.7 & 4 \\
Italy & 1.7 & 11 \\
Poland & 1.7 & 12 \\
Russia & 1.4 & 14 \\
Spain & 1.5 & 13 \\
Ukraine & 1.2 & 15 \\
United Kingdom & 2.8 & 10 \\
United States & 19.6 & 1
\end{tabular}

Halite crystallizes when sea water is trapped in shallow basins and evaporates (fig. 5). The shallow basins can be collapse features (rifts) that occur at, or near continental margins, or closed interior basins such as the Great Salt Lake in Utah. The evaporation process is greatly aided by a dry (arid) climate. Production of salt is accomplished by dissolving old, sedimentary layers of salt with hot water and evaporating the solution, or by trapping sea water in shallow ponds on tidal flats. Old salt beds, or layers, also can be mined and the salt that is produced is suitable for highway deicing. Salts are produced at some level by most countries in Greenland, Europe, Russia, and Northern Central Asia.

In Greenland, Europe, Russia, and Northern Central Asia, deposits of salt and associated potash, bromine, iodine, boron, and magnesium minerals occur in Cenozoic sedimentary evaporate basins of Kazakhstan, southern Russia, Turkmenistan, and Uzbekistan. Some salt and potash deposits occur as tabular beds in older subsurface Mesozoic and even Paleozoic sedimentary rocks. Many of these commodities are in the surface and near-surface in the present-day arid environments adjacent to the Caspian Sea and Aral Sea.

About 48 salt deposits occur in the study area (table 2B). The deposits are numerous and occur in Belarus, Bosnia-Herzegovina, France, Germany, Italy, Kazakhstan, Netherlands, Poland, Russia, Spain, Tajikistan, Turkmenistan, Ukraine, and the United Kingdom (U.S. Geological Survey, 2004). No production or reserve data are available.

\section{Kyanite}

Kyanite is a gray or greenish-blue mineral composed of aluminum and silicate that occurs mainly in metamorphosed, clay-rich sedimentary rock of all ages. Kyanite is used in steel making, and for the manufacture of chemicals, glass, and nonferrous metals. Compared to South Africa, the major 2003 and 2004 producer of kyanite, France, the major producer for the study area, produced about 15.9 percent of world production in 2003 (table 39) (U.S. Geological Survey, 2004, 2005). The world reserve base of kyanite is large. In 2003, the total kyanite production was estimated at 410 thousand tonnes (U.S. Geological Survey, 2004). In 2003 and 2004, production occurred from major mines in France, India, South Africa, Zimbabwe, and the United States (U.S. Geological Survey, 2004, 2005). 
Table 39. Kyanite - data for 2003 for world mine production, reserves, and reserve base for the study area and for the leading global producer (U.S. Geological Survey, 2004).

\begin{tabular}{l|l|l}
\hline Country & Percent of world production, 2003 & Rank of world production \\
\hline France & 15.9 & 3 \\
South Africa & 53.7 & 1
\end{tabular}

Several major kyanite deposits occur in France (Mineral Information Institute, 2004). Reserves and reserve base are large in the United States and South Africa.

\section{Limestone and other carbonate rocks}

Limestone is a dark gray to white, common sedimentary rocks that is formed mostly of calcite (calcium carbonate) and lesser dolomite (magnesium carbonate) that commonly contains marine fossils. Limestone forms mainly in passive continental margin seas (fig. 5). Limestone and other carbonate rocks have diverse uses from high-volume, low-value construction aggregate, to lower-volume, higher-value uses for the production of lime, food, paper and plastic manufacturing, metal-ore processing, and clean air, water, and sewage. These uses maintain society's infrastructure, public health, and industries. For many years, commodities such as limestone were considered to be common materials that are readily available from nearby deposits. However, a variety of factors are changing that situation, including increased standards for chemical and physical qualities, increasingly diverse uses, depletion of the best local resources, and the economies of large-scale production. Consequently, huge new quarries are being developed to supply distant markets.

Compared to China, the major 2003 and 2005 producer of lime and limestone, Austria, France, Germany, Italy, Poland, Russia, and the United Kingdom, the major producers for the study area, produced about 22.4 percent of world production in 2003 (table 40) (U.S. Geological Survey, 2004, 2005). The world reserve base of lime and limestone is large. In 2003, the total lime and limestone production was estimated at 120,000 thousand tonnes (U.S. Geological Survey, 2004). In 2003 and 2004, production occurred from major mines in Austria, Brazil, Canada, China, France, Germany, Iran, Mexico, Poland, Russia, South Africa, the United Kingdom, and the United States (U.S. Geological Survey, 2004, 2005).

Table 40. Lime and limestone - data for 2003 for world mine production, reserves, and reserve base for the study area and for the leading global producer (U.S. Geological Survey, 2004).

\begin{tabular}{l|l|l}
\hline Country & Percent of world production, 2003 & Rank of world production \\
\hline Austria & 1.7 & 11 (tied with several other countries) \\
France & 2.1 & 9 \\
Germany & 5.8 & 5 \\
Italy & 2.6 & 7 \\
Poland & 1.7 & 11 (tied with several other countries) \\
Russia & 6.8 & 3 \\
United Kingdom & 1.7 & 11 (tied with several other countries) \\
China & 20.1 & 1
\end{tabular}

Reserves and reserve base are adequate for all listed countries. Limestone has been or is being produced from the study area in mines in Belarus, Denmark, Finland, France, Hungary, Ireland, Italy, Latvia, Malta, Poland, Russia, Ukraine, and the United Kingdom (table 1). The major limestone mines in the study area are at the Santa Augusta deposit in France, the Eger deposit in 
Hungary, the Gotland deposit in Sweden, the Komsomolskoe deposit in Ukraine, the Muschelkalk (Sachen-Anhalt) deposit in Germany, the Kletno III deposit in Poland, and the Dene Quarry deposit in the United Kingdom (table 2B, fig. 8A). No production or reserve data are available.

\section{Lithium}

Lithium is a soft, silvery, highly reactive metallic element that is widely distributed in the Earth's crust at low concentrations. The use of lithium compounds in ceramics, glass, and primary aluminum production represents more than 60 percent of estimated consumption (Mineral Information Institute, USGS, and American Coal Foundation, undated). Other major end uses for lithium are in heat transfer, in thermonuclear weapons, various alloys, ceramics, optical glass, and in the manufacture of lubricants and greases, pharmaceuticals, batteries, and synthetic rubber. Compared to Chile, the major 2003 and 2004 producer of lithium, Portugal, the major producer for the study area, produced about only 1.4 percent of world production in 2003 (table 41) (U.S. Geological Survey, 2004, 2005). The world reserve base of lithium is 11,000,000 tonnes. In 2004, the total lithium production was estimated at 14,200 tonnes (U.S. Geological Survey, 2005). In 2003 and 2004, production occurred from major mines in Argentina, Australia, Bolivia, Canada, Chile, China, Portugal, and Zimbabwe (U.S. Geological Survey, 2004, 2005).

Table 41. Lithium - data for 2003 for world mine production, reserves, and reserve base for the study area and for the leading global producer (U.S. Geological Survey, 2004).

\begin{tabular}{l|l|l|l|l}
\hline Country & $\begin{array}{l}\text { Percent of world production, } \\
2003\end{array}$ & $\begin{array}{l}\text { Rank of world } \\
\text { production }\end{array}$ & $\begin{array}{l}\text { Percent of world } \\
\text { reserves }\end{array}$ & $\begin{array}{l}\text { Percent of world reserve } \\
\text { base }\end{array}$ \\
\hline Portugal & 1.4 & 8 & Unknown & Unknown \\
Chile & 41.5 & 1 & 72.6 & 26.2
\end{tabular}

Lithium is concentrated in nature dominantly by igneous and sedimentary processes. During crystallization of silica-rich igneous (granitic) magma (fig. 5), elements such as lithium are concentrated late-stage fluid. The rock that crystallizes from this residual fluid-rich magma contains large, exotic minerals and is called a pegmatite. However, most lithium is currently produced from lithium-rich brines in sedimentary basins. These brines generally form by weathering of certain volcanic rocks concentration of the solution in desert basins with extreme evaporation.

Four lithium deposits are known in the study area (table 2A, fig. 7E). The lithium deposits, for which published data are available, are as follows: Belogorskoe pegmatite deposit in Kazakhstan; Guarda hydrothermal deposit in Portugal; and Belogorskoe and Tastygskoye igneous (pegmatite) deposits in Russia. The latter deposit contains estimated reserves of 450,000 tonnes lithium and consists of a pegmatite veins field that is more than $1000 \mathrm{~m}$ long and varies from $180 \mathrm{~m}$ thick in the northern part to $375 \mathrm{~m}$ in the southern part. No production or reserve data are available for the other deposits.

\section{Magnesium}

Magnesium is a silver-white, moderately hard metal that in ribbon or power form burns with a brilliant white flame. Magnesium occurs mostly as the mineral magnesite (magnesium carbonate) that in metamorphic rock, dolomite (iron-magnesium carbonate) in sedimentary rocks, and brucite (magnesium hydroxide) as an alternation of magnesium- and iron-rich (mafic) igneous rock. Magnesium is also produced from seawater and brines in sedimentary basins. Magnesite mostly is used by the refractories industry to make high-temperature bricks for furnaces, for 
industrial chemicals, for agricultural, chemical, pyrotechnic, for metal alloys, weapons, and environmental applications, and as a source of metallic magnesium used for making aluminum alloys.

Compared to China, the major 2003 and 2004 producer of magnestie, Austria, Greece, Russia, Slovakia, and Spain, the major producers for the study area, produced about 27.8 percent of world production in 2003 (table 42) (U.S. Geological Survey, 2004, 2005). The world reserve base of magnesite is 3,600,000 thousand tonnes. In 2003, the total magnesite production was estimated at 3,360 thousand tonnes (U.S. Geological Survey, 2004). In 2003 and 2004, production occurred from major mines in Australia, Austria, Brazil, China, Greece, India, Korea, Russia, Slovakia, Spain, and Turkey (U.S. Geological Survey, 2004, 2005). Identified world resources of magnesite total 12 billion tonnes, and of brucite, several million tonnes (U.S. Geological Survey, 2005). Resources of dolomite and magnesium-bearing evaporite minerals are enormous, and magnesiabearing brines are estimated to constitute a resource of billions of tonnes.

Table 42. Magnesite - data for 2003 for world mine production, reserves, and reserve base for the study area and for the leading global producer (U.S. Geological Survey, 2004).

\begin{tabular}{l|l|l|l|l}
\hline Country & $\begin{array}{l}\text { Percent of world production, } \\
2003\end{array}$ & $\begin{array}{l}\text { Rank of world } \\
\text { production }\end{array}$ & $\begin{array}{l}\text { Percent of world } \\
\text { reserves }\end{array}$ & $\begin{array}{l}\text { Percent of world reserve } \\
\text { base }\end{array}$ \\
\hline Austria & 6.0 & 5 & 0.8 & 0.7 \\
Greece & 4.2 & 8 & 1.6 & 1.1 \\
Russia & 8.9 & 3 & 35.7 & 26.7 \\
Slovakia & 4.2 & 9 & 2.3 & 11.7 \\
Spain & 4.5 & 6 & 0.5 & 1.1 \\
China & 32.7 & 1 & 20.9 & 31.5
\end{tabular}

About twelve magnesium deposits occur in the study area (table 2A, B; fig. 7C, 8B). The magnesium deposits, for which published data are available, are as follows: Breitenau, Hochfilzen and Radenthein, hydrothermal deposits in Austria; Yerikini hydrothermal deposit in Greece; Savinskoe hydrothermal deposit in Russia; Ddbrava-Miková, Lubenik, Ochtiná, Ratkovská Suchá, and Sirk hydrothermal deposits and Kosice sedimentary deposit in Slovakia. The Savinskoe hydrothermal deposit in Russia contains reserves of about 300 million tonnes of ore and consists of a talc and magnesite replacement of a metamorphosed sedimentary rock rich in dolomite. No production data are available for the other deposits.

\section{Perlite}

Perlite is a natural volcanic glass that is similar to obsidian, but has distinctive concentric cracks and relatively high water content. Perlite forms from the surface eruption and rapid cooling of crystal-poor and water rich magma erupted onto continental margin arcs and back arc areas (fig. 5). Perlite is used mostly in the construction industry, in gardening as horticultural aggregate, and in water filters.

Compared to the United States, the major 2003 and 2004 producer of perliteGreece and Hungary, the major Eurasian producers for the study area, produced about 33.4 percent of world production in 2003 (table 43) (U.S. Geological Survey, 2004, 2005). The world reserve base of perlite is 7,700,000 thousand tonnes. In 2003, the total perlite production was estimated at 1,600 thousand tonnes (U.S. Geological Survey, 2004). In 2003 and 2004, production occurred from major mines in Armenia, Greece, Hungary, Japan, Turkey, and the United States (U.S. Geological Survey, 2004, 2005). 
Table 43. Perlite - data for 2003 for world mine production, reserves, and reserve base for the study area and for the leading global producer (U.S. Geological Survey, 2004).

\begin{tabular}{l|l|l|l|l}
\hline Country & $\begin{array}{l}\text { Percent of world production, } \\
2003\end{array}$ & $\begin{array}{l}\text { Rank of world } \\
\text { production }\end{array}$ & $\begin{array}{l}\text { Percent of world } \\
\text { reserves }\end{array}$ & $\begin{array}{l}\text { Percent of world reserve } \\
\text { base }\end{array}$ \\
\hline Greece & 22.5 & 2 & 7.1 & 3.0 \\
Hungary & 10.9 & 3 & 0.4 & NA \\
United & 32.0 & 1 & 7.1 & 2.6 \\
States & & & &
\end{tabular}

Four perlite deposits are known in the study area (table 2B, fig. 8C). The perlite deposits, for which published data are available, are as follows: Agean deposits in Greece; Palhaza deposit in Hungary; Morgongiori deposit in Italy; Gradesnica deposit in Macedonia; and the Lehotka pod Brehy deposit in Slovakia. No production or reserve data are available.

\section{Phosphate}

Phosphate is a mineral compound containing phosphorous and oxygen. Phosphate is an essential element for plant and animal nutrition and is indispensable for world food production. Phosphate is mined from phosphorus-enriched rock, including both sedimentary and igneous rocks (fig. 5). Phosphate is used in phosphoric acid and in compounds for industrial and food-additives, and for fertilizers.

Compared to the United States, the major 2003 and 2004 producer of phosphate, Russia, the major producer for the study area, produced about 33.4 percent of world production in 2003 (table 44) (U.S. Geological Survey, 2004, 2005). The world reserve base of phosphate is 50,000,000 thousand tonnes. In 2003, the total phosphate production was estimated at 137,000 thousand tonnes (U.S. Geological Survey, 2005). In 2003 and 2004, production occurred from major mines in Australia, Brazil, Canada, China, Egypt, India, Israel, Jordan, Morocco, Russia, Senegal, South Africa, Syria, Togo, Tunisia, and the United States (U.S. Geological Survey, 2004, 2005).

Table 44. Phosphate rock - data for 2003 for world mine production, reserves, and reserve base for the study area and for the leading global producer (U.S. Geological Survey, 2004).

\begin{tabular}{l|l|l|l|l}
\hline Country & $\begin{array}{l}\text { Percent of world production, } \\
2003\end{array}$ & $\begin{array}{l}\text { Rank of world } \\
\text { production }\end{array}$ & $\begin{array}{l}\text { Percent of world } \\
\text { reserves }\end{array}$ & $\begin{array}{l}\text { Percent of world } \\
\text { reserve base }\end{array}$ \\
\hline Russia & 8.0 & 4 & 1.1 & 2.0 \\
United & 24.2 & 1 & 5.6 & 8.0
\end{tabular}

About 80 percent of the world's phosphate production comes from sedimentary deposits of phosphate rock that form on or near the margins of continents where organic productivity is high and there is a limited influx, and dilution by, other sediments (Harben and Kužvart, 1996; Harben, 2002). High marine biological productivity often is associated with upwelling currents along continental margins. These currents bring phosphorus-rich cold waters from deeper ocean levels nearer the surface. This nourishes and stimulates growth of plants and animals whose remains accumulate on the sea bottom as concentrations of phosphorus-rich organic debris. This phosphaterich debris forms extensive layers that cover thousands of square kilometers and eventually may become phosphate-rock deposits.

Phosphate also is derived from the igneous mineral apatite during the intense weathering of sodium- and potassium-rich (alkaline) igneous rock (Mariano, 1989). Apatite is composed principally of calcium, phosphorous, carbon, and oxygen, and usually is present in only tiny 
amounts in most igneous rocks. Intense weathering of these rocks form soils (laterites) sufficiently enriched in phosphate (see also columbium-niobium and titanium) to be mined.

About 25 major phosphate deposits occur in the study area (table 2A, B; fig. 8C). The phosphate deposits, for which published data are available for deposits that phosphate is the primary commodity, are as follows: Krichev sedimentary deposit in Belarus; Siilinjrvi sedimentary and Sokli igneous deposits in Finland; Aksaj, Aktyubinsk, Chilisai, Chulaktau-I, Janytas, Karanynsaj-Temborgen, Karatau Basin, Koksu, Melovoe, Pokrovskoe, and Zhanatas sedimentary deposit in Kazakhstan; Khibiny Complex, Kovdor, Sebl'yavr, and Seligdarskoe igneous deposits, and Telek, and Viatka Kama sedimentary deposits in Russia; Aldea Moret igneous deposit in Spain; Kiruna igneous deposit in Sweden; Dzheroj-Syrdara and Dzheroj-Tashkura sedimentary deposits in Uzbekistan. The latter deposit has produced 129 million tonnes of ore (Levine, 1998). The Aktyubinsk sedimentary deposit in Kazakhstan has substantial phosphate resources; and the Karatau Basin sedimentary deposit in Kazakhstan has substantial phosphate resources (Kirkham and Rafer, 2003).

\section{Potash (Potassium)}

The term potash refers to a group of water-soluble salts that contain the chemical element potassium, and includes the mineral potassium chlorite (sylvite), and various other potassium sulfate, potassium-magnesium sulfate, and potassium nitrate minerals. Like phosphorous, potassium is an essential element for animal and plant nutrition and food production and is present in every living cell. Over 95 percent of potash production is used for fertilizers; the other major use is for the chemical industry.

Compared to the Canada, the major 2003 and 2004 producer of potash, Belarus, Germany, Russia, Spain, and Ukraine, the producers for the study area, produced about 46.2 percent of world production in 2003 (table 45) (U.S. Geological Survey, 2004, 2005). The world reserve base of potash is 17,000,000 tonnes of $\mathrm{K}_{2} \mathrm{O}$ concentrate. In 2004, the total potash production was estimated at 30,400 tonnes (U.S. Geological Survey, 2005). In 2003and 2004, production occurred from major mines in Belarus, Brazil, Canada, Chile, Germany, Israel, Jordan, Russia, Spain, Ukraine, the United Kingdom, and the United States (U.S. Geological Survey, 2004, 2005).

Table 45. Potassium - data for 2003 for world mine production, reserves, and reserve base for the study area and for the leading global producer (U.S. Geological Survey, 2004).

\begin{tabular}{l|l|l|l|l}
\hline Country & $\begin{array}{l}\text { Percent of world production, } \\
2003\end{array}$ & $\begin{array}{l}\text { Rank of world } \\
\text { production }\end{array}$ & $\begin{array}{l}\text { Percent of world } \\
\text { reserves }\end{array}$ & $\begin{array}{l}\text { Percent of world reserve } \\
\text { base }\end{array}$ \\
\hline Belarus & 14.6 & 3 & 9.1 & 6.0 \\
Germany & 13.1 & 4 & 8.6 & 5.1 \\
Russia & 16.8 & 2 & 21.8 & 13.3 \\
Spain & 1.7 & 9 & 0.2 & 0.2 \\
Ukraine & 0.03 & 13 & 0.3 & 0.2 \\
Canada & 31.0 & 1 & 53.2 & 58.6
\end{tabular}

The geologic source for about a large part of the world's potash production is a sedimentary rock layer or evaporate deposit that formed where a part of the sea was isolated in a basin and evaporated forming layers of minerals from the components that were dissolved in the sea water (fig. 29). Potash is also produced from brine deposits that also form by the evaporation of salt water, either sea water or water that has had chemical components dissolved from adjacent rocks and washed into a basin. Brine deposits tend to form in arid climates, are relatively inexpensive to 
mine, and often have the potential for co-production of other commodities. Potash occurs with halite and other evaporative minerals in brine deposits.

About 11 potash deposits occur in the study area (table 2B, fig. 8C). The potash deposits, for which published data are available for deposits that potash is the primary commodity, are as follows: Starobinsk sedimentary deposit in Belarus; Mulhouse Basin sedimentary deposit in France; Niedersachsen-Riedal and Salzdetfurth sedimentary deposits in Germany; Klodawa sedimentary deposit in Poland; Verkhnekamsk sedimentary deposit in Russia; Suria sedimentary deposit in Spain; Gaurdak sedimentary deposit in Turkmenistan; Petrikovskoe and Stebnikovskoe sedimentary deposits in Ukraine; and the Boulby sedimentary deposit in the United Kingdom. No production or reserve data are available.

\section{Pumice}

Pumice is a volcanic rock that is light and full of cavities. It is a glassy rock that forms from very rapid cooling of crystal-poor igneous magma erupted onto continental margin arcs and in back arc areas (fig. 5). Pumice is used primarily in building blocks, cement, in abrasives, concrete, horticulture, landscaping, and laundries.

Compared to the Italy, the major 2003 and 2004 producer of pumice, France, Germany, and Greece, the other major producers for the study area, produced about 24.2 percent of world production in 2003 (table 46) (U.S. Geological Survey, 2004, 2005). The world reserve base of pumice is very large because pumice is greatly abundant in volcanic arcs around the world. In 2003, the total pumice production was estimated at 13,000 thousand tonnes (U.S. Geological Survey, 2004). In 2003 and 2004, production occurred from major mines in Algeria, Chile, Ecuador, France, Germany, Greece, Guadeloupe, Guatemala, Iran, Italy, Spain, Turkey, and the United States (U.S. Geological Survey, 2004, 2005).

Table 46. Pumice - data for 2003 for world mine production, reserves, and reserve base for the study area and for the leading global producer (U.S. Geological Survey, 2004).

\begin{tabular}{l|l|l}
\hline Country & $\begin{array}{l}\text { Percent of world } \\
\text { production, 2003 }\end{array}$ & Rank of world production \\
\hline France & 3.5 & 8 \\
Germany & 3.8 & 7 \\
Greece & 12.3 & 3 \\
Italy & 35.4 & 1 \\
Spain & 4.6 & 6
\end{tabular}

Data on three major pumice deposits are available for the study area (table $2 \mathrm{~B}$, fig. $8 \mathrm{C}$ ). The pumice deposits, for which published data are available, are as follows: Yali deposit in Greece; and the Acquacalda and Porticello deposits in Italy. No production or reserve data are available.

\section{Silicon}

Silicon is a nonmetallic element that occurs extensively in the earth's crust in silicate minerals, including quartz (silicon and oxygen), an extremely common crustal mineral. Quartz and other silicate minerals are used for concrete, brick, industry, pottery, various refractories including iron and steel industries, and aluminum and aluminum alloys, and in the chemical industry. Silicon metal is used extensively for transistors and other semiconducting devices.

Compared to China, the major 2003 and 2004 producer of silicon, France, Iceland, Kazakhstan, Norway, Poland, Russia, Slovakia, Spain, and Ukraine, the major Eurasian producers 
for the study area, produced about 36.1 percent of world production in 2003 (table 47) (U.S. Geological Survey, 2004, 2005). The world reserve base of silicon is very large because silicon is greatly abundant in igneous arcs and in sedimentary rocks formed of debris eroded from igneous rocks from around the world. In 2003, the total silicon production was estimated at 4,390 thousand tonnes (U.S. Geological Survey, 2004). In 2003 and 2004, production occurred from major mines in Brazil, Canada, China, France, Iceland, India, Kazakhstan, Norway, Poland, Russia, Slovakia, South Africa, Spain, Ukraine, and Venezuela (U.S. Geological Survey, 2004, 2005).

Table 47. Silicon - data for 2003 for world mine production, reserves, and reserve base for the study area and for the leading global producer (U.S. Geological Survey, 2004).

\begin{tabular}{l|l|l}
\hline Country & Percent of world production, 2003 & Rank of world production \\
\hline France & 2.5 & 9 \\
Iceland & 1.8 & 11 \\
Kazakhstan & 2.1 & 10 \\
Norway & 8.8 & 3 \\
Poland & 0.8 & 15 (tied) \\
Russia & 12.0 & 2 \\
Slovakia & 0.8 & 15 (tied) \\
Spain & 1.5 & 13 \\
Ukraine & 5.8 & 5 \\
China & 40 & 1
\end{tabular}

No data on major silicon deposits are available for the study area in readily accessible publications (table 2B). This absence of data is probably the result of silicon being very abundant in quartz and other common crustal minerals around the world.

\section{Strontium}

Strontium is a metallic element that commonly occurs in nature; however, only two minerals, celestite (strontium, sulfur, and oxygen) and strontianite (strontium, carbon, and oxygen) contain strontium in sufficient quantities to make recovery practical. Celestite is processed into a variety of strontium chemicals that are used mainly in the faceplate glass of color television picture tubes and to a lesser degree for specialty magnets and pyrotechnics.

Spain, the major global producer of strontium in 2003 and 2004, produced about 35.3 percent of world production in 2003 (table 48) (U.S. Geological Survey, 2004, 2005). The world reserve base of strontium is $12,000,000$ tonnes. In 2003, the total strontium production was estimated at 470,000 tonnes (U.S. Geological Survey, 2005). In 2003 and 2004, production occurred from major mines in Argentia, China, Iran, Mexico, Morocco, Pakistan, Spain, Tajikstan, and Turkey.

Table 48. Strontium - data for 2003 for world mine production for the study area and for the leading global producer (U.S. Geological Survey, 2004).

\begin{tabular}{l|l|l}
\hline Country & Percent of world production, 2003 & Rank of world production \\
\hline Spain & 35.3 & 1
\end{tabular}

Most celestite deposits form as sedimentary deposits in lakes and coastal lagoons, also form in evaporate deposits where it is one of the last minerals to be formed as the salty water (brine) 
evaporates (fig. 5). Associated with celestite are strontianite and barite. The only European producer and also the leading strontium global producer is Spain.

About six strontium deposits occur in the study area (table 2A, fig. 7D). The strontium deposits, for which published data are available for deposits that strontium is the primary commodity, are as follows: Aurtash sedimentary deposit in Kazakhstan; the very large sedimentary Montevive deposit in Spain; Arikskoe, Central Karakumskoe, and Karashor sedimentary deposits in Turkmenistan; and the Sherabad sedimentary deposit in Sherabad. No production or reserve data are available.

\section{Sulfur}

Sulfur is a pale yellow nonmetallic element that occurs widely in nature as both an element and in various sulfide minerals. Most sulfur is obtained as a byproduct from oil and gas production. Other principal sources of sulfur are sedimentary evaporate deposits, hydrothermal sulfide ore deposits, and native sulfur from volcanoes. Sulfur is used in black gunpowder, rubber manufacture, fertilizers, petroleum refining, metal mining, manufacture of insecticides and pharmaceuticals, and in the preparation of compounds such as hydrogen sulfide and sulfuric acid. Most sulfur is used to manufacture sulfuric acid, which is used to produce agricultural chemicals and for a variety of industrial applications.

Compared to the United States, the major 2003 and 2004producer of sulfur, Finland, France, Germany, Italy, Kazakhstan, Netherlands, Poland, Russia, and Spain, the major producers for the study area, produced about 24.6 percent of world production in 2003 (table 49) (U.S. Geological Survey, 2004, 2005). The world reserve base of sulfur is very large because of the abundant occurrence of sulfur in crude oil, natural gas, and sulfide ores. In 2004, the total sulfur production was estimated at 63,000 thousand tonnes (U.S. Geological Survey, 2005). In 2003 and 2004, production occurred from major mines in Australia, Canada, Chile, China, Finland, France, Germany, India, Iran, Italy, Japan, Kazakhstan, Korea, Kuwait, Mexico, Netherlands, Poland, Russia, Saudi Arabia, Spain, United Arab Emirates, and the United States (U.S. Geological Survey, 2004, 2005). Because petroleum and sulfide ores can be process long distances from where they are produced, actual sulfur production may not be in the country for which the reserves are attributed. 
Table 49. Sulfur - data for 2003 for world mine production for the study area and for the leading global producer (U.S. Geological Survey, 2004).

\begin{tabular}{l|l|l}
\hline Country & Percent of world production, 2003 & Rank of world production \\
\hline Finland & 1.2 & $18($ tied) \\
France & 1.7 & 15 \\
Germany & 2.1 & 12 \\
Italy & 1.2 & $18($ tied $)$ \\
Kazakhstan & 3.7 & $7($ tied $)$ \\
Netherlands & 0.8 & 21 \\
Poland & 1.7 & $18($ tied) \\
Russia & 11.0 & 3 \\
Spain & 1.2 & $18($ tied) \\
United States & 16.2 & 1
\end{tabular}

\section{Summaries of Recent Regional Mineral Exploration and Major Active Mines}

\section{Introduction}

Worldwide expenditures for nonfuel mineral exploration have increased significantly in 2003 following 5 years of decline (Wilburn, 2004). The increase results from changing exchange rates, rising commodity prices, low metal inventories, and an improving global economy (Wilburn, 2004). Gold continued to lead exploration activity in 2003, with a budget increase of about 33 percent; nickel increased 29 percent, and platinum-group elements increased 26 percent (Wilburn, 2004). In recent years, the top three geographic areas for mineral exploration, based on exploration budgets, currently are Latin America, Canada, and Africa (fig. 1 in Wilburn, 2004). Exploration budgets, primarily for precious and base metals, for private companies conducting mineral exploration in the study area was minor in 2003, constituting less than 11 percent of the world total.

The following summaries of recent regional mineral exploration and major active mines are important data sets for understanding the current trends in the search for new deposits, and for understanding the economic importance that is derived from continued operation of major mines. This information, when linked to geologic setting of major mines and mineral deposit models, is important for discussions of geologic units or structures that may be favorable for new (undiscovered) deposits. The following summaries of mineral exploration and active mines are derived from the cited references. Please note that some major countries in the study area do not release this type of data.

\section{Factors Affecting Mineral Exploration}

Five main factors appear to affect mineral exploration: (1) high and low risk types of mineral exploration; (2) events such as demand and supply that cause changes in commodity prices; (3) collection of new geoscience information; (4) new technology; and (5) government policy. These factors often result in cycles of mineral exploration.

Mineral exploration activity can be divided into low risk and high risk types. Low risk exploration focuses on finding extensions to existing deposits, or new ore bodies, within a known trend or cluster of major deposits. This type of exploration activity often is driven by the depletion of reserves in known deposits. High risk exploration looks for ore deposits where none have been 
discovered previously. Many discoveries are made as the result of exploration programs based on geologic models that are both descriptive and predictive.

Mineral exploration is cyclical over time. Measures used to assess trends in minerals exploration activities include the number of active exploration properties, land acquisitions, expenditures, and number of discoveries. When plotted by year for a given area, these types of information reveal cyclic patterns superimposed on a base level of activity. Some of these cycles appear to be global, others regional.

Cycles of exploration are event-driven. These events include demand and supply that result in fluctuations in commodity price, new information, new technology, consolidation of the mining industry, changes in the investment climate, and changes in public policy. For example, between 1997 and 2000, the price of palladium increased from less than $\$ 200$ per ounce to over $\$ 1,000$ per ounce (Johnson, 2004). This resulted in a surge of exploration activity in areas where deposits of platinum-group elements can be found. Although palladium prices have dropped, platinum prices recently increased and will sustain interest in exploration for the platinum-group metals. As these new deposits are developed and studied, new deposit models will be developed that will guide future exploration programs elsewhere.

Systematic collection of many kinds of new geoscience information, both within and outside of areas of known potential for occurrence of undiscovered mineral deposits, can stimulate mineral exploration and new discoveries. Work supported by government, industry, and universities continually is generating and refining the scientific infrastructure and technological base needed by the mining industry to find new deposits. For instance, the recognition of favorable geologic environments and geochemical anomalies, combined with revisiting old prospects has led to new discoveries (Sillitoe, 1998).

Technological innovations in exploration methods, information analysis and visualization, mining, and mineral processing also can stimulate exploration activity. Examples of more recent techniques that have led to new discoveries are: (1) new geophysical techniques that indicate the direction and distance to electrically conductive bodies below the Earth's surface; (2) development of advanced remote sensing technology in satellites and aircraft; and (3) chemical heap-leaching techniques that permit the processing of low-grade bulk-tonnage ores.

Finally, government policies and programs can have a significant impact on minerals exploration. As previously discussed, governments can efficiently support exploration by creating scientific information available to all. However, laws on mineral rights, ownership, taxation, and environmental protection have an even stronger effect on stimulating or discouraging mineral exploration. For instance, funding of mineral exploration in Russia is expanding due to the country's continued strong economic growth and resultant foreign-based joint ventures (Wilburn, 2004). Other instances are: (1) the Ireland government initiative to gather and disseminate minerals exploration; (2) a master plan by the Japan International Cooperation Agency to develop the mining sector of Georgia; (3) the government of Armenia enacted a new prospecting and mining law; and (4) governmental subdizing of mineral exploration, development, and mining.

In recent years, much of the high-profile exploration in the study area has centered on precious and base metals (Wilburn, 2004). Exploration budgets for 2003 increased by 24 percent in recent years for Europe, Russia, and Northern Central Asia and account for about 11 percent of the world share. Exploration in Europe and Russia accounted for 56 percent of this total. Gold accounted for 42 percent of the 2003 exploration in this region; base metals for 28 percent, diamond exploration for 18 percent, and other minerals for 12 percent. Exploration was focused in 2003, in descending order of number of sites, in China, Turkey, Mongolia, Sweden, Romania, Russia, and India (Wilburn, 2004). In Europe, extensive gold exploration has occurred in Spain, Bulgaria, Russia, and Romania, and base metal exploration has focused on Sweden. Many prior 
areas of Europe are being re-evaluated with newer geophysical methods, and areas rich in base metals are being re-evaluated for PGE (platinum group elements). Russia's 2003 exploration was focused mainly on gold and PGE.

\section{Data on Recent Mining}

The following summaries of important data on major active mines provides for understanding the current trends in the search for new deposits, and for understanding the economic importance that is derived from continued operation of major mines. This information, when linked to geologic setting of major mines and mineral deposit models, is important for discussions of geologic units or structures that may be favorable for new (undiscovered) deposits. The following summaries of (relatively) recent mining (production) (table 1) in the study area are based primarily on the published reports of Levine and Wallace (2001), Steblez (2001, 2002), Steblez and others (2001), Kuo (2002a-d; 2003a, b), and Newman (2001a, b; 2002a-h; 2003a. b). Many of the active mines mentioned in the following summaries are not in mineral deposit database in table 2 because of a lack of publicly-available information on location, major commodities, deposit type, and geologic age.

\section{Mineral Exploration and Recent Mining in Greenland}

As of 2002, the Geological Survey of Denmark and Greenland was spending about $\$ 4.8$ million annually on geologic mapping (Kuo, 2002a). A hyperspectral geophysical survey was among the planned activities for 2002. Extensive geologic investigations of the Nalunaq gold, that is located $40 \mathrm{~km}$ from Nanortalik in southern Greenland, a bankable feasibility study, and an environmental impact assessment were completed in 2002. The mine was expected to start in 2003. An environmental baseline study was completed on natural resource use in the Nanortalik area by fishing, hunting, sheep farming, and tourism. Conflicts of interest could arise in the vicinity of the mine site and in surrounding areas. Crew Development Corporation of Canada announced an independent resource estimate for the Nalunaq gold project in southern Greenland based on the results of surface and underground fieldwork to the end of 2001. A feasibility study was to be completed in the second quarter of 2002 with a subsequent environmental impact assessment to be completed.

Despite geographic isolation, extensive ice fields, and lack of infrastructure, 30 mineral exploration licenses were in force in Greenland as of September, 2004 (Geological Survey of Denmark and Greenland, 2004). In addition, Greenland's first gold mine, Nalunaq Gold Mine, officially opened August 26, 2004. Since the systematic minerals exploration of Greenland started in the 1800's, moderate-size to major deposits of chromium, copper, crylolite, gold, iron, lead, molybdenum, phosphorous, PGE, rare-earth metals, yttrium, silver, and zinc have been discovered and mined (table 2, figs. 7- 8). Exploration efforts in 2004 emphasized diamonds and gold; however, some exploration continues for nickel, platinum-group elements, niobium-tantalum, colored gemstones, and some industrial minerals. Gold exploration is focusing on quartz carbonate gold veins spatially clustered near large faults zones in greenstone belts known to occur in several areas, particularly south Greenland. Exploration for kimberlite pipes, with potential for diamonds, is occurring in west-central Greenland, and approximately 600 diamonds have been recovered in two areas. An active exploration project is occurring on Ammassalak Island in East Greenland focused on nickel and PGE in ultramafic (magnesium- and iron-rich) rock of that may be related to komatiite. Exploration for nickel, copper, gold, and PGE continues at the Skaergaard intrusion and in the Hammar Dal area in West Greenland. A large, homogeneous resource of industrial olivine is also being investigated at the Seqi deposit in West Greenland. 
Active mining is occurring at the Nalunaq gold deposit in Greenland (Kuo, 2003b). Mining occurred in the past century at the Ivittuut crylolite deposit, the Mestersvig lead-zinc deposit, and the Maarmorilik lead-zinc-silver deposit (MINEX Online, http://www.geus.dk/minex/mx_historyuk.htm), and at the Amitsoq graphite mine, the Innatsiaq, and Josva, and Lillian copper deposits (ExploreNorth, http://www.explorenorth.com/ library/weekly/aa112400a.htm).

\section{Mineral Exploration and Recent Mining in Europe}

In recent years, exploration in Europe has been most active in Bulgaria, Finland, Ireland, Norway, Portugal, Romania, Italy (Sardinia), Slovakia, Spain, Sweden, and the United Kingdom (Scotland). Some of the exploration targets are for commodities that were never produced in some of these countries (Wilburn, 2004). For instance, diamonds in Finland and PGE (platinum group elements) in Scotland. Base-metal exploration is concentrated in Ireland and Sweden, and exploration for gold continued in Bulgaria, Greenland, Romania, and Spain. Other targets are in known deposits and districts such as the Suurikuusikko gold deposit in Finland, the Rosia Montana gold-silver deposit in the Apuseni district in Romania, and the Garpenberg and the Storliden zinc deposits in Sweden. The following description of mineral exploration in Europe is adapted mainly from Steblez (2001), Kuo (2002a-d; 2003a, b), and Newman (2001a, b; 2002a-g; 2003a, b). This region plays a significant international role in the extraction and processing of certain industrial minerals and lesser metallic minerals (Steblez and others, 2001)

\section{Albania}

Albania has produced chromite, copper, and nickel (Steblez, 2001). In 2001, only chromite was being mined. Industrial minerals are dolomite, gypsum, marble, and phosphate rock that have been worked intermittently during the past several years.

\section{Austria}

Although the mining industry has maintained a long tradition in Austria, the metal mining sector activity has declined during the past few years (Newman, 2003a). All the metal mines, except for the iron ore operation at Erzberg and the tungsten operation at Mittersill, were closed. Most of the growth in the mineral resources area was in the private sector production of industrial minerals, including illite, kaolinite, graphite, gypsum, anhydrite, lime, magnesite, salt, dimension stone, and talc. The important industrial minerals are graphite and talc. Austria was one of the world's largest sources of high-grade graphite with mines at Mühldorf, Kaisersberg, and Trieben. Gypsum is being mined at Abtenau, Moosegg, Grundlsee, Puchberg, Unterkainisch, and Weisenbach. Salt is being mined at Bad Ischl. Talc is being mined at Lassing, Rabenwald, and Weisskirchen. Tungsten is being mined at Mittersill, Felbertal, and Salzburg.

\section{Belgium}

Although the country is small, Belgium has a developed industrial minerals sector, including extraction of limestone and dolomite; silica sand; and construction materials with a wide range of different types of marble. Belgium, which has been an important producer of marble for more than 2,000 years, was recognized for the diversity and quality of its dimension stone. The socalled petit granite, which is a dark blue-gray crinoidal limestone, was one of the most important facing stones the country produces. All the marble quarries are in Wallonia. Red, black, and gray are the principal color ranges of the marble, most of which was exported. In addition, the mineralprocessing industry was a significant contributor to the Belgian economy in 2002 (Newman, 
2002a). The refining of copper, zinc, and minor metals and the production of steel, all from imported materials, were the largest mineral industries in Belgium.

\section{Bosnia and Herzegovina}

Bauxite and alumina are being produced in the southern and western part of the country (Stablez, 2001). Lead and zinc ore has been produced at Olovo and Vares, but the mining status at these operations in 2001 remained uncertain. Iron ore is being mined at Jablanica and Vares, and manganese is being mined at Bosanska Krupa. The country also has exploitable resources of barite, gypsum, magnesite, and rock salt.

\section{Bulgaria}

Exploration is occurring at the Krumovgrad copper deposit near the Greek border (Steblez, 2001). Navan obtained an exploration license in June 2000 that granted a $130 \mathrm{~km}^{2}$ area. Initial trenching in the Krumovgrad license area and found low sulfide epithermal gold hosted within sequences of Tertiary sedimentary rock and volcanic breccias.

Bulgaria's minerals industry produces ferrous and nonferrous metals, and industrial minerals such as barite, clay, dimension stone, gypsum, limestone (lime), rock salt, and silica (Steblez, 2001). On a world scale, however, Bulgaria's minerals industry is small and only of regional importance. Bulgaria's mines produce copper, iron, lead and zinc, and manganese. Additionally, byproduct gold, molybdenum, silver, and other metals are produced. Bulgaria's major copper deposits are in the Srednogorie-Panagjurishte region at the Asarel-Medet and the Elatsite surface mines and the Chelopech underground mine. Lead and zinc mining is occurring near Plovdiv in the Ossogovo Mountains in western Bulgaria, near the Thundza River in eastern Bulgaria, and in the Madan area, near the Greek border. Manganese mining resumed in 2001. Operations continue at the Chelopech polymetallic gold-copper-silver-pyrite massive sulfide mine (Steblez, 2001).

\section{Croatia}

Croatia continues to produce minor quantities of metals and industrial minerals, mainly for domestic consumption (Steblez, 2001).

\section{Czech Republic}

The mining and processing of industrial minerals and the production of construction materials continued to be of both domestic and regional importance (Steblez, 2001). The country has eight iron ore deposits that are uneconomic and no longer worked. Lead and zinc have not been mined in the Czech Republic for several years. The Czech Republic is well endowed with, and has produced a broad range of industrial minerals that met most of domestic construction and chemical industries's requirements, along with some exportation. The industrial minerals include clay, bentonite, diatomite, feldspar, gem pyrope, graphite, gypsum, and kaolin.

\section{Denmark}

Denmark lacks metallic mineral resources but has large reserves of industrial minerals, including clay, diatomite, phosphate, salt, and dimension stone (Kuo, 2002a, 2003a). 


\section{Estonia}

Industrial minerals, such as clay and silica sand are being mined (Kuo, 2002b).

\section{Finland}

European exploration activity focused in Finland (Kuo, 2002c) where the Arctic Platinum Partnership recently announced significant PGE resource estimates, and Riddarhyttan Resources $\mathrm{AB}$ has delineated substantial gold values at the Suurikuusikko project.

\section{France}

Metal and mineral industries continued production as of 2002 at about the same or slightly decreased rates; several industries, such as bauxite, and iron ore have steadily undergone changes during the past few years; this was especially true for iron ore, which is no longer mined (Neuman, 2002). Gold mining is mostly concentrated in Société des Mines du Bourneix's open pit and underground operations south of Limoges in the Saint Yrieix la Perche District and Mines d'Or de Salsigne's underground Salsigne Mine near Carcassonne. The Salsigne gold mine remained closed at year end. Mining of lead and zinc has completely ceased in France. Industrial minerals being mined are limestone for cement, clay, dimension stone, gypsum, mica, salt, silicon, sulfur, potash, and talc. Some bauxite waste dumps in the Languedoc region are being reprocessed; the resulting product was used by cement companies to correct alumina and the iron content of cement.

\section{Germany}

Most producing and processing facilities still in operation are small, except for large operations for potash (Newman, 2001a). Germany produces some limestone for cement, clay, kaolin, bentonite, barite, and graphite for internal consumption. Graphitwerk Kropfmühl AG was the only company that mined and processed graphite in Germany. The company operated a mine and plant at Kropfmühl, Passau. The largest German producer of gypsum is the Gipswerke Dr. Karl Würth $\mathrm{GmbH}$ that accounted for more than two-thirds of the country's gypsum production from a mine and plant in Lower Saxony. The second largest producer is Gyproc GmbH Banstoff Production \& Co. Gypsum mines are also operating in Lower Saxony. Kali und Salz AG operates six mines in four potash districts. Germany is the third largest potash producer in the world

\section{Greece}

Gold exploration in Greece has experienced additional slowdown (Newman, 2002b). Since the mid-1980s, the exploration for gold has resulted in the discovery of significant resources in the northern part of the country. Two projects for gold production from hydrothermal vein (epithermal) deposits were still in the permitting stage.

The mineral industry of Greece is a small but important part of the national economy (Newman, 2002b). Metallic commodities being lead and zinc being mined from base-metal deposits in northern Greece; alumina and aluminum from bauxite deposits; and ferronickel alloy from laterite-derived sedimentary nickel-iron deposits. Exports include bauxite, bentonite, nickel, and perlite. Greece is the largest producer of bauxite, magnesium, nickel, and perlite in the European Union. Large bauxite deposits at Boeotia and Phocis occur on the northern coast of the Gulf of Corinth. The Kassandra gold, lead, silver, and zinc mine has produced for more than 30 years. Nickel laterite mining is occurring at Agios Ioannis (underground), Evvia (open pit), and Kastoria (open pit) mines. The deposits are part of a belt that extends from Albania to Turkey. 
Greece is the world's second largest global producer of bentonite after the United States. Bentonite is extracted on Milos Island by open pit mining. Gypsum is mined from the island of Crete, pozzolan (a fine volcanic ash and related sedimentary rock) from Milos, and pumice from the island of Yali. The open pit magnesite mine at Yerakini in northern Greece is one of the largest in the world. In 2002, the Greek marble industry continued to play a leading role in the international dimension stone market as a result of continued marble production in almost all areas of the country coupled with a variety of uses of the marble and with many colors (ash, black, brown, green, pink, red, and multicolored). The marble industry was active in quarrying, processing, and sale of blocks and finished products. Natural zeolite is produced in northern Greece.

\section{Hungary}

After years of failed efforts to attract foreign investment, the exploration shaft and adit at the Recsk copper deposit, which was under care and maintenance, finally was closed, the equipment removed, and the facilities flooded in 1999 (Steblez and others, 2001). Gold exploration, however, was conducted in recent years in the area around the deposit. In 2001, the European Minerals Corporation (formerly Kazakhstan Minerals Corp.) explored for epithermal gold and silver deposits.

Hungary produces modest amounts of metals and industrial minerals, but no longer mines copper (Steblez, 2001). Aluminum was the only major nonfuel mineral produced in Hungary that was significant in terms of European mineral production. Hungary's production of primary aluminum remained modest owing to limited domestic sources of energy. Hungary produces a broad range of industrial minerals, including bentonite, kaolin, and perlite, and limestone for cement. The major bauxite deposit is in the Bakonyi district.

\section{Iceland}

Iceland has few identified mineral resources, although deposits of diatomite were mined (Kuo, 2003b), along with pumice and scoria, sand, and crushed stone.

Ireland

There was a reduction in Irish mineral exploration activity that was a reflection of concerns about the spread of hoof and mouth disease in livestock in 2001 (Newman, 2002d). Because of this reduction, there was an initiative by the Government to boost mineral exploration. The main focus for exploration and development of Ireland's lead-zinc deposits was Carboniferous sedimentary rock in the Midlands region. The mineralization is similar to that of the Mississippi Valley type in the United States and is hosted in carbonate units. Tournigan Ventures Corp. and European Gold Resources are exploring the Omagh gold project in County Tyrone, Northern Ireland (Newman, 2002d). The Omagh project, located $5 \mathrm{~km}$ southwest of the town of Omagh, covers an area of 189 $\mathrm{km}^{2}$. Previous exploration work by Rio Tinto Limited identified 15 mineralized structures in the eastern one-third of the concession.

Ireland's geology is favorable for the occurrence of base metals and industrial minerals (Newman, 2002d). Ireland is a major European Union producer of zinc. The main focus for exploration and development of Ireland's lead-zinc deposits was the Carboniferous sedimentary units of the Midlands region. The mineralization is similar to that of the Mississippi Valley type in the United States and is hosted in strata-bound carbonate units. Major mines are at Lisheen, Arcon, Galmoy, and Tara that is the largest zinc mine in Europe. A major gold vein deposit is being 
developed at the Tullybuck-Lisglassen property in County Monaghan. Industrial mineral production is mainly limestone for cement and lime, and gypsum.

Italy

Gold, lead, silver, zinc, and crude steel were being mined as of 2000 (Neuman, 2001). Except for gold, the outputs is not significant. Gold is mined from Furtei north of Cagliari. Furtei is the first gold mine in Italy. A most promising gold discovery is the Monte Ollasteddu project in eastern Sardinia. Minor lead and zinc comes from mines in Sardinia. Italy is the world's largest producers of pumice and feldspar, is a significant producer of cement, dimension stone, and marble. Other industrial minerals mines include: bauxite from the Olmedo karst bauxite deposit; limestone for cement from 55 quarries; gypsum from the Fassa quarry and processing plant; marble from many localities from the Italian Alps to Sicily, in hundreds of operations; and pumice from the Mediterranean Island of Lipari, $40 \mathrm{~km}$ off the northern coast of Sicily.

\section{Latvia}

The principal commodities produced in Latvia are limestone for cement and gypsum (Kuo, 2002b).

\section{Lithuania} 2002b).

The country's mineral industry is limited to industrial minerals as clay and limestone (Kuo,

\section{Luxembourg}

Mining in Luxembourg consists of small industrial mineral operations that produced material for domestic consumption (Newman, 2002a). These minerals include dolomite and limestone.

\section{Macedonia}

The Former Yugoslav Republic of Macedonia produces copper, gold, iron, lead, and zinc (Steblez, 2001). A processing and fabricating infrastructure also was established that allowed the production of not only these metals and their alloys, but also chromium, manganese, and nickel. Industrial minerals being produced are bentonite, feldspar, gypsum, dimension stone, and limestone (lime). Although mineral industry issues and events in 2001 were limited in scope, they included continuing interest in the Bucim open pit copper-gold mine in the southern part of the country.

\section{Malta}

The small mineral industry of Malta consists mainly of limestone and salt production for domestic consumption (Newman, 2003b).

\section{Moldova}

The only significant mineral resources in Moldova are local industrial minerals, including limestone for cement and lime, and gypsum (Levine and Wallace, 2001). 


\section{Netherlands}

The only mining operation is the extraction of limestone and salt (Newman, 2002e).

\section{Norway}

Norway has abundant natural nonfuel mineral resources that include feldspar, graphite, ilmenite, iron ore, limestone, nickel, and platinum-group metals. According to Kuo (2002c), exploration and exploitation of metals and minerals are extensive.

Minerals being produced included feldspar, graphite, ilmenite, iron ore, limestone, nickel, and platinum-group metals (Kuo, 2002c). The Outokumpu Oyj company of Finland ceased production at its Nikkel og nickel mine in Norway owing to depletion of reserves. Copper and nickel is being mined at Narvik. Iron ore is being mined at Mine at Mo i Rana. Industrial minerals being produced mainly for internal consumption are feldspar, graphite, and limestone, nepheline in the syenite mine at Stjernoy, olivine sand, and talc.

\section{Poland}

Poland is endowed with significant mineral resources, including copper, lead, zinc, silver, salt, and sulfur (Steblez, 2001). After Russia, Poland was the largest producer of copper in Europe and Central the study area in 2001, and was among the top 10 world producers of copper. The country is a significant producer of lead, zinc, silver, and salt for the study area.

In 2001, Poland's production of cadmium was about 330 tonnes, the highest level in more than 5 years. Owing to its strong association with lead-iron-sulfur minerals (galena and sphalerite), cadmium was produced as a byproduct of the lead and zinc mining in the Silesia-Cracow region. The major world copper mine in the Lubin area accounts for more than 3 percent of world copper production. Other major active copper mines are at Rudna and Polkowice-Sieroszowice. Gold is a byproduct of copper mining. Poland is a major European producer of lead and zinc in the southeastern part of the country in the Silesia-Cracow region at two underground mines at OlkuzPomorzany near Olkusz and at Trzebionka. Poland also is one the major world producers of silver, as produced as a byproduct of base metal mining, with about 7 percent of world mine production.

The major industrial minerals being extracted in 2001 were kaolin, construction-grade ceramic clay, sulfur, and construction grade quartz sand.Poland produced a broad range of industrial minerals including calcareous and silicate rocks, clay, feldspar, gypsum, magnesium, salt, and sulfur that serve country's chemical and construction industries.

\section{Portugal}

The 2002 structure of the mineral industry in Portugal could change in the near future because of continuing mineral exploration based on exploration models developed in the Iberian Pyrite Belt (IPB) (Newman, 2002f). Copper, gold, kaolin, lead, lithium, pyrite, and tin were some of the minerals targeted for exploration. The IPB is the prime area for exploration activity and would appear to have an above-average potential for success on the basis of an unusually high number of the large volcanogenic massive sulfide deposits discovered to-date.

The Iberian Pyrite Belt that is one of the most mineralized areas of Western Europe. Mining has occurred from Roman times through the 1990's (Newman, 2002f). In 1977 in this belt, the rich copper and tin deposits of Sociedade Mineira de Neves-Corvo were discovered and developed. This mine and the Panasqueira mine are the two major operations in the country. The Alentejanas S.A.R.L.mine is the country's largest producer of pyrite. The Lusosider Aços Planos S.A. and SN Servicos S.A. deposits are the major country producers. The Castromil gold-silver deposit is 
starting to be mined in northern Portugal. Major tin and tungsten mines are at Panasqueira and Feitais.

The Cimentos de Portugal S.A. (Cimpor) company has been an important producer of cement. Portugal's industrial minerals sector is a modern and efficient producer of a variety of materials, most notably dimension stone and minerals for the manufacture of ceramics. There is potential for increased production of granite, marble, and slate. Diatomite is being mined at Obidos and Rolica.

\section{Romania}

Romania's production of metallic minerals (aluminum, copper, lead and zinc, manganese, and iron ore), and industrial minerals are mainly of regional importance (Steblez, 2001). For metallic minerals, copper is mined primarily in the northeastern part of the country at mines at Baia Sprie, Cavnic, and Lesul Ursului, and in the southwestern part of the country at major mines at Moldova Noua, Rosia Poieni, and Rosia Montana. Gold is being developed and mined at Rosia Montana, the Certei gold-silver deposit in the Apuseni Mountains, and Teascu near Certej. Relatively low grade lead and zinc is being produced at underground mines in the Baia Mare, the Borsa, the Certej, and Rodna districts. The lead and zinc ores also contain copper and associated antimony, bismuth, cadmium, gold, and silver. Romania produces a broad range of industrial minerals including barite, various types of calcareous rock, feldspar and mica granite and pegmatite, clay, gypsum, graphite, silicon, and salt.

\section{Serbia and Montenegro}

Substantial parts of Serbia and Montenegro's mineral wealth, include kaolin, lead and zinc, nickel, and magnesium deposits occur in Kosovo (Steblez, 2001). Other deposits with prospective commercial value include chromite, aluminum, copper, limestone, marble, and quartz.

\section{Slovakia}

Slovakia has produced small quantities of copper, iron, gold, lead, and zinc. Industrial minerals that are produced mainly for local consumption are barite, clay, manganesium, magnesium, and salt (Steblez, 2001). Gold mining at the Banská Hodruša and Svetozár mines has ceased.

\section{Slovenia} 2001).

Slovenia's modest minerals production is mainly a variety of industrial minerals (Steblez,

\section{Spain}

Spain is a significant European producer of nonferrous and precious metals (Newman, 2002g). The main copper, lead, zinc, and precious metal deposits, from west to east, are at Tharsis, Scotiel, Rio Tinto, and Aznalcollar. Other major metallic commodities being mined are aluminum, lead, zinc, copper, and silver. Industrial minerals being produced include dimension stone, gypsum, kyanite, limesonte (lime), mica, and potash.

The Almadén mercury deposits accounted for the largest quantity of liquid mercury metal produced in the world, about one-third of the total amount of mercury ever produced. Mercury has 
been mined at Almaden, which was the largest mercury mine in the world, for more than 2,000 years. Although mining has ceased, enough mercury metal is stockpiled to satisfy world demand.

The Las Cruces copper deposit, located $20 \mathrm{~km}$ northwest of Seville, is being developed. Mining at the Aguas Teñidas copper-lead-zinc mine near Huelva was suspended in December 2001. The Lomero-Poyatos deposit in southern Spain is being developed. Gold is being mined at Carles and El Valle. The start of mining at the high-grade Charnela zone at El Valle boosted output significantly.

\section{Sweden}

Boliden Ltd. and North Atlantic Natural Resources entered into an agreement to explore in the Skellefte district in northern Sweden for base metals (Kuo, 2002d). Lake Resources of Australia reached a joint-venture agreement with BHP Billiton for Lake Resources' Moskosel Project in northern Sweden. The project area comprising two licenses totaling $520 \mathrm{~km}^{2}$ was considered highly prospective for silver-lead-zinc deposits that are similar to the classic Broken Hill-type mine in Australia. Boliden discovered a new zone of mineralization in zinc and silver adjacent to the Einarsson ore body at the Kristineberg polymetallic mine in northern Sweden. Continued exploration in the same area also revealed a new copper-gold-zinc zone.

Sweden was active in mining and exploiting base metals, iron ore, and industrial minerals (Kuo, 2002d). Copper is being mined at Aitik, Garpenberg, Kankberg, 68 Kristineberg, Langdal, Petiknas, and Renstrom. Gold is being mined at Björgdal; Aitik, Akerberg, Kankberg, Kristineberg, Langdal, Petiknas, and Renstrom. Lead is being mined at Garpenberg, Laisvall, Langdal, Petiknas, and Renström, and Zinkgruvan. Zinc is being mined at Garpenberg, Laisvall, Langdal, 112, and Renstrom, and Ammeberg. Base and precious metal mines are being mined at Storliden and Luossavaara-Kiiruunavaara. The Kiruna iron mine in northern Sweden is being extended under Lake Luossavaara. Industrial minerals are being produced mainly for internal consumption are feldspar at mines at Beckegruvan, Hojderna, and 50 Limbergsbo, Limberget and Riddarhyttan; graphite at Kringeltjärn and Woxna; and marble at Askersund.

\section{Switzerland}

The reserves of the small deposits of metalliferous ores in Switzerland are mostly depleted, and any new metal mining activities have been discouraged by the government for environmental reasons (Newman, 2003c). Consequently, metals have not been recently mined. Industrial minerals for local consumption are limestone for cement, gypsum, and salt.

\section{United Kingdom}

According to Newman (2002h), there is no current news on exploration in the United Kingdom except for PGE (platinum group elements) in Scotland.

Mining of ferrous and nonferrous metals in the United Kingdom has been declining since around 1970 because of depleting reserves (Newman, 2002h). The only tin mining activity was the marginal production of cassiterite by a tourist operation in Cornwall. The ore was smelted onsite to produce metallic tin for jewelry and ornaments. The industrial minerals sector provided a significant base for expanding the extractive industries. Industrial minerals being produced include aggregates, ball clay, china clay (kaolin), and gypsum, barite, china clay (kaolin), fluorspar, highgrade limestone, potash, salt, and silica sand. Major barite mines are at Derbyshire; kaolin mines at Cornwall and Evon; fluorspar mines at Weardale; and gypsum mines at Cumbria, Nottinghamshire, and Sussex. 


\title{
Mineral Exploration and Recent Mining in Russia, Belarus, and Ukraine
}

\author{
Exploration in Russia, Belarus, and Ukraine
}

In Russia, Belarus, and Ukraine, moderate exploration is being conducted for precious and base metals and industrial minerals (Wilburn, 2004). Because of the large and extensive sedimentary basins that onlap the margins of major mountain chains that contain abundant deposits, the region is considered under-explored. Whereas exposed regions of permissive geology hold potential for undiscovered resources, the areas where theses metal-rich belts extend beneath Mesozoic and Cenozoic sedimentary rocks are extremely prospective for undiscovered resources.

Russia, Belarus, and Ukraine experienced extensive exploration up to the time of their independence in the early 1990's (D.R. Wilburn, written communication, 2003; Wilburn, 2004). However, exploration was focused on commodities that were required by the centrally planned economy of the Former Soviet Union (FSU), and was not influenced by commodity market supply and demand economics. Many deposits that were mined during the time of the FSU were in remote areas and were developed regardless of economics. Conversely, many significant deposits (in today's terms) were not in production at the time of the collapse of the FSU (for example, Vasilkovskoye and Baqyrchik in Kazakhstan, and Zarmitan, and Amantaytau in Uzbekistan). Since their independence, the FSU countries have been trying to attract foreign investment into their minerals industries, but weak and unstable economies and governments, as well as weak metal markets, has slowed this process. With time, western companies have entered the region to explore for mineral resources and have begun to apply western geologic thinking and technology in their exploration programs. Most exploration has focused on gold and copper and to a lesser extent on zinc. Although few actual discoveries have been made over the last ten years, several significant areas of previously known mineralization have been re-evaluated in light of the new environment of: privatization; modern exploration concepts; modern geologic and tectonic analysis; modern mineral deposit models; and exploration by western companies. For example in the Russian Far East, the Juietta and Dukat hydrothermal gold and silver deposits have been reexplored and opened or enlarged with joint ventures with major Western mining companies. The following description of mineral exploration in Russia, Belarus, and Ukraine is adapted mainly from Levine and others (2001).

In Russia, exploration focused on the search for diamond, gold, and PGE (platinum group elements) (Levine and Wallace, 2001). On the Kola Peninsula, PGE resources reportedly totaled about 1,040 tonnes in the Pana tundra deposit, thus making it one of the world's richest PGE resources. Extensive drilling programs in Russia were ongoing at the Birkachan gold and Verkhotina diamond deposits, but exploration by foreign companies for new deposits in Russia during 2001 was limited.

For exploration for iron ore deposits, large quantities of what are termed in the Russian Reserve Classification System explored reserves occur in the Kursk Magnetic Anomaly (Levine and Wallace, 2001). These explored reserves are potential sources of new development.

The mines and plants of the Mining and Metals Company - Norilsk Nickel produce cobalt, copper, precious metals (gold, platinum group elements, and silver), selenium, industrial sulfur, tellurium, and other products (Levine and Wallace, 2001). The company is conducting exploration for new deposits containing these commodities. Mining and Metals Company - Norilsk Nickel accounted for 4.3 percent of Russian exports. Its share of Russia's GDP was 1.9 percent and of Russia's industrial output was 2.8 percent, which equaled 27.9 percent of the nonferrous industry's output. 
Diamond exploration continues in the Verkne-Modunskoye field which occurs $120 \mathrm{~km}$ from the city of Udachnyy in the Sakha (Yakutia) Republic where four pipes were discovered in Soviet times (Levine and Wallace, 2001). Mining each of the pipes separately was not considered to be feasible at that time. The project could succeed with modern technology if the pipes were mined together.

Ukraine is the largest country solely in area in Europe and was a major world producer of ferroalloys, ilmenite, iron ore, and manganese. As of 2001, there were no publically-available data on recent exploration in Ukraine (Levine and Wallace, 2001).

\section{Mining in Belarus}

Belarus is a major producer of potash and also produces other industrial minerals mainly for local uses (Levine and Wallace, 2001).

\section{Mining in Ukraine}

Ukraine is the largest country solely in area in Europe (fig. 2). At the end of the 1980's, Ukraine was a major global producer of mineral products (table 1) (Levine and Wallace, 2001). Since the breakup of the Soviet Union, Ukraine's mineral production has fallen precipitously. Nevertheless, in 2001, Ukraine was still a major world producer of ilmenite (titanium), iron ore, and manganese. The country has produced several other metallic mineral products, including cadmium, germanium, magnesium, mercury, nickel, rutile, uranium, zircon, and a large number of industrial minerals, including dolomite, graphite, kaolin, limestone, potash, quartz, salt, and a variety of building materials.

\section{Mining in Russia - Overview}

Russia accounts for about 14 percent of the world's total mineral extraction (table 1) (Levine and Wallace, 2001). Russia, along with other CIS countries, is a major producer of aluminum, antimony, arsenic, asbestos, barite, boron, bentonite, cobalt, copper, diamond, diatomite, fluorspar, gemstones, gold, indium, iron ore, magnesium, mica (sheet), molybdenum, nickel, phosphate, platinum-group metals, potash, rare-earth metals, salt, silicon, sulfur, and tin (Levine and Wallace, 2001). The mineral industry is of major importance to the Russian economy. Despite decreased total metal output compared with the Soviet Union period, Russia increased production of aluminum, lead, and zinc in 2001. It produced, however, only about 20 percent as much tin compared with the Soviet Union period. Because Russia covers a large part of Europe and eastern Asia, a relatively detailed summary of active mining is provided below.

Russia - Metallic Minerals Mining

Aluminum

Russia was the world's second largest aluminum producer after the United States in 2000 (Levine and Wallace, 2001). The industry is controlled by Russian Aluminum Company (RUSAL) and Siberian-Urals Aluminum Company (SUAL). RUSAL was the second largest aluminum company in the world in production of aluminum after Alcoa Inc.

\section{Antimony}


The Kadamzhay antimony mining and processing complex is extracting antimony ores from two mines at Kadamzhayskiy and Tereksayskiy (Levine and Wallace, 2001). Antimony also is being mined at the Sarylakh hydrothermal vein deposit in the Ust-Nera region, and the Sentachan hydrothermal vein deposit in eastern Siberia.

\section{Copper}

According to the International Copper Study Group in 1998, Russia possessed about 10 percent of the world's copper reserves, although a later study estimates the reserves at closer to 5 percent (Levine and Wallace, 2001). Approximately 70 percent of the country's reserves are at Norilsk in northern Siberia; 20 percent in the Urals Mountains; and 10 percent in the North Caucasus Mountains (fig. 3). The Urals Mountains GMK company is planning to invest $\$ 400$ million to develop the large Udokan sediment-hosted copper deposit in the TransBaikal region. Other major copper mines active in Russia are the Molodezhnyy, Sibay, and Uchali open pit volcanogenic massive sulfide mines in the Urals Mountains, the Aleksandrinskoye sediment-hosted copper deposit in the TransBaikal region, and the Letneye, and the Safyanovoskoye volcanogenic massive sulfide deposits.

Gold

In 2000, Russia mined 152.5 tonnes of gold, which included 11 tonnes of byproduct gold, and recovered 1.8 tonnes of gold from scrap (Levine and Wallace, 2001). A total of 639 enterprises mined gold in 2001. Lode deposits accounted for 45 percent of output. The country's two largest gold mining enterprises were the Omolon Gold Company, which was the largest mining company in the Magadan region, and the Polius Gold Company, which was located in the Krasnoyarsk region in southern Siberia. In 2002, more than 50 percent of Russia's gold production was projected to be from lode deposits; total mine output was more than 175 tonnes gold. In 2001, the Magadan region produced 30.15 tonnes of gold, The TransBaikal region produced 16 tonnes gold in 2001; the largest mine is at Lenzoloto that produced 8.4 tonnes gold in 2001. The Sakha Yakutia Republic mine in northern Siberia produced about 16 tonnes gold in 2001, and planned to produce 18 tonnes gold in 2002 .

Iron ore

According to the Minister of Natural Resources, Russia has more than 27 percent of the world's reserves of iron ore (Levine and Wallace, 2001). In 2001, 26 iron ore deposits were under development; reserves were adequate for 15 to 20 years at the 2001 rate of extraction. These reserves average, however, about 35 percent iron, which is low by world standards. The ratio of overburden to ore is four times greater on average than in other countries, which greatly increases the comparative cost of iron ore extraction. Russia's production of commercial iron ore was centered in mining enterprises that extract finely disseminated magnetite ores. The country's beneficiation technology is not state-of-the-art, and the quality of the concentrates with respect to iron and silica content did not often correspond with the demands of the metallurgical industry. In the Urals Mountains, major iron ore mines are active at Novotroitsk, Bakal, Kushva, Kachkanar, Matnitogorsk, and Rudnichnyy. In Siberia, major iron ore mines are active at Zheleznogorsk, Rudnogorsk, Abasa, Sheregesh, Tashtagol, and Vershina Tei.

Lead and Zinc 
In 2000, Russia was the second leading producer of lead and zinc in the CIS (Levine and Wallace, 2001). Most lead is mined in the Russian Far East, and most zinc was mined in the Urals Mountains (fig. 3). The Far East region accounted for 62.8 percent of mined lead and 9.2 percent of lead reserves; the eastern Siberia region, 17.7 percent and 75.9 percent; the Urals Mountains, 12.6 percent and 1.8 percent; the western Siberia region, 4.3 percent and 11.1 percent; and the North Caucasus, 2.4 percent and 2 percent. The Urals Mountains region produced 86.7 percent of the country's zinc and has 26.5 percent of zinc reserves; the Far East region, 9.2 percent production and 4 percent reserves; the western Siberia region, 2.1 percent production and 10.5 percent reserves; and the North Caucasus, 1.8 percent production and 2.2 percent reserves. The Dalpolimetall Mining and Metals Complex (GMK Dalpolimetall), which was a lead-zinc producer in Dal'negorsk in the Russian Southeast, produced more than 70 percent of Russia's lead concentrates and more than 14 percent of its zinc concentrates. Other major active lead-zinc mines are in the Altay Mountains region of southern Siberia, various mines in the Russian Far East, the Nerchinsk polymetallic deposit in the TransBaikal region, and the Sadon lead-zinc complex.

Molybdenum

Major active molybdenum mines are the Dzhida tungsten-molybdenum mine in the western TransBaikal region, the Sorsk mine in the southeastern part of the region, and the Tyrnyauz tungsten-molybdenum mine in the North Caucasus Mountains (Levine and Wallace, 2001).

Nickel

In 2000, the Mining and Metals Company - Norilsk Nickel, which was one of Russia's leading enterprises, and has metal mines and production facilities in eastern Siberia, the Taimyr Peninsula, and the Kola Peninsula, produced about 96 percent of Russia's nickel and 20 percent of the world's output of nickel. In the Norilsk area in northern Siberia, Mining and Metals Company Norilsk Nickel mined copper-nickel sulfide ores that also contain significant amounts of cobalt, copper, gold, and PGE (platinum group elements) (Levine and Wallace, 2001). Russia's remaining nickel was produced from laterite deposits in the Urals Mountains. In northern Siberia, the Mining and Metals Company - Norilsk Nickel's Polar Division operated six underground mines and one open pit mine. Two company mines at Pechenganickel and Severonickel enterprises on the Kola Peninsula produced copper and nickel. Nickel is also produced at the Ufaleynikel and Yuzhuralnikel mining complexes in the Urals Mountains.

Platinum-Group Metals

In addition to being the world's second largest producer of PGE (platinum group elements) after South Africa in 2001, Russia was the world's largest palladium producer because the ratio of palladium to platinum is higher in Russian ores than in South African ores (Levine and Wallace, 2001). Mining and Metals Company - Norilsk Nickel mined more than 90 percent of the country's PGE output from sulfide deposits in the Eastern Siberia Polar Division. An estimated 10 tonnes per year of PGE (mostly platinum) was also mined from placer deposits in the Russian Far East, Siberia, and the Urals Mountains. The Norilsk company is planning the opening two new underground nickel sulfide mines at Glubokiy and Skalistyy in the Piolar Division between 2000 and 2010. A new mine may be opened to develop nickel-rich ores in the northern part of the Talnakh deposit after 2015. 
Tin

Active tin mines are the Solnechnyy deposit in the Russian Southeast, and the Khinganskoye'olovo deposit in the TransBaikal region (Levine and Wallace, 2001). Other active tin mines are at Krustalnyy, Pevek, and Deputatskiy. Most of these deposits are in hydrothermallyaltered (tin) granites or related tin vein deposits.

Tungsten

As of 2000, tungsten mining was occurring at the Dzhida deposit in the TransBaikal region, the Kti-Teberdaskoye and Tyrnyauz deposits in the North Caucasus Mountains, and a number of other small deposits (Levine and Wallace, 2001). Other active tungsten mines are at Aginskoye in northeastern Siberia, the Antonovogorsk, and Bom-Grokhom deposits in the TransBaikal, the Iultin deposit in the Russian Northeast, and the Lermontov, Primor'ye, and Solnechnyy deposits in the central Russian Far East. Most of these tungsten deposits are in veins or hydrothermal alterations related to granite.

Vanadium

In 2001, vanadium was obtained as a byproduct of mining iron ore at the Kachkanar gabbro-hosted deposit in the Urals Mountains (Levine and Wallace, 2001).

Russia - Major Industrial Minerals Mining

\section{Diamond}

Russia has mined diamonds from kimberlite pipes at the Aykhal, Mirnyy, and Udachnaya, Zarnitsa, Mir, International, Komsomol'skaya, and Verkne-Modunskoye pipes areas in the Sakha (Yakutia) Republic in northern Siberia, and at the Lomonosov deposit and the Anabara alluvial (placer) deposit in northwestern Russia west of the Kola Peninsula (Levine and Wallace, 2001). Several of these deposits are slated for additional development and mining in the next few years.

Fluorspar

In 2000, most fluorspar was mined in in southeastern Russian and in the TransBaikal region (Levine and Wallace, 2001). A number of other small producers were also active. The major deposits are in hydrothermally-altered granite.

Phosphate

In 2000, Russia was mining either sediment-hosted phosphate rock or phosphate minerals in granitic rocks from the Kingisepp deposits in the Leningrad area, the Lopatino and Yegorevsk deposits in the Moscow area, the Silvinit and Verknekamsk deposits in the Urals Mountains, and at the Khibiny and Kovdor deposits on the Kola Peninsula (Levine and Wallace, 2001; Levine and others, 2002). 


\section{Mineral Exploration and Recent Mining in Northern Central Asia}

\section{Armenia}

A joint venture has been granted with exclusive rights to conduct geological exploration within a radius of $20 \mathrm{~km}$ of the Meghradzor and Zod gold deposits (Levine and Wallace, 2001). The last general assessment of reserves at the Kadzharan deposit, which was completed in 1985, listed more than 1.5 billion tonnes of explored reserves of copper-molybdenum ore, which was adequate to supply the nearby refinery near the deposit for several centuries.

Armenia has 18 copper, gold, iron, lead, molybdenum, silver, and zinc mineral deposits. Twelve deposits either are being mined or under development (Levine and Wallace, 2001). Coppermolybdenum mines are at Agarak and Zangezur, and a major gold deposit being developed is at Mgartskoye. Being developed are the Sotkskoye gold deposit, the Alaverdi, Kapan, and Shamlug copper deposits, the Akhtal polymetallic deposit, the Megradzor gold deposit, and the Lichkvazkoye, Terterasarskoye, and Shaumyanskiy Rayon gold-polymetallic deposits. The Razdanskiy Rayon iron deposit may also be developed.

\section{Azerbaijan}

Along with deposits that had been developed, a number of undeveloped minerals deposit, such as copper, gold, lead, silver, and zinc, have been prospected in the mountainous section of Azerbaijan (Levine and Wallace, 2001). Reserves have been established at some of these undeveloped deposits, and preparations were being developed. The Katekhskoye, Katsdagskoye, and Khikhinskoye deposits in the Sheki-belokanskiy zone on the southern slope of the Caucasus contain large amounts of copper, iron, lead, sulfur, and zinc. Owing to the complexity of these ores, however, new technologies will have to be developed to process them economically. Other copper deposits have been discovered in other areas of the Caucasus region of Azerbaijan, such as the Karadagskiy porphyry copper deposit in the Shamkhorskiy region.

Azerbaijan's mountainous regions contain a variety of nonfuel mineral deposits (Levine and Wallace, 2001). On the slope of the Caucasus Mountains, the Dashkasan iron and cobalt mine is the largest iron ore mining enterprise in the Caucasus Mountains area. The nearby Zaglik alunite deposit, the largest in the CIS, has been mined. The Kedabeksiy Rayon deposit has produced copper and byproduct gold and silver for more than a century. Another copper deposit in the Caucasus Mountains region is the Karadagskiy porphyry copper deposit. This region also produces facing materials from the Buzgovskiy and Shakhtakhtinskiy deposits, travertine from the Nakhichevan District, and marble from the Dashkasan deposit, and bentonite clay from the DashSalakhlinskoye deposit. Other industrial minerals produced mainly for local consumption are barite, limestone for cement, and clay.

\section{Georgia}

Georgia has explored deposits awaiting development (Levine and Wallace, 2001). Georgian mineral deposit analysts believe that developing the country's nonferrous, precious, and rare-metals deposits in the mountainous regions of the country should be top priority. Also, additional exploration could increase the reserves of gold and copper deposits. Potential exists for the development of known nonferrous, precious, and rare-earth metal and industrial mineral deposits. In addition, analysts believe that the country could benefit from technologically upgrading its mineral industry from exploration through all stages of production. 
In Georgia through 2000, the Chiat'ura manganese deposit and the Madneuli volcanogenic massive sulfide (copper-barite-lead-zinc) mine have played an important role in the revival of the country's mineral industry (Levine and Wallace, 2001).

\section{Kazakhstan}

Exploration has been conducted both by state mining companies and through joint ventures between the state and western mining companies (Levine and Wallace, 2001). Practically the entire minerals industry has undergone some degree of privatization. According to Kazakhstan's constitution, all mineral resources belong to the Government which awards contracts to develop these resources for specific time periods. Despite an influx of investment in its mineral industry, the industry still faced several problems that included the direction of investment funds. Almost no funds were being directed towards exploring for metallic ores, which will result in the depletion of most of these ores at existing enterprises by about 2020 .

In 2000, Kazakhstan's mining industry extracted 32 types of nonferrous, precious, and rare metals from which its metallurgical industry produced 70 types of metal products (Levine and Wallace, 2001). However no publically-available data are available on recent mining.

\section{Kyrgyzstan}

Exploration primarily for gold, high-quality silicon, PGE, precious stones, and tantalum was being conducted on a limited basis by using government funds (Levine and Wallace, 2001). Foreign investors were involved mainly in exploring for gold, including Barrick Gold Corporation, Cameco Corporation, Newmont Gold Company, Normandy Ltd., Phelps Dodge Corporation, TEK Corp., and others. Firms from Australia, Canada, Israel, Russia, and the United Kingdom also are conducting exploration. Total gold resources in Kyrgyzstan were estimated to be between 2,500 and 4,000 tonnes of which 1,000 tonnes gold was at identified deposits. As of January 1, 2000, the government had listed 471 tonnes of gold reserves at 13 lode and 22 placer deposits in which placer gold deposits contain about 6 tonnes. The largest gold deposits were Kumtor with 288 tonnes gold; Taldy-Bulak Levoberezhnyy, 80.4 tonnes gold; Dzheruy, 74.7 tonnes gold; and Makmal, 25.5 tonnes gold. About 45 deposits were considered to be of interest for future exploration, each estimated to have resources of more than 5 tonnes gold.

In 2000, the major operating mines were the Kadamzhay antimony mine, the Kumtor and Makmal gold mines, and the Khadarkan antimony-fluorspar-mercury mine (Levine and Wallace, 2001). The Kumtor gold mine in Kyrgyzstan is the only example of a new mine that was developed since the breakup of the FSU. The Jerooy gold deposit has undergone various stages of prefeasibility and feasibility studies in recent years (D.R. Wilburn, written communication, 2003). The Trudovoye tin mine in Kyrgyzstan is one of the largest tin deposits in the CIS with 149,100 tonnes and 95,600 tonnes of tin and tungsten reserves, respectively (Levine and Wallace, 2001). In 2001, the Tyan'Shan'olovo GOK company started to mine at the Sary-Dzhas deposit.

\section{Tajikistan}

For metallic mineral deposits in 2001, gold was being mined from the Dzhilau deposit (Levine and Wallace, 2001). Other mines include the Dzhizhikrutskoye antimony-mercury deposit, the Shing-Magianskiye antimony deposit, the Mosrif arsenic deposit, the Yuzhno-Yangikanskiy copper and bismuth deposit, the Ak-Arkhar boron deposit, the Takob and Krasnye Kholmy fluorspar deposits, placer gold deposits in the central and southern parts of the country, the Jilau, Taror, Yak-Suyskoye, Aprelevka, Chore, Kum-Manor, and Shahbas gold deposits, the 
Kansayskoye and Adrasman lead-zinc mines, the Bolshoy Kanimansur silver mine, and the Tafkon and Maykhura tin-tungsten mine. The Jilau gold deposit in has undergone various stages of prefeasibility and feasibility studies in recent years (D.R. Wilburn, written communication, 2003).

For industrial mineral deposits, the country mines decorative and precious and semiprecious stones, such as agates, amethyst, clinohumite, granite, laurite, marble for dimension stone, onyx marble, rubies, and spinel and tourmaline marble. Other industrial minerals being mined are marble at the Dal'yan the Dashtak, Tilyagul, and Pendzhikent deposits, dolomite from the Paskhivskoye deposit, salt from the Tut-Bulakskoye, Kamysh-Kurganskoye, and Khodzha-Muminskoye deposits, and limestone (lime) from the Kharangonskoye deposit.

\section{Turkmenistan}

A government program, entitled A Strategy for the Social-Economic Development of Turkmenistan to the Period of 2010, called for conducting exploration for iron ore, nonferrous metals, radioactive metals, rare metals, alunite, bentonite, fluorspar, phosphate, and zeolite and a range of construction materials (Levine and Wallace, 2001). This exploration was planned to result in the development of new deposits. In addition, limestone deposits, that are used in the chemical industry, were being explored in the Gowurdak-Kugitanskiy region.

In 2000, Turkmenistan's leading industrial mineral producers were the Arpaklenskiy and barite-witherite deposits and the Cheleken ozokerite mining enterprises, the Gaurdak sulfur plant, the Kara-Kum sulfur plant, and the Oglanlinskiy bentonite mining enterprise (Levine and Wallace, 2001). The Kara-Bogaz Gol lagoon off the Caspian Sea produces bischofite, epsomite, Caspian Sea salt, Glauber's salt, and sodium sulfate. In the western part of the country, iodine-bromine waters were being mined at the Boyadagskoye, Cheleken, and Nebitdag deposits. Other industrial minerals being mined are limestone (lime), facing stone, clay, potash, quartz sand, sodium sulfate, and sulfur.

\section{Uzbekistan}

An interesting venture has been the identification and extraction of gold from the more than 300 million tonnes of tailings at the Muruntau gold deposit in Uzbekistan (Levine and Wallace, 2001). The Zarafshan-Newmont Joint Venture became the first new significant mining operation in the former Soviet Union (Shayakubov and others, 1999). Exploration for diamonds was occurring with the assistance of Australian geologists and the Karashokho and Koksay sectors in the Navoi District may have significant resources.

In 2001 in Uzbekistan, exploration of the new Sautbayi tungsten deposit in the Kyzyl Kum was completed, and silver was being mined at the Kosmanachi, Okzhetpes, and Vysokovoltnoye deposits, and tungsten has been mined at the Koytash, Ingichka, Lyangar, and Ugat deposits. For industrial minerals, potash fertilizer was being mined at the Tyubegatanskoye deposit in the southern part of the country, along with fluorspar at the Suppatashskoye deposit, and and graphite at the Taskazganskoye deposit. Mining has occurred at the the Shava-Say rare-earth metal deposit, the Arab-Dasht, Khaudag, and Angren clay deposits, the Agata-Chibargata, Aurakhmat, Kengutan, and Kyzylbaur, Naugarzan, and Nugisken feldspar deposits, the Tadzhi-Kazgan graphite deposit, and the Dautashskoye manganese deposit. 


\section{Potential for Undiscovered Mineral Resources}

\section{Introduction}

Do undiscovered mineral resources remain in Greenland, Europe, Russia, and Northern Central Asia? Without a doubt, the answer is yes. Mineral resources produced from this region are from some of the largest and richest ore deposits in the world. The mere presence of a mineral deposit suggests that others are likely to exist because the processes that mineralize rock commonly form clusters and linear belts of ore deposits. In assessing regions potential for undiscovered mineral deposits, several questions should be addressed. Where will new deposits be found? What commodities will be present? How difficult will it be to find them? What are the environmental and societal issues related to discovering and developing new deposits, and how can they be addressed?

Two major points are important for assessing undiscovered mineral resources. First, mineral deposits are associated with large-scale geologic processes that reoccur in time and place. The decay of radioactive elements deep within the Earth provides the heat needed to drive the movement of materials in the Earth's mantle and tectonic plates. This movement of materials generates the magmas and hydrothermal fluids, fractures and faults, mountain ranges, and sedimentary basins that are important to the formation of various types of mineral deposits. Second, mineral deposits do not occur randomly; their distribution is intimately related to the geologic history of each continent. The movement of molten and solid rock in the mantle and tectonic plates is responsible for the development of cratons, deformational belts (orogens), faults, and rifts that are characteristic features of continental crust. The geologic architecture of each continent uniquely reflects the sequence of events that culminated in the distribution of rocks and ore deposits that are observed today. The more we know about the geologic fabric of each continent and the processes that control the regional and local distribution of mineral deposits, the better we can answer where new deposits will be found and what they will contain.

Our ability to find undiscovered deposits is affected by many factors. For example, how well has the geology of the continent been geologically mapped? There still are large parts of the world where the geologic framework of the continents is poorly mapped or largely unknown. Difficult terrain and poor access limit field investigations; in other regions, thick vegetation, soils, and younger rocks conceal the underlying geology that might suggest the presence and locations of undiscovered mineral deposits. In some cases, the policies of governments have restricted access to information about geology and mineral resources. The less that is known about an area, the more likely that mineral deposits are left undiscovered. Eastern Russia and Northern Central Asia are exploration frontiers; the basic geologic framework has been established, but the remoteness of these areas, together with overlying deposits of glacial material in northern Russia, and the existence of large Mesozoic and Cenozoic cover obscure much detail.

How well are the types of deposits of interest understood? Robust exploration models can be developed from the shared characteristics and associations of many deposits. If geologists understand the ore-forming process, a variety of geologic, geochemical, and geophysical tools can be developed to identify areas where undiscovered deposits may occur. For instance, porphyry copper deposits and volcanogenic massive sulfide deposits are well understood types of deposits. However, the creation of effective models is difficult for styles of mineralization for which only one or two mineral deposits are known.

How difficult will it be to find new mineral deposits? The approach that involves the least apparent risk to the exploration companies is to search in well-known areas with known ore deposits, well characterized geology, and where experience has shown what exploration techniques will work well. However, the expected returns may be lower because the remaining concealed 
deposits will be harder to find and may not be as large as those initially found. The most exciting discoveries will be in areas where no mineral deposits have been found previously. However, the opportunities for grass-root discoveries usually are in those areas where there exists the least amount of information; however this increases the cost of exploration and reduces the chances for a major discovery.

The geologic evolution of each continent has developed a unique set of environments in which mineral deposits may be found therefore the knowledge of the geology of an area is paramount for discovery of mineral deposits. The basic requirements to form a mineral deposit involve source of economic elements and geologic process. There must be a source area for the mineral material, a mechanism to transport it, and a means to concentrate and preserve. If any part of this system is missing, a mineral deposit will not be formed. Certain types of mineral deposits only occur in specific geologic settings. If that setting is not present, that type of mineral deposit will not be found. To find new deposits or to describe areas with potential for undiscovered (new) deposits, basic data must be compiled and interpreted on: (1) the geology of an area; (2) known mineral deposits in the area and their characteristics; and (3) modern information on the characteristics of mineral deposits types. Using this methodology, the following sections describe potential for undiscovered major mineral resource deposit types in Greenland, Europe, Russia, and Northern Central Asia.

\section{Greenland}

\section{Introduction}

In Greenland, moderate exploration is being conducted for precious and base metals (Wilburn, 2004). Greenland hosts moderate to potentially world-class deposits of: chromium, copper, gold, iron, lead, molybdenum, phosphorous, PGE (platinum group elements), rare-earth metals, silver, and zinc (table 2, fig. 8) (Kuo, 2002a, 2003a). Whereas exposed regions of permissive geology hold potential for undiscovered resources, the areas where theses metal-rich belts extend beneath the extensive ice cover and offshore may be prospective for undiscovered resources. Greenland is not currently a major producer of any commodity (table 1) (Kuo, 2002a).

\section{Areas Likely to Host Undiscovered Mineral Deposits}

\section{Gold, Nickel, and PGE (Platinum Group Elements)}

Large areas of the Archean shield contain greenstone belts, and sedimentary and volcanic rocks in early Proterozoic and older deformational belts (orogens). The quartz-carbonate-gold veins that are clustered near large fault zones in greenstone belts are an active exploration target. In the Nuuk area of southern Greenland, several occurrences are known, as well as the Nunalaq gold mine (Stendal and Secher, 2002). Although gold is currently the primary focus of exploration, these rocks may also host volcanogenic massive sulfide deposits and nickel deposits associated with high magnesium volcanic rock (komatiite). Exploration is focused on nickel and platinum-group elements in ultramafic (magnesium- and iron-rich) rocks that may be related to komatiites is occurring on Ammassalak Island in eastern Greenland (http://www.diamondfields.com/s/ Greenland.asp, March 23, 2004).

Large areas of magnesium- and iron-rich igneous rock formed during several mantle upwelling events. The most recent event produced the North Atlantic Igneous Province (Anderson and others, 2002) and contains the well-known Skaergaard intrusion deposit with palladium and gold (fig. 24). Exploration for nickel, copper, gold, and platinum-group elements continues at 
Skaergaard and in the Hammar Dal area in western Greenland. Other large provinces of flood basalts and related intrusions may host similar undiscovered deposits. These provinces include the Proterozoic Zig-Zag Dal Basalt Formation in northeast Greenland, the Proterozoic Thule Basin in northwest Greenland, and the Archean Fiskanaesset intrusion in western Greenland (Henriksen and others, 2000).

\section{Diamond}

Diamond occurs mainly in kimberlite that are derived mainly from mantle beneath Archean shields, and in associated surficial (placer) deposits. Kimberlite dikes occur along the western Greenland coast in the Nagssugtoqidian deformational belt (Woolley, 1987). Recent exploration has found approximately 600 diamonds from two areas (Jensen and Secher, 2004). Recent sampling of three kimberlitic occurrences in the Maniitsoq-Kangerlussuaq region of southwestern Greenland yielded 128 diamonds (http://www.geus.dk/cgibin/webbasen_nyt_uk.pl?id=1078678511\&cgifunction=form). The largest diamond is 0.74 by 0.63 by $0.54 \mathrm{~mm}$.

\section{Copper, Lead, and Zinc}

Carbonate sedimentary rock overlies the Archean shield adjacent to younger deformational belts (orogens). These rocks are adjacent to rocks deformed by Ellesmerian deformational belt. This young deformational belt may have displaced hydrothermal fluids that developed deep in the Franklinian basin into the reactive carbonate rocks that overlie the shield. In other areas of the world, this process forms stratabound (Mississippi Valley type) lead and zinc deposits.

Metal-bearing hydrothermal solutions are generated as water-rich sediments are buried deeply in basins within the Earth. These hydrothermal solutions can move towards the surface along fractures and faults, and form hot springs where they vent into the ocean. The hydrothermal solutions mix with ocean water and deposit large quantities of iron, zinc, and lead minerals onto mounds and layers on the seafloor. This is the process that formed the Citronen Fjord lead and zinc deposit in the Franklinian basin. This deposit occurs near the Navarana Fjord Escarpment that is a paleo-topographic feature marking the junction between shelf and trough sediments in the Franklinian basin (Van der Stijl and Mosher, 1998). If this feature controlled the movement of hydrothermal fluids out of the basin at the time of sediment accumulation, additional deposits like Citronen Fjord amy be discovered along the extension of this structure.

\section{Iceland}

Iceland, which is underlain mainly by young basalt that erupted from modern and ancient volcanoes. Associated with the volcanism was diatomite and silicon at the Lake Myvatn deposit (table 1). Additional deposits may be discovered, particularly in areas that are covered by thin units of young sedimentary rock. No active mineral exploration is listed in recent publications by Wilburn (2004) or by Kuo (2002c).

\section{Europe}

\section{Introduction}

In Europe, including Ireland and the United Kingdom, moderate exploration is being conducted for precious and base metals (Wilburn, 2004). Because of the large size and extensive 
sedimentary basins that onlap onto mountain chains with abundant known deposits, the region is considered underexplored for both metals and industrial minerals. The region hosts major and some world-class deposits (tables 1,2) (Levine and Wallace, 2001; Steblez, 2001). Whereas exposed regions of permissive geology hold potential for undiscovered resources, the areas where these metal-rich belts extend beneath Mesozoic-Cenozoic sedimentary rocks are extremely prospective for undiscovered resources.

\section{Ireland}

Ireland's geology includes several lithologic units and tectonic features that are favorable for the occurrence of several types of mineral resources from base metals to industrial minerals (Newman, 2002d). The main focus for exploration and development of Ireland's lead-zinc deposits is the Carboniferous sedimentary units of the Midlands region. This exploration, the discovery of relatively new base and precious metal deposits, and the favorable geologic setting suggests that additional deposits may be discovered, particularly in areas where the favorable units are overlain by thin Mesozoic and Cenozoic sedimentary cover.

\section{United Kingdom}

Mineral exploration has been active in the United Kingdom (Wilburn, 2004), andThe United Kingdom has produced barite, bentonite, bromine, chalk, fluorspar, gypsum, ilmenite, kaolin, limestone, potash, tungsten, tin (table 1). In addition to this production, the country has significant deposits of copper, halite, limestone, iron, potash, tin, tungsten, and zinc (table 2, figs. 7, 8). Additional deposits may be discovered, particularly in areas where the favorable units are overlain by thin Mesozoic and Cenozoic sedimentary cover.

\section{Europe}

The countries of western Europe (Austria, Belgium, Cyprus, Denmark, France, Italy, Luxembourg, Malta, Monaco, Netherlands, Norway, Poland, Portugal, Spain, Sweden, Switzerland) produce a wide variety of metals and industrial minerals (table 1), and have a large variety of known deposits (table 2, figs. 7, 8). In recent years, exploration in western Europe has been most active in Norway, Portugal, Italy (Sardinia), Spain, and Sweden (Wilburn, 2004). Some of the exploration is for new commodities (Wilburn, 2004), including PGE in Scotland. Base-metal exploration is occurring in Ireland and Sweden, in the Iberian Pyrite Belt in Portugal, in Sweden for silver-lead-zinc deposits, and in Spain for gold.

The countries of eastern Europe (Albania, Bosnia and Herzegovina, Bulgaria, Croatia, Czech Republic, Estonia, Finland, Greece, Hungary, Latvia, Lithuania, Macedonia, Moldova, Montenegro, Romania, Serbia, Slovakia, Slovenia) produce a wide variety of metals and industrial minerals (table 1), and have a large variety of known deposits (table 2, figs. 7, 8). In recent years, exploration has been most active in Bulgaria, Finland, Romania, Italy (Sardinia), and Slovakia (Wilburn, 2004). Some exploration targets are new commodities (Wilburn, 2004), including diamond in Finland, gold in Bulgaria, Greece, Hungary, and Romania, copper in Bulgaria, gold and silver in Bulgaria, Greece, and Hungary, and PGE in Finland. Others targets are in known deposits and districts, such as at the Suurikuusikko gold deposit in Finland, and the Rosia Montana goldsilver deposit in the Apuseni district in Romania.

With the above data on exploration, active mining, and knowledge of regional geology and mineral deposit types, the following several types of undiscovered mineral deposits may be found in Europe. 
1. In areas where other features exist for massive sulfide deposits in locally extensive Paleozoic and Mesozoic carbonate sedimentary rock, potential may exist for undiscovered stratabound zinc-lead deposits or sediment-hosted copper deposits.

2. Discovery of additional potash, phosphate, halite (salt) deposits may occur in areas underlain by extensive Proterozoic and Paleozoic sedimentary rock and evaporate sequences.

3. Large Archean shield areas with greenstone belts and sedimentary and volcanic rocks may contain undiscovered volcanogenic massive sulfide deposits and quartz-carbonate-gold vein deposits. Nickel deposits associated with high magnesium volcanic rocks may be discovered. Kimberlite with diamond may be discovered in Archean shields.

4. Additional sediment-hosted massive sulfide deposits may be discovere in Paleozoic and Mesozoic sedimentary basins that formed during the extension of continental crust with generaltion of hydrothermal fluids that vented to the ancient seafloor.

5. Considering the well-known association between some types of metal deposits and volcanic centers, Paleozoic and Mesozoic igneous arcs may contain volcanic centers that can be identified and explored, especially those with indications of associated metals or sulfur, or evidence of hydrothermal processes. In other well explored areas, these rock units contain substantial igneousrelated copper, molybdenum, tin, tungsten, fluorine, gold, silver, mercury, and bentonite deposits. Additional exploration may yield new discoveries of these commodities particularly beneath relatively thin Cenozoic volcanic and sedimentary cover.

6. Local areas with high-grade, reduced (oxygen-poor), carbon-rich metasedimentary rock, as at Zaval'e, may contain additional graphite deposits.

7. Areas with active volcanic arcs, as in Italy, may host additional feldspar, pumice, perlite, diatomite, hydrothermal gold and silver, barite, fluorine, and lead deposits.

8. Areas with extensively-eroded aluminum or iron-rich igneous rock, weathered to form bauxite or laterite deposits, may host additional deposits of this type, particularly in areas overlain by thin, younger sedimentary and volcanic rock cover.

\section{Ukraine, Belarus, and Russia}

\section{Ukraine and Belarus}

Ukraine and Belarus produce a wide variety of metals and industrial minerals (table 1), and have a large variety of known deposits (table 2, figs. 7, 8). With the above data on exploration, active mining, and knowledge of regional geology and mineral deposit types, the following summary can be made for areas likely to host undiscovered mineral deposits in Ukraine and Belarus.

1. The locally extensive carbonate sedimentary rocks in Belarus and Ukraine may host undiscovered stratabound zinc-lead deposits, sediment-hosted copper and manganese deposits, and industrial limestone deposits. 
2. Additional potash, limestone, similar carbonate-rock deposits, and gypsum, phosphate, halite (salt), and bromine deposits may occur in areas underlain by extensive Proterozoic and Paleozoic sedimentary rock containing evaporate units.

3. Large Archean and Proterozoic shields may contain additional banded-iron deposits, particularly in areas underlain by thin veneers of younger Paleozoic through Cenozoic sedimentary rock.

4. Major volcanic belts, such as the Inner Carpathian volcanic belt, may contain additional igneousrelated deposits, including granite-hosted copper and molybdenum, gold and silver epithermal vein, hydrothermal (skarn) copper, and related deposits.

5. Areas with known placer deposits, as the Malyshevskiy titanium and zirconium deposits, may contain additional deposits.

6. Areas with known rare-earth metal deposits in sodium- and postassium-rich (alkaline) igneous rocks, such as at Yastrebets, may contain additional deposits.

7. Local areas with high-grade, reduced (oxygen-poor), carbon-rich metasedimentary rock, such as at Zaval'e, may contain additional graphite deposits.

\section{Russia}

Russia produces a wide variety of metallic and industrial minerals (table 1), and has a large variety of known deposits (table 2, figs. 7, 8). In recent years, active exploration has focused on diamond, gold, and PGE (platinum group elements) (Lewis and Wallace, 2001). Recent explorations have been conducted for: PGE on the Kola Peninsula; gold across the country; diamond in Archean shield areas that have or are suspected to have kimberlite pipes; PGE in mafic (magnesium- and iron-rich) and ultramafic rock and in related placer deposits, gold and silver epithermal vein deposits; and banded iron formation in Archean and Proterozoic age sedimentary rock. With the above data on exploration, active mining, and knowledge of regional geology and mineral deposit types, the following summary can be made for areas likely to host undiscovered mineral deposits in Russia, particularly in areas underlain by thin veneers of sedimentary and volcanic rock.

\section{Urals Mountains and European Russia (West of Urals Mountains)}

1. The eroded Paleozoic island arcs preserved in the Urals Mountains may contain undiscovered deposits of magnesium- and iron-rich (mafic) intrusion-hosted titanium, iron, and PGE (platinum group elements) and related surficial PGE, granite-hosted (porphyry) copper, molybdenum, and gold, and volcanogenic massive sulfide (copper-lead-zinc-gold-silver) deposits. The island-arc units also may contain undiscovered iron iron-oxide copper-gold deposits related to volcanic rocks, and hydrothermal (skarn) iron deposits related to granitic intrusions. Local metamorphosed sedimentary rock may contain undiscovered metamorphic graphite deposits. The fragments of oceanic units (terranes) along the major fault (suture) zones may contain additional chromium, nickel, and PGE deposits related to mafic (magnesium- and iron-rich) and ultramafic rock.

2. West of the Urals Mountains, the eroded Paleozoic and Mesozoic volcanic and granitic arc rocks may contain concealed and undiscovered deposits of igneous-hosted rare-earth metals and 
phosphorous, nickel, copper, and granite-hosted tungsten, molybdenum, and gold, and related hydrothermal gold, surficial rutile and titantium deposits.

3. In European Russia, local new metamorphic graphite deposits may be discovered in highlymetamorphosed sedimentary rock.

4. In European Russia, new sediment-hosted copper deposits may be discovered in Proterozoic and Paleozoic marine sedimentary rock where other favorable features for the mineral deposit model exist.

5. In European Russia,, Proterozoic and Paleozoic marine carbonate sedimentary rock units and evaporate units may contain new deposits of gypsum, limestone potash, phosphate, halite (salt), and bromine.

6. In northwestern Russia, kimberlite diamond deposits are currently being explored on the Kola Peninsula and new deposits may be discovered. Also, new banded iron formation deposits may be found in Archean shields, and nickel-copper-PGE (platinum group elements), phosphate, and rareearth metal deposits may be discovered in magnesium- and iron-rich (mafic) plutonic rocks of Proterozoic age.

\section{Siberia and Russian Far East}

1. In Siberia, the large Archean shields contain greenstone belts and overlying sedimentary and volcanic rock in early Proterozoic deformational belts. These units have potential for undiscovered volcanogenic massive sulfide deposits and quartz-carbonate-gold vein deposits. In addition, nickelcopper-PGE-cobalt deposits, associated with high magnesium volcanic and plutonic rocks, may continue to be discovered.

2. Major regional faults are important controls for magmatic and hydrothermal systems and their associated metals. In the Altay Mountains in southern Siberia, major faults (suture zones), that bound individual island arc belts, are the location of many significant gold deposits related to fault zones, granitic intrusions, and metamorphic rocks. The most important of these zones is the 3,000$\mathrm{km}$ long suture that resulted from the collision between rock units in the Altay Mountains (southwestern Siberia) and the Urals Mountains arc (fig. 3). Undiscovered igneous rock-related and hydrothermal mineral deposits are likely to occur in areas where the major faults continue under the cover of young sedimentary or volcanic rock units. A thorough description of Atay Mountains metallogeny is found in Yakubchuk and others $(2001,2002)$.

3. The eroded Paleozoic igneous arcs of the Altay Mountains contain world-class copper-gold deposits related to granitic intrusions (porphyry copper-gold and hydrothermal (epithermal) goldsilver). The back-arc basins that formed adjacent to the Paleozoic island arcs are host to significant deposits of copper, lead, and zinc deposits related to sedimentary rock. This region has potential for addition al undiscovered deposits.

4. In northern and central Siberia, more diamond deposits are likely to be discovered in kimberlite intrusions. 
5. The Norilsk-Talnakh complex in northern Siberia contains mafic (magnesium- and iron-rich) and ultramafic related PGE-nickel-copper-chrome deposit, and is a major world-class deposit. Although this region is well explored, discoveries may continue as more sophisticated tools are developed to image rocks associated with mineral deposits at depth beneath Mesozoic and Cenozoic cover.

6. In northern and central Siberia, the Archean shield and overlying Proterozoic sedimentary units locally contain banded iron formation deposits. Additional detailed geophysical surveying may lead to new deposits under thin Paleozoic and younger cover.

7. In Archean shield units in northern Siberia, highly-metamorphosed, carbon-rich sedimentary rock contains graphite deposits. With additional geophysical studies, new metamorphic graphite deposits may be discovered at depth or underneath younger cover.

8. In Archean shield units in northern Siberia, where younger, back-arc alkaline (sodium- and potassium-rich) plutonic and associated alkaline volcanic rocks intrude, or overlie the older shield rocks, additional discoveries of phosphate (in the mineral apatite), rare-earth metals, and titanium deposits may occur.

9. In Sibera and the western part or the Russian Northeast, additional geophysical studies may reveal areas with Proterozoic and Paleozoic carbonate rock that may host undiscovered stratabound zinc-lead deposits, particularly at depth or under younger cover.

10. Major Proterozoic, Paleozoic, Mesozoic and Cenozoic sedimentary basins in western and northern Siberia may host additional aluminum (bauxite), uranium, gypsum, salt, potash, boron, magnesium, iodine, and bromine deposits related to sedimentary rocks and brines.

11. In the southern Russian Far East, continental-margin fragments intruded by early Paleozoic igneous arcs may contain additional fluorite greisen and rare-earth metal deposits.

12. Around the margins of the North Asian (Siberian) craton, where fragments of younger, mainly continental-margin or island arcs were accreted from the middle Paleozoic through the middle Cenozoic, new deposits related to generation of hydrothermal fluids during collisions may be found. These deposit types include granited-hosted (porphyry) copper and molybdenum, hydrothermal (skarn) copper, antimony, gold, tin, and copper-zinc-lead-gold-silver (polymetallic) vein, and tungsten vein.

13. In the Russian Far East, in fragments of accreted and eroded island arcs, as in the Koryak Mountains, additional copper-nickel-PGE (platinum group elements) deposits may be found in magnesium- and iron-rich (mafic and ultramafic) plutonic rocks. Additional geophysical studies may reveal areas where undiscovered deposits occur at depth or under younger cover.

14. Sedimentary-rock-hosted hydrothermal gold deposits (Carlin-type) may be found in Siberia and the Russian Far East. This relatively new deposit type, that is a major source of gold in the United States, consists of submicroscopic grains of gold that are often hosted in black shale. In addition, these deposits also contain minor arsenic, mercury, thallium, and antimony. Many of the polymetallic deposits in Siberia and the Russian Far East contain antimony minerals, some are hosted in black shale, and some have gone through a tectonic and thermal history similar to the 
sedimentary-rock-hosted deposits in the United States. These features make these areas excellent candidates for undiscovered sedimentary-rock- hosted gold deposits.

15. The geologically young subduction-related, continental-margin igneous arcs (Kurile and Kamchatka region) in the Russian Far East (fig. 3) will continue to be favorable for new discoveries of hydrothermal and igneous deposits of copper, molybdenum, gold, lead, zinc, silver, tin, tungsten, and mercury that are related to emplacement and cooling of granitic rock.

16. The accreted fragments of Mesozoic and early to middle Cenozoic continental-margin and island arcs in the Russian Far East will continue to be favorable for new discoveries of volcanogenic massive sulfide and sedimentary-exhalative copper-lead-zinc deposits. Additional geophysical studies may reveal areas where undiscovered deposits occur at depth or under younger cover.

17. Volcanoes (fig. 10) with large collapsed craters occur in the Kurile and Kamchatka continentalmargin igneous arcs along the eastern margin of the Russian Far East (figs. 3, 6). Base and precious metal deposits are associated with volcanoes, particularly in areas with hydrothermally altered rock or with explosion features. With additional detailed geologic mapping and geophysical surveys, these rock units may contain substantial copper, molybdenum, gold, silver, and mercury deposits, particularly underneath relatively thin volcanic and sedimentary cover.

18. Extensive surficial (placer) gold, PGE, and diamond deposits occur in Siberia and the Russian Far East. With additional geochemical and geophysical surveys, new deposits may be located beneath thin veneers of and extensive Cenozoic sedimentary and volcanic rock.

\section{Northern Central Asia}

\section{Introduction}

The countries of Northern Central Asia produce a wide variety of metallic and industrial minerals (table 1) and have a large variety of known deposits (table 2, figs. 7, 8). The region hosts world-class belts of deposits of copper and gold related to granitic intrusions and gold related to fault zones, and significant copper and zinc deposits related to volcanic and sedimentary rock. The areas where theses metal-rich belts extend beneath Mesozoic and Cenozoic sedimentary rocks are prospective for undiscovered resources. The region also contains world class resources of salt, iodine, and bromine, particularly in the areas marginal to the Caspian Sea (Levine and Wallace, 2001). As with metal deposits, the region is considered underexplored for industrial mineral deposits and considerable potential exists for undiscovered deposits.

In recent years, metals exploration has been very active with a focus on diamond, gold, and PGE (platinum group elements) (Levine and Wallace, 2001). Recent explorations have been conducted for gold vein deposits in Armenia, base and precious metal and porphyry copper deposits in Azerbaijan and Georgia, gold, silicon, PGE, and tantalum deposits in Kyrgyzstan, iron ore, nonferrous metals, radioactive metals, rare metals, alunite, bentonite, fluorspar, phosphate, and zeolite deposits in Turkmenistan, and gold and diamond deposits in Uzbekistan.

\section{Altay Mountains}

The eroded Paleozoic igneous arcs of the Altay Mountains contain world-class copper-gold deposits related to granitic intrusions (porphyry copper-gold), such as the Kounrad deposit in 
Kazakhstan, and the Almalyk district in the Tien Shan Mountains of Uzbekistan (table 2). The back-arc basins, that formed adjacent to the Paleozoic island arcs in the region, host significant copper, lead, and zinc deposits related to sedimentary rock (sediment hosted copper, sedimentary exhalite lead and zinc). These include the world class Dzhezkazgan copper deposit, $\backslash$ and the Zhairem and Tekeli lead and zinc districts, all located in Kazakhstan.

Major faults (sutures), that bound individual island arc belts, are the location of many significant gold deposits related to fault zones and metamorphic rock. The most important of these zones is a 3,000-km long suture that formed during the collision between the Altay Mountains and the Urals Mountains arc. This fault zone extends from the eastern Urals Mountains to the southern Tien Shan Mountains (fig. 3). This zone contains the world-class Muruntau gold deposit, and the Daugiztau, Zarmitan, Kokpatos deposits in Uzbekistan, the Jilau gold deposit in Tajikistan, and the Kumtor and Jerooy gold deposits in Kyrgyzstan. A more thorough description of Atay Mountains metallogeny is found in Yakubchuk and others $(2001,2002)$.

This Altay Mountains are relatively underexplored. Additional, detailed geologic mapping and detailed geochemical and geophysical surveys may reveal new deposits, particularly under thin veneers of younger Mesozoic and Cenozoic sedimentary and volcanic rock.

\section{Southern Urals Mountains}

The fragments of Paleozoic island-arcs in the southern Urals Mountains contain copper-zinc volcanogenic massive sulfide deposits and iron deposits related to volcanic rocks and granitic intrusions (iron-oxide copper-gold, and hydrothermal (skarn) iron deposits (table 2). The significant deposits are the 50 Let Octyabrya and Priorskoe copper-zinc deposits near the northern Kazakhstan border (Seltmann and others, 2003). The suture zone exposed on the west side of the Urals Mountains contains chromium, nickel, and PGE deposits related to mafic (magnesium- and ironrich) and ultramafic rocks. The significant deposit is at Almaz-Zhemchuzhina in the southern Urals Mountains (Seltmann and others, 2003). This region is relatively underexplored, and additional, detailed geologic mapping, and detailed geochemical and geophysical surveys may reveal new deposits, particularly under thin veneers of younger Mesozoic and Cenozoic sedimentary and volcanic rock.

\section{Mesozoic-Cenozoic Sedimentary Basins}

Mesozoic and Cenozoic sedimentary basins in the region host aluminum (bauxite) and uranium deposits in southern Kazakhstan and Uzbekistan (table 2). These basins locally contain world-class resources of salt, potash, boron, magnesium, iodine, and bromine, particularly in lowlying areas marginal to the Caspian and Aral Seas (Mukhin, 1997; Rastsvetaev, 1997; Yakubchuk, 1997). Subsurface exploration may reveal additional major deposits.

\section{Caucasus Mountains}

The mineral resources of the Caucasus Mountains are similar to that of the Altay and Urals Mountains because of similar geologic and tectonic events (table 2). Copper and iron deposits related to hydrothermally-altered granite (porphyry copper and iron skarn) occur in the Lesser Caucasus Mountains of Armenia and Azerbaijan. These deposits include the Kadzharan copper deposit in Armenia, and the Dashkesan iron district in Azerbaijan (Economic and Social Commission for Asia and the Pacific (ESCAP), 2000; Singer and others, 2002). Copper and zinc volcanogenic massive sulfide deposits occur in the Greater Caucasus Mountains, including deposits in the Bolnisi district in Georgia. This region is relatively underexplored, and additional, detailed 
geologic mapping, and detailed geochemical and geophysical surveys may reveal new deposits, particularly under thin veneers of younger Mesozoic and Cenozoic sedimentary and volcanic rock.

\section{Acknowledgements}

We thank Dave R. Wilburn for providing nonfuel mineral exploration data; Cliff D. Taylor and Stephen G. Peters for constructive scientific reviews; Richard M. Levine for review of, and assistance with commodity descriptions and interpretations; and John D. Horton (Env. Careers Org./USGS - Reston) for editing illustrations, GIS work and compilation of this report.

\section{References Cited}

Ager, D.V., 1980, Geology of Europe: Wiley, New York, 535 p.

Antony, B.T., Werner, W., Sinclair, D., and Amey, E.B., 1998, International Strategic Mineral Issues summary report-tungsten: U. S. Geological Survey Circular 930-O, 71 p.

Andersen, J.C.Ø, Power M.R., and Momme, Peter, 2002, Platinum-group elements in the Palaeogene North-Atlantic igneous province, in Cabri, L.J., ed., The Geology, Geochemistry, Mineralogy and Mineral Beneficiation of Platinum-Group Elements: Canadian Institute of Mining and Metallurgy Special Volume 54, p. 637-667.

Appel, P.W.U., 2004, Gold in the Nuuk region of West Greenland: Geological Survey of Denmark and Greenland (GEUS) Exploration and Mining in Greenland Factsheet No. 6, 2 p.

Ariunbileg, Sodov, Biryul'kin, G.V., Byamba, Jamba, Davydov, Yu.V., Dejidmaa, Gunchin, Distanov, E.G., Dorjgotov, Dangindorjiin, Gamyanin, G.N., Gerel, Ochir, Fridovskiy,V.Yu., Gotovsuren, Ayurzana, Hwang, Duk Hwan, Kochnev, A.P., Kostin, A.V., Kuzmin, M.I., Letunov, S.A., Li, Jiliang, Li, Xujun, Malceva, G.D., Melnikov, V.D., Nikitin, V.M., Obolenskiy, A.A., Ogasawara, Masatsugu, Parfenov, L.M., Popov, N.V., Prokopiev, A.V., Ratkin, V.V., Rodionov, S.M., Seminskiy, Z.V., Shpikerman, V.I., Smelov, A.P., Sotnikov, V.I., Spiridonov, A.V., Stogniy, V.V., Sudo, Sadahisa, Sun, Fengyue, Supletsov, V.M., Timofeev, V.F., Tyan, O.A., Vetluzhskikh, V.G., Xi, Aihua, Yakovlev, Y.K., Yan, Hongquan, Zhang, Qiusheng, Zhizhin, V.I., Zinchuk, N.N., and Zorina, L.M., 2003, Significant metalliferous and selected nonmetalliferouis lode deposits, and selected placer districts for Northeast Asia: U.S. Geological Survey Open-File Report 03-220, CD-ROM.

Benbow, John, 1991, Finland's mineral industry-turning to stone: Industrial Minerals, no. 283, p. 19-37.

Bettles, Keith, 2002, Carlin-type gold deposits: a summary, in Cooke, D.R., and Pongratz, June, eds., Giant ore deposits: characteristics, genesis and exploration, Centre for Ore Deposit Research, University of Tasmania, GPO Box 252-79, Hobart, Tasmania, Australia 7001, p. 191194.

Blundell, D., Freeman, R. and Mueller, S., eds., 1992, A Continent Revealed. The European Geotraverse: Cambridge University Press, Cambridge, 275 p.

Boggs, Sam, Jr., 1987, Principles of sedimentology and stratigraphy, Merrill, Columbus, 784 p.

Bolger, Rachel, 1996, Czech minerals \& markets-- Rebirth out of revolution?: Industrial Minerals, no. 348, p. 41-63.

Bond, A.R., and Levine, R.M., 2001, Noril'sk nickel and Russian platinum-group metals production: Post-Soviet Geography and Economics, v. 42, p. 77-104.

Bouladon, J., 1989, France and Luxembourg, in Dunning, F.W., Garrard, P., Haslam, H.W., and Ixer, R.A., eds., Mineral deposits of Europe, volume 4/5: Southwest and Eastern Europe, with 
Iceland: London: The Institution of Mining and Metallurgy and the Mineralogical Society, p. 37104.

Briskey, J.A., Schultz, K.J., Mosesso, J.P., Horwitz, L.R., and Cunningham, C.G., 2001, It's time to know the planet's mineral resources: Geotimes, v. 46, no. 3, (March), p. 14-19.

Briskey, J.A., Schultz, K.J., Mosesso, J.P., Horwitz, L.R., and Cunningham, C.G., 2002, Environmental planning issues and a conceptual global assessment of undiscovered nonfuel mineral resources, in Briskey, J.A. and Schulz, K.J., eds., Agenda, extended abstracts and bibliographies for a Workshop on Deposit Modeling, Mineral Resources Assessment, and Their Role in Sustainable Development - $31^{\text {st }}$ International Geological Congress, Rio de Janeiro, Brazil [extended abstract]: U. S. Geological Survey Open-File Report 02-423, p. 7-10.

Bristow, C.M., Palmer, Quentin, Witte, G.J., Bowditch, Ivor, and Howe, J.H., 2002, The ball clay and china clay industries of southwest England in 2000, in Scott, P.W., and Bristow, C.M., eds., Industrial minerals and extractive industry geology: London, Geological Society, p. 17-41.

British Geological Survey, 2004, Dene Quarry: www.bgs.ac.uk/foundationweb/Aggregates_Dean.html.

British Sulphur Corporation Limited, 1987, A world survey of phosphate deposits: London, The British Sulphur Corporation Limited, 274 p.

Buryak, V.A., 1980, Metamorphism and ore formation: Nedra, Moscow, 256 p. (in Russian).

Chermette, A., 1969, Fluorite; mineralogy, deposits, industrial applications, economic aspect: Bulletin Mensuel - Societe Linneenne de Lyon, v. 38, p.147-160 (in French).

Commission for Geological Map of the World, 1972, Carte métallogénique de l'Europe; Liste de gites mineraux, feuille 2: Europe N (Stockholm): Bureau de Recherche Géologiques et Minières and United Nations Educational Scientific and Cultural Organization, 16 p.

Commission for Geological Map of the World, 1973b, Carte métallogénique de l'Europe; Liste de gites mineraux, feuille 5: Europe Centre (Prague): Bureau de Recherche Géologiques et Minières and United Nations Educational Scientific and Cultural Organization, $32 \mathrm{p}$.

Commission for the Geological Map of the World, 1968-1982, Cartemetallogenique de l'Europe et des pays limitrophes: Bureau de Recherche Géologiques et Minières, 9 sheets, scale 1:2,500,000. Condie, K.C., 1997, Plate tectonics and crustal evolution, Fourth Edition: Butterworth-Heinemann, Oxford, UK, $282 \mathrm{p}$.

Cox, D.P., and Singer, D.A., eds., 1986, Mineral deposit models: U.S. Geological Survey Bulletin 1693, 379 p.

Cox, D.P., Lindey, D.A., Singer, D.A., and Diggles, M.F., 2003, Sediment-hosted copper deposits of the world: Deposit models and databases: U.S. Geological Survey Open-File Report 03-107. http:// geopubs.wr.usgs.gov/open-file/of03-107/

Crockett, R.N., Chapman, G.R., and Forrest, M.D., 1987, International Strategic Minerals Inventory summary report-Cobalt: U.S. Geological Survey Circular 930-F, 54 p.

Cunningham, C.G., Zientek, M.L., Bawiec, W.J., and Orris, Gretta, this volume, Geology and nonfuel mineral deposits of Latin America and Canada: U.S. Geological Survey Open-File Report, in press.

Czech Republic Factbook, 2004: http://www.factbook.net/czech_republic/.

Dardenne, M.A., and Schobbenhaus, Carlos, 2000, The metallogenesis of the South American platform, in Cordani, U.G., Milani, E.J., A.Thomaz, Filho, and Campos, D.A., eds., Tectonic evolution of South America: $31^{\text {st }}$ International Geological Congress, Rio de Janeiro, Brazil, p. 755-850.

DeBeers, 2004, Diamond Geology, 33p. ONLINE.Available: http://debeersgroup.com/exploration/content/ diamond/Geology.pdf. 
Derry, D.R., 1980, World atlas of geology and mineral deposits: Mining Journal Books, Ltd, London, $111 \mathrm{p}$.

DeWit, M.J. and Ashwal, L.D., eds., 1997, Greenstone belts: Oxford Monographs on Geology and Geophysics No. 35: Clarendon Press, Oxford, 809 p.

DeYoung, J.H., Jr., Sutphin, D.M., and Cannon, W.F., 1984, International Strategic Minerals Inventory summary report--Manganese: U.S. Geological Survey Circular 930-A, 22 p.

Doglioni, C., and Flores, G., 2001, Italy, in Rampino, M.R., ed., The Earth Sciences Encyclopedia Online (ESEO): SpringerLink Reference Works, (http://reference.kluweronline.com/?xmlid=6).

Dyuzhikov, O.A., Dictler, V.V., Strumin, B.M., Mkrtychan, A.K., Sherman, M.L., Sluzhenikin, S.F., and Lurie, A.M., 1988, Geology and ore mineralization of Norilsk region: Nauka, Moscow, 279 p. (in Russian).

Ermolov, P.V., 2000, Granite-related ore systems of Kazakhstan, in Kremenetsky, A., Lehmann, B, and Seltmann, R., eds., Ore-bearing granites of Russia and adjacent countries: IMGRE, Moscow, Russia, 1 p. 83-96.

Economic and Social Commission for Asia and the Pacific (ESCAP), 2000, Atlas of mineral resources of the ESCAP region, v. 15, Geology and mineral resources of Azerbaijan: New York, United Nations. 216 p. with maps.

Escher, Arthur and Watt, W.S., 1976, Summary of the geology of Greenland, in Escher, Arthur and Watt, W.S., eds., Geology of Greenland: Copenhagen, Denmark, The Geological Society of Greenland, p. 460-487.

European Association of Feldspar Producers, 2004: http://www.ima-eu.org/en/felindex.html.

Faulk, Lennart, and Hauber, Dietrich, 1990, The Eastern German industrial minerals contribution: Industrial Minerals, no. 279, p. 24-49.

Franklin, J.M., 1993, Volcanic associated massive sulfide deposits, in Kirkham, R.V., Sinclair, W.D., Thorpe, R.I., and Duke, J.M., eds., Mineral Deposit Modeling, Geological Association of Canada Special Paper 40, p. 315-334.

French Research Institute for Exploitation of the Sea, 2000, Polymetallic nodules: French Research Institute for Exploitation of the Sea, Centre de Brest, Département Géosciences Marines, June 30, 2004, at: http://www.ifremer.fr/drogm_uk/Realisation/Miner/Nod/texte/txt1_2.html, 4 p.

Gaal, G. and Parkkinen, J., 1993, Early Proterozoic ophiolite-hosted copper-zinc-cobalt deposits of the Outokumpu type, in Kirkhan, R. V., Sinclair, W. D., Thorpe, R.I., and Duke, L. M., Mineral deposit modeling, GAC Special paper 40, Geological Association of Canada, 798 p.

Gablina, I. F., 1981, New data on formation conditions of the Dzhezkazgan copper deposit: International Geology Review, v. 23, p. 1,303-1,311.

Garrett, D.E., 1996, Potash-deposits, processing, properties and uses: New York, Chapman \& Hall, $734 \mathrm{p}$.

Geological Survey of Canada, 1995, Generalized geological map of the world and linked databases: Geological Survey of Canada Open File 2915d, on CD.

Gill, Gary, 2003, Manganese nodules: Galveston, Texas A\&M University at Galveston, Department of Marine Sciences, publicly available on the web on June 29, 2004, at: http://gill.tamug.tamu.edu/MARS615/Manganese\%20Nodules.htm, 26 p.

Gold in Finland, 2004, Geological Survey of Finland: http://www.gsf.fi/explor/eco_gold_frame.htm

Gold Mines of Sardinia, 2004: www.gmsplc.com/sitemap.html.

Goldberg, I, Hammerbeck, E. C. I., Labuschange, L. S., and Rossouw, C., 1992, International Strategic Minerals Inventory summary report-vanadium: U. S. Geological survey Open-File Report 930-K 45 p. 
Goodfellows, W.D., Lydon, J.W., and Turner, R.J.W., 1993, Geology and genesis of stratiform sediment-hosted (SEDEX) lead and zinc-silver sulphide deposits, in Kirkham, R.V., Sinclair, W.D., Thorpe, R.I., and Duke, J.M., eds., Mineral Deposit Modeling, Geological Association of Canada Special Paper 40, p. 201-252.

Goncharov, V.I., 1995, Geologic review of commercial mineralization types of the OkhotskChukchi volcanic belt, in Bundtzen, T.K., Fonseca, A.L., and Mann, Roberta, eds., The Geology and Mineral Deposits of the Russian Far East: Alaska Miners Association, Glacier House Publications, Anchorage, Alaska, p. 134-140.

Grenda, Ondrej, and Trading, Lovinit, 1994, Slovakian magnesite-- Mining \& processing in Jelsava: Industrial Minerals, no. 324, p. 77-83.

Gross, G.A., 1996a, Lake Superior-type iron-formations, in Eckstrand, O.R., Sinclair, W.D., and Thorpe, R.I., eds., Geology of Canadian Mineral Deposit Types: Geological Survey of Canada, Geology of Canada, no. 8, p. 54-66.

Gross, G.A., 1996b, Mafic intrusion-hosted titanium-iron, in Eckstrand, O.R., Sinclair, W.D., and Thorpe, R.I., eds., Geology of Canadian Mineral Deposit Types: Geological Survey of Canada, Geology of Canada, no. 8, p. 573-582.

Harben, P.W., 2002, The industrial minerals handybook $-4^{\text {th }}$ Edition: A guide to markets, specifications and prices: Surrey, U.K., Industrial Minerals Information, 412 p.

Harben, P.W. and Kužvart, Mil•s, 1996, Industrial minerals: A global geology: London, Industrial Minerals Information Ltd., 462 p.

Harben, P.W., and Kuzvart, Milos, 1996, Industrial minerals-- A global geology: London, Industrial Minerals Information Ltd., 462 p.

Harries-Rees, Karen, 1992, Industrial minerals of the UK--keeping afloat: Industrial Minerals, no. 293, p. 21-37.

Hatjilazaridou, Kiki, Chalkiopoulou, Fotini, and Grossou-Valta, Martha, 1998, Greek industrial minerals-Current status and trends: Industrial Minerals, no. 369, p. 45-63.

Henriksen, N., Higgins, A.K., Kalsbeek, F., and Pulvertaft, T.C.R, 2000, Greenland from Archaean to Quaternary - Descriptive text to the geological map of Greenland: Geology of Greenland Survey Bulletin 185, 93 p. 1 sheet, scale: 1:2,500,000.

Herrington, R., ed., 2004, Major ore deposits of the Urals Mountains, in LODE: Largest ore deposits in Europe: http://www.gl.rhul.ac.uk/geode/dbase.html.

Hoffman, P.F., 1989, Precambrian geology and tectonic history of North America, in Bally, A.W. and Palmer, A.R., eds., The Geology of North America; An overview: Geological Society of America, The Geology of North America, volume A, p. 447-512.

Hruska, J., 1991, Czechoslovakia's minerals-- Production, reserves and exploration: Industrial Minerals, no. 289, p. 49-53.

Index mundi, 2004:

http://www.indexmundi.com/en/commodities/minerals/rare_earths/rare_earths_table06.html.

Industrial Minerals, 1992, no. 299, p. 15.

Industrial Minerals, 1997, no. 354, p. 16.

Industrial Minerals, 1999, no. 299, p. 15.

Industrial Minerals, 2002, Silver and Baryte buys Bentonit Hungaria, no. 412, p. 11-12.

Interfax Mining and Metals Report, 2004, Russia declassifies diamond production and trade statistics, v. 13, issue 51, p. 13-15.

Italpumice, S.p.A., 2004: http://www.italpomice.it/

Jakobsson, S.P., 1979, Outline of the petrology of Iceland: Jökull, v. 29, p. 57-73.

Jaskinia, Niedêwiedzia, 2004: www.showcaves.com/english/pl/showcaves/Niedzwiedzia.html. 
Jensen, S..M. and Secher, Karsten, 2004, Investigating the diamond potential of southern West Greenland: Geological Survey of Denmark and Greenland Bulletin 4, p. 69-72.

Johnson, Matthey, 2004, Platinum Today. Price Charts. ONLINE. Available: http://www.platinum.matthey.com/ prices/price_charts.html [January 31, 2004].

Karkanas, P., 1995, The slip-fiber chrysotile asbestos deposit in the Zidani area, northern Greece: Ore Geology Reviews, v. 10, p. 19-29.

Karlsen, T.A., 1998, Nordic minerals review-Norway: Industrial Minerals, no. 374, November, p. 73-76.

Kendall, Tom, 1994, Hungary's industrial minerals-Hostage to western fortunes: Industrial Minerals, no. 327, p. 19-33.

Khain, V.E., and Koronvosky, N.V., 1997, Caucasus Mountains, in Encyclopedia of European and Asian Regional Geology, Moores, E.M., and Fairbridge, RW., eds.: Chapman and Hall, New York, p. 127-136.

Khain, V.E., and Nikishin, A.M., 2001, Russia, in Rampino, M.R., ed., The Earth Sciences Encyclopedia Online (ESEO): SpringerLink Reference Works, (http://reference.kluweronline.com/?xmlid=6).

Kious, W.J and Tilling, R.I., 1996, This dynamic Earth: The story of plate tectonics. ONLINE version 1.0. Available: http://pubs.usgs.gov/publications/text/dynamic.html\#anchor19309449 [January 30, 2004]

Kirkham, R.V., 1995, Stratabound clastic-hosted uranium, lead, copper, in Eckstrand, O.R., Sinclair, W.D., and Thorp, R.I., Geology of Canadian mineral deposits, Geological Survey of Canada, Ottawa, 640 p.

Kirkham, R.V, Carriere, J.J., Laramee, R.M., and Garson, D.F., 1994, Global distribution of sediment-hosted stratiform copper deposits and occurrences: Geological Survey of Canada Open File 2915b, $256 \mathrm{p}$.

Kirkham, R.V., and Raefer, A.B., 2003, Selected world mineral deposits database: Geological Survey of Canada Open File 1801. [CD-ROM]

Kirkham R.V. and Sinclair W.D., 1996, Porphyry copper, gold, molybdenum, tungsten, tin, silver; in Eckstrand, O.R., Sinclair, W.D., and Thorpe, R.I., eds., Geology of Canadian Mineral Deposit Types: Geological Survey of Canada, Geology of Canada, no. 8, p. 421-446.

Kogarko, L.N., 1996, Geochemical models of supergiant apatite and rare metal deposits related to alkaline magmatism; Geochemistry International, v. 33, p. 129-149.

Koistinen, T., Stephens, M. B., Bogatchev, V., Nordgulen, O., Wennerstrom, M., and Korhonen, J., 2001, Map of the Fennoscandian Shield: Geological Surveys of Finland, Norway, Sweden, and Russia, 2 sheets, scale 1:2,000,000.

Korostylyov V.I., 1982, The geology and tectonics of the southern Verkhoyan area: Nauka, Novosibirsk, 217 p. (in Russian)

Krauss, U.H., Saam, H.G., and Schmidt, H.W., 1984, International Strategic Minerals Inventory summary report-Phosphate: U.S. Geological Survey Circular 930-C, 41 p.

Krauss, U.H., Schmidt, H.W., Taylor, H.A., Jr., and Sutphin, D.M., 1988, International Strategic Minerals Inventory summary report-Natural graphite: U.S. Geological Survey Circular 930-H, $29 \mathrm{p}$.

Kremenetsky, A., Lehmann, B, and Seltmann, R., eds., 2000, Ore-bearing granites of Russia and adjacent countries: IMGRE, Moscow, Russia, 371 p.

Kudryavtsev, Y.K., 1996, The copper-Mo deposits of central Kazakhstan, in Shatov, V., Seltmann, R., Kremenetsky, A., Lehmann, B., Popov, V., and Ermolov, P., eds., Granite-related Ore Deposits of Central Kazakhstan and Adjacent Areas, INTAS -93-1783 Project, Glagol Publishing House, St. Petersburg, p. 119-144. 
Kuo, C.S., 2002a, The mineral industries of Denmark, the Faroe Islands, and Greenland, 2002: U.S. Geological Survey Minerals Yearbook (Volume III. - Area Reports: International), http://minerals.usgs.gov/minerals/pubs/country/2002/damyb02.pdf.

Kuo, C.S., 2002b, The mineral industries of Estonia, Latvia, and Lithuania, 2002: U.S. Geological Survey Minerals Yearbook (Volume III. - Area Reports: International), http://minerals.usgs.gov/minerals/ pubs/country/2002/enlglhmyb02.pdf.

Kuo, C.S., 2002c, The mineral industry of Norway, 2002: U.S. Geological Survey Minerals Yearbook (Volume III. - Area Reports: International), http://minerals.usgs.gov/minerals/pubs/country/2002/nomyb02.pdf.

Kuo, C.S., 2002d, The mineral industry of Sweden, 2002: U.S. Geological Survey Minerals Yearbook (Volume III. - Area Reports: International), http://minerals.usgs.gov/minerals/pubs/country/2002/swmyb02r.pdf.

Kuo, C.S., 2003a, The mineral industry of Greenland, 2003: U.S. Geological Survey Minerals Yearbook (Volume III. - Area Reports: International), http://minerals.usgs.gov/minerals/pubs/country/2003/icmyb03.pdf.

Kuo, C.S., 2003b, The mineral industry of Iceland, 2003: U.S. Geological Survey Minerals Yearbook (Volume III. - Area Reports: International), http://minerals.usgs.gov/minerals/pubs/country/2003/icmyb03.pdf.

Kuzvart, M., 1981, Industrial minerals and rocks in Czechoslovakia: Industrial Minerals, no. 162, p. 19-35.

Larsen, S.M. and Secher, Karsten, 2004, Diamond exploration in Greenland: Geological Survey of Denmark and Greenland (GEUS) Exploration and Mining in Greenland Factsheet No. 7, 2 p.

Levine, R.M., Bendiner, M., and Wallace, G.J., 2002, The Minerals Industries of the Commonwealth of Independent States -- Armenia, Azerbaijan, Belarus, Georgia, Kazakhstan, Kyrgyzstan, Moldova, Russia, Tajikistan, Turkmenistan, Ukraine, and Uzbekistan - 2002: U.S. Geological Survey Minerals Yearbook (Volume III. - Area Reports: International), http://minerals.usgs.gov/minerals/pubs/country/2002/cismyb02.pdf.

Levine, R.M., Wallace, G.J., and Wilburn, D.R., 2001, The Mineral Industries of the Commonwealth of Independent States -- Armenia, Azerbaijan, Belarus, Georgia, Kazakhstan, Kyrgyzstan, Moldova, Russia, Tajikistan, Turkmenistan, Ukraine, and Uzbekistan - 2001: U.S. Geological Survey Minerals Yearbook (Volume III. - Area Reports: International), http://minerals.usgs.gov/minerals/pubs/country/2001/cismyb01.pdf.

Lode, Largest Ore Deposits in Europe, 2003, European Science Foundation, www.gl.rhbnc.ac.uk/geode/dbase.html.

Loughbrough, Roger, 1992, Italy's industrial minerals: A fistful of dollars: Industrial Minerals, no. 301, p. 35-57.

Loughbrough, Roger, 1993, Portugal's minerals: The next dimension: Industrial Minerals, no. 308, p. 47-67.

Luttig, G., 1990, Quaternary research in view of modern requirements of applied geology, in Kauranne, L.K., and Konigsson, L.K., eds., Economic Quaternary geology in the Nordic countries: 19th Uppsala symposium in Quaternary geology, Striae, v. 29, p.15-29.

Lydon, J.W., 1988, Volcanogenic massive sulphide deposits part 1: A descriptive model, in Roberts, R.G. and Sheahan, P.A., eds., Ore Deposit Models: Geoscience Canada Reprint Series 3, p. $145-153$.

Lydon, J.W., 1996, Sedimentary exhalative sulphides (sedex), in Eckstrand, O.R., Sinclair, W.D., and Thorpe, R.I., eds., Geology of Canadian Mineral Deposit Types: Geological Survey of Canada, Geology of Canada, no. 8, p. 130-152. 
Mariano, A.N., 1989, Nature of economic mineralization in carbonatites and related rocks, in Bell, Keith, ed., Carbonatites: genesis and evolution: Unwin Hyman, Boston, p. 149 - 176.

MBendi World: Mining, 2004, http://www.mbendi.co.za/indy/ming/p0005.htm

McFaul, E. J., Mason, G, Ferguson, W. B., and Lipin, B. R., 2000, U. S. Geological Survey Mineral Databases-MRDS and MAS/MILS: DDS-52, two CD's.

Mero, J.L., 1977, Economic aspects of nodule mining, in Glasby, G.P., ed., Marine manganese deposits: Amsterdam, Elsevier Scientific Publishing Company, p. 327-355.

Migineishvili, R., 2000, Formation of a volcanic-hosted massive sulfide deposit in a shallow water setting; the Madneuli $\mathrm{Cu}$-Au deposit, Georgia, in Volcanic environments and massive sulfide deposits; program and abstracts; international conference and field meeting, Gemmell, J.B., and Pongratz, June, eds: Special Publication - Centre for Ore Deposit and Exploration Studies (CODES), v. 3, p. 123-125.

Mindat, 2004: www.mindat.org/index.php.

Mineral Resources of Georgia, 2004: http://www.mineralresources.ge.

Mining and Metals Company - Norilsk Nickel Annual Report, 2003:

http://www.nornik.ru/en/shareholders/ annual_reports/

Mining Journal, 2000, Greenland: Supplement to the Mining Journal, February, 2000, 16 p.

Mining Technology, 2004: http://www.mining-technology.com/projects/boulby/index.html.

Mitchell, R.H., 1986, Kimberlites: mineralogy, geochemistry, and petrology: Plenum Press, New York, $442 \mathrm{p}$.

Mitchell, R.H., 1993, Kimberlites and lamproites: primary sources of diamond, in Sheahan, P.A. and Cherry, M.E., eds., Ore deposit models, volume II: Geoscience Canada Reprint Series 6, p. 13-28.

Molnar, Jozsef, 1989, Perlite mining in Hungary: Mining Magazine, v. 161, no. 6, p. 498-501.

Moores, E.M., and Fairbridge, R.W., eds., 1997, Encyclopedia of European and Asian Regional Geology, Chapman and Hall, New York.

Mukhin, P., 1997, Uzbekistan, in, Moores, E.M., and Fairbridge, RW, eds., Encyclopedia of European and Asian Regional Geology: Chapman and Hall, New York, p. 766-773.

Natapov, L.M., Egorov, A.Yu., Rodnov Yu.N., and Belkina, I.L., 2000, in Rundkvist D.V., ed., Mineragenic map of Russia and adjacent territories: AEROGEOLOGIA, Moscow, 16 sheets, scale 1:2,500,000, 1 CD-ROM, 49 p.

Newman, H.R., 2001a, The mineral industry of Germany - 2001: U.S. Geological Survey Minerals Yearbook (Volume III. - Area Reports: International), http://minerals.usgs.gov/minerals/pubs/ country/2001/gmmyb01.pdf.

Newman, H.R., 2001b, The mineral industry of Italy - 2001: U.S. Geological Survey Minerals Yearbook (Volume III. - Area Reports: International), http://minerals.usgs.gov/minerals/ pubs/country/2001/itmyb01.pdf.

Newman, H.R., 2002a, The mineral industry of Belgium and Luxembourg - 2002: U.S. Geological Survey Minerals Yearbook (Volume III. - Area Reports: International), http://minerals.usgs.gov/minerals/pubs/ country/2002/belumyb02.pdf.

Newman, H.R., 2002b, The mineral industry of Greece - 2002: U.S. Geological Survey Minerals Yearbook (Volume III. - Area Reports: International), http://minerals.usgs.gov/minerals/pubs/ country/2002/grmyb02.pdf.

Newman, H.R., 2002c, The mineral industry of France - 2002: U.S. Geological Survey Minerals Yearbook (Volume III. - Area Reports: International), http://minerals.usgs.gov/minerals/pubs/ country/2002/frmyb02.pdf. 
Newman, H.R., 2002d, The mineral industry of Ireland - 2002: U.S. Geological Survey Minerals Yearbook (Volume III. - Area Reports: International), http://minerals.usgs.gov/minerals/pubs/ country/2002/eimyb02.pdf.

Newman, H.R., 2002e, The mineral industry of the Netherlands - 2002: U.S. Geological Survey Minerals Yearbook (Volume III. - Area Reports: International), http://minerals.usgs.gov/minerals/pubs/ country/2002/nlmyb02.pdf.

Newman, H.R., 2002f, The mineral industry of Portugal - 2002: U.S. Geological Survey Minerals Yearbook (Volume III. - Area Reports: International), http://minerals.usgs.gov/minerals/pubs/ country/2002/pomyb02.pdf.

Newman, H.R., 2002g, The mineral industry of Spain - 2002: U.S. Geological Survey Minerals Yearbook (Volume III. - Area Reports: International), http://minerals.usgs.gov/minerals/pubs/ country/2002/spmyb02.pdf.

Newman, H.R., 2002h, The mineral industry of the United Kingdom - 2002: U.S. Geological Survey Minerals Yearbook (Volume III. - Area Reports: International), http://minerals.usgs.gov/minerals/pubs/country/2002/ ukmyb02.pdf.

Newman, H.R., 2003a, The mineral industry of Austria - 2003: U.S. Geological Survey Minerals Yearbook (Volume III. - Area Reports: International http://minerals.usgs.gov/minerals/pubs/country/2003/aumyb03.pdf

Newman, H.R., 2003b, The mineral industry of Malta - 2003: U.S. Geological Survey Minerals Yearbook (Volume III. - Area Reports: International), http://minerals.usgs.gov/minerals/pubs/ country/2003/mtmyb03.pdf.

Newman, H.R., 2003b, The mineral industry of Switzerland - 2003: U.S. Geological Survey Minerals Yearbook (Volume III. - Area Reports: International), http://minerals.usgs.gov/minerals/pubs/ country/2003/szmyb03.pdf.

Nielsen, B.L, 1976, Economic minerals, in Escher, Arthur and Watt, W.S., eds., Geology of Greenland: Copenhagen, Denmark, The Geological Society of Greenland, p. 460-487.

Nielsen, T.F.D., 2001, The palladium potential of the Skaergaard Intrusion, south-east Greenland: Danmarks og Grønlands Geologiske Undersøgelse Rapport 2001/23, 39 p.

Nokleberg, W.J., Bundtzen, T.K., Dawson, K.M., Eremin, R.A., Goryachev, N.A., Koch, R.D. Ratkin, V.V., Rozenblum, I.S., Shpikerman, V.I., Frolov, Y.F., Gorodinsky, M.E., Melnikov, V.D., Diggles, M.F., Ognyanov, N.V., Petrachenko, E.D., Petrachenko, R.I., Pozdeev, A.I., Ross, K.V., Wood, D.H., Grybeck, Donald, Khanchuk, A.I., Kovbas, L.I., Nekrasov, I.Ya., and Sidorov, A.A., 1997, Significant metalliferous lode deposits and placer districts for the Russian Far East, Alaska, and the Canadian Cordillera: U.S. Geological Survey Open-File Report 96-513$\mathrm{B}, 1 \mathrm{CD}$.

Nokleberg, W.J., Bundtzen, T.K., Eremin, R.A., Ratkin, V.V., Dawson, KM., Shpikerman, V.I., Goryachev, N.A., Byalobzhesky, S.G., Frolov, Y.F., Khanchuk, A.I., Koch, R.D., Monger, J.W.H., Pozdeev, A.I., Rozenblum, I.S., Rodionov, S.M., Parfenov, L.M., Scotese, C.R., and Sidorov, A.A., 2003 Metallogenesis and Tectonics of the Russian Far East, Alaska, and the Canadian Cordillera:: U.S. Geological Survey Open File Report 03-434, 406 p.

Nokleberg, W.J., Parfenov, L.M., Monger, J.W.H., Norton, I.O., Khanchuk, A.I., Stone, D.B., Scotese, C.R., Scholl, D.W., and Fujita, K., 2001, Phanerozoic Tectonic Evolution of the CircumNorth Pacific: U.S. Geological Survey Professional Paper 1626, 126 p.

Nokleberg, W.J., Parfenov, L.M., and Monger, J.W.H., and Baranov, B.V., Byalobzhesky, S.G., Bundtzen, T.K., Feeney, T.D., Fujita, Kazuya, Gordey, S.P., Grantz, Arthur, Khanchuk, A.I., Natal'in, B.A., Natapov, L.M., Norton, I.O., Patton, W.W., Jr., Plafker, George, Scholl, D.W., Sokolov, S.D., Sosunov, G.M., Stone, D.B., Tabor, R.W., Tsukanov, N.V., Vallier, T.L. and 
Wakita, Koji, 1994, Circum-North Pacific tectono-stratigraphic terrane map: U.S. Geological

Survey Open-File Report 94-714, 2 sheets, scale 1:5,000,000; 2 sheets, scale 1:10,000,000, 211 p.

Nokleberg, W.J., Parfenov, L.M., and Monger, J.W.H., and Baranov, B.V., Byalobzhesky, S.G., Bundtzen, T.K., Feeney, T.D., Fujita, Kazuya, Gordey, S.P., Grantz, Arthur, Khanchuk, A.I., Natal'in, B.A., Natapov, L.M., Norton, I.O., Patton, W.W., Jr., Plafker, George, Scholl, D.W., Sokolov, S.D., Sosunov, G.M., Stone, D.B., Tabor, R.W., Tsukanov, N.V., and Vallier, T.L., 1997, Summary Circum-North Pacific tectono-stratigraphic terrane map: U.S. Geological Survey Open-File Report 96-727, scale 1:10,000,000.

Northern Miner, 1997, First Dynasty Joins JV in Armenia, v. 82, no. 50, p. 55-62.

Notholt, Arthur, 1991, Mining in central Europe: Mining Magazine, v. 164, no. 4, p. 198-202.

O'Driscoll, Mike, 1998, Ukraine's minerals-First steppes in world market: Industrial Minerals, no. 373 , p. 21-43.

Olerud, Svein, 1993, Norway's industrial minerals-- Production \& development trends: Industrial Minerals, no. 307, p. 55-63.

Parfenov, L.M., Khanchuk, A.I., Badarch, Gombosuren, Miller, R.J., Naumova, V.V., Nokleberg, W.J., Ogasawara, Masatsugu, Prokopiev, A.V., Yan, Hongquan, Belichenko, Valentina, Berzin, N.A., Bulgatov, A.N., Byamba, Jamba, Deikunenko, A.V., Dong, Yongsheng, Dril, S.O., Gordienko, I.V., Hwang, Duk Hwan, Kim, B.I., Korago. E.A., Kos'ko, M.K., Kuzmin, M.I., Orolmaa, Demberel, Oxman, V.S., Popeko, L.I., Rudnev, S.N., Sklyarov, E.V., Smelov, A.P., Sudo, Sadahisa, Suprunenko, O.I., Sun, Jiapeng, Timofeev, V.F., Tret'yakov, F.F., Tomurtogoo, Onongin, Vernikovsky, V.A., Vladimiro, A.G., Wakita, Koji, Ye, Mao, and Zedgenizov, A.N., 2003, Preliminary Northeast Asia Geodynamics Map: U.S. Geological Survey Open-File Report 03-205, 2 sheets, scale 1:5,000,000.

Parfenov, L.M., Khanchuk, A.I., Badarch, G., Berzin, N.A., Miller, R.J., Naumova, V.V., Nokleberg, W.J., Ogasawara, M., Prokopiev, A.V., and Yan, H., 2004, Descriptions of overlap assemblages and tectono-stratigraphic terranes, definitions, and methods for compilation for Northeast Asia geodynamics map, in Nokleberg, W.J., Badarch, Gombosuren, Berzin, N.A., Diggles, M.F., Hwang, Duk Hwan, Khanchuk, A.I., Miller, R.J. Naumova, V.V., Obolenskiy, A.A., Ogasawara, Masatsugu, Parfenov, L.M., Prokopiev. A.V., Rodionov, S.M., and Hongquan, Yan, 2004: U.S.G.S. Open-File Report 2004-1252 (CD-ROM).

Pearse, G., 2000, Potash, in Canadian Minerals Yearbook: http://www.nrcan.gc.ca/mms/cmy/content/2000/46.pdf.

Rastsvetaev, L., 1997, Turkmenistan, in Encyclopedia of European and Asian Regional Geology, Moores, E.M., and Fairbridge, RW, eds., Chapman and Hall, New York, p. 743-759.

Regueiro y González-Barros, Manuel, 1995, Spanish industrial minerals and rocks--industries come of age: Industrial Minerals, no. 332, p. 63-77.

Robbins, Jacqui, 1985, The industrial minerals of West Germany: Industrial Minerals, no. 219, p. 15-47.

Robert, Francois, 1996, Quartz-carbonate vein gold, in Eckstrand, O.R., Sinclair, W.D., and Thorpe, R.I., eds., Geology of Canadian Mineral Deposit Types: Geological Survey of Canada, Geology of Canada, no. 8, p. 350-366.

Roberts, R.G., 1988, Archean lode gold deposits, in Roberts, R.G, and Sheahan, P.A. eds., Ore deposit models: Geoscience Canada Reprint Series 3, p. 1-20.

Roskill Information Services, 1983, The economics of salt, $4^{\text {th }}$ ed.: London, Roskill Information Services, $306 \mathrm{p}$.

Roskill Information Services, 1989, The economics of potash: London, England, 205 p. 
Safonov, Ju, G., 1997, Hydrothermal gold-ore deposits: Distribution, geological and genetical types, and productivity of ore-forming systems: Geology of Ore Deposits, v. 39, no. 1, p. 25-40 (in Russian).

Sangster, D. F., 1996a, Mississippi Valley-type lead and zinc, in Eckstrand, O.R., Sinclair, W.D., and Thorpe, R.I., eds., Geology of Canadian Mineral Deposit Types: Geological Survey of Canada, Geology of Canada, no. 8, p. 253-261.

Sangster, D.F., ed., 1996b, Carbnonate hosted lead and zinc deposits: Society of Economic Geologist Special Publication Number 4.

Schjøth, Frands, Garde, A.A., Jørgensen, M.S., Lind, Mogens, Moberg, Else, Nielsen, T.F.D., Rasmussen, T.M., Secher, Karsten, Steenfelt, Agnete, Stendal, Henrik, Thorning, Leif, and Tukiainen, Tapani, 2000, Mineral resource potential of south Greenland: the CD-ROM: Danmarks og Grønlands Geologiske Undersøgelse Rapport 2000/57, CD-ROM, 37 p.

Saemundsson, K., 1979, Outline of the geology of Iceland: Jökull, v. 29, p. 7-28.

Schwan, W., 1997, Europe, in Moores, E.M>, and Fairbridge, R.W., eds., Encyclopedia of European and Asian Regional Geology: Chapman and Hall, New York, p. 201-227.

Schwan, W., 2001, Europe, in Rampino, M.R., ed., The Earth Sciences Encyclopedia Online (ESEO): SpringerLink Reference Works, (http://reference.kluweronline.com/?xmlid=6).

Seacology, 2004: www.seacology.org/index.cfm.

Secher, K., 2002, Deposits of specialty metals in south Greenland: Geological Survey of Denmark and Greenland (GEUS) Greenland Mineral Resources Fact Sheet No. 3, 2 p.

Seltmann, R, and Jenchuraeva, R., eds., 2001, Paleozoic geodynamics and gold deposits in the Kyrgyz Tien Shan, Excursion Guidebook, IGCP-373 Field Conference, Bishkek and the Kyrgyz Tien Shan, 16-25 August, 2001, and Pre-meerting Field Trip A5 of the Joint 6th Biennial SGASEG Meeting, Krakow, Poland, 180 p.

Seltmann, R., Shatov, V., and Yakubchuk, A., eds., 2003, Central Asia AV 3.2 GIS package: database and mineral deposits map: International Geological Correlation Program, IGCP Project 473 "GIS metallogeny of Central Asia" publication, London, England, 1 sheet, scale 1,500,000. engör, A.M.C., and Natal'in BA, 1996, Paleotectonics of Asia: fragments and synthesis, in Yin, A., and Harrison, M., eds., The tectonic evolution of Asia, Cambridge University Press, p. 486640.

Shayakubov, T, Islamov, F, Kremenetsky, A, and Seltmann, R., eds., 1999, Au, Ag, and Cu deposits of Uzbekistan, International field conference of IGCP-373, Excursion B6 of the Joint SGA-IAGOD symposium, London- Tashkent, 27 August - 4 September, 1999, 112 p.

Sherlock, Ross, and Logan, A.V., eds., 2000, VMS deposits of Latin America: Newfoundland, Canada, Geological Association of Canada, $641 \mathrm{p}$.

Shpikerman V.I., 1998, Pre-Cretaceous metallogeny of Northeastern Asia: Russian Academy of Sciences, Northeastern Interdisciplinary Research Institute, Magadan, 333 p. (in Russian). Shkolnik, E.L., Gvozdev, V.I., Malinko, S.V., Punina, T.A., Slukin, A.D., and Ignatyev, A.V., 2003, The origin of borosilicate mineralization of Dalnegorsk deposit, Primorye Territory, Russia: Geology of the Pacific Ocean, v. 22, no. 3, p. 122-134. (in Russian).

Sillitoe, R.H., 1998, Discovery of major ore deposits in the Circum-pacific region: the past is the key to the future, in Walton, Godfrey, and Jambor, John, eds., Pathways '98 Extended abstracts volume: Society of Economic Geologists, p. 94-96.

Singer, D.A., 1995, World class base and precious metal deposits - a quantitative analysis: Economic Geology v. 90, p. 88-104.

Singer, D.A., Berger, V.I., and Moring, B.C., 2002, Porphyry copper deposits of the world: database, maps, and preliminary analysis: U.S. Geological Survey Open-File Report 02-268, http://geopubs.wr.usgs.gov/open-file/of02-268/ 
Skanska, 2004: http://www.skanska.com/.

Smirnov, V.I., ed., 1978, Mineral Deposits of the U.S.S.R., Second edition, v. 2: Nedra, Moscow, 399 p. (in Russian).

Steblez, W.G., 2001, The mineral industry of the Adriatic Balkans (Albania, Boxnia and Herzegovina, Croatia, Macedonia, Serbia and Montenegro, and Slovenia) - 2001: U.S. Geological Survey Minerals Yearbook (Volume III. - Area Reports: International), http://minerals.usgs.gov/minerals/pubs/ country/2001/albkhrmkmyb01.pdf.

Steblez, W.G., 2001b, The mineral industries of Bulgaria and Romania - 2001: U.S. Geological Survey Minerals Yearbook (Volume III. - Area Reports: International), http://minerals.usgs.gov/minerals/pubs/country/2001/buromyb01.pdf.

Steblez, W.G., 2001c, The mineral industries of the Czech Republic, Hungary, Poland, and Slovakia - 2001: http://minerals.usgs.gov/minerals/pubs/country/2001/ezhupllomyb01.pdf.

Steblez, W.G., 2002, The mineral industries of Ireland - 2002: U.S. Geological Survey Minerals Yearbook (Volume III. - Area Reports: International), http://minerals.usgs.gov/minerals/pubs/ country/2002/eimyb02.pdf.

Steblez, W.G., Kuo, C.S., Levine, R.M., Newman, H.R., and Wilburn, D.R., 2001, The mineral industries of Europe and central Asia - 2001: U.S. Geological Survey Minerals Yearbook (Volume III. - Area Reports: International), http://minerals.usgs.gov/minerals/pubs/country/2001/europe01.pdf.

Stemmerik, Lars, Clausen, O.R., KorstgÃ¥rd, John, Larsen, Michael, Piasecki, Stefan, Seidler, Lars, Surlyk, Finn and Therkelsen, Jens, 1997, Petroleum geological investigations in East Greenland project on resources of the sedimentary basins of North and East Greenland: Geology of Greenland Survey Bulletin 176, p. 29-38.

Stendal, Henrik and Secher, Karsten, 2002, Gold mineralization and gold potential in South Greenland: Geological Survey of Denmark and Greenland (GEUS) Exploration and Mining in Greenland Geology and Ore No. 1, 12 p.

Stendel, H. and Secher, K., 2002, Gold mineralization and gold potential in south Greenland: Geological Survey of Denmark and Greenland (GEUS) Greenland Mineral Resources Fact Sheet No. 1,2 p.

Steinthorsson, S., and Thorarinsson, S., 2001, Iceland, in Rampino, M.R., ed., The Earth Sciences Encyclopedia Online (ESEO): SpringerLink Reference Works, (http://reference.kluweronline.com/?xmlid=6).

Sutphin, D.M., Sabin, A.E., and Reed, B.L., 1990, International strategic minerals inventory summary report - Tin: U.S. Geological Survey Circular 930-J, 52 p.

Thompson, T.B., 2002, Geology of Carlin-type gold deposits: insights from the Great Basin deposits, Nevada: in Cooke, D.R., and Pongratz, June, eds., Giant ore deposits: characteristics, genesis and exploration, Centre for Ore Deposit Research, University of Tasmania, GPO Box 252-79, Hobart, Tasmania, Australia 7001, p. 161-174

Thomassen, Bjørn, 2003, The Black Angel lead and zinc mine at Maarmorilik in west Greenland: Geological Survey of Denmark and Greenland (GEUS) Geology and Ore No. 2, 12 p.

Towner, R.R., Gray. J.M., and Porter, L.M., 1988, International strategic minerals inventory summary report - titanium: U. S. Geological Survey Open-File Report 930-G, 58 p.

Trendall, A.F., 2002, The significance of iron-formation in the Precambrian stratigraphic record: Special Publications of the International Association of Sedimentologists, v. 33, p. 33-66.

Triller, E. and Lauenstein, 1987, World mining map of copper, lead, zinc, tin, nickel, and aluminum: Metallgesellschaft AG, Frankfurt, 1 sheet, scale 1:27,500,000. 
Troitsky, Vladimir, Petrov, Igor, and Grishaev, Sergey, 1998, in Industrial Minerals of the CIS, Kendall, Tom, and Keegan, Nina, eds.: Industrial Minerals Information Ltd., Worcester Park, England, $135 \mathrm{p}$.

U.S. Geological Survey, 1997, GTOPO30 Global 30 Arc Second Elevation Data Set, available at http://edcwww.cr.usgs.gov/landdaac/gtopo30/gtopo30.html

U.S. Geological Survey, 2003, Mineral commodity summaries 2003: U.S. Geological Survey, Mineral Commodity Summaries, 199 p. Available: http://minerals.usgs.gov/minerals/pubs/mcs/2003/mcs2003.pdf.

U.S. Geological Survey, 2004, Mineral commodity summaries 2004: U.S. Government Printing Office, Washington, D.C., 197 p. Available: http://minerals.usgs.gov/minerals/pubs/mcs/2004/mcs2004.pdf.

U.S. Geological Survey, 2005, Mineral commodity summaries 2005: U.S. Government Printing Office, Washington, D.C., 199 p. Available: http://minerals.usgs.gov/minerals/pubs/mcs/2005/mcs2005.pdf.

Van der Stijl, F.W. and Mosher, G.Z., 1998, The Citronen Fjord massive sulphide deposit, Peary Land, North Greenland: discovery, stratigraphy, mineralization and structural setting: Geology of Greenland Survey Bulletin 179, 40 pp.

Vázquez-Guzmán, F., 1989, Spain, in Mineral Deposits of Europe, Southwest and Eastern Europe, with Iceland, Dunning, F.W., Garrard, P., Haslam, H.W., and Ixer, R.A., eds.: The Institution of Mining and Metallurgy and The Mineralogical Society, London, p. 105-196.

Werner, A. B.T., Sinclair, W.D., and Amey, E.B., 1998, International Strategic Mineral Issues summary report-Tungsten: U. S. Geological Survey Circular 930-O, 71 p.

White, N.C., Hedenquist, J.W., and Kirkham, R.V., 2001, Asia: The waking giant: Mining Journal supplement, March 2001, 12 p.

Wikk, Nils-Gunnar, 1996, Industrial minerals and rocks in Sweden: Industrial Minerals, no. 340, p. 41-49.

Wilburn, D.R., 2004, Nonfuel mineral exploration 2003: Mining Engineering, v. 56, no. 5, p. $25-$ 37.

Wiltshire, John, 2001, Future prospects for the marine minerals industry: UnderWater Magazine Article reprint, May/June 2001, publically available on the web on 6/30/04, at: http://www.diveweb.com/offshore/features/ mayjun2001.02.htm, 6 p.

Windley, B.F., 1977, The evolving continents: New York, John Wiley and Sons, 385 p.

Woolley, A.R., 1987, Alkaline rocks and carbonatites of the world. Part 1: North and South America: University of Texas Press, Austin, Texas, 216 p.

Woolley, A.R., 1989, The spatial and temporal distribution of carbonatites, in Bell, Keith, ed., Carbonatites: genesis and evolution: Unwin Hyman, Boston, p. 15 - 37.

Yakubchuk, A, 1997, Kazakhstan, in Encyclopedia of European and Asian Regional Geology, Moores, E.M., and Fairbridge, RW, eds., Chapman and Hall, New York, p. 450-465.

Yakubchuk, A., Cole, A., Seltmann, R., and Shatov, V.V., 2002, Tectonic setting, characteristics, and regional exploration criteria for gold mineralization in Central Asia: The southern Tien Shan province as a key example, in Goldfarb, R.J., and Nielsen, R.L., eds., Integrated Methods for Discovery: Global Exploration in the Twenty-First Centurey, Society of Economic Geologists Special Publication 9, p. 177-201.

Yakubchuk, A., Seltmann. R., Shatov, V.V., and Cole,A., 2001, The Altay Mountains: tectonic evolution and metallogeny: Society of Economic Geologists Newsletter, v. 46, p. 1, 7-14.

Yeats, C.J. and Vanderhor, Fop, 1998, Archean lode-gold deposits: Journal of Australian Geology and Geophysics v. 17, no. 4, p. 253-258. 
Ziegler, P.A., 1990, Geological atlas of western and central Europe, 2nd ed.: Shell Internationale Petroleum, Maatschappij, Hague, 239 p.

Zinc deposits in Finland, 2004: http://www.gsf.fi/explor/zinc/gtk_zinc_map.htm.

Zonenshain, L.P., Korinevski, V.G., Kazmin, V.G., Perchersky, D.M., and Khain, V.V., 1984, Plate tectonic model of the South Urals development: Tectonophysics, v. 109, p. 95-135.

Zonenshain, L.P., Kuzmin, M.I., and Natapov, L.M., 1990, Geology of the USSR: A plate-tectonic synthesis: American Geophysical Union Geodyamics Series, v. 21, 242 p. 


\section{Tables}

Table 1. Principal nonfuel mineral commodities that have been historically mined in Greenland, Europe, Russia, and Northern Central Asia. Adapted from U.S. Geological Survey Minerals Yearbook, v. III. - Area Reports: International, U.S. Geological Survey (2002), U.S. Geological Survey (2004), and from Table 2 (this report). Commodities in bold are major current world producers according to the U.S. Geological Survey (2004). Aggregate (sand and gravel) is not included.

\begin{tabular}{|c|c|}
\hline Country & Mineral Commodities \\
\hline Albania & chromite, copper, dolomite, gypsum, marble, nickel \\
\hline Andora & iron ore, lead \\
\hline Armenia & bauxite, copper, gold, lead, molybdenum, perlite, silver, zinc \\
\hline Austria & $\begin{array}{l}\text { anhydrite, copper, dimension stone, graphite, gypsum, illite, iron ore, kaolinite, lead, limestone } \\
\text { (lime), magnesite, magnesium, salt, talc,tungsten }\end{array}$ \\
\hline Azerbaijan & $\begin{array}{l}\text { bauxite, alunite, barite, bentonite, cobalt, copper, dimension stone, gold, iron ore, lead, limestone } \\
\text { (lime), mercury, molybdenum, salt, silver, zinc }\end{array}$ \\
\hline Belarus & chalk, clay, granite, limestone, potash \\
\hline Belgium & cadmium, dolomite, indium, limestone, marble, silica sand \\
\hline Bosnia and Herzegovina & bauxite, barite, bauxite, copper, gypsum, iron ore, lead, manganese, salt, zinc \\
\hline Bulgaria & $\begin{array}{l}\text { barite, clay, copper, gold, dimension stone, gypsum, iron ore, lead, limestone (lime), manganese, } \\
\text { rock salt, silica, silver, zinc }\end{array}$ \\
\hline Croatia & bauxite, clay, iron ore, silica \\
\hline Cyprus & asbestos, clay, copper, gypsum, marble, salt \\
\hline Czech Republic & clay, bentonite, diatomite, feldspar, gem pyrope, graphite, gypsum, kaolin, iron ore \\
\hline Denmark & diatomite, dimension stone, limestone, phosphate, salt \\
\hline Estonia & clay, silica sand \\
\hline Finland & $\begin{array}{l}\text { chromium, copper, gold, iron ore, limestone, platinum-group metals, nickel, phosphate, silver, } \\
\text { sulfur, talc, titanium, zinc }\end{array}$ \\
\hline France & $\begin{array}{l}\text { bauxitef, barite, bromine, diatomite, dimension stone, feldspar, fluorspar, gypsum, indium, iron } \\
\text { ore, kyanite, limestone (lime), potash, mica, pumice, salt, silicon, sulfur, talc, zinc }\end{array}$ \\
\hline Georgia & copper, gold, iron ore, manganese \\
\hline Germany & $\begin{array}{l}\text { barite, bromine, cadmium, copper, feldspar, gypsum, iron ore, kaolin, lead, limestone (lime), } \\
\text { nickel, potash, pumice, salt, sulfur, zinc }\end{array}$ \\
\hline Greece & $\begin{array}{l}\text { bauxite, bentonite, cobalt, copper, gold, gypsum, dimension stone, feldspar, kaolin, lead, } \\
\text { magnesium, nickel, marble, perlite, pumice, zeolite, zinc }\end{array}$ \\
\hline Greenland & cryolite, graphite, lead, silver, gold, zinc \\
\hline Holy See (Vatican City) & not applicable \\
\hline Hungary & bauxite, bentonite, copper, kaolin, lead, limestone, manganese, perlite, zinc \\
\hline Iceland & diatomite, silicon \\
\hline Ireland & barite, copper, gypsum, lead, limestone, silver, zinc \\
\hline Italy & $\begin{array}{l}\text { bauxite, asbestos, barite, bromine, clay, dimension sonte, feldspar, fluorspar, gold, gypsum, lead, } \\
\text { limestone (lime), marble, mercury, pumice, salt, silver, sulfur, titanium, zinc }\end{array}$ \\
\hline Kazakhstan & $\begin{array}{l}\text { bauxite, asbestos, bismuth, cadmium, chromium, cobalt, copper, gold, iron ore, lead, } \\
\text { manganese, molybdenum, nickel, silicon, sulfur, zinc }\end{array}$ \\
\hline Kyrgyzstan & bismuth, gold, lead, mercury, molybdenum, tin, rare-earth metals, zinc \\
\hline Latvia & amber, clay, gypsum, limestone (lime) \\
\hline Liechtenstein & not applicable \\
\hline Lithuania & clay, limestone \\
\hline
\end{tabular}




\begin{tabular}{|c|c|}
\hline Luxembourg & dolomite, limestone, sand ,gravel, and slate \\
\hline Macedonia & $\begin{array}{l}\text { asbestos, bentonite, chromium, dimension stone, copper, feldspar, gold, gypsum, iron ore, lead, } \\
\text { limestone (lime), manganese, nickel, zinc }\end{array}$ \\
\hline Malta & limestone, salt \\
\hline Macedonia & $\begin{array}{l}\text { bentonite, copper, chromium, dimension stone, feldspar, gold, gypsum, iron ore, lead, limestone } \\
\text { (lime), manganese, nickel, zinc }\end{array}$ \\
\hline Moldova & gypsum, limestone (lime) \\
\hline Monaco & not applicable \\
\hline Netherlands & limestone, manganese, peat, potash, salt, sulfur, salt \\
\hline Norway & copper, feldspar, graphite, limestone, iron ore, nickel, PGE, silicon, talc, titanium \\
\hline Poland & $\begin{array}{l}\text { amber, cadmium, ceramic clay, copper, feldspar, gypsum, gold, kaolin, lead, limestone (lime), } \\
\text { magnesium, salt, silicon, silver, sulfur, zinc }\end{array}$ \\
\hline Portugal & copper, dimension stone, iron ore, limestone (lime), lithium, marble, pyrite, tin, tungsten \\
\hline Romania & $\begin{array}{l}\text { bauxite, antimony, bismuth, cadium, clay, copper, feldspar, gold, graphite, gypsum, iron ore, lead, } \\
\text { limestone, manganese, mica, salt, silicon, silver, titanium, zinc }\end{array}$ \\
\hline Russia & $\begin{array}{l}\text { bauxite, amber, antimony, arsenic, asbestos, barite, boron, bentonite (includes other CIS } \\
\text { countries), cadmium, cobalt, chromium, copper, diamond, diatomite, fluorspar, gemstones, } \\
\text { gold, graphite, indium, iodine, iron ore, lead, limestone (lime), magnesium, mica (sheet), } \\
\text { mercury, molybdenum, nickel, phosphate, platinum-group metals, potash, rare-earth metals, } \\
\text { salt, silver, silicon, sulfur, tin, tungsten, vanadium, zinc }\end{array}$ \\
\hline San Marino & not applicable \\
\hline Serbia and Montenegro & bauxite, copper, gold, kaolin, lead, limestone, magnesium, marble, nickel, quartz, zinc \\
\hline Slovakia & bauxite, barite, clay, copper, gold, iron ore, magnesium, manganese, perlite, salt, silicon \\
\hline Slovenia & copper, iron ore, gold, lead, mercury, zinc \\
\hline Spain & $\begin{array}{l}\text { bauxite, copper, diatomite, dimension stone, feldspar, fluorspar, gold, gypsum, ilmenite, iron } \\
\text { ore, kaolin, kyanite, lead, limestone (lime), magnesium, mica, mercury,mica, potash, pumice, } \\
\text { salt, silicon, silver, strontium, sulfur, tungsten, zinc }\end{array}$ \\
\hline Sweden & copper, feldspar, gold, graphite, lead, iron ore, marble, silver, zinc \\
\hline Switzerland & limestone (lime), gypsum, salt \\
\hline Tajikistan & $\begin{array}{l}\text { antimony, dolomite, gold, gem minerals, lead, limestone (lime), marble, salt, silver, strontium, } \\
\text { tungsten, zinc }\end{array}$ \\
\hline Turkmenistan & barium, bromine, clay, iodine, limestone (lime), potash, quartz sand, salt, sodium sulfate, sulfur \\
\hline Ukraine & $\begin{array}{l}\text { bromine, cadmium, dolomite, germanium, graphite, kaolin, ilmenite, iron ore, kaolin, limestone, } \\
\text { magnesium, manganese, mercury, nickel, potash, quartz, rutile, salt, silicon, sulfur, uranium, } \\
\text { zircon }\end{array}$ \\
\hline United Kingdom & $\begin{array}{l}\text { barite, bentonite, bromine, chalk, clay, fluorspar, gypsum, halite, ilmenite, kaolin, limestone, } \\
\text { potash, salt, tungsten, tin }\end{array}$ \\
\hline Uzbekistan & $\begin{array}{l}\text { copper, feldspar, gold, lead, manganese, molybdenum, potash, rare-earth elements, silver, } \\
\text { tungsten, zinc }\end{array}$ \\
\hline
\end{tabular}


Table 2A. Mineral deposit name, location, principal commodities, type, and reference for the major metallic mineral deposits in Greenland, Europe, Russia, and Northern Central Asia. Table includes some duplications because of variable transliteration methods. Transliterations of names according to source reference.

\begin{tabular}{|c|c|c|c|c|c|c|}
\hline Deposit Name & Country & Latitude & Longitude & Commodities & Deposit Type & Reference \\
\hline Bulqiza & Albania & $4131 \mathrm{~N}$ & $2016 \mathrm{E}$ & Chromium & Igneous & Lode, 2003. \\
\hline Gjegjan & Albania & $4210 \mathrm{~N}$ & $19056 \mathrm{E}$ & Copper & Hydrothermal & Triller and Lauenstein, 1987. \\
\hline Guri Kuq/Prrenjas & Albania & $4114 \mathrm{~N}$ & $2016 \mathrm{E}$ & Nickel, Cobalt, Iron & Surficial & DeYoung and others, 1985. \\
\hline Amasijskoe & Armenia & $40525 \mathrm{~N}$ & $434559 \mathrm{E}$ & Antimony & Hydrothermal & Natapov and others, 2000. \\
\hline Kadzharanskoe & Armenia & $391011 \mathrm{~N}$ & $46517 \mathrm{E}$ & Copper, Molybdenum & Igneous & Singer and others, 2002. \\
\hline Privol'nenskoe & Armenia & $41830 \mathrm{~N}$ & $442248 \mathrm{E}$ & Lead, Zinc & Hydrothermal & Natapov and others, 2000 \\
\hline Zod & Armenia & $4013 \mathrm{~N}$ & $4556 \mathrm{E}$ & Gold & Hydrothermal & Northern Miner, 1997. \\
\hline Bleiberg & Austria & $4638 \mathrm{~N}$ & $1449 \mathrm{E}$ & Zinc, Lead & Sedimentary & McFaul and others, 2000. \\
\hline Doppl-Muehldorf-Zettlitz & Austria & $4823 \mathrm{~N}$ & $15027 \mathrm{E}$ & Graphite & Metamorphic & McFaul and others, 2000. \\
\hline Erzberg & Austria & $4733 \mathrm{~N}$ & $14056 \mathrm{E}$ & Iron, Manganese & Sedimentary & Kirkham and Rafer, 2003. \\
\hline Kaiserberg & Austria & $4721 \mathrm{~N}$ & $15004 \mathrm{E}$ & Graphite & Metamorphic & Krauss and others, 1989. \\
\hline Mittersill & Austria & $4712 \mathrm{~N}$ & $12028 \mathrm{E}$ & Tungsten & Sedimentary & McFaul and others, 2000. \\
\hline Trieben & Austria & $4729 \mathrm{~N}$ & $14030 \mathrm{E}$ & Graphite & Metamorphic & Krauss and others, 1989. \\
\hline Dashkesan & Azerbaijan & $4031 \mathrm{~N}$ & $464 \mathrm{E}$ & Iron, Cobalt & Igneous & Levine, 1998. \\
\hline Okolovskoye & Belarus & $52560 \mathrm{~N}$ & $30320 \mathrm{E}$ & Iron & Sedimentary & Kirkham and Rafer, 2003. \\
\hline Bleiberg & Belgium & $5043 \mathrm{~N}$ & $0555 \mathrm{E}$ & Lead, Zinc & Sedimentary & Kirkham and Rafer, 2003. \\
\hline Asarel & Bulgaria & $4232 \mathrm{~N}$ & $2411 \mathrm{E}$ & Copper, Gold & Hydrothermal & Singer and others, 2002. \\
\hline Chelopech & Bulgaria & $4230 \mathrm{~N}$ & $2400 \mathrm{E}$ & Gold, Copper & Hydrothermal & Kirkham and Rafer, 2003. \\
\hline Elatsite & Bulgaria & $4249 \mathrm{~N}$ & $2359 \mathrm{E}$ & Copper & Hydrothermal & Singer and others, 2002. \\
\hline Gorubso-Kombinat & Bulgaria & $4126 \mathrm{~N}$ & $2459 \mathrm{E}$ & Lead, Zinc, Silver & Hydrothermal & Triller and Lauenstein, 1987. \\
\hline Medet & Bulgaria & $4243 \mathrm{~N}$ & $245 \mathrm{E}$ & Copper, Molybdenum & Hydrothermal & Singer and others, 2002. \\
\hline Obrochishte & Bulgaria & $4323 \mathrm{~N}$ & $284 \mathrm{E}$ & Manganese & Sedimentary & Lode, 2003, \\
\hline Varana District & Bulgaria & $4323 \mathrm{~N}$ & $2755 \mathrm{E}$ & Manganese & Sedimentary & McFaul and others, 2000. \\
\hline Cesky-Krumlov & Czech Republic & $4848 \mathrm{~N}$ & $14019 \mathrm{E}$ & Graphite & Metamorphic & Krauss and others, 1989. \\
\hline Kolledeye & Czech Republic & $4913 \mathrm{~N}$ & $14027 \mathrm{E}$ & Graphite & Metamorphic & Krauss and others, 1989. \\
\hline Krasno & Czech Republic & $506 \mathrm{~N}$ & $12048 \mathrm{E}$ & Tin, Tungsten & Hydrothermal & Werner and others, 1998. \\
\hline Mestsky-Vrch & Czech Republic & $4851 \mathrm{~N}$ & $14018 \mathrm{E}$ & Graphite & Metamorphic & Krauss and others, 1989. \\
\hline
\end{tabular}


Table 2A. Mineral deposit name, location, principal commodities, type, and reference for the major metallic mineral deposits in Greenland, Europe, Russia, and Northern Central Asia. Table includes some duplications because of variable transliteration methods. Transliterations of names according to source reference.

\begin{tabular}{|c|c|c|c|c|c|c|}
\hline Deposit Name & Country & Latitude & Longitude & Commodities & Deposit Type & Reference \\
\hline Velke Vrbno-Konstantin & Czech Republic & $508 \mathrm{~N}$ & $17020 \mathrm{E}$ & Graphite & Metamorphic & Hruska, 1991. \\
\hline Enonkoski & Finland & $625 \mathrm{~N}$ & $2855 \mathrm{E}$ & Nickel, Copper & Igneous & DeYoung and others, 1985. \\
\hline Hitura & Finland & $6351 \mathrm{~N}$ & $253 \mathrm{E}$ & $\begin{array}{l}\text { Nickel, Copper, Platinum Group } \\
\text { Elements }\end{array}$ & Igneous & DeYoung and others, 1985. \\
\hline Juomasuo & Finland & $6619 \mathrm{~N}$ & $2548 \mathrm{E}$ & Gold, Cobalt & Hydrothermal & Gold in Finland, 2004. \\
\hline Kemi & Finland & $6547 \mathrm{~N}$ & $2443 \mathrm{E}$ & Chromium & Igneous & McFaul and others, 2000. \\
\hline Kotalahti & Finland & $6214 \mathrm{~N}$ & $2737 \mathrm{E}$ & $\begin{array}{l}\text { Nickel, Copper, Platinum Group } \\
\text { Elements }\end{array}$ & Igneous & DeYoung and others, 1985. \\
\hline Kutemajarvi & Finland & $6136 \mathrm{~N}$ & $2218 \mathrm{E}$ & Gold & Hydrothermal & Gold in Finland, 2004. \\
\hline Lahnaslampi (Sotkamo) & Finland & $648 \mathrm{~N}$ & $2825 \mathrm{E}$ & Nickel, Magnesium & Hydrothermal & Benbow, 1991. \\
\hline Lapeenranta & Finland & $614 \mathrm{~N}$ & $2815 \mathrm{E}$ & Tungsten & Sedimentary & Benbow, 1991. \\
\hline Mullikkoräme & Finland & $6341 \mathrm{~N}$ & $2747 \mathrm{E}$ & Zinc, Copper & Hydrothermal & $\begin{array}{l}\text { Zinc deposits in Finland, } \\
2004 .\end{array}$ \\
\hline Mustavaara & Finland & $6528 \mathrm{~N}$ & $2759 \mathrm{E}$ & Vanadium, Titanium, Iron & Igneous & Goldberg and others, 1992. \\
\hline Orivesi & Finland & $6141 \mathrm{~N}$ & $2421 \mathrm{E}$ & Gold & Hydrothermal & Gold in Finland, 2004. \\
\hline Otanmaki & Finland & $6415 \mathrm{~N}$ & $2810 \mathrm{E}$ & Titanium & Igneous & Towner and others 1988. \\
\hline Outokumpu district & Finland & $6234 \mathrm{~N}$ & $2858 \mathrm{E}$ & Copper, Zinc, Cobalt, Nickel & Hydrothermal & Lode, 2003. \\
\hline Pampalo & Finland & $630 \mathrm{~N}$ & $3112 \mathrm{E}$ & Gold & Hydrothermal & Gold in Finland, 2004. \\
\hline Portimo & Finland & $6326 \mathrm{~N}$ & $2245 \mathrm{E}$ & Platinum Group Elements, Gold & Igneous & Wilburn, 2004. \\
\hline Pyhasalmi & Finland & $6339 \mathrm{~N}$ & $2203 \mathrm{E}$ & Zinc, Copper & Hydrothermal & McFaul and others, 2000. \\
\hline Sokli & Finland & $6745 \mathrm{~N}$ & $2915 \mathrm{E}$ & Rare Earth Elements, Phosphate & Igneous & Benbow, 1991. \\
\hline Suurikiisikko & Finland & $6742 \mathrm{~N}$ & $2507 \mathrm{E}$ & Gold & Hydrothermal & Gold in Finland, 2004. \\
\hline Vammala & Finland & $6120 \mathrm{~N}$ & $2454 \mathrm{E}$ & $\begin{array}{l}\text { Nickel, Copper, Platinum Group } \\
\text { Elements }\end{array}$ & Igneous & DeYoung and others, 1985. \\
\hline Vihanti & Finland & $6429 \mathrm{~N}$ & $258 \mathrm{E}$ & Zinc, Lead, Silver, Gold, Copper & Hydrothermal & McFaul and others, 2000. \\
\hline Vuonos/Keretti & Finland & $6245 \mathrm{~N}$ & $2842 \mathrm{E}$ & Nickel, Cobalt,Talc & Igneous & Crockett and others, 1987. \\
\hline Chaillac & France & $4626 \mathrm{~N}$ & $0120 \mathrm{E}$ & Iron, Barite & Sedimentary & Bouladon, 1989. \\
\hline Fumade & France & $4339 \mathrm{~N}$ & $0229 \mathrm{E}$ & Tungsten & Hydrothermal & Werner and others, 1998. \\
\hline
\end{tabular}


Table 2A. Mineral deposit name, location, principal commodities, type, and reference for the major metallic mineral deposits in Greenland, Europe, Russia, and Northern Central Asia. Table includes some duplications because of variable transliteration methods. Transliterations of names according to source reference.

\begin{tabular}{|c|c|c|c|c|c|c|}
\hline Deposit Name & Country & Latitude & Longitude & Commodities & Deposit Type & Reference \\
\hline Lorraine & France & $4922 \mathrm{~N}$ & $0603 \mathrm{E}$ & Iron & Sedimentary & Kirkham and Rafer, 2003. \\
\hline Saint-Salvy & France & $4339 \mathrm{~N}$ & $0224 \mathrm{E}$ & Zinc, Silver, Uranium & Sedimentary & Lode, 2003. \\
\hline Salsigne & France & $4319 \mathrm{~N}$ & $0221 \mathrm{E}$ & $\begin{array}{l}\text { Gold, Silver, Copper, Arsenic, } \\
\text { Bismuth }\end{array}$ & Hydrothermal & Lode, 2003. \\
\hline Chiatura & Georgia & $42141 \mathrm{~N}$ & $431450 \mathrm{E}$ & Manganese & Sedimentary & Natapov and others, 2000. \\
\hline Davidgaredzhinskoe & Georgia & $411942 \mathrm{~N}$ & $442217 \mathrm{E}$ & Lead, Barium & Hydrothermal & Natapov and others, 2000. \\
\hline Madneuli & Georgia & $4131 \mathrm{~N}$ & $4446 \mathrm{E}$ & $\begin{array}{l}\text { Copper, Lead, Zinc, Gold, Silver, } \\
\text { Barium }\end{array}$ & Igneous & Migineishvili, 2000. \\
\hline Rodinouli-Cholatunskoe & Georgia & $42729 \mathrm{~N}$ & $425713 \mathrm{E}$ & Manganese & Sedimentary & Natapov and others, 2000. \\
\hline Supsa-Natanebi & Georgia & $4240 \mathrm{~N}$ & $4155 \mathrm{E}$ & Iron, Titanium & Surficial & $\begin{array}{l}\text { Mineral Resources of } \\
\text { Georgia, } 2004 .\end{array}$ \\
\hline Zopkhito & Georgia & $4251 \mathrm{~N}$ & $4325 \mathrm{E}$ & Gold, Antimony & Hydrothermal & $\begin{array}{l}\text { Mineral Resources of } \\
\text { George, 2004: } \\
\text { www.mineralresources.ge }\end{array}$ \\
\hline Altenberg & Germany & $5046 \mathrm{~N}$ & $13048 \mathrm{E}$ & Tin & Hydrothermal & Kirkham and Rafer, 2003. \\
\hline Grund & Germany & $5151 \mathrm{~N}$ & $10014 \mathrm{E}$ & Copper & Hydrothermal & Triller and Lauenstein, 1987. \\
\hline Kropfmuehl & Germany & $4837 \mathrm{~N}$ & $13039 \mathrm{E}$ & Graphite & Metamorphic & Krauss and others, 1989. \\
\hline Maubach-Mechernich & Germany & $5027 \mathrm{~N}$ & $0640 \mathrm{E}$ & Lead, Zinc, Copper & Sedimentary & Lode, 2003. \\
\hline Meggen & Germany & $518 \mathrm{~N}$ & $0815 \mathrm{E}$ & Zinc, Lead, Barium & Sedimentary & McFaul and others, 2000. \\
\hline Rammelsberg & Germany & $5132 \mathrm{~N}$ & $10015 \mathrm{E}$ & $\begin{array}{l}\text { Zinc, Lead, Silver, Gold, Copper, } \\
\text { Barium }\end{array}$ & Sedimentary & Lode, 2003. \\
\hline Salzgitter & Germany & $523 \mathrm{~N}$ & $10025 \mathrm{E}$ & Iron & Sedimentary & Kirkham and Rafer, 2003. \\
\hline Ermioni & Greece & $3724 \mathrm{~N}$ & $2315 \mathrm{E}$ & Copper, Cobalt, Zinc & Hydrothermal & McFaul and others, 2000. \\
\hline Larymna/Euboea & Greece & $3828 \mathrm{~N}$ & $2317 \mathrm{E}$ & Nickel, Iron & Surficial & DeYoung and others, 1985. \\
\hline Olympias/Kassandra & Greece & $4036 \mathrm{~N}$ & $2346 \mathrm{E}$ & Gold, Lead, Zinc, Silver & Hydrothermal & Lode, 2003. \\
\hline Parnassos & Greece & $3832 \mathrm{~N}$ & $2237 \mathrm{E}$ & Aluminium & Surficial & Triller and Lauenstein, 1987. \\
\hline Skouries/Fioska & Greece & $4028 \mathrm{~N}$ & $2342 \mathrm{E}$ & Copper, Gold & Hydrothermal & Singer and others, 2002. \\
\hline Yerikini & Greece & $4015 \mathrm{~N}$ & $2327 \mathrm{E}$ & Magnesium & Hydrothermal & $\begin{array}{l}\text { Hatjilazaridou and others, } \\
1998\end{array}$ \\
\hline
\end{tabular}


Table 2A. Mineral deposit name, location, principal commodities, type, and reference for the major metallic mineral deposits in Greenland, Europe, Russia, and Northern Central Asia. Table includes some duplications because of variable transliteration methods. Transliterations of names according to source reference.

\begin{tabular}{|c|c|c|c|c|c|c|}
\hline Deposit Name & Country & Latitude & Longitude & Commodities & Deposit Type & Reference \\
\hline Bakony District & Hungary & $473 \mathrm{~N}$ & $17033 \mathrm{E}$ & Aluminium & Surficial & Triller and Lauenstein, 1987. \\
\hline Recsk-Lahoca & Hungary & $4754 \mathrm{~N}$ & $2005 \mathrm{E}$ & Copper, Lead, Zinc & Hydrothermal & Lode, 2003. \\
\hline Urkut District & Hungary & $4705 \mathrm{~N}$ & $17040 \mathrm{E}$ & Manganese & Sedimentary & DeYoung and others, 1984. \\
\hline Lisheen & Ireland & $5242 \mathrm{~N}$ & $0748 \mathrm{~W}$ & Zinc, Lead, Silver, Iron & Sedimentary & Lode, 2003. \\
\hline Silvermines & Ireland & $5247 \mathrm{~N}$ & $0814 \mathrm{~W}$ & Zinc, Lead, Silver, Barium & Sedimentary & Lode, 2003. \\
\hline Tara (Navan) & Ireland & $5336 \mathrm{~N}$ & $0642 \mathrm{~W}$ & Zinc, Lead & Sedimentary & Lode, 2003. \\
\hline Monteponi & Italy & $3917 \mathrm{~N}$ & $832 \mathrm{E}$ & Zinc, Lead, Gold & Sedimentary & McFaul and others, 2000. \\
\hline Muscadroxiu & Italy & $4000 \mathrm{~N}$ & $0900 \mathrm{E}$ & Lead, Fluorine, Barium & Hydrothermal & McFaul and others, 2000. \\
\hline Northern Italy District & Italy & $4555 \mathrm{~N}$ & $1006 \mathrm{E}$ & Fluorine, Zinc, Lead & Hydrothermal & McFaul and others, 2000. \\
\hline Osilo & Italy & $4041 \mathrm{~N}$ & $8040 \mathrm{E}$ & Gold, Silver & Hydrothermal & $\begin{array}{l}\text { Gold Mines of Sardinia, } \\
2004 .\end{array}$ \\
\hline Piampaludo & Italy & $4428 \mathrm{~N}$ & $8052 \mathrm{E}$ & Titanium, Garnet & Metamorphic & Towner and others, 1988. \\
\hline Pinerolo & Italy & $4453 \mathrm{~N}$ & $7019 \mathrm{E}$ & Graphite & Metamorphic & Krauss and others, 1989. \\
\hline Skouries/Fioska & Italy & $3928 \mathrm{~N}$ & $8057 \mathrm{E}$ & Gold, Silver & Hydrothermal & $\begin{array}{l}\text { Gold Mines of Sardinia, } \\
2004 .\end{array}$ \\
\hline Agpat, Ilimaussaq intrusion & $\begin{array}{l}\text { Kalaallit } \\
\text { Nunaat }\end{array}$ & $6056 \mathrm{~N}$ & $4545 \mathrm{~W}$ & Zirconium, Yttrium & Igneous & Secher, 2002. \\
\hline Black Angel & $\begin{array}{l}\text { Kalaallit } \\
\text { Nunaat }\end{array}$ & $715 \mathrm{~N}$ & $51140 \mathrm{~W}$ & Zinc, Lead, Silver & Sedimentary & Kirkham and Rafer, 2003. \\
\hline Citronen Fjord, Peary Land & $\begin{array}{l}\text { Kalaallit } \\
\text { Nunaat }\end{array}$ & $8306 \mathrm{~N}$ & $2920 \mathrm{~W}$ & Zinc, Lead & Sedimentary & Kirkham and Rafer, 2003. \\
\hline Fiskenaesset & $\begin{array}{l}\text { Kalaallit } \\
\text { Nunaat }\end{array}$ & $6306 \mathrm{~N}$ & $5040 \mathrm{~W}$ & Chromium & Igneous & Henriksen and others, 2000. \\
\hline Isua & $\begin{array}{l}\text { Kalaallit } \\
\text { Nunaat }\end{array}$ & $6430 \mathrm{~N}$ & $5000 \mathrm{~W}$ & Iron & Sedimentary & Kirkham and Rafer, 2003. \\
\hline $\begin{array}{l}\text { Kringlerne, Ilimaussaq } \\
\text { intrusion }\end{array}$ & $\begin{array}{l}\text { Kalaallit } \\
\text { Nunaat }\end{array}$ & $605205 \mathrm{~N}$ & $455138 \mathrm{~W}$ & $\begin{array}{l}\text { Zirconium, Yttrium, Rare Earth } \\
\text { Elements, Niobium }\end{array}$ & Igneous & Schjøth and others, 2000. \\
\hline Ladderbjerg & $\begin{array}{l}\text { Kalaallit } \\
\text { Nunaat }\end{array}$ & $732945 \mathrm{~N}$ & $220145 \mathrm{~W}$ & Copper & Sedimentary & Cox and others, 2003. \\
\hline Malmbjerg & $\begin{array}{l}\text { Kalaallit } \\
\text { Nunaat }\end{array}$ & $7155 \mathrm{~N}$ & $2415 \mathrm{~W}$ & Molybdenum & Igneous & Kirkham and Rafer, 2003. \\
\hline
\end{tabular}


Table 2A. Mineral deposit name, location, principal commodities, type, and reference for the major metallic mineral deposits in Greenland, Europe, Russia, and Northern Central Asia. Table includes some duplications because of variable transliteration methods. Transliterations of names according to source reference.

\begin{tabular}{|c|c|c|c|c|c|c|}
\hline Deposit Name & Country & Latitude & Longitude & Commodities & Deposit Type & Reference \\
\hline $\begin{array}{l}\text { Motzfeldt Centre, Igaliko } \\
\text { nepheline syenite }\end{array}$ & $\begin{array}{l}\text { Kalaallit } \\
\text { Nunaat }\end{array}$ & $6115 \mathrm{~N}$ & $4500 \mathrm{~W}$ & Niobium, Zirconium, Tantalum & Igneous & Kirkham and Rafer, 2003. \\
\hline Nalunaq & $\begin{array}{l}\text { Kalaallit } \\
\text { Nunaat }\end{array}$ & $602121 \mathrm{~N}$ & $445003 \mathrm{~W}$ & Gold & Hydrothermal & Stendal and Secher, 2002. \\
\hline $\begin{array}{l}\text { Platinova Reef, Skaergaard } \\
\text { Intrusion }\end{array}$ & $\begin{array}{l}\text { Kalaallit } \\
\text { Nunaat }\end{array}$ & $68120 \mathrm{~N}$ & $31500 \mathrm{~W}$ & Gold, Palladium & Igneous & Nielsen, 2001. \\
\hline Qaqqaarsuk & $\begin{array}{l}\text { Kalaallit } \\
\text { Nunaat }\end{array}$ & $65230 \mathrm{~N}$ & $51420 \mathrm{~W}$ & Niobium, Phosphorus & Igneous & Mining Journal, 2000. \\
\hline Rubjerg Knude & $\begin{array}{l}\text { Kalaallit } \\
\text { Nunaat }\end{array}$ & $72372 \mathrm{~N}$ & $234050 \mathrm{~W}$ & Copper & Sedimentary & Cox and others, 2003. \\
\hline Sarfartoq & $\begin{array}{l}\text { Kalaallit } \\
\text { Nunaat }\end{array}$ & $66300 \mathrm{~N}$ & $51150 \mathrm{~W}$ & Phosphorus, Niobium & Igneous & Mining Journal, 2000. \\
\hline 20 Let KazSSR & Kazakhstan & $5019 \mathrm{~N}$ & $5826 \mathrm{E}$ & Chromium & Igneous & Seltmann and others, 2003. \\
\hline 50 Let Oktyabrya & Kazakhstan & $5028 \mathrm{~N}$ & $599 \mathrm{E}$ & Copper & Hydrothermal & Seltmann and others, 2003. \\
\hline Achisai & Kazakhstan & $4334 \mathrm{~N}$ & $6854 \mathrm{E}$ & Lead, Zinc & Sedimentary & Seltmann and others, 2003. \\
\hline Aidarly & Kazakhstan & $4660 \mathrm{~N}$ & $7955 \mathrm{E}$ & Copper, Molybdenum & Igneous & Seltmann and others, 2003. \\
\hline Ainalma & Kazakhstan & $4332 \mathrm{~N}$ & $6836 \mathrm{E}$ & Lead, Zinc, Barium & Sedimentary & Seltmann and others, 2003. \\
\hline Ajatskoe 1 & Kazakhstan & $524355 \mathrm{~N}$ & $625452 \mathrm{E}$ & Aluminium & Sedimentary & Natapov and others, 2000. \\
\hline Akchatau & Kazakhstan & $47575 \mathrm{~N}$ & $74457 \mathrm{E}$ & $\begin{array}{l}\text { Tungsten, Molybdenum, Beryllium, } \\
\text { Bismuth }\end{array}$ & Hydrothermal & Natapov and others, 2000. \\
\hline Aktogajskoe & Kazakhstan & $483015 \mathrm{~N}$ & $59250 \mathrm{E}$ & Aluminium & Sedimentary & Natapov and others, 2000. \\
\hline Alajgyr & Kazakhstan & $49311 \mathrm{~N}$ & $74295 \mathrm{E}$ & Lead, Silver & Hydrothermal & Natapov and others, 2000. \\
\hline Aleshinskoe & Kazakhstan & $534911 \mathrm{~N}$ & $634211 \mathrm{E}$ & Iron & Hydrothermal & Seltmann and others, 2003. \\
\hline $\begin{array}{l}\text { Almaz-Zhemchuzhina, } \\
\text { Geofizicheskoe }\end{array}$ & Kazakhstan & $501418 \mathrm{~N}$ & $582814 \mathrm{E}$ & Chromium & Igneous & Seltmann and others, 2003. \\
\hline Aqbakai & Kazakhstan & $457 \mathrm{~N}$ & $7241 \mathrm{E}$ & Gold, Arsenic & Igneous & Seltmann and others, 2003. \\
\hline Aqchatau & Kazakhstan & $480 \mathrm{~N}$ & $742 \mathrm{E}$ & Tungsten, Beryllium, Molybdenum & Igneous & Seltmann and others, 2003. \\
\hline Aqtash & Kazakhstan & $4232 \mathrm{~N}$ & $736 \mathrm{E}$ & Gold & Igneous & Seltmann and others, 2003. \\
\hline Aqtogai & Kazakhstan & $4659 \mathrm{~N}$ & $7960 \mathrm{E}$ & Copper, Molybdenum & Igneous & Seltmann and others, 2003. \\
\hline Aqzhal & Kazakhstan & $4745 \mathrm{~N}$ & $741 \mathrm{E}$ & Lead, Zinc & Sedimentary & Seltmann and others, 2003. \\
\hline
\end{tabular}


Table 2A. Mineral deposit name, location, principal commodities, type, and reference for the major metallic mineral deposits in Greenland, Europe, Russia, and Northern Central Asia. Table includes some duplications because of variable transliteration methods. Transliterations of names according to source reference.

\begin{tabular}{|c|c|c|c|c|c|c|}
\hline Deposit Name & Country & Latitude & Longitude & Commodities & Deposit Type & Reference \\
\hline Aurtash & Kazakhstan & $434348 \mathrm{~N}$ & $51535 \mathrm{E}$ & Strontium & Sedimentary & Natapov and others, 2000. \\
\hline Ayatskoe & Kazakhstan & $5240 \mathrm{~N}$ & $6232 \mathrm{E}$ & Iron & Sedimentary & Seltmann and others, 2003. \\
\hline Balakauskandynskoe & Kazakhstan & $442917 \mathrm{~N}$ & $671737 \mathrm{E}$ & Vanadium & Hydrothermal & Natapov and others, 2000. \\
\hline Baqyrchik & Kazakhstan & $4929 \mathrm{~N}$ & $8131 \mathrm{E}$ & Gold & Hydrothermal & Seltmann and others, 2003. \\
\hline Batystau & Kazakhstan & $481717 \mathrm{~N}$ & $734926 \mathrm{E}$ & Tungsten, Molybdenum, Beryllium & Hydrothermal & Seltmann and others, 2003. \\
\hline Belogorskoe & Kazakhstan & $4928 \mathrm{~N}$ & $836 \mathrm{E}$ & $\begin{array}{l}\text { Tantalum, Tin, Niobium, Beryllium, } \\
\text { Lithium }\end{array}$ & Igneous & Seltmann and others, 2003. \\
\hline Beloubinskoe & Kazakhstan & $5040 \mathrm{~N}$ & $8337 \mathrm{E}$ & Lead, Zinc, Copper & Hydrothermal & Seltmann and others, 2003. \\
\hline Belousovskoe & Kazakhstan & $501151 \mathrm{~N}$ & $82265 \mathrm{E}$ & Lead, Zinc, Copper & Hydrothermal & Seltmann and others, 2003. \\
\hline Benqala North & Kazakhstan & $5112 \mathrm{~N}$ & $6147 \mathrm{E}$ & Copper, Molybdenum & Igneous & Seltmann and others, 2003. \\
\hline Benqala South & Kazakhstan & $516 \mathrm{~N}$ & $6149 \mathrm{E}$ & Copper, Molybdenum & Igneous & Seltmann and others, 2003. \\
\hline Bestobe & Kazakhstan & $489 \mathrm{~N}$ & $7112 \mathrm{E}$ & Lead, Zinc, Iron & Sedimentary & Seltmann and others, 2003. \\
\hline Bestobe West & Kazakhstan & $5231 \mathrm{~N}$ & $737 \mathrm{E}$ & Gold & Igneous & Seltmann and others, 2003. \\
\hline Bochetkol'skoe & Kazakhstan & $503523 \mathrm{~N}$ & $605344 \mathrm{E}$ & Nickel, Cobalt & Surficial & Natapov and others, 2000. \\
\hline Boguty & Kazakhstan & $4332 \mathrm{~N}$ & $7857 \mathrm{E}$ & Tungsten & Igneous & Seltmann and others, 2003. \\
\hline Bolshevik & Kazakhstan & $4945 \mathrm{~N}$ & $8112 \mathrm{E}$ & Gold & Hydrothermal & Seltmann and others, 2003. \\
\hline Bosaga & Kazakhstan & $483629 \mathrm{~N}$ & $755029 \mathrm{E}$ & Aluminium & Hydrothermal & Natapov and others, 2000. \\
\hline Bozshakol & Kazakhstan & $5151 \mathrm{~N}$ & $7419 \mathrm{E}$ & Copper, Molybdenum & Igneous & Seltmann and others, 2003. \\
\hline Bulandy & Kazakhstan & $4854 \mathrm{~N}$ & $8415 \mathrm{E}$ & Tungsten & Igneous & Seltmann and others, 2003. \\
\hline Donetskoe & Kazakhstan & $5331 \mathrm{~N}$ & $6939 \mathrm{E}$ & Tin & Igneous & Seltmann and others, 2003. \\
\hline Donskoy & Kazakhstan & $505 \mathrm{~N}$ & $595 \mathrm{E}$ & Chromium & Igneous & Levine, 1998. \\
\hline Dorozhilovskoe & Kazakhstan & $5239 \mathrm{~N}$ & $6124 \mathrm{E}$ & Molybdenum & Igneous & Seltmann and others, 2003. \\
\hline Druzhba B & Kazakhstan & $5127 \mathrm{~N}$ & $7633 \mathrm{E}$ & Titanium, Zirconium & Surficial & Seltmann and others, 2003. \\
\hline Dzhezqasghan & Kazakhstan & $484 \mathrm{~N}$ & $6615 \mathrm{E}$ & Copper & Sedimentary & Seltmann and others, 2003. \\
\hline Geophizicheskoe & Kazakhstan & $5017 \mathrm{~N}$ & $5831 \mathrm{E}$ & Chromium & Igneous & Seltmann and others, 2003. \\
\hline Grekhovskoe & Kazakhstan & $4942 \mathrm{~N}$ & $8425 \mathrm{E}$ & Lead, Zinc & Hydrothermal & Seltmann and others, 2003. \\
\hline Gvardejskoe & Kazakhstan & $461644 \mathrm{~N}$ & $701113 \mathrm{E}$ & Iron & Sedimentary & Natapov and others, 2000. \\
\hline
\end{tabular}


Table 2A. Mineral deposit name, location, principal commodities, type, and reference for the major metallic mineral deposits in Greenland, Europe, Russia, and Northern Central Asia. Table includes some duplications because of variable transliteration methods. Transliterations of names according to source reference.

\begin{tabular}{|c|c|c|c|c|c|c|}
\hline Deposit Name & Country & Latitude & Longitude & Commodities & Deposit Type & Reference \\
\hline Kacharskoe & Kazakhstan & $53218 \mathrm{~N}$ & $625636 \mathrm{E}$ & Iron & Hydrothermal & Seltmann and others, 2003. \\
\hline Karatas & Kazakhstan & $46375 \mathrm{~N}$ & $734659 \mathrm{E}$ & Molybdenum, Copper & Igneous & Natapov and others, 2000. \\
\hline Karsaqpai & Kazakhstan & $4746 \mathrm{~N}$ & $6646 \mathrm{E}$ & Iron & Sedimentary & Seltmann and others, 2003. \\
\hline Katpar North & Kazakhstan & $4844 \mathrm{~N}$ & $7257 \mathrm{E}$ & Tungsten, Molybdenum & Igneous & Seltmann and others, 2003. \\
\hline Kempirsai & Kazakhstan & $5036 \mathrm{~N}$ & $5815 \mathrm{E}$ & $\begin{array}{l}\text { Chromium, Platinum Group } \\
\text { Elements, Nickel }\end{array}$ & Igneous & Kirkham and Rafer, 2003. \\
\hline Kijakinskoe & Kazakhstan & $494011 \mathrm{~N}$ & $601115 \mathrm{E}$ & Iron & Hydrothermal & Natapov and others, 2000. \\
\hline Koksai & Kazakhstan & $4429 \mathrm{~N}$ & $7828 \mathrm{E}$ & Copper, Molybdenum & Igneous & Seltmann and others, 2003. \\
\hline Koktauskoe & Kazakhstan & $501411 \mathrm{~N}$ & $663539 \mathrm{E}$ & Aluminium & Metamorphic & Natapov and others, 2000. \\
\hline Koktenkol & Kazakhstan & $4837 \mathrm{~N}$ & $7215 \mathrm{E}$ & Molybdenum, Tungsten & Igneous & Seltmann and others, 2003. \\
\hline Konyrat & Kazakhstan & $4659 \mathrm{~N}$ & $7460 \mathrm{E}$ & Molybdenum, Copper & Igneous & Seltmann and others, 2003. \\
\hline Krasnooktjabr'skoe & Kazakhstan & $52543 \mathrm{~N}$ & $622751 \mathrm{E}$ & Aluminium & Sedimentary & Natapov and others, 2000. \\
\hline Kubasadyrskoe & Kazakhstan & $511743 \mathrm{~N}$ & $663625 \mathrm{E}$ & Aluminium, Vermiculite & Surficial & Natapov and others, 2000. \\
\hline Kumkol'skoe & Kazakhstan & $504442 \mathrm{~N}$ & $61546 \mathrm{E}$ & Titanium & Surficial & Natapov and others, 2000. \\
\hline Kundybai & Kazakhstan & $5153 \mathrm{~N}$ & $6048 \mathrm{E}$ & Zirconium, Thorium, Beryllium & Igneous & Seltmann and others, 2003. \\
\hline Kundybajskoe & Kazakhstan & $515937 \mathrm{~N}$ & $604949 \mathrm{E}$ & Rare Earth Elements & Hydrothermal & Natapov and others, 2000. \\
\hline $\begin{array}{l}\text { Kundybajskoe, } \\
\text { Shevchenkovskoe }\end{array}$ & Kazakhstan & $514411 \mathrm{~N}$ & $604634 \mathrm{E}$ & Nickel, Cobalt & Surficial & Natapov and others, 2000. \\
\hline Kurumsak & Kazakhstan & $4419 \mathrm{~N}$ & $6738 \mathrm{E}$ & Vanadium & Sedimentary & Seltmann and others, 2003. \\
\hline Kvartsitovye Gorki & Kazakhstan & $5228 \mathrm{~N}$ & $720 \mathrm{E}$ & Gold & Igneous & Seltmann and others, 2003. \\
\hline Lisakovskoe & Kazakhstan & $523153 \mathrm{~N}$ & $622936 \mathrm{E}$ & Iron & Sedimentary & Seltmann and others, 2003. \\
\hline Losevskoe & Kazakhstan & $524440 \mathrm{~N}$ & $69048 \mathrm{E}$ & Zirconium, Tantalum & Igneous & Seltmann and others, 2003. \\
\hline Maikain & Kazakhstan & $5129 \mathrm{~N}$ & $7548 \mathrm{E}$ & Gold & Hydrothermal & Seltmann and others, 2003. \\
\hline Maleevskoe & Kazakhstan & $4953 \mathrm{~N}$ & $8419 \mathrm{E}$ & Copper & Hydrothermal & Seltmann and others, 2003. \\
\hline Mirgalimsai & Kazakhstan & $4333 \mathrm{~N}$ & $6833 \mathrm{E}$ & Lead, Zinc & Sedimentary & Seltmann and others, 2003. \\
\hline Mizek & Kazakhstan & $48577 \mathrm{~N}$ & $772525 \mathrm{E}$ & Copper, Zinc, Gold & Hydrothermal & Natapov and others, 2000. \\
\hline Molodiezhnoe & Kazakhstan & $5021 \mathrm{~N}$ & $5831 \mathrm{E}$ & Chromium & Igneous & Seltmann and others, 2003. \\
\hline
\end{tabular}


Table 2A. Mineral deposit name, location, principal commodities, type, and reference for the major metallic mineral deposits in Greenland, Europe, Russia, and Northern Central Asia. Table includes some duplications because of variable transliteration methods. Transliterations of names according to source reference.

\begin{tabular}{|c|c|c|c|c|c|c|}
\hline Deposit Name & Country & Latitude & Longitude & Commodities & Deposit Type & Reference \\
\hline Nikolaevskoe & Kazakhstan & $502957 \mathrm{~N}$ & $815118 \mathrm{E}$ & Zinc, Copper, Lead & Hydrothermal & Natapov and others, 2000. \\
\hline Nurataldy & Kazakhstan & $49754 \mathrm{~N}$ & $732841 \mathrm{E}$ & Molybdenum, Tungsten, Beryllium & Igneous & Seltmann and others, 2003. \\
\hline Nurkazgan & Kazakhstan & $509 \mathrm{~N}$ & $731 \mathrm{E}$ & Gold, Copper, Molybdenum & Igneous & Seltmann and others, 2003. \\
\hline Oktjabr'skoe & Kazakhstan & $503514 \mathrm{~N}$ & $58439 \mathrm{E}$ & Nickel, Cobalt & Surficial & Natapov and others, 2000. \\
\hline Priorskoe & Kazakhstan & $5032 \mathrm{~N}$ & $594 \mathrm{E}$ & Copper & Hydrothermal & Seltmann and others, 2003. \\
\hline Qaraghaily & Kazakhstan & $4922 \mathrm{~N}$ & $7543 \mathrm{E}$ & Lead, Zinc, Barium & Sedimentary & Seltmann and others, 2003. \\
\hline Qaraoba & Kazakhstan & $4713 \mathrm{~N}$ & $7125 \mathrm{E}$ & Tungsten, Molybdenum & Igneous & Seltmann and others, 2003. \\
\hline Qarazhal West & Kazakhstan & $481 \mathrm{~N}$ & $7049 \mathrm{E}$ & Iron, Manganese & Sedimentary & Seltmann and others, 2003. \\
\hline Qonyrat (Kounrad) & Kazakhstan & $470 \mathrm{~N}$ & $7445 \mathrm{E}$ & $\begin{array}{l}\text { Copper, Molybdenum, Gold, } \\
\text { Rhenium }\end{array}$ & Igneous & Kudryavtsev, 1996. \\
\hline Ridder-Sokol'noe & Kazakhstan & $5022 \mathrm{~N}$ & $8332 \mathrm{E}$ & Lead, Zinc & Hydrothermal & Seltmann and others, 2003. \\
\hline Sar-Kol' & Kazakhstan & $49548 \mathrm{~N}$ & $583717 \mathrm{E}$ & Aluminium & Sedimentary & Natapov and others, 2000. \\
\hline Sarbai & Kazakhstan & $5311 \mathrm{~N}$ & $635 \mathrm{E}$ & Iron & Hydrothermal & Seltmann and others, 2003. \\
\hline Saryoba & Kazakhstan & $4810 \mathrm{~N}$ & $6728 \mathrm{E}$ & Copper & Sedimentary & Seltmann and others, 2003. \\
\hline Sarysai & Kazakhstan & $4735 \mathrm{~N}$ & $6619 \mathrm{E}$ & Vanadium & Sedimentary & Seltmann and others, 2003. \\
\hline Sayak-II (Tastau) & Kazakhstan & $470 \mathrm{~N}$ & $7725 \mathrm{E}$ & Copper, Molybdenum & Igneous & Seltmann and others, 2003. \\
\hline Shalkiya & Kazakhstan & $441 \mathrm{~N}$ & $6728 \mathrm{E}$ & Lead, Zinc & Sedimentary & Seltmann and others, 2003. \\
\hline Singirbajskaja & Kazakhstan & $495320 \mathrm{~N}$ & $604520 \mathrm{E}$ & Titanium, Zirconium & Surficial & Natapov and others, 2000. \\
\hline Smirnovskoe & Kazakhstan & $53330 \mathrm{~N}$ & $62732 \mathrm{E}$ & Molybdenum, Copper & Igneous & Natapov and others, 2000. \\
\hline Sokurkoj & Kazakhstan & $46305 \mathrm{~N}$ & $74734 \mathrm{E}$ & Aluminium & Hydrothermal & Natapov and others, 2000. \\
\hline Solnechnoe & Kazakhstan & $471527 \mathrm{~N}$ & $711432 \mathrm{E}$ & Tungsten, Fluorine & Hydrothermal & Natapov and others, 2000. \\
\hline Syrymbet & Kazakhstan & $531913 \mathrm{~N}$ & $68425 \mathrm{E}$ & Tin & Igneous & Seltmann and others, 2003. \\
\hline Tekeli & Kazakhstan & $4447 \mathrm{~N}$ & $7856 \mathrm{E}$ & Lead, Zinc & Sedimentary & Seltmann and others, 2003. \\
\hline Tishinskoe & Kazakhstan & $5018 \mathrm{~N}$ & $8322 \mathrm{E}$ & Lead, Zinc & Hydrothermal & Seltmann and others, 2003. \\
\hline Ushqatyn & Kazakhstan & $4822 \mathrm{~N}$ & $7022 \mathrm{E}$ & Lead, Zinc & Sedimentary & Seltmann and others, 2003. \\
\hline Uzynjal & Kazakhstan & $4734 \mathrm{~N}$ & $7239 \mathrm{E}$ & Lead, Zinc & Sedimentary & Seltmann and others, 2003. \\
\hline Vasil'evskoe & Kazakhstan & $4984 \mathrm{~N}$ & $813518 \mathrm{E}$ & Gold, Platinum & Igneous & Natapov and others, 2000. \\
\hline
\end{tabular}


Table 2A. Mineral deposit name, location, principal commodities, type, and reference for the major metallic mineral deposits in Greenland, Europe, Russia, and Northern Central Asia. Table includes some duplications because of variable transliteration methods. Transliterations of names according to source reference.

\begin{tabular}{|c|c|c|c|c|c|c|}
\hline Deposit Name & Country & Latitude & Longitude & Commodities & Deposit Type & Reference \\
\hline Vasil'kovskoe & Kazakhstan & $53212 \mathrm{~N}$ & $691546 \mathrm{E}$ & Gold & Igneous & Natapov and others, 2000. \\
\hline Verkhnee Espe & Kazakhstan & $4811 \mathrm{~N}$ & $8127 \mathrm{E}$ & $\begin{array}{l}\text { Zirconium, Niobium, Rare Earth } \\
\text { Elements }\end{array}$ & Igneous & Seltmann and others, 2003. \\
\hline Verkhnee Qairaqty & Kazakhstan & $4841 \mathrm{~N}$ & $7315 \mathrm{E}$ & Tungsten & Igneous & Seltmann and others, 2003. \\
\hline Verkhnekajraktinskoe & Kazakhstan & $483855 \mathrm{~N}$ & $73130 \mathrm{E}$ & Tungsten, Bismuth, Molybdenum & Hydrothermal & Natapov and others, 2000. \\
\hline $\begin{array}{l}\text { Vostochnyj Kounrad, } \\
\text { Severnyj Kounrad }\end{array}$ & Kazakhstan & $47037 \mathrm{~N}$ & $75129 \mathrm{E}$ & Tungsten, Molybdenum, Beryllium & Hydrothermal & Natapov and others, 2000. \\
\hline Zapadno-Ubaganskoe & Kazakhstan & $524838 \mathrm{~N}$ & $64457 \mathrm{E}$ & Aluminium & Sedimentary & Natapov and others, 2000. \\
\hline Zhairem & Kazakhstan & $4816 \mathrm{~N}$ & $7016 \mathrm{E}$ & Lead, Zinc & Sedimentary & Seltmann and others, 2003. \\
\hline Zhaman-Aibat & Kazakhstan & $4650 \mathrm{~N}$ & $6845 \mathrm{E}$ & Copper & Sedimentary & Seltmann and others, 2003. \\
\hline Zhanet & Kazakhstan & $473219 \mathrm{~N}$ & $742125 \mathrm{E}$ & Molybdenum & Igneous & Seltmann and others, 2003. \\
\hline Zholymbet & Kazakhstan & $5145 \mathrm{~N}$ & $7145 \mathrm{E}$ & Gold & Igneous & Seltmann and others, 2003. \\
\hline Zyryanovskoe & Kazakhstan & $4945 \mathrm{~N}$ & $8418 \mathrm{E}$ & Lead, Zinc & Hydrothermal & Seltmann and others, 2003. \\
\hline Andash & Kyrgyzstan & $4232 \mathrm{~N}$ & $7260 \mathrm{E}$ & Gold, Copper & Igneous & Seltmann and others, 2003. \\
\hline Aqtyuz & Kyrgyzstan & $4253 \mathrm{~N}$ & $7611 \mathrm{E}$ & Rare Earth Elements, Lead & Igneous & Seltmann and others, 2003. \\
\hline Bala-Chichkan & Kyrgyzstan & $4228 \mathrm{~N}$ & $7237 \mathrm{E}$ & Iron, Titanium, Vanadium & Igneous & Seltmann and others, 2003. \\
\hline Chaarat & Kyrgyzstan & $422 \mathrm{~N}$ & $7112 \mathrm{E}$ & Gold, Antimony & Igneous & Seltmann and others, 2003. \\
\hline Chonkoy & Kyrgyzstan & $4023 \mathrm{~N}$ & $7226 \mathrm{E}$ & Mercury & Hydrothermal & Seltmann and others, 2003. \\
\hline Dangy & Kyrgyzstan & $4131 \mathrm{~N}$ & $7642 \mathrm{E}$ & Iron & Igneous & Seltmann and others, 2003. \\
\hline Janguz-Bulak & Kyrgyzstan & $3957 \mathrm{~N}$ & $7120 \mathrm{E}$ & $\begin{array}{l}\text { Mercury, Antimony, Fluorine, } \\
\text { Arsenic }\end{array}$ & Hydrothermal & Seltmann and others, 2003. \\
\hline Jerooy & Kyrgyzstan & $4218 \mathrm{~N}$ & $7244 \mathrm{E}$ & Gold & Igneous & Seltmann and others, 2003. \\
\hline Kadamdjai & Kyrgyzstan & $407 \mathrm{~N}$ & $7144 \mathrm{E}$ & Antimony & Hydrothermal & Seltmann and others, 2003. \\
\hline Khaidarkan & Kyrgyzstan & $3957 \mathrm{~N}$ & $7122 \mathrm{E}$ & Mercury, Antimony, Fluorine & Hydrothermal & Seltmann and others, 2003. \\
\hline Kuku-Tegerek & Kyrgyzstan & $42036 \mathrm{~N}$ & $712750 \mathrm{E}$ & Gold, Silver, Copper & Hydrothermal & Seltman and others, 2003.. \\
\hline Kumtor & Kyrgyzstan & $415656 \mathrm{~N}$ & $77507 \mathrm{E}$ & Gold & Igneous & Seltmann and others, 2003. \\
\hline Kuru-Tegerek & Kyrgyzstan & $423 \mathrm{~N}$ & $7127 \mathrm{E}$ & Gold, Copper, Molybdenum & Igneous & Seltmann and others, 2003. \\
\hline Lyangar & Kyrgyzstan & $4024 \mathrm{~N}$ & $6557 \mathrm{E}$ & Tungsten, Molybdenum & Igneous & Seltmann and others, 2003. \\
\hline
\end{tabular}


Table 2A. Mineral deposit name, location, principal commodities, type, and reference for the major metallic mineral deposits in Greenland, Europe, Russia, and Northern Central Asia. Table includes some duplications because of variable transliteration methods. Transliterations of names according to source reference.

\begin{tabular}{|c|c|c|c|c|c|c|}
\hline Deposit Name & Country & Latitude & Longitude & Commodities & Deposit Type & Reference \\
\hline Makmal & Kyrgyzstan & $4111 \mathrm{~N}$ & $7359 \mathrm{E}$ & Gold & Igneous & Seltmann and others, 2003. \\
\hline Qara-Archa & Kyrgyzstan & $3957 \mathrm{~N}$ & $7124 \mathrm{E}$ & $\begin{array}{l}\text { Mercury, Antimony, Fluorine, } \\
\text { Arsenic }\end{array}$ & Hydrothermal & Seltmann and others, 2003. \\
\hline Taldybulak Levoberezhny & Kyrgyzstan & $4238 \mathrm{~N}$ & $7541 \mathrm{E}$ & Gold & Igneous & Seltmann and others, 2003. \\
\hline Terekskoe & Kyrgyzstan & $412913 \mathrm{~N}$ & $705511 \mathrm{E}$ & Antimony & Hydrothermal & Natapov and others, 2000. \\
\hline Uch-Imchek & Kyrgyzstan & $4220 \mathrm{~N}$ & $7148 \mathrm{E}$ & Arsenic, Silver & Hydrothermal & Seltmann and others, 2003. \\
\hline Uchkoshton & Kyrgyzstan & $414746 \mathrm{~N}$ & $78418 \mathrm{E}$ & Tin & Igneous & Natapov and others, 2000. \\
\hline Esch Rumelange & Luxenbourg & $4930 \mathrm{~N}$ & $0603 \mathrm{E}$ & Iron & Sedimentary & Kirkham and Rafer, 2003 \\
\hline Bucim & Macedonia & $4140 \mathrm{~N}$ & $2222 \mathrm{E}$ & Copper, Gold & Hydrothermal & Lode, 2003. \\
\hline Rzanovo & Macedonia & $4128 \mathrm{~N}$ & $2103 \mathrm{E}$ & Nickel. Cobalt & Surficial & Crockett and others, 1987. \\
\hline Flatt & Norway & $5836 \mathrm{~N}$ & $0752 \mathrm{E}$ & $\begin{array}{l}\text { Nickel, Copper, Platinum Group } \\
\text { Elements, Gold, Cobalt }\end{array}$ & Igneous & McFaul and others, 2000. \\
\hline Knaben & Norway & $5840 \mathrm{~N}$ & $0710 \mathrm{E}$ & Molybdenum & Hydrothermal & Kirkham and Rafer, 2003. \\
\hline Kongsberg & Norway & $5938 \mathrm{~N}$ & $0937 \mathrm{E}$ & Silver, Lead, Gold & Hydrothermal & Kirkham and Rafer, 2003. \\
\hline Lokken & Norway & $636 \mathrm{~N}$ & $0843 \mathrm{E}$ & Copper, Lead, Sulfur & Hydrothermal & Kirkham and Rafer, 2003. \\
\hline Stjernoy & Norway & $7018 \mathrm{~N}$ & $2241 \mathrm{E}$ & $\begin{array}{l}\text { Rare Earth Elements, Phosphate, } \\
\text { Barium, Strontium }\end{array}$ & Igneous & Olerud, 1993. \\
\hline Tellnes & Norway & $5820 \mathrm{~N}$ & $0625 \mathrm{E}$ & Titanium, Iron, Nickel, Copper & Igneous & McFaul and others, 2000. \\
\hline Borzecin/Sulmierzyce & Poland & $5134 \mathrm{~N}$ & $17015 \mathrm{E}$ & Copper, Silver, Zinc, Lead, Gold & Sedimentary & Kirkham and Rafer, 2003. \\
\hline Bytom District & Poland & $5013 \mathrm{~N}$ & $1900 \mathrm{E}$ & Lead, Zinc & Sedimentary & Lode, 2003. \\
\hline Lubin & Poland & $5135 \mathrm{~N}$ & $166 \mathrm{E}$ & $\begin{array}{l}\text { Copper, Lead, Zinc, Silver, Cobalt, } \\
\text { Molybdenum }\end{array}$ & Sedimentary & Lode, 2003. \\
\hline Myskow & Poland & $5137 \mathrm{~N}$ & $19022 \mathrm{E}$ & Copper, Molybdenum & Hydrothermal & Singer and others, 2002. \\
\hline Aljustrel & Portugal & $3754 \mathrm{~N}$ & $0815 \mathrm{~W}$ & Zinc, Lead, Copper & Hydrothermal & Lode, 2003. \\
\hline Guarda & Portugal & $4030 \mathrm{~N}$ & $0720 \mathrm{~W}$ & Lithium & Hydrothermal & McFaul and others, 2000. \\
\hline Nueves-Corvo & Portugal & $3732 \mathrm{~N}$ & $0758 \mathrm{~W}$ & Zinc, Copper, Lead, Tin & Hydrothermal & Lode, 2003. \\
\hline Panasqueira & Portugal & $4010 \mathrm{~N}$ & $0733 \mathrm{~W}$ & Copper, Tin, Tungsten & Hydrothermal & Lode, 2003. \\
\hline Apuseni District & Romania & $4618 \mathrm{~N}$ & $2318 \mathrm{E}$ & Copper, Gold, Silver, Molybdenum & Hydrothermal & Lode, 2003. \\
\hline
\end{tabular}


Table 2A. Mineral deposit name, location, principal commodities, type, and reference for the major metallic mineral deposits in Greenland, Europe, Russia, and Northern Central Asia. Table includes some duplications because of variable transliteration methods. Transliterations of names according to source reference.

\begin{tabular}{|c|c|c|c|c|c|c|}
\hline Deposit Name & Country & Latitude & Longitude & Commodities & Deposit Type & Reference \\
\hline Baia de Fier & Romania & $4514 \mathrm{~N}$ & $2345 \mathrm{E}$ & Graphite & Metamorphic & Krauss and others, 1989. \\
\hline Baia Mare District & Romania & $4741 \mathrm{~N}$ & $2353 \mathrm{E}$ & Lead, Zinc, Gold & Hydrothermal & Lode, 2003. \\
\hline Chituc & Romania & $4500 \mathrm{~N}$ & $2938 \mathrm{E}$ & Titanium, Zirconium & Surficial & Towner and others, 1988. \\
\hline Glogova-Sisesti District & Romania & $4455 \mathrm{~N}$ & $2258 \mathrm{E}$ & $\begin{array}{l}\text { Titanium, Zirconium, Garnet, Rare } \\
\text { Earth Elements }\end{array}$ & Igneous & Towner and others, 1988. \\
\hline Palazu Mare & Romania & $4413 \mathrm{~N}$ & $2837 \mathrm{E}$ & Iron & Sedimentary & Kirkham and Rafwe, 2003. \\
\hline Abakanskoye & Russia & $522500 \mathrm{~N}$ & $9002 \mathrm{E}$ & Iron & Hydrothermal & Ariunbileg and others, 2003. \\
\hline Adychan & Russia & $664202 \mathrm{~N}$ & $1372859 \mathrm{E}$ & Gold & Surficial & Ariunbileg and others, 2003. \\
\hline Aginskoe & Russia & $553037 \mathrm{~N}$ & $1575154 \mathrm{E}$ & Gold, Silver, Telleurium & Hydrothermal & Nokleberg and others, 1997. \\
\hline Agylkinskoe & Russia & $642242 \mathrm{~N}$ & $1365822 \mathrm{E}$ & Tungsten, Copper & Hydrothermal & Nokleberg and others, 1997. \\
\hline Agyndja & Russia & $651256 \mathrm{~N}$ & $1480158 \mathrm{E}$ & Copper & Sedimentary & Nokleberg and others, 1997. \\
\hline Aksakovskaya & Russia & $5400 \mathrm{~N}$ & $5414 \mathrm{E}$ & Copper & Sedimentary & Cox and others, 2003. \\
\hline Aksug & Russia & $5326 \mathrm{~N}$ & $9640 \mathrm{E}$ & Copper & Igneous & Singer and others, 2002. \\
\hline Aktashskoye & Russia & $501200 \mathrm{~N}$ & $871200 \mathrm{E}$ & Mercury & Hydrothermal & Ariunbileg and others, 2003. \\
\hline Aktogajskoe & Russia & $412843 \mathrm{~N}$ & $471740 \mathrm{E}$ & Aluminium & Sedimentary & Natapov and others, 2000. \\
\hline Aleksandrovka Suite & Russia & $570 \mathrm{~N}$ & $1200 \mathrm{E}$ & Copper & Sedimentary & Cox and others, 2003. \\
\hline Alexii-Olginsky Log & Russia & $58546 \mathrm{~N}$ & $594223 \mathrm{E}$ & Platinum & Surficial & McFaul and others, 2000. \\
\hline Algama & Russia & $5840 \mathrm{~N}$ & $13529 \mathrm{E}$ & Zirconium & Hydrothermal & Ariunbileg and others, 2003. \\
\hline Aliskerov & Russia & $674514 \mathrm{~N}$ & $1675050 \mathrm{E}$ & Gold & Surficial & Nokleberg and others, 1997. \\
\hline Allakh-Yun & Russia & $610030 \mathrm{~N}$ & $1380855 \mathrm{E}$ & Gold & Surficial & Ariunbileg and others, 2003. \\
\hline Ametistovoe & Russia & $612625 \mathrm{~N}$ & $164400 \mathrm{E}$ & Gold, Silver & Hydrothermal & Nokleberg and others, 1997. \\
\hline Ariadnoe & Russia & $451231 \mathrm{~N}$ & $1342745 \mathrm{E}$ & Titanium, Platinum & Igneous & Ariunbileg and others, 2003. \\
\hline Arsenyevsky & Russia & $442526 \mathrm{~N}$ & $1344714 \mathrm{E}$ & Tin, Lead, Zinc, Tungsten, Silver & Hydrothermal & Ariunbileg and others, 2003. \\
\hline Asachinskoe & Russia & $522445 \mathrm{~N}$ & $1575046 \mathrm{E}$ & Gold, Silver, Selenium & Hydrothermal & Nokleberg and others, 1997. \\
\hline Badran-Bezvodnyj & Russia & $641737 \mathrm{~N}$ & $141172 \mathrm{E}$ & Gold & Surficial & Natapov and others, 2000. \\
\hline Bakcharskoye & Russia & $563230 \mathrm{~N}$ & $821230 \mathrm{E}$ & Iron, Vanadium & Sedimentary & Ariunbileg and others, 2003. \\
\hline Balcan (Balkan) & Russia & $53270 \mathrm{~N}$ & $59360 \mathrm{E}$ & Tungsten & Hydrothermal & McFaul and others, 2000. \\
\hline
\end{tabular}


Table 2A. Mineral deposit name, location, principal commodities, type, and reference for the major metallic mineral deposits in Greenland, Europe, Russia, and Northern Central Asia. Table includes some duplications because of variable transliteration methods. Transliterations of names according to source reference.

\begin{tabular}{|c|c|c|c|c|c|c|}
\hline Deposit Name & Country & Latitude & Longitude & Commodities & Deposit Type & Reference \\
\hline Baley & Russia & $51380 \mathrm{~N}$ & $116360 \mathrm{E}$ & Gold & Hydrothermal & Kirkham and Rafer, 2003. \\
\hline Barandatskoye & Russia & $554700 \mathrm{~N}$ & $8912 \mathrm{E}$ & Iron & Sedimentary & Ariunbileg and others, 2003. \\
\hline Barun-Shiveinsky & Russia & $5122 \mathrm{~N}$ & $11510 \mathrm{E}$ & Tungsten, Mercury, Antimony & Hydrothermal & Ariunbileg and others, 2003. \\
\hline Baza & Russia & $5340 \mathrm{~N}$ & $9648 \mathrm{E}$ & Copper & Sedimentary & Cox and others, 2003. \\
\hline Bedoba River & Russia & $5850 \mathrm{~N}$ & $9715 \mathrm{E}$ & Copper & Sedimentary & Cox and others, 2003. \\
\hline Belebey & Russia & $5405 \mathrm{~N}$ & $5407 \mathrm{E}$ & Copper & Sedimentary & Cox and others, 2003. \\
\hline Belogorskoe & Russia & $642227 \mathrm{~N}$ & $911134 \mathrm{E}$ & $\begin{array}{l}\text { Tantalum, Tin, Niobium, Beryllium, } \\
\text { Lithium }\end{array}$ & Igneous & Seltmann and others, 2003. \\
\hline Beloretskoye & Russia & $510100 \mathrm{~N}$ & $8230 \mathrm{E}$ & Iron & Hydrothermal & Ariunbileg and others, 2003. \\
\hline Belukha (Bulucha) & Russia & $5030 \mathrm{~N}$ & $11600 \mathrm{E}$ & Tungsten & Hydrothermal & McFaul and others, 2000. \\
\hline Berezitovoe & Russia & $5419 \mathrm{~N}$ & $12235 \mathrm{E}$ & Zinc, Lead, Gold, Silver & Hydrothermal & Ariunbileg and others, 2003. \\
\hline Berezovsk & Russia & $5751 \mathrm{~N}$ & $6044 \mathrm{E}$ & Gold & Hydrothermal & Herrington, 2004. \\
\hline Bilyakchan & Russia & $5845 \mathrm{~N}$ & $1390 \mathrm{E}$ & Copper & Sedimentary & Cox and others, 2003. \\
\hline Birgildinskoe & Russia & $5508 \mathrm{~N}$ & $6107 \mathrm{E}$ & Copper & Igneous & Singer and others, 2002. \\
\hline $\begin{array}{l}\text { Blagoveshchensk-Svobodn } \\
\text { ensky district }\end{array}$ & Russia & $5050 \mathrm{~N}$ & $12725 \mathrm{E}$ & Gold & Surficial & Ariunbileg and others, 2003. \\
\hline Bodajbo & Russia & $575550 \mathrm{~N}$ & $1141442 \mathrm{E}$ & Gold & Surficial & Natapov and others, 2000. \\
\hline Boguchanskoe & Russia & $48552 \mathrm{~N}$ & $130409 \mathrm{E}$ & Tungsten, Tin & Hydrothermal & Ariunbileg and others, 2003. \\
\hline $\begin{array}{l}\text { Bom-Gorkhon } \\
\text { (Bomgorkhon) }\end{array}$ & Russia & $518 \mathrm{~N}$ & $10925 \mathrm{E}$ & Tungsten & Hydrothermal & McFaul and others, 2000. \\
\hline Bryansk Rapids & Russia & $5530 \mathrm{~N}$ & $10345 \mathrm{E}$ & Copper & Sedimentary & Cox and others, 2003. \\
\hline Bugdainskoe & Russia & $511036 \mathrm{~N}$ & $1174039 \mathrm{E}$ & Molybdenum & Igneous & Natapov and others, 2000. \\
\hline Bugulma & Russia & $5432 \mathrm{~N}$ & $5246 \mathrm{E}$ & Copper & Sedimentary & Cox and others, 2003. \\
\hline Bukuka & Russia & $510 \mathrm{~N}$ & $11650 \mathrm{E}$ & Tungsten & Hydrothermal & McFaul and others, 2000. \\
\hline Burindinskoe & Russia & $5341 \mathrm{~N}$ & $12454 \mathrm{E}$ & Gold, Silver & Hydrothermal & Ariunbileg and others, 2003. \\
\hline Burpala & Russia & $5630 \mathrm{~N}$ & $11500 \mathrm{E}$ & Copper & Sedimentary & Cox and others, 2003. \\
\hline Butun & Russia & $5500 \mathrm{~N}$ & $11600 \mathrm{E}$ & Copper & Sedimentary & Cox and others, 2003. \\
\hline Chepak & Russia & $630440 \mathrm{~N}$ & $1524452 \mathrm{E}$ & Gold, Tungsten, Bismuth & Igneous & Nokleberg and others, 1997. \\
\hline
\end{tabular}


Table 2A. Mineral deposit name, location, principal commodities, type, and reference for the major metallic mineral deposits in Greenland, Europe, Russia, and Northern Central Asia. Table includes some duplications because of variable transliteration methods. Transliterations of names according to source reference.

\begin{tabular}{|c|c|c|c|c|c|c|}
\hline Deposit Name & Country & Latitude & Longitude & Commodities & Deposit Type & Reference \\
\hline Chernorechenskaya & Russia & $6815 \mathrm{~N}$ & $8715 \mathrm{E}$ & Copper & Sedimentary & Cox and others, 2003. \\
\hline Dambuki & Russia & $5440 \mathrm{~N}$ & $12640 \mathrm{E}$ & Gold & Surficial & Ariunbileg and others, 2003. \\
\hline Darasunskoe & Russia & $522210 \mathrm{~N}$ & $1152954 \mathrm{E}$ & Gold & Hydrothermal & Natapov and others, 2000. \\
\hline Degtyarskoye & Russia & $5644 \mathrm{~N}$ & $6008 \mathrm{E}$ & $\begin{array}{l}\text { Copper, Zinc, Selenium, Telleurium, } \\
\text { Indium, Cadmium }\end{array}$ & Hydrothermal & Herrington, 2004. \\
\hline Deputatskoe & Russia & $69269 \mathrm{~N}$ & $1395055 \mathrm{E}$ & Tin & Hydrothermal & Nokleberg and others, 1997. \\
\hline Diturskoe & Russia & $484711 \mathrm{~N}$ & $131574 \mathrm{E}$ & Rare Earth Elements, Beryllium & Igneous & Ariunbileg and others, 2003. \\
\hline Dukat & Russia & $623606 \mathrm{~N}$ & $1551122 \mathrm{E}$ & Gold, Silver & Hydrothermal & Nokleberg and others, 1997. \\
\hline Dzhagdy & Russia & $5350 \mathrm{~N}$ & $13000 \mathrm{E}$ & Gold & Surficial & Ariunbileg and others, 2003. \\
\hline Dzhaninskoe & Russia & $553414 \mathrm{~N}$ & $134740 \mathrm{E}$ & Phosphorus, Titanium & Igneous & Ariunbileg and others, 2003. \\
\hline Dzhida & Russia & $5254 \mathrm{~N}$ & $10438 \mathrm{E}$ & Tungsten & Hydrothermal & McFaul and others, 2000. \\
\hline Dzhilinda (Mukhal'skoe) & Russia & $542020 \mathrm{~N}$ & $991015 \mathrm{E}$ & Aluminium & Igneous & Natapov and others, 2000. \\
\hline Eloguiskoye & Russia & $623200 \mathrm{~N}$ & $8551 \mathrm{E}$ & Iron & Igneous & Ariunbileg and others, 2003. \\
\hline Enashiminskoye 2 & Russia & $5929 \mathrm{~N}$ & $9228 \mathrm{E}$ & Iron & Hydrothermal & Ariunbileg and others, 2003. \\
\hline Esseiy 1 & Russia & $6916 \mathrm{~N}$ & $10215 \mathrm{E}$ & Iron, Titanium & Igneous & Ariunbileg and others, 2003. \\
\hline Federovo Sterlibasevo & Russia & $5330 \mathrm{~N}$ & $5505 \mathrm{E}$ & Copper & Sedimentary & Cox and others, 2003. \\
\hline Gai & Russia & $5128 \mathrm{~N}$ & $5829 \mathrm{E}$ & Copper, Zinc, Gold, Silver & Hydrothermal & Herrington, 2004. \\
\hline Galamskoe & Russia & $533811 \mathrm{~N}$ & $1335415 \mathrm{E}$ & Iron, Manganese, Phosphorus & Igneous & Ariunbileg and others, 2003. \\
\hline Galimovskoe & Russia & $622221 \mathrm{~N}$ & $1555607 \mathrm{E}$ & Tin, Silver & Hydrothermal & Natapov and others, 2000. \\
\hline Gerbikanskoe & Russia & $524640 \mathrm{~N}$ & $1315530 \mathrm{E}$ & Iron & Igneous & Ariunbileg and others, 2003. \\
\hline Gonzhinsky (Gonzha) & Russia & $5330 \mathrm{~N}$ & $12530 \mathrm{E}$ & Gold & Surficial & Ariunbileg and others, 2003. \\
\hline Gorevskoye & Russia & $5807 \mathrm{~N}$ & $9330 \mathrm{E}$ & Lead, Zinc & Igneous & Ariunbileg and others, 2003. \\
\hline Gornoye Ozero & Russia & $5955 \mathrm{~N}$ & $13704 \mathrm{E}$ & $\begin{array}{l}\text { Phosphorus, Niobium, Tantalum, } \\
\text { Rare Earth Elements }\end{array}$ & Igneous & Ariunbileg and others, 2003. \\
\hline Goroblagodatskoe & Russia & $581930 \mathrm{~N}$ & $595507 \mathrm{E}$ & Iron, Copper & Hydrothermal & Natapov and others, 2000. \\
\hline Graviisk & Russia & $6631 \mathrm{~N}$ & $8733 \mathrm{E}$ & Copper & Sedimentary & Cox and others, 2003. \\
\hline Gremjakha-Vyrmes Group & Russia & $684007 \mathrm{~N}$ & $322402 \mathrm{E}$ & Iron, Titanium, Apatite, Vanadium & Igneous & Natapov and others, 2000. \\
\hline
\end{tabular}


Table 2A. Mineral deposit name, location, principal commodities, type, and reference for the major metallic mineral deposits in Greenland, Europe, Russia, and Northern Central Asia. Table includes some duplications because of variable transliteration methods. Transliterations of names according to source reference.

\begin{tabular}{|c|c|c|c|c|c|c|}
\hline Deposit Name & Country & Latitude & Longitude & Commodities & Deposit Type & Reference \\
\hline Gulinskoye 1 & Russia & $7100 \mathrm{~N}$ & $10148 \mathrm{E}$ & Iron, Titanium & Igneous & Ariunbileg and others, 2003. \\
\hline Gusevogorsk & Russia & $5842 \mathrm{~N}$ & $5936 \mathrm{E}$ & Titanium, Iron & Igneous & Kirkham and Rafer, 2003. \\
\hline Igadei & Russia & $6530 \mathrm{~N}$ & $6030 \mathrm{E}$ & Copper & Sedimentary & Cox and others, 2003. \\
\hline Iliktinsk Suite & Russia & $5330 \mathrm{~N}$ & $10755 \mathrm{E}$ & Copper & Sedimentary & Cox and others, 2003. \\
\hline Irbinskoye & Russia & $5400 \mathrm{~N}$ & $9232 \mathrm{E}$ & Iron & Hydrothermal & Ariunbileg and others, 2003. \\
\hline Irkineeva River & Russia & $5930 \mathrm{~N}$ & $9815 \mathrm{E}$ & Copper & Sedimentary & Cox and others, 2003. \\
\hline Irkutsk Amphitheater & Russia & $5800 \mathrm{~N}$ & $10730 \mathrm{E}$ & Copper & Sedimentary & Cox and others, 2003. \\
\hline Iskinskoe (Askum) & Russia & $532430 \mathrm{~N}$ & $1402612 \mathrm{E}$ & Aluminium & Hydrothermal & Ariunbileg and others, 2003. \\
\hline Iultin & Russia & $675125 \mathrm{~N}$ & 1784336 & Tin, Tungsten & Hydrothermal & Nokleberg and others, 1997. \\
\hline Izluchinsk & Russia & $6736 \mathrm{~N}$ & $8645 \mathrm{E}$ & Copper & Sedimentary & Cox and others, 2003. \\
\hline Jaryshol & Russia & $5127 \mathrm{~N}$ & 88 09E & Iron & Hydrothermal & Ariunbileg and others, 2003. \\
\hline Jubileinoye & Russia & $5100 \mathrm{~N}$ & $8141 \mathrm{E}$ & Zinc, Lead, Copper & Hydrothermal & Ariunbileg and others, 2003. \\
\hline Julietta & Russia & $6110 \mathrm{~N}$ & $15359 \mathrm{E}$ & Gold, Silver & Hydrothermal & Nokleberg and others, 1997. \\
\hline Kachkanar & Russia & $5840 \mathrm{~N}$ & $5929 \mathrm{E}$ & Iron, Vanadium & Igneous & Kirkham and Rafer, 2003. \\
\hline Kalgutinskoye 1 & Russia & $4914 \mathrm{~N}$ & $8802 \mathrm{E}$ & Tungsten, Molybdenum & Hydrothermal & Ariunbileg and others, 2003. \\
\hline Kamo River & Russia & $6030 \mathrm{~N}$ & $9730 \mathrm{E}$ & Copper & Sedimentary & Cox and others, 2003. \\
\hline Kamyshenskiy Baikitik & Russia & $6133 \mathrm{~N}$ & $9309 \mathrm{E}$ & Iron & Hydrothermal & Ariunbileg and others, 2003. \\
\hline Kan-Taseyeva Basin & Russia & $5730 \mathrm{~N}$ & $9500 \mathrm{E}$ & Copper & Sedimentary & Cox and others, 2003. \\
\hline Kandrykul & Russia & $5525 \mathrm{~N}$ & $5300 \mathrm{E}$ & Copper & Sedimentary & Cox and others, 2003. \\
\hline Kapaevskoye 2 & Russia & $5831 \mathrm{~N}$ & $10345 \mathrm{E}$ & Iron & Hydrothermal & Ariunbileg and others, 2003. \\
\hline Karalveem & Russia & $681045 \mathrm{~N}$ & $1660914 \mathrm{E}$ & Gold, Tungsten & Hydrothermal & Nokleberg and others, 1997. \\
\hline Karamken & Russia & $60228 \mathrm{~N}$ & $1505053 \mathrm{E}$ & Gold, Silver & Hydrothermal & Nokleberg and others, 1997. \\
\hline Kargala & Russia & $5145 \mathrm{~N}$ & $5651 \mathrm{E}$ & Copper & Sedimentary & Cox and others, 2003. \\
\hline Katanga-Chadobets & Russia & $5930 \mathrm{~N}$ & $10045 \mathrm{E}$ & Copper & Sedimentary & Cox and others, 2003. \\
\hline Kavakta & Russia & $5553 \mathrm{~N}$ & $12522 \mathrm{E}$ & Phosphorus, Titanium, Iron & Igneous & Ariunbileg and others, 2003. \\
\hline Kazskoye & Russia & $5304 \mathrm{~N}$ & $8722 \mathrm{E}$ & Iron & Hydrothermal & Ariunbileg and others, 2003. \\
\hline Kazyngol & Russia & $5100 \mathrm{~N}$ & $9000 \mathrm{E}$ & Copper & Sedimentary & Cox and others, 2003. \\
\hline
\end{tabular}


Table 2A. Mineral deposit name, location, principal commodities, type, and reference for the major metallic mineral deposits in Greenland, Europe, Russia, and Northern Central Asia. Table includes some duplications because of variable transliteration methods. Transliterations of names according to source reference.

\begin{tabular}{|c|c|c|c|c|c|c|}
\hline Deposit Name & Country & Latitude & Longitude & Commodities & Deposit Type & Reference \\
\hline $\begin{array}{l}\text { Khakandzhinskoe } \\
\text { (Khakandzha) }\end{array}$ & Russia & $600135 \mathrm{~N}$ & $1423532 \mathrm{E}$ & Gold, Silver & Hydrothermal & Nokleberg and others, 1997. \\
\hline Kharlinskoye & Russia & $503215 \mathrm{~N}$ & $963500 \mathrm{E}$ & Aluminium & Igneous & Ariunbileg and others, 2003. \\
\hline Kharlovskoye & Russia & $51397 \mathrm{~N}$ & $825421 \mathrm{E}$ & Iron, Titanium, Vanadium & Igneous & Ariunbileg and others, 2003. \\
\hline Khibiny & Russia & $6752 \mathrm{~N}$ & $3335 \mathrm{E}$ & $\begin{array}{l}\text { Phosphate, Zirconium, Niobium, Rare } \\
\text { Earth Elements }\end{array}$ & Igneous & Kirkham and Rafer, 2003. \\
\hline Kholodninskoye & Russia & $5613 \mathrm{~N}$ & $10949 \mathrm{E}$ & Lead, Zinc & Igneous & Ariunbileg and others, 2003. \\
\hline Khotoidokh & Russia & $662650 \mathrm{~N}$ & $1410839 \mathrm{E}$ & $\begin{array}{l}\text { Lead, Zinc, Silver, Copper, Gold, } \\
\text { Barium }\end{array}$ & Hydrothermal & Ariunbileg and others, 2003. \\
\hline Kirov Region & Russia & $5820 \mathrm{~N}$ & $4950 \mathrm{E}$ & Copper & Sedimentary & Cox and others, 2003. \\
\hline Kirovskoe & Russia & $541900 \mathrm{~N}$ & $1242540 \mathrm{E}$ & Gold & Igneous & Ariunbileg and others, 2003. \\
\hline Kiyalykh-uzen & Russia & $5403 \mathrm{~N}$ & $8934 \mathrm{E}$ & Copper & Igneous & Singer and others, 2002. \\
\hline Kolpashevskoye & Russia & $573937 \mathrm{~N}$ & $824424 \mathrm{E}$ & Iron, Vanadium & Sedimentary & Ariunbileg and others, 2003. \\
\hline Kondyor & Russia & $573244 \mathrm{~N}$ & $1343755 \mathrm{E}$ & Platinum & Igneous & Ariunbileg and others, 2003. \\
\hline Korbalihinskoye & Russia & $511105 \mathrm{~N}$ & $821300 \mathrm{E}$ & Zinc, Lead, Copper & Hydrothermal & Ariunbileg and others, 2003. \\
\hline Kostamuksha & Russia & $6443 \mathrm{~N}$ & $3030 \mathrm{E}$ & Iron & Sedimentary & Kirkham and Rafer, 2003. \\
\hline Kovdor & Russia & $6734 \mathrm{~N}$ & $3024 \mathrm{E}$ & Iron, Phosphate & Igneous & Troitsky and others, 1998 \\
\hline $\begin{array}{l}\text { Krasnaja Shapochka, } \\
\text { Severnoe }\end{array}$ & Russia & $600951 \mathrm{~N}$ & $595732 \mathrm{E}$ & Aluminium & Sedimentary & Natapov and others, 2000. \\
\hline Krasnogorskoe & Russia & $482152 \mathrm{~N}$ & $142730 \mathrm{E}$ & Copper & Igneous & Singer and others, 2002. \\
\hline Krasnoye & Russia & $5730 \mathrm{~N}$ & $12100 \mathrm{E}$ & Copper & Sedimentary & Cox and others, 2003. \\
\hline Kti-Teberda & Russia & $43270 \mathrm{~N}$ & $41280 \mathrm{E}$ & Tungsten & Hydrothermal & McFaul and others, 2000. \\
\hline Kubaka & Russia & $635111 \mathrm{~N}$ & $1600226 \mathrm{E}$ & Gold, Silver & Hydrothermal & Kirkham and Rafer, 2003. \\
\hline Kukenei & Russia & $690748 \mathrm{~N}$ & $1740527 \mathrm{E}$ & Tin, Silver, Copper, Lead & Hydrothermal & Nokleberg and others, 1997. \\
\hline Kumroch & Russia & $553952 \mathrm{~N}$ & $1610953 \mathrm{E}$ & Gold, Silver, Copper, Lead, Zinc & Hydrothermal & Nokleberg and others, 1997. \\
\hline Kunarev & Russia & $632406 \mathrm{~N}$ & $1505522 \mathrm{E}$ & Lead, Zinc, Copper, Silver & Hydrothermal & Nokleberg and others, 1997. \\
\hline Kupol'noe & Russia & $633123 \mathrm{~N}$ & $1442816 \mathrm{E}$ & Silver, Tin & Igneous & Natapov and others, 2000. \\
\hline Kurpandzha & Russia & $633124 \mathrm{~N}$ & $1370059 \mathrm{E}$ & Copper & Sedimentary & Ariunbileg and others, 2003. \\
\hline
\end{tabular}


Table 2A. Mineral deposit name, location, principal commodities, type, and reference for the major metallic mineral deposits in Greenland, Europe, Russia, and Northern Central Asia. Table includes some duplications because of variable transliteration methods. Transliterations of names according to source reference.

\begin{tabular}{|c|c|c|c|c|c|c|}
\hline Deposit Name & Country & Latitude & Longitude & Commodities & Deposit Type & Reference \\
\hline $\begin{array}{l}\text { Kurun-Agalyk, Njuchcha, } \\
\text { Nera, Zenit }\end{array}$ & Russia & $643345 \mathrm{~N}$ & $144240 \mathrm{E}$ & Gold & Surficial & Natapov and others, 2000. \\
\hline Kurun-Uryakh & Russia & $583701 \mathrm{~N}$ & $1371102 \mathrm{E}$ & Gold & Surficial & Ariunbileg and others, 2003. \\
\hline Kyuchyus & Russia & $694757 \mathrm{~N}$ & $1344516 \mathrm{E}$ & Gold, Mercury, Antimony & Hydrothermal & Ariunbileg and others, 2003. \\
\hline Kyzyk-Chadr & Russia & $5256 \mathrm{~N}$ & $9647 \mathrm{E}$ & Copper & Igneous & Singer and others, 2002. \\
\hline Laba & Russia & $4439 \mathrm{~N}$ & $4044 \mathrm{E}$ & Manganese & Sedimentary & Kirkham and Rafer, 2003. \\
\hline Lavrenovskoye & Russia & $5409 \mathrm{~N}$ & $8816 \mathrm{E}$ & Iron & Hydrothermal & Ariunbileg and others, 2003. \\
\hline Lazurskoye & Russia & $5106 \mathrm{~N}$ & $8225 \mathrm{E}$ & Lead, Zinc & Hydrothermal & Ariunbileg and others, 2003. \\
\hline Lebedinskoe 2 & Russia & $605415 \mathrm{~N}$ & $1024113 \mathrm{E}$ & Gold & Hydrothermal & Natapov and others, 2000. \\
\hline Lednikovy-Sarmaka & Russia & $5234 \mathrm{~N}$ & $13441 \mathrm{E}$ & Tungsten, Copper & Hydrothermal & Ariunbileg and others, 2003. \\
\hline Lekyntelbei & Russia & $6752 \mathrm{~N}$ & $6620 \mathrm{E}$ & Copper, Molybdenum & Igneous & Singer and others, 2002. \\
\hline Lena & Russia & $600921 \mathrm{~N}$ & $1140524 \mathrm{E}$ & Copper & Sedimentary & Cox and others, 2003. \\
\hline Lendakhskoye & Russia & $5908 \mathrm{~N}$ & $9333 \mathrm{E}$ & Iron & Hydrothermal & Ariunbileg and others, 2003. \\
\hline Lermontovsky & Russia & $465644 \mathrm{~N}$ & $1342724 \mathrm{E}$ & Tungsten, Gold & Hydrothermal & Ariunbileg and others, 2003. \\
\hline Levoberezhnoye & Russia & $583530 \mathrm{~N}$ & $982200 \mathrm{E}$ & Iron & Hydrothermal & Ariunbileg and others, 2003. \\
\hline Log No. 7 & Russia & $584559 \mathrm{~N}$ & $592821 \mathrm{E}$ & Platinum, Gold & Surficial & McFaul and others, 2000. \\
\hline Lovozero & Russia & $6747 \mathrm{~N}$ & $3445 \mathrm{E}$ & $\begin{array}{l}\text { Rare Earth Elements, Tantalum, } \\
\text { Beryllium }\end{array}$ & Igneous & Kirkham and Rafer, 2003. \\
\hline Lunnoe 1 & Russia & $6323 \mathrm{~N}$ & $15512 \mathrm{E}$ & Silver, Gold & Hydrothermal & Kirkham and Rafer, 2003. \\
\hline Magnitogorsk district & Russia & $5325 \mathrm{~N}$ & $5909 \mathrm{E}$ & Iron, Cobalt & Hydrothermal & Herrington, 2004. \\
\hline Maimakanskoe & Russia & $553711 \mathrm{~N}$ & $1342942 \mathrm{E}$ & Titanium, Phosphorus & Igneous & Ariunbileg and others, 2003. \\
\hline Maiskoe & Russia & $690222 \mathrm{~N}$ & $1734346 \mathrm{E}$ & Gold, Arsenic, Antimony, Silver & Hydrothermal & Nokleberg and others, 1997. \\
\hline Malaia Prostokischenka & Russia & $584939 \mathrm{~N}$ & $592506 \mathrm{E}$ & Platinum, Gold & Surficial & McFaul and others, 2000. \\
\hline Malokhingansky district & Russia & $4910 \mathrm{~N}$ & $13055 \mathrm{E}$ & Gold & Surficial & Ariunbileg and others, 2003. \\
\hline Malokos & Russia & $5345 \mathrm{~N}$ & $10800 \mathrm{E}$ & Copper & Sedimentary & Cox and others, 2003. \\
\hline Malomyr & Russia & $53718 \mathrm{~N}$ & $1313056 \mathrm{E}$ & Gold & Hydrothermal & Ariunbileg and others, 2003. \\
\hline Mangazeika 1 & Russia & $654607 \mathrm{~N}$ & $1303440 \mathrm{E}$ & Lead, Silver, Zinc & Hydrothermal & Ariunbileg and others, 2003. \\
\hline
\end{tabular}


Table 2A. Mineral deposit name, location, principal commodities, type, and reference for the major metallic mineral deposits in Greenland, Europe, Russia, and Northern Central Asia. Table includes some duplications because of variable transliteration methods. Transliterations of names according to source reference.

\begin{tabular}{|c|c|c|c|c|c|c|}
\hline Deposit Name & Country & Latitude & Longitude & Commodities & Deposit Type & Reference \\
\hline Mikhailovsky & Russia & $5218 \mathrm{~N}$ & $3523 \mathrm{E}$ & Iron & Sedimentary & Kirkham and Rafer, 2003. \\
\hline Monchegorsk & Russia & $6753 \mathrm{~N}$ & $3250 \mathrm{E}$ & Nickel, Copper & Igneous & Kirkham and Rafer, 2003. \\
\hline Mount Sauri Pe & Russia & $6800 \mathrm{~N}$ & $6650 \mathrm{E}$ & Copper & Sedimentary & Cox and others, 2003. \\
\hline Nakhtandjin (Lora) & Russia & $592441 \mathrm{~N}$ & $1532849 \mathrm{E}$ & Copper, Molybdenum & Igneous & Nokleberg and others, 1997. \\
\hline Naminga Suite & Russia & $5600 \mathrm{~N}$ & $11700 \mathrm{E}$ & Copper & Sedimentary & Cox and others, 2003. \\
\hline Natalka & Russia & $613922 \mathrm{~N}$ & $1474104 \mathrm{E}$ & Gold & Hydrothermal & Nokleberg and others, 1997. \\
\hline Nerjundinskoye & Russia & $5850 \mathrm{~N}$ & $10348 \mathrm{E}$ & Iron & Hydrothermal & Ariunbileg and others, 2003. \\
\hline Netchen-Khaya & Russia & $614214 \mathrm{~N}$ & $1513215 \mathrm{E}$ & Gold, Molybdenum, Bismuth & Igneous & Nokleberg and others, 1997. \\
\hline Nezhdaninka & Russia & $623341 \mathrm{~N}$ & $1391834 \mathrm{E}$ & Gold, Silver & Hydrothermal & Ariunbileg and others, 2003. \\
\hline Niasma River & Russia & $585717 \mathrm{~N}$ & $593558 \mathrm{E}$ & Platinum, Gold & Surficial & McFaul and others, 2000. \\
\hline Nidysei Syncline & Russia & $6515 \mathrm{~N}$ & $6000 \mathrm{E}$ & Copper & Sedimentary & Cox and others, 2003. \\
\hline Nizhne-Angarskoye & Russia & $5816 \mathrm{~N}$ & $9433 \mathrm{E}$ & Iron & Sedimentary & Ariunbileg and others, 2003. \\
\hline Nizhne-Kjuchusskoe & Russia & $694618 \mathrm{~N}$ & $1344542 \mathrm{E}$ & Gold, Antimony, Mercury & Hydrothermal & Natapov and others, 2000. \\
\hline Nizhne-Lakur-skoye 1 & Russia & $6001 \mathrm{~N}$ & $10133 \mathrm{E}$ & Iron & Hydrothermal & Ariunbileg and others, 2003. \\
\hline Nizhnenyukzinsky district & Russia & $5628 \mathrm{~N}$ & $12201 \mathrm{E}$ & Gold & Surficial & Ariunbileg and others, 2003. \\
\hline Noril'sk-Talnakh & Russia & $6920 \mathrm{~N}$ & $8806 \mathrm{E}$ & $\begin{array}{l}\text { Platinum Group Elements, Nickel, } \\
\text { Copper, Cobalt, Gold }\end{array}$ & Igneous & Kirkham and Rafer, 2003. \\
\hline Novonikolaevsk & Russia & $5314 \mathrm{~N}$ & $6034 \mathrm{E}$ & Copper & Igneous & Singer and others, 2002. \\
\hline Odinochnoye & Russia & $5412 \mathrm{~N}$ & $9305 \mathrm{E}$ & Iron & Hydrothermal & Ariunbileg and others, 2003. \\
\hline Okhotsk & Russia & $594421 \mathrm{~N}$ & $1432634 \mathrm{E}$ & Gold & Surficial & Ariunbileg and others, 2003. \\
\hline Olcha & Russia & $645652 \mathrm{~N}$ & $1562628 \mathrm{E}$ & $\begin{array}{l}\text { Gold, Silver, Mercury, Copper, } \\
\text { Molybdenum }\end{array}$ & Hydrothermal & Nokleberg and others, 1997. \\
\hline Olekma Branch & Russia & $5720 \mathrm{~N}$ & $11955 \mathrm{E}$ & Copper & Sedimentary & Cox and others, 2003. \\
\hline Olenegorskoye & Russia & $6816 \mathrm{~N}$ & $335 \mathrm{E}$ & Iron & Sedimentary & Kirkham and Rafer, 2003. \\
\hline Olympiada & Russia & $595200 \mathrm{~N}$ & $9253 \mathrm{E}$ & Gold, Antimony & Sedimentary & Safonov, 1997. \\
\hline Organovskoye & Russia & $6100 \mathrm{~N}$ & $9225 \mathrm{E}$ & Iron & Hydrothermal & Ariunbileg and others, 2003. \\
\hline Orlovskoe & Russia & $510244 \mathrm{~N}$ & $1144423 \mathrm{E}$ & Copper, Zinc & Hydrothermal & Seltmann and others, 2003. \\
\hline
\end{tabular}


Table 2A. Mineral deposit name, location, principal commodities, type, and reference for the major metallic mineral deposits in Greenland, Europe, Russia, and Northern Central Asia. Table includes some duplications because of variable transliteration methods. Transliterations of names according to source reference.

\begin{tabular}{|c|c|c|c|c|c|c|}
\hline Deposit Name & Country & Latitude & Longitude & Commodities & Deposit Type & Reference \\
\hline Osennee & Russia & $502546 \mathrm{~N}$ & $1355559 \mathrm{E}$ & Copper, Molybdenum, Silver & Igneous & Singer and others, 2002. \\
\hline Pad-Yaga Musyur Range & Russia & $6730 \mathrm{~N}$ & $6530 \mathrm{E}$ & Copper & Sedimentary & Cox and others, 2003. \\
\hline Padyagin & Russia & $6700 \mathrm{~N}$ & $6500 \mathrm{E}$ & Copper & Sedimentary & Cox and others, 2003. \\
\hline Parabel-Chuzikskoye & Russia & $582704 \mathrm{~N}$ & $805415 \mathrm{E}$ & Iron, Vanadium & Sedimentary & Ariunbileg and others, 2003. \\
\hline Pavlik & Russia & $613559 \mathrm{~N}$ & $1474647 \mathrm{E}$ & Gold & Hydrothermal & Nokleberg and others, 1997. \\
\hline Pechenga & Russia & $6934 \mathrm{~N}$ & $3044 \mathrm{E}$ & $\begin{array}{l}\text { Nickel, Copper, Cobalt, Platinum } \\
\text { Group Elements }\end{array}$ & Igneous & Kirkham and Rafer, 2003. \\
\hline Perm Vyatka & Russia & $5630 \mathrm{~N}$ & $5045 \mathrm{E}$ & Copper & Sedimentary & Cox and others, 2003. \\
\hline Peschanka & Russia & $662158 \mathrm{~N}$ & 1643158 & Copper, Molybdenum, Gold, Silver & Igneous & Singer and others, 2002. \\
\hline Pikhtovoye & Russia & $5831 \mathrm{~N}$ & $9906 \mathrm{E}$ & Iron & Hydrothermal & Ariunbileg and others, 2003. \\
\hline Pioneer & Russia & $5327 \mathrm{~N}$ & $12627 \mathrm{E}$ & Gold & Igneous & Ariunbileg and others, 2003. \\
\hline Podolska & Russia & $5209 \mathrm{~N}$ & $5830 \mathrm{E}$ & Copper, Zinc, Lead, Gold, Silver & Hydrothermal & Herrington, 2004. \\
\hline Pokrovskoe & Russia & $532107 \mathrm{~N}$ & $1262151 \mathrm{E}$ & Gold, Silver & Hydrothermal & Ariunbileg and others, 2003. \\
\hline Prognoz & Russia & $654440 \mathrm{~N}$ & $1331208 \mathrm{E}$ & Silver, Lead & Hydrothermal & Ariunbileg and others, 2003. \\
\hline Pyrkakai & Russia & $693327 \mathrm{~N}$ & $1715701 \mathrm{E}$ & $\begin{array}{l}\text { Tin, Tungsten, Gold, Silver, Zinc, } \\
\text { Copper, Lead, Bismuth }\end{array}$ & Igneous & Nokleberg and others, 1997. \\
\hline Pyrkakai & Russia & $693327 \mathrm{~N}$ & $1715701 \mathrm{E}$ & $\begin{array}{l}\text { Tin, Tungsten, Gold, Silver, Zinc, } \\
\text { Copper, Lead, Bismuth }\end{array}$ & Igneous & Nokleberg and others, 1997. \\
\hline Rodnikovoe & Russia & $525025 \mathrm{~N}$ & $1581600 \mathrm{E}$ & Gold, Silver & Hydrothermal & Nokleberg and others, 1997. \\
\hline Rubtsovskoye & Russia & $5128 \mathrm{~N}$ & $8130 \mathrm{E}$ & Copper, Zinc, Lead & Hydrothermal & Ariunbileg and others, 2003. \\
\hline Rudnii & Russia & $6750 \mathrm{~N}$ & $8648 \mathrm{E}$ & Copper & Sedimentary & Cox and others, 2003. \\
\hline Safyanovska & Russia & $5713 \mathrm{~N}$ & $6119 \mathrm{E}$ & Zinc, Lead, Copper & Hydrothermal & Herrington, 2004. \\
\hline Sakmara & Russia & $5200 \mathrm{~N}$ & $5520 \mathrm{E}$ & Copper & Sedimentary & Cox and others, 2003. \\
\hline Salairskoye & Russia & $5414 \mathrm{~N}$ & $8547 \mathrm{E}$ & Lead, Zinc, Silver, Gold & Hydrothermal & Ariunbileg and others, 2003. \\
\hline Salavat & Russia & $5306 \mathrm{~N}$ & $5730 \mathrm{E}$ & Copper & Igneous & Singer and others, 2002. \\
\hline Salmysh & Russia & $5230 \mathrm{~N}$ & $5507 \mathrm{E}$ & Copper & Sedimentary & Cox and others, 2003. \\
\hline Sarylakhskoe & Russia & $642408 \mathrm{~N}$ & $1422431 \mathrm{E}$ & Gold, Antimony & Hydrothermal & Nokleberg and others, 1997. \\
\hline
\end{tabular}


Table 2A. Mineral deposit name, location, principal commodities, type, and reference for the major metallic mineral deposits in Greenland, Europe, Russia, and Northern Central Asia. Table includes some duplications because of variable transliteration methods. Transliterations of names according to source reference.

\begin{tabular}{|c|c|c|c|c|c|c|}
\hline Deposit Name & Country & Latitude & Longitude & Commodities & Deposit Type & Reference \\
\hline $\begin{array}{l}\text { Sebl'yavr Carbonatite } \\
\text { Complex (Seblyavr) }\end{array}$ & Russia & $6843 \mathrm{~N}$ & $3208 \mathrm{E}$ & Rare Earth Elements, Phosphate & Igneous & Kogarko and others, 1995. \\
\hline Sentachan & Russia & $662706 \mathrm{~N}$ & $1370308 \mathrm{E}$ & Gold, Antimony & Igneous & Natapov and others, 2000. \\
\hline Sheregesh & Russia & $5233 \mathrm{~N}$ & $8734 \mathrm{E}$ & Iron & Hydrothermal & Ariunbileg and others, 2003. \\
\hline Sherlovogorskoe & Russia & $503524 \mathrm{~N}$ & $116632 \mathrm{E}$ & Tin, Beryllium & Igneous & Natapov and others, 2000. \\
\hline Shkolnoe & Russia & $612732 \mathrm{~N}$ & $1484809 \mathrm{E}$ & Gold, Bismuth, Telleurium, Silver & Igneous & Nokleberg and others, 1997. \\
\hline Sibay & Russia & $5241 \mathrm{~N}$ & $5838 \mathrm{E}$ & Copper, Zinc, Lead, Gold, Silver & Hydrothermal & Herrington, 2004. \\
\hline Sinyukhinskoye & Russia & $5155 \mathrm{~N}$ & $8641 \mathrm{E}$ & Gold & Hydrothermal & Ariunbileg and others, 2003. \\
\hline Skalistoe & Russia & $542738 \mathrm{~N}$ & $1111622 \mathrm{E}$ & Copper & Igneous & Singer and others, 2002. \\
\hline Smirnovskoe & Russia & $444127 \mathrm{~N}$ & $1351620 \mathrm{E}$ & Molybdenum, Tungsten & Hydrothermal & Seltmann and others, 2003. \\
\hline Sokolovskoe & Russia & $562427 \mathrm{~N}$ & $955721 \mathrm{E}$ & Iron & Hydrothermal & Seltmann and others, 2003. \\
\hline Solovyevskii Log & Russia & $573827 \mathrm{~N}$ & $594747 \mathrm{E}$ & Platinum, Chromium & Surficial & McFaul and others, 2000. \\
\hline Sorskoe & Russia & $540047 \mathrm{~N}$ & $900739 \mathrm{E}$ & Molybdenum, Copper & Igneous & Natapov and others, 2000. \\
\hline South Muya Range & Russia & $5715 \mathrm{~N}$ & $11330 \mathrm{E}$ & Copper & Sedimentary & Cox and others, 2003. \\
\hline Sovetskoe & Russia & $602113 \mathrm{~N}$ & $930119 \mathrm{E}$ & Gold & Hydrothermal & Natapov and others, 2000. \\
\hline Srednee & Russia & $691915 \mathrm{~N}$ & $1451201 \mathrm{E}$ & Lead, Zinc & Hydrothermal & Ariunbileg and others, 2003. \\
\hline Srednenuykzhinsk & Russia & $5453 \mathrm{~N}$ & $12415 \mathrm{E}$ & Gold & Surficial & Ariunbileg and others, 2003. \\
\hline Stepanoff Log & Russia & $572756 \mathrm{~N}$ & $584800 \mathrm{E}$ & Platinum & Surficial & McFaul and others, 2000. \\
\hline Stepnoye & Russia & $5126 \mathrm{~N}$ & $8155 \mathrm{E}$ & Lead, Zinc & Hydrothermal & Ariunbileg and others, 2003. \\
\hline Sukharikha & Russia & $671559 \mathrm{~N}$ & $865553 \mathrm{E}$ & Copper & Sedimentary & Cox and others, 2003. \\
\hline Sukhoi Log & Russia & $5837 \mathrm{~N}$ & $11515 \mathrm{E}$ & Gold, Platinum & Hydrothermal & Kirkham and Rafer, 2003. \\
\hline Suringdakonskoye & Russia & $6322 \mathrm{~N}$ & $9116 \mathrm{E}$ & Iron & Hydrothermal & Ariunbileg and others, 2003. \\
\hline Susuman (Chai, Yuryuyen) & Russia & $624930 \mathrm{~N}$ & $1475139 \mathrm{E}$ & Gold & Surficial & Nokleberg and others, 1997. \\
\hline Svetloe & Russia & $582442 \mathrm{~N}$ & $116216 \mathrm{E}$ & Tin, Tungsten & Hydrothermal & Nokleberg and others, 1997. \\
\hline Tabratskoye & Russia & $532900 \mathrm{~N}$ & $940530 \mathrm{E}$ & Iron & Hydrothermal & Ariunbileg and others, 2003. \\
\hline Tagarskoye & Russia & $5827 \mathrm{~N}$ & $9908 \mathrm{E}$ & Iron & Hydrothermal & Ariunbileg and others, 2003. \\
\hline Tagul-Uda Rivers & Russia & $5400 \mathrm{~N}$ & $9800 \mathrm{E}$ & Copper & Sedimentary & Cox and others, 2003. \\
\hline
\end{tabular}


Table 2A. Mineral deposit name, location, principal commodities, type, and reference for the major metallic mineral deposits in Greenland, Europe, Russia, and Northern Central Asia. Table includes some duplications because of variable transliteration methods. Transliterations of names according to source reference.

\begin{tabular}{|c|c|c|c|c|c|c|}
\hline Deposit Name & Country & Latitude & Longitude & Commodities & Deposit Type & Reference \\
\hline Talovskoye & Russia & $5126 \mathrm{~N}$ & $8155 \mathrm{E}$ & Zinc, Lead, Copper & Hydrothermal & Ariunbileg and others, 2003. \\
\hline Tamvatney & Russia & $632844 \mathrm{~N}$ & $1741236 \mathrm{E}$ & Mercury, Tungsten, Arsenic & Hydrothermal & Nokleberg and others, 1997. \\
\hline Tarynnakh & Russia & $5819 \mathrm{~N}$ & $11917 \mathrm{E}$ & Iron, Gold & Sedimentary & Ariunbileg and others, 2003. \\
\hline Taseevskoe & Russia & $521459 \mathrm{~N}$ & $1130123 \mathrm{E}$ & Gold & Hydrothermal & Kirkham and Rafer, 2003. \\
\hline Tashtagol & Russia & $522730 \mathrm{~N}$ & $873300 \mathrm{E}$ & Iron, Cobalt & Hydrothermal & Ariunbileg and others, 2003. \\
\hline Tastygskoye & Russia & $4953 \mathrm{~N}$ & $9718 \mathrm{E}$ & $\begin{array}{l}\text { Lithium, Tantalum, Niobium, } \\
\text { Beryllium }\end{array}$ & Igneous & Ariunbileg and others, 2003. \\
\hline Tayginsk (Tajginskoje) & Russia & $5538 \mathrm{~N}$ & $6039 \mathrm{E}$ & Graphite & Metamorphic & McFaul and others, 2000. \\
\hline Tayozhnoe 2 & Russia & $5746 \mathrm{~N}$ & $12526 \mathrm{E}$ & Iron & Hydrothermal & Ariunbileg and others, 2003. \\
\hline Teiskoye & Russia & $531000 \mathrm{~N}$ & $892030 \mathrm{E}$ & Iron & Hydrothermal & Ariunbileg and others, 2003. \\
\hline Timofeevskoe & Russia & $5101 \mathrm{~N}$ & $8410 \mathrm{E}$ & Iron & Hydrothermal & Ariunbileg and others, 2003. \\
\hline Tokur & Russia & $530906 \mathrm{~N}$ & $1324929 \mathrm{E}$ & Gold & Hydrothermal & Ariunbileg and others, 2003. \\
\hline Tominskoe & Russia & $541257 \mathrm{~N}$ & $1425425 \mathrm{E}$ & Copper & Igneous & Singer and others, 2002. \\
\hline Tomtor & Russia & $7105 \mathrm{~N}$ & $11640 \mathrm{E}$ & $\begin{array}{l}\text { Niobium, Rare Earth Elements, } \\
\text { Phosphorus }\end{array}$ & Igneous & Ariunbileg and others, 2003. \\
\hline Tumannoe & Russia & $492239 \mathrm{~N}$ & $1314413 \mathrm{E}$ & Copper & Igneous & Singer and others, 2002. \\
\hline Turukhanskoye & Russia & $655100 \mathrm{~N}$ & $852630 \mathrm{E}$ & Iron & Igneous & Ariunbileg and others, 2003. \\
\hline Tustuzhul & Russia & $5300 \mathrm{~N}$ & $9400 \mathrm{E}$ & Copper & Sedimentary & Cox and others, 2003. \\
\hline Tyrnyauz & Russia & $453833 \mathrm{~N}$ & $454238 \mathrm{E}$ & Tungsten, Molybdenum & Hydrothermal & Kirkham and Rafer, 2003. \\
\hline Uchalinskoe, Uzel'ginskoe & Russia & $54755 \mathrm{~N}$ & $592331 \mathrm{E}$ & $\begin{array}{l}\text { Copper, Zinc, Lead, Gold, Silver, } \\
\text { Cadmium, Indium, Selenium, } \\
\text { Telleurium }\end{array}$ & Hydrothermal & Herrington, 2004. \\
\hline Udokan & Russia & $5630 \mathrm{~N}$ & $11810 \mathrm{E}$ & Copper & Sedimentary & Cox and others, 2003. \\
\hline Udorongovskoye & Russia & $582330 \mathrm{~N}$ & $943300 \mathrm{E}$ & Iron & Igneous & Ariunbileg and others, 2003. \\
\hline Ugui Graben & Russia & $5900 \mathrm{~N}$ & $11959 \mathrm{E}$ & Copper & Sedimentary & Cox and others, 2003. \\
\hline Urshak & Russia & $5355 \mathrm{~N}$ & $5455 \mathrm{E}$ & Copper & Sedimentary & Cox and others, 2003. \\
\hline Urskoye district & Russia & $5429 \mathrm{~N}$ & $8525 \mathrm{E}$ & Lead, Zinc, Copper & Hydrothermal & Ariunbileg and others, 2003. \\
\hline Urup Sandstone & Russia & $4342 \mathrm{~N}$ & $4058 \mathrm{E}$ & Copper & Sedimentary & Cox and others, 2003. \\
\hline
\end{tabular}


Table 2A. Mineral deposit name, location, principal commodities, type, and reference for the major metallic mineral deposits in Greenland, Europe, Russia, and Northern Central Asia. Table includes some duplications because of variable transliteration methods. Transliterations of names according to source reference.

\begin{tabular}{|c|c|c|c|c|c|c|}
\hline Deposit Name & Country & Latitude & Longitude & Commodities & Deposit Type & Reference \\
\hline Uzelga & Russia & $5411 \mathrm{~N}$ & $5915 \mathrm{E}$ & $\begin{array}{l}\text { Copper, Zinc, Gold, Silver, Cd, In, } \\
\text { Selenium, Telleurium }\end{array}$ & Hydrothermal & Herrington, 2004. \\
\hline Valkumei & Russia & $693902 \mathrm{~N}$ & $1701228 \mathrm{E}$ & Tin & Hydrothermal & Nokleberg and others, 1997. \\
\hline Vasilkovskoe & Russia & $675719 \mathrm{~N}$ & $54813 \mathrm{E}$ & Gold & Hydrothermal & Seltmann and others, 2003. \\
\hline Velmo River & Russia & $6045 \mathrm{~N}$ & $9230 \mathrm{E}$ & Copper & Sedimentary & Cox and others, 2003. \\
\hline Verkhne-Indigirsky & Russia & $5355 \mathrm{~N}$ & $12230 \mathrm{E}$ & Gold & Surficial & Ariunbileg and others, 2003. \\
\hline Verkhne-Ollonokonskoye & Russia & $593100 \mathrm{~N}$ & $960830 \mathrm{E}$ & Iron & Hydrothermal & Ariunbileg and others, 2003. \\
\hline Verkhne-Yansky & Russia & $5300 \mathrm{~N}$ & $13245 \mathrm{E}$ & Gold & Surficial & Ariunbileg and others, 2003. \\
\hline Verkhneamursk & Russia & $5355 \mathrm{~N}$ & $12230 \mathrm{E}$ & Gold & Surficial & Ariunbileg and others, 2003. \\
\hline Verkhneselemdzha 1 & Russia & $5300 \mathrm{~N}$ & $13245 \mathrm{E}$ & Gold & Surficial & Ariunbileg and others, 2003. \\
\hline Verkhneselemdzha 2 & Russia & $5540 \mathrm{~N}$ & $12500 \mathrm{E}$ & Gold & Surficial & Ariunbileg and others, 2003. \\
\hline Verkhnezeisk & Russia & $5455 \mathrm{~N}$ & $13105 \mathrm{E}$ & Gold & Surficial & Ariunbileg and others, 2003. \\
\hline Verkhny-Omolon & Russia & $632102 \mathrm{~N}$ & $1582201 \mathrm{E}$ & Iron & Sedimentary & Nokleberg and others, 1997. \\
\hline Vetrenskoe & Russia & $614440 \mathrm{~N}$ & $1493329 \mathrm{E}$ & Gold & Metamorphic & Nokleberg and others, 1997. \\
\hline Volkovskoe & Russia & $58731 \mathrm{~N}$ & $595022 \mathrm{E}$ & Copper, Iron, Lead, Vanadium & Igneous & McFaul and others, 2000. \\
\hline Vostok-2 & Russia & $463356 \mathrm{~N}$ & $1355116 \mathrm{E}$ & Tungsten & Hydrothermal & Ariunbileg and others, 2003. \\
\hline Voznesenskoe 1 & Russia & $5438 \mathrm{~N}$ & $5948 \mathrm{E}$ & Copper, Gold & Igneous & Singer and others, 2002. \\
\hline Vyasovka & Russia & $5147 \mathrm{~N}$ & $5551 \mathrm{E}$ & Copper & Sedimentary & Cox and others, 2003. \\
\hline Vysokogorskoe & Russia & $430000 \mathrm{~N}$ & $1350000 \mathrm{E}$ & Tin & Hydrothermal & Ariunbileg and others, 2003. \\
\hline Yaguzak & Russia & $5506 \mathrm{~N}$ & $6111 \mathrm{E}$ & Copper & Igneous & Singer and others, 2002. \\
\hline Yenisei Ridge & Russia & $5830 \mathrm{~N}$ & $9400 \mathrm{E}$ & Copper & Sedimentary & Cox and others, 2003. \\
\hline Yubileinoye 2 & Russia & $5100 \mathrm{~N}$ & $8141 \mathrm{E}$ & Zinc, Lead, Copper & Hydrothermal & Ariunbileg and others, 2003. \\
\hline Zacharovskoye & Russia & $5137 \mathrm{~N}$ & $8123 \mathrm{E}$ & Zinc, Lead, Copper & Hydrothermal & Ariunbileg and others, 2003. \\
\hline Zapadno-Paljanskoe & Russia & $685351 \mathrm{~N}$ & $1715924 \mathrm{E}$ & Mercury & Hydrothermal & Natapov and others, 2000. \\
\hline Zarechenskoye & Russia & $5111 \mathrm{~N}$ & $8206 \mathrm{E}$ & Gold, Lead, Zinc, Silver & Hydrothermal & Ariunbileg and others, 2003. \\
\hline Zeiya-Selemdzha & Russia & $5250 \mathrm{~N}$ & $12850 \mathrm{E}$ & Gold & Surficial & Ariunbileg and others, 2003. \\
\hline Zhirekenskoe & Russia & $524720 \mathrm{~N}$ & $1171909 \mathrm{E}$ & Molybdenum & Igneous & Natapov and others, 2000. \\
\hline
\end{tabular}


Table 2A. Mineral deposit name, location, principal commodities, type, and reference for the major metallic mineral deposits in Greenland, Europe, Russia, and Northern Central Asia. Table includes some duplications because of variable transliteration methods. Transliterations of names according to source reference.

\begin{tabular}{|c|c|c|c|c|c|c|}
\hline Deposit Name & Country & Latitude & Longitude & Commodities & Deposit Type & Reference \\
\hline Zmeinogorskoye & Russia & $5108 \mathrm{~N}$ & $8211 \mathrm{E}$ & Zinc, Lead, Copper, Gold & Hydrothermal & Ariunbileg and others, 2003. \\
\hline Bor-Majdanpek & $\begin{array}{l}\text { Serbia and } \\
\text { Montenegro }\end{array}$ & $4406 \mathrm{~N}$ & $2206 \mathrm{E}$ & Copper, Gold, Silver & Hydrothermal & Lode, 2003. \\
\hline Stari Trg & $\begin{array}{l}\text { Serbia and } \\
\text { Montenegro }\end{array}$ & $4256 \mathrm{~N}$ & $2056 \mathrm{E}$ & Lead, Zinc, Silver, Copper & Hydrothermal & McFaul and others, 2000. \\
\hline Trepca & $\begin{array}{l}\text { Serbia and } \\
\text { Montenegro }\end{array}$ & $4255 \mathrm{~N}$ & $2054 \mathrm{E}$ & Lead, Zinc, Silver & Hydrothermal & Lode, 2003. \\
\hline Hodrusa District & Slovakia & $4815 \mathrm{~N}$ & $18027 \mathrm{E}$ & Gold, Silver, Copper, Lead, Zinc & Hydrothermal & Lode, 2003. \\
\hline Ochtiná & Slovakia & $4841 \mathrm{~N}$ & $2020 \mathrm{E}$ & Magnesium & Hydrothermal & Harben and Kuzvart, 1996. \\
\hline Ratkovská Suchá & Slovakia & $4835 \mathrm{~N}$ & $2004 \mathrm{E}$ & Magnesium & Hydrothermal & Harben and Kuzvart, 1996. \\
\hline Rudnany & Slovakia & $4853 \mathrm{~N}$ & $2041 \mathrm{E}$ & Iron, Copper, Mercury, Barium & Hydrothermal & Hruska, 1991. \\
\hline Sirk & Slovakia & $4837 \mathrm{~N}$ & $2006 \mathrm{E}$ & Magnesium & Hydrothermal & Harben and Kuzvart, 1996. \\
\hline Idrija & Slovenia & $4600 \mathrm{~N}$ & $14015 \mathrm{E}$ & Mercury & Hydrothermal & Lode, 2003. \\
\hline Aguas Tenidas Este & Spain & $3747 \mathrm{~N}$ & $0650 \mathrm{~W}$ & Zinc, Lead, Copper & Hydrothermal & Lode, 2003. \\
\hline Almanden & Spain & $3847 \mathrm{~N}$ & $0451 \mathrm{~W}$ & Mercury & Hydrothermal & Lode, 2003. \\
\hline Almeria & Spain & $3650 \mathrm{~N}$ & $0227 \mathrm{~W}$ & $\begin{array}{l}\text { Lead, Zinc, Mercury, Copper, } \\
\text { Fluorine }\end{array}$ & Hydrothermal & McFaul and others, 2000. \\
\hline Aznalcollar & Spain & $3732 \mathrm{~N}$ & $0617 \mathrm{~W}$ & Lead, Zinc, Pyrite, Copper, Silver & Hydrothermal & McFaul and others, 2000. \\
\hline Cartagena & Spain & $3739 \mathrm{~N}$ & $0045 \mathrm{~W}$ & Lead, Zinc, Silver & Sedimentary & McFaul and others, 2000. \\
\hline El Valle-Boinas-Carles & Spain & $4318 \mathrm{~N}$ & $0619 \mathrm{~W}$ & Gold & Hydrothermal & Lode, 2003. \\
\hline Eugui & Spain & $4259 \mathrm{~N}$ & $0130 \mathrm{~W}$ & Magnesium & Hydrothermal & $\begin{array}{l}\text { Regueiro y Gonzalez-Barros, } \\
1995 .\end{array}$ \\
\hline Las Cruces & Spain & $3730 \mathrm{~N}$ & $0558 \mathrm{~W}$ & Copper, Zinc, Lead & Hydrothermal & Lode, 2003. \\
\hline Los Santos & Spain & $4032 \mathrm{~N}$ & $0546 \mathrm{~W}$ & Tungsten & Hydrothermal & Lode, 2003. \\
\hline Montevive & Spain & $3910 \mathrm{~N}$ & $0342 \mathrm{~W}$ & Strontium & Sedimentary & Harben and Kuzvart, 1996. \\
\hline Osor & Spain & $4159 \mathrm{~N}$ & $0249 \mathrm{E}$ & Lead, Zinc, Barium, Fluorine & Hydrothermal & McFaul and others, 2000. \\
\hline Reocin & Spain & $4321 \mathrm{~N}$ & $04056 \mathrm{~W}$ & Zinc, Lead & Sedimentary & Lode, 2003. \\
\hline Rio Tinto & Spain & $3742 \mathrm{~N}$ & $0636 \mathrm{~W}$ & Copper, Zinc, Gold, Lead & Hydrothermal & McFaul and others, 2000. \\
\hline Rubailes-Santa Barbara & Spain & $4240 \mathrm{~N}$ & $0656 \mathrm{~W}$ & Zinc, Lead, Silver & Sedimentary & Lode, 2003. \\
\hline
\end{tabular}


Table 2A. Mineral deposit name, location, principal commodities, type, and reference for the major metallic mineral deposits in Greenland, Europe, Russia, and Northern Central Asia. Table includes some duplications because of variable transliteration methods. Transliterations of names according to source reference.

\begin{tabular}{|c|c|c|c|c|c|c|}
\hline Deposit Name & Country & Latitude & Longitude & Commodities & Deposit Type & Reference \\
\hline Sotiel & Spain & $3736 \mathrm{~N}$ & $0651 \mathrm{~W}$ & Copper, Lead, Zinc, Pyrite & Hydrothermal & McFaul and others, 2000. \\
\hline Tierga & Spain & $4140 \mathrm{~N}$ & $0136 \mathrm{~W}$ & Iron & Sedimentary & Harben and Kuzvart, 1996 \\
\hline Aitik & Sweden & $6725 \mathrm{~N}$ & $2034 \mathrm{E}$ & Copper, Gold, Silver & Hydrothermal & Lode, 2003. \\
\hline Bjorkdal & Sweden & $6440 \mathrm{~N}$ & $2016 \mathrm{E}$ & Gold & Hydrothermal & McFaul and others, 2000. \\
\hline Boliden & Sweden & $6431 \mathrm{~N}$ & $2013 \mathrm{E}$ & $\begin{array}{l}\text { Copper, Gold, Zinc, Arsenic, Lead, } \\
\text { Silver }\end{array}$ & Hydrothermal & Lode, 2003. \\
\hline Falun & Sweden & $6021 \mathrm{~N}$ & $15022 \mathrm{E}$ & Zinc, Lead, Gold, Copper, Silver & Hydrothermal & Lode, 2003. \\
\hline Garpenberg & Sweden & $6019 \mathrm{~N}$ & $16010 \mathrm{E}$ & Zinc, Lead, Copper, Silver, Gold & Hydrothermal & McFaul and others, 2000. \\
\hline Kiruna & Sweden & $6730 \mathrm{~N}$ & $207 \mathrm{E}$ & Iron, Phosphate & Igneous & Lode, 2003. \\
\hline Laisvall & Sweden & $665 \mathrm{~N}$ & $1706 \mathrm{E}$ & Lead, Zinc, Silver & Hydrothermal & McFaul and others, 2000. \\
\hline Nygruvan, Knallagruvan & Sweden & $5849 \mathrm{~N}$ & $1506 \mathrm{E}$ & Zinc, Lead, Silver, Copper, Arsenic & Hydrothermal & McFaul and others, 2000. \\
\hline Storliden & Sweden & $6600 \mathrm{~N}$ & $2030 \mathrm{E}$ & Zinc, Copper, Gold, Silver & Hydrothermal & Wilburn, 2004. \\
\hline Yxsjoberg & Sweden & $6006 \mathrm{~N}$ & $1500 \mathrm{E}$ & Tungsten, Copper & Hydrothermal & Antony and others, 1998. \\
\hline Zinkgruven & Sweden & $5829 \mathrm{~N}$ & $15037 \mathrm{E}$ & Zinc, Lead, Silver & Hydrothermal & Lode, 2003. \\
\hline Aqarkhar & Tajikistan & $3756 \mathrm{~N}$ & $7344 \mathrm{E}$ & Tin, Copper, Lead & Igneous & Seltmann and others, 2003. \\
\hline Chore & Tajikistan & $392351 \mathrm{~N}$ & $683315 \mathrm{E}$ & Gold, Platinum, Palladium & Igneous & Natapov and others, 2000. \\
\hline Chorukh-Dairon & Tajikistan & $4024 \mathrm{~N}$ & $6942 \mathrm{E}$ & Tungsten, Molybdenum & Igneous & Seltmann and others, 2003. \\
\hline Dalnee & Tajikistan & $4047 \mathrm{~N}$ & $6940 \mathrm{E}$ & Molybdenum, Copper & Igneous & Seltmann and others, 2003. \\
\hline Dzhizhikrut & Tajikistan & $391215 \mathrm{~N}$ & $683602 \mathrm{E}$ & Mercury, Antimony & Hydrothermal & Natapov and others, 2000. \\
\hline Jakhsu & Tajikistan & $383448 \mathrm{~N}$ & $702419 \mathrm{E}$ & Gold & Surficial & Natapov and others, 2000. \\
\hline Jezhikrut & Tajikistan & $3909 \mathrm{~N}$ & $6839 \mathrm{E}$ & Antimony, Mercury & Hydrothermal & Seltmann and others, 2003. \\
\hline Jilau & Tajikistan & $3920 \mathrm{~N}$ & $6743 \mathrm{E}$ & Gold, Tungsten & Igneous & Seltmann and others, 2003. \\
\hline Ravnou & Tajikistan & $3824 \mathrm{~N}$ & $7028 \mathrm{E}$ & Copper & Sedimentary & Seltmann and others, 2003. \\
\hline Taror & Tajikistan & $39172 \mathrm{~N}$ & $675254 \mathrm{E}$ & Gold & Hydrothermal & Seltmann and others, 2003. \\
\hline Arikskoe & Turkmenistan & $375614 \mathrm{~N}$ & $65478 \mathrm{E}$ & Strontium & Sedimentary & Natapov and others, 2000. \\
\hline Central'no-Karakumskoe & Turkmenistan & $400923 \mathrm{~N}$ & $585746 \mathrm{E}$ & Strontium & Sedimentary & Natapov and others, 2000. \\
\hline Karashor & Turkmenistan & $410428 \mathrm{~N}$ & $563253 \mathrm{E}$ & Strontium & Sedimentary & Natapov and others, 2000. \\
\hline
\end{tabular}


Table 2A. Mineral deposit name, location, principal commodities, type, and reference for the major metallic mineral deposits in Greenland, Europe, Russia, and Northern Central Asia. Table includes some duplications because of variable transliteration methods. Transliterations of names according to source reference.

\begin{tabular}{|c|c|c|c|c|c|c|}
\hline Deposit Name & Country & Latitude & Longitude & Commodities & Deposit Type & Reference \\
\hline Artemovsk Basin & Ukraine & $4836 \mathrm{~N}$ & $3820 \mathrm{E}$ & Copper & Sedimentary & Cox and others, 2003. \\
\hline Azovske & Ukraine & $4535 \mathrm{~N}$ & $3434 \mathrm{E}$ & $\begin{array}{l}\text { Rare Earth Elements, Phosphorus, } \\
\text { Zirconium }\end{array}$ & Igneous & O'Driscoll, 1998. \\
\hline Bakhmut Basin & Ukraine & $4830 \mathrm{~N}$ & $3600 \mathrm{E}$ & Copper & Sedimentary & Cox and others, 2003. \\
\hline Belozerka & Ukraine & $4706 \mathrm{~N}$ & $3455 \mathrm{E}$ & Iron & Sedimentary & Kirkham and Rafer, 2003. \\
\hline Beregovo & Ukraine & $4820 \mathrm{~N}$ & $2237 \mathrm{E}$ & $\begin{array}{l}\text { Gold, Silver, Lead, Zinc, Mercury, } \\
\text { Antimony }\end{array}$ & Hydrothermal & Kirkham and Rafer, 2003. \\
\hline Bol'shoi Tokmak & Ukraine & $4730 \mathrm{~N}$ & $3540 \mathrm{E}$ & Manganese & Sedimentary & Kirkham and Rafer, 2003. \\
\hline Dnestr & Ukraine & $4830 \mathrm{~N}$ & $2700 \mathrm{E}$ & Copper & Sedimentary & Cox and others, 2003. \\
\hline Donbass & Ukraine & $4822 \mathrm{~N}$ & $3807 \mathrm{E}$ & Copper & Sedimentary & Cox and others, 2003. \\
\hline Kal Mius & Ukraine & $4730 \mathrm{~N}$ & $3730 \mathrm{E}$ & Copper & Sedimentary & Cox and others, 2003. \\
\hline Kremenchug & Ukraine & $491027 \mathrm{~N}$ & $333700 \mathrm{E}$ & Iron & Sedimentary & Kirkham and Rafer, 2003. \\
\hline Krivoy Rog & Ukraine & $4755 \mathrm{~N}$ & $3324 \mathrm{E}$ & Iron & Sedimentary & Kirkham and Rafer, 2003. \\
\hline Malyshevskiy & Ukraine & $4830 \mathrm{~N}$ & $3420 \mathrm{E}$ & Titanium, Zirconium & Surficial & Kirkham and Rafer, 2003. \\
\hline Nikolaevskoe & Ukraine & $473345 \mathrm{~N}$ & $373829 \mathrm{E}$ & Lead, Zinc, Silver & Hydrothermal & Ariunbileg and others, 2003. \\
\hline Nikopol & Ukraine & $4740 \mathrm{~N}$ & $3430 \mathrm{E}$ & Manganese & Surficial & Kirkham and Rafer, 2003. \\
\hline Oktjabr'skoe & Ukraine & $47311 \mathrm{~N}$ & $372624 \mathrm{E}$ & $\begin{array}{l}\text { Aluminium, Zirconium, Niobium, } \\
\text { Titanium, Iron }\end{array}$ & Igneous & Natapov and others, 2000. \\
\hline Yastrebets & Ukraine & $4900 \mathrm{~N}$ & $2428 \mathrm{E}$ & Rare Earth Elements, Zirconium & Igneous & Kogarko and others, 1995. \\
\hline Zaval'e (Zavaljevskoje) & Ukraine & $4812 \mathrm{~N}$ & $3002 \mathrm{E}$ & Graphite & Metamorphic & McFaul and others, 2000. \\
\hline Zheltiye Vody & Ukraine & $4825 \mathrm{~N}$ & $3420 \mathrm{E}$ & Scandium, Uranium & Hydrothermal & Kirkham and Rafer, 2003. \\
\hline Frodingham & $\begin{array}{l}\text { United } \\
\text { Kingdom }\end{array}$ & $5335 \mathrm{~N}$ & $0037 \mathrm{~W}$ & Iron & Sedimentary & Kirkham and Rafer, 2003. \\
\hline Geevor & $\begin{array}{l}\text { United } \\
\text { Kingdom }\end{array}$ & $5009 \mathrm{~N}$ & $0541 \mathrm{~W}$ & Tin & Hydrothermal & Sutphin and others, 1990. \\
\hline Hemerdon & $\begin{array}{l}\text { United } \\
\text { Kingdom }\end{array}$ & $5035 \mathrm{~N}$ & $0400 \mathrm{~W}$ & Tungsten, Tin & Hydrothermal & Antony and others, 1988. \\
\hline Northhampton & $\begin{array}{l}\text { United } \\
\text { Kingdom }\end{array}$ & $5208 \mathrm{~N}$ & $0100 \mathrm{~W}$ & Iron & Sedimentary & Kirkham and Rafer, 2003. \\
\hline
\end{tabular}


Table 2A. Mineral deposit name, location, principal commodities, type, and reference for the major metallic mineral deposits in Greenland, Europe, Russia, and Northern Central Asia. Table includes some duplications because of variable transliteration methods. Transliterations of names according to source reference.

\begin{tabular}{|c|c|c|c|c|c|c|}
\hline Deposit Name & Country & Latitude & Longitude & Commodities & Deposit Type & Reference \\
\hline South Crofty & $\begin{array}{l}\text { United } \\
\text { Kingdom }\end{array}$ & $5014 \mathrm{~N}$ & $0507 \mathrm{~W}$ & Tin, Copper, Zinc, Silver & Hydrothermal & Sutphin and others, 1990. \\
\hline Wheal Jane & $\begin{array}{l}\text { United } \\
\text { Kingdom }\end{array}$ & $5014 \mathrm{~N}$ & $0512 \mathrm{~W}$ & Tin & Hydrothermal & Sutphin and others, 1990. \\
\hline Amantaytav & Uzbekistan & $4120 \mathrm{~N}$ & $6419 \mathrm{E}$ & Gold, Silver & Hydrothermal & Seltmann and others, 2003. \\
\hline Aq-Tash & Uzbekistan & $4139 \mathrm{~N}$ & $6946 \mathrm{E}$ & Alunite, Copper, Lead, Molybdenum & Igneous & Seltmann and others, 2003. \\
\hline Ayakkuduk & Uzbekistan & $4112 \mathrm{~N}$ & $6518 \mathrm{E}$ & Iron, Copper & Igneous & Seltmann and others, 2003. \\
\hline Daugyztau & Uzbekistan & $411057 \mathrm{~N}$ & $635852 \mathrm{E}$ & Gold, Silver & Hydrothermal & Seltmann and others, 2003. \\
\hline Ingichke & Uzbekistan & $394416 \mathrm{~N}$ & $65590 \mathrm{E}$ & Tungsten, Tin & Hydrothermal & Natapov and others, 2000. \\
\hline Kalmakyr & Uzbekistan & $4048 \mathrm{~N}$ & $6940 \mathrm{E}$ & Copper, Gold, Molybdenum & Igneous & Seltmann and others, 2003. \\
\hline Khandiza & Uzbekistan & $383305 \mathrm{~N}$ & $673604 \mathrm{E}$ & Lead, Zinc & Hydrothermal & Natapov and others, 2000. \\
\hline Kojtash & Uzbekistan & $401411 \mathrm{~N}$ & $672053 \mathrm{E}$ & Tungsten & Hydrothermal & Natapov and others, 2000. \\
\hline Kokpatas & Uzbekistan & $421424 \mathrm{~N}$ & $634825 \mathrm{E}$ & Gold, Silver, Platinum, Palladium & Igneous & Natapov and others, 2000. \\
\hline Kurganshinan & Uzbekistan & $405253 \mathrm{~N}$ & $694341 \mathrm{E}$ & Silver, Lead, Zinc & Hydrothermal & Natapov and others, 2000. \\
\hline Lashkerek & Uzbekistan & $405343 \mathrm{~N}$ & $701216 \mathrm{E}$ & Lead, Silver & Igneous & Seltmann and others, 2003. \\
\hline Muruntau & Uzbekistan & $4131 \mathrm{~N}$ & $6435 \mathrm{E}$ & Gold & Igneous & Seltmann and others, 2003. \\
\hline Sherabad & Uzbekistan & $375313 \mathrm{~N}$ & $671715 \mathrm{E}$ & Strontium & Sedimentary & Natapov and others, 2000. \\
\hline Uchkulach, Ehksimazar & Uzbekistan & $403610 \mathrm{~N}$ & $671914 \mathrm{E}$ & Lead, Zinc & Hydrothermal & Natapov and others, 2000. \\
\hline Zarmitan & Uzbekistan & $4020 \mathrm{~N}$ & $6644 \mathrm{E}$ & Gold & Igneous & Seltmann and others, 2003. \\
\hline
\end{tabular}


Table 2B. Mineral deposit name, location, principal commodities, type, and reference for the major non-metallic mineral deposits in Greenland, Europe, Russia, and Northern Central Asia. Table includes some duplications because of variable transliteration methods. Transliterations of names according to source reference.

\begin{tabular}{|c|c|c|c|c|c|c|}
\hline Deposit Name & Country & Latitude & Longitude & Commodities & Deposit Type & Reference \\
\hline Breitenau & Austria & $4723 \mathrm{~N}$ & $1529 \mathrm{E}$ & Magnesium & Hydrothermal & Dickson, 1981. \\
\hline Hochfilzen & Austria & $4728 \mathrm{~N}$ & $12037 \mathrm{E}$ & Magnesium & Hydrothermal & Dickson, 1981. \\
\hline Rabenwald-Krughof & Austria & $4717 \mathrm{~N}$ & $15047 \mathrm{E}$ & Talc & Hydrothermal & Dickson, 1981. \\
\hline Radenthein & Austria & $4650 \mathrm{~N}$ & $13039 \mathrm{E}$ & Magnesium & Hydrothermal & Dickson, 1981. \\
\hline Davydovskoe & Belarus & $523351 \mathrm{~N}$ & $29172 \mathrm{E}$ & Halite & Sedimentary & Natapov and others, 2000. \\
\hline Krichev & Belarus & $5342 \mathrm{~N}$ & $3143 \mathrm{E}$ & Phosphate & Sedimentary & Harben and Kuzvart, 1996. \\
\hline Mozyrskoe & Belarus & $515926 \mathrm{~N}$ & $291129 \mathrm{E}$ & Halite & Sedimentary & Natapov and others, 2000. \\
\hline Petrikovskoe & Belarus & $5207 \mathrm{~N}$ & $2830 \mathrm{E}$ & Sylvite, Halite, Bromine & Sedimentary & Troitsky and others, 1998. \\
\hline Starobinsk & Belarus & $525829 \mathrm{~N}$ & $272728 \mathrm{E}$ & Halite, Potash & Sedimentary & Natapov and others, 2000. \\
\hline Ljubija & $\begin{array}{l}\text { Bosnia-Herzeg } \\
\text { ovina }\end{array}$ & $4433 \mathrm{~N}$ & $16018 \mathrm{E}$ & Barite & Sedimentary & Lode, 2003. \\
\hline Tuzla & $\begin{array}{l}\text { Bosnia-Herzeg } \\
\text { ovina }\end{array}$ & $4430 \mathrm{~N}$ & $18045 \mathrm{E}$ & Halite & Sedimentary & Kirkham and Rafer, 2003. \\
\hline Troodos Massif & Cyprus & $3455 \mathrm{~N}$ & $3250 \mathrm{E}$ & Amber & Metamorphic & Harben and Kuzvart, 1996 \\
\hline Borovany & Czech Republic & $4921 \mathrm{~N}$ & $14024 \mathrm{E}$ & Diatomite & Sedimentary & Kuzvart, 1981. \\
\hline Dolni Bory & Czech Republic & $4926 \mathrm{~N}$ & $1601 \mathrm{E}$ & Feldspar & Igneous & $\begin{array}{l}\text { Czech Republic Factbook, } \\
2004 .\end{array}$ \\
\hline Horní Bríza & Czech Republic & $4950 \mathrm{~N}$ & $13022 \mathrm{E}$ & Kaolin & Surficial & Hruska, 1991. \\
\hline Karlovy Vary & Czech Republic & $5013 \mathrm{~N}$ & $12054 \mathrm{E}$ & Kaolin & Surficial & Bolger, 1998. \\
\hline Kaznejov & Czech Republic & $4953 \mathrm{~N}$ & $13022 \mathrm{E}$ & Kaolin & Surficial & Hruska, 1991. \\
\hline Koberice & Czech Republic & $4922 \mathrm{~N}$ & $17007 \mathrm{E}$ & Gypsum & Sedimentary & Hruska, 1991. \\
\hline Podborany & Czech Republic & $5014 \mathrm{~N}$ & $13025 \mathrm{E}$ & Kaolin & Surficial & Bolger, 1996. \\
\hline Siilinjrvi & Finland & $635 \mathrm{~N}$ & $2740 \mathrm{E}$ & Phosphate, Calcium & Sedimentary & Krauss and others, 1984. \\
\hline Albigeois District & France & $4356 \mathrm{~N}$ & $0209 \mathrm{E}$ & Fluorine & Hydrothermal & McFaul and others, 2000. \\
\hline Etang-sur-Arroux & France & $4652 \mathrm{~N}$ & $0411 \mathrm{E}$ & Feldspar & Igneous & $\begin{array}{l}\text { European Association of } \\
\text { Feldspar Producers, } 2004 .\end{array}$ \\
\hline Font Sante & France & $4325 \mathrm{~N}$ & $0646 \mathrm{E}$ & Fluorine & Hydrothermal & McFaul and others, 2000. \\
\hline Glomel & France & $4813 \mathrm{~N}$ & $0324 \mathrm{~W}$ & Andalusite & & $\begin{array}{l}\text { European Association of } \\
\text { Feldspar Producers, } 2004 .\end{array}$ \\
\hline
\end{tabular}


Table 2B. Mineral deposit name, location, principal commodities, type, and reference for the major non-metallic mineral deposits in Greenland, Europe, Russia, and Northern Central Asia. Table includes some duplications because of variable transliteration methods. Transliterations of names according to source reference.

\begin{tabular}{|c|c|c|c|c|c|c|}
\hline Deposit Name & Country & Latitude & Longitude & Commodities & Deposit Type & Reference \\
\hline Morvan District & France & $4957 \mathrm{~N}$ & $0418 \mathrm{E}$ & Fluorine & Hydrothermal & Chermette, 1969 \\
\hline Mulhouse Basin & France & $4646 \mathrm{~N}$ & $0715 \mathrm{E}$ & Potash & Sedimentary & Bouladon, 1989 \\
\hline Pouillon & France & $4336 \mathrm{~N}$ & $0100 \mathrm{E}$ & Gypsum & Sedimentary & Clarke, 1980. \\
\hline $\begin{array}{l}\text { Riom-es-Montagnes } \\
\text { (Bade) }\end{array}$ & France & $4517 \mathrm{~N}$ & $0240 \mathrm{E}$ & Diatomite & Sedimentary & Harben and Kuzvart, 1996. \\
\hline Saline de Hauterives & France & $4516 \mathrm{~N}$ & $0502 \mathrm{E}$ & Halite & Sedimentary & $\begin{array}{l}\text { Roskill Information } \\
\text { Services, } 1983 .\end{array}$ \\
\hline Santa Augusta & France & $4348 \mathrm{~N}$ & $0722 \mathrm{E}$ & Limestone & Sedimentary & Skanska, 2004. \\
\hline Taverny & France & $4902 \mathrm{~N}$ & $0212 \mathrm{E}$ & Gypsum & Sedimentary & Clarke, 1980. \\
\hline Trimouns & France & $4248 \mathrm{~N}$ & $0149 \mathrm{E}$ & Talc & Hydrothermal & Kirkham and Rafer, 2003. \\
\hline Gumbri & Georgia & $4218 \mathrm{~N}$ & $4239 \mathrm{E}$ & Barium & Sedimentary & Troitsky and others, 1988. \\
\hline Kisatibskoe & Georgia & $4133 \mathrm{~N}$ & $4302 \mathrm{E}$ & Diatomite & Sedimentary & Trotskiy and others, 1998. \\
\hline $\begin{array}{l}\text { Bad } \\
\text { Friedrichshall-Kochendorf }\end{array}$ & Germany & $4015 \mathrm{~N}$ & $0911 \mathrm{E}$ & Halite & Surficial & Robbins, 1985 \\
\hline Borth & Germany & $5136 \mathrm{~N}$ & $0633 \mathrm{E}$ & Halite & Sedimentary & Luttig, 1990. \\
\hline Braunschweig-Luneburg & Germany & $521 \mathrm{~N}$ & $10025 \mathrm{E}$ & Halite & Surficial & Roskill, 1983. \\
\hline Clara & Germany & $4823 \mathrm{~N}$ & $0814 \mathrm{E}$ & Barite & Hydrothermal & Harben and Kuzvart, 1996 \\
\hline Epe/Westphalia & Germany & $5111 \mathrm{~N}$ & $0702 \mathrm{E}$ & Halite & Surficial & Roskill, 1983. \\
\hline Frechen & Germany & 5055 & $0649 \mathrm{E}$ & Silica Sand & Surficial & Luttig, 1990. \\
\hline Friedland & Germany & $5125 \mathrm{~N}$ & $9056 \mathrm{E}$ & Kaolin & Sedimentary & Faulk and Hauber, 1990. \\
\hline Haltern & Germany & $5154 \mathrm{~N}$ & $0711 \mathrm{E}$ & Silica Sand & Surficial & Industrial Minerals, 1997. \\
\hline $\begin{array}{l}\text { Heilbronn (Heibronn, } \\
\text { Hielbronn) }\end{array}$ & Germany & $498 \mathrm{~N}$ & $0919 \mathrm{E}$ & Halite & Surficial & Robbins, 1985. \\
\hline Hirschau-Schnaittenbach & Germany & $4932 \mathrm{~N}$ & $11056 \mathrm{E}$ & Kaolin, Feldspar & Sedimentary & Harben and Kuzvart, 1996. \\
\hline Moosburg & Germany & $4828 \mathrm{~N}$ & $11056 \mathrm{E}$ & Bentonite & Hydrothermal & Harben and Kuzvart, 1996 \\
\hline $\begin{array}{l}\text { Muschelkalk } \\
\text { (Sachen-Anhalt) }\end{array}$ & Germany & $5155 \mathrm{~N}$ & $11030 \mathrm{E}$ & Limestone & Sedimentary & Faulk and Hauber, 1990 \\
\hline Niedersachsen-Riedal & Germany & $5235 \mathrm{~N}$ & $10010 \mathrm{E}$ & Potash, Halite & Sedimentary & Garrett, 1996 \\
\hline Niedersachswerfen & Germany & $5134 \mathrm{~N}$ & $10046 \mathrm{E}$ & Gypsum & Sedimentary & Faulk and Hauber, 1990 \\
\hline Rottleberode & Germany & $5131 \mathrm{~N}$ & $10057 \mathrm{E}$ & Fluorine & Hydrothermal & McFaul and others, 2000. \\
\hline
\end{tabular}


Table 2B. Mineral deposit name, location, principal commodities, type, and reference for the major non-metallic mineral deposits in Greenland, Europe, Russia, and Northern Central Asia. Table includes some duplications because of variable transliteration methods. Transliterations of names according to source reference.

\begin{tabular}{|c|c|c|c|c|c|c|}
\hline Deposit Name & Country & Latitude & Longitude & Commodities & Deposit Type & Reference \\
\hline Salzdetfurth & Germany & $523 \mathrm{~N}$ & $1000 \mathrm{E}$ & Potash, Halite, Bromine & Sedimentary & Garrett, 1996. \\
\hline Weferlingen & Germany & $5219 \mathrm{~N}$ & $1102 \mathrm{E}$ & Silica Sand & Surficial & Industrial Minerals, 1997. \\
\hline Milos & Greece & $3640 \mathrm{~N}$ & $2429 \mathrm{E}$ & Bentonite & Hydrothermal & $\begin{array}{l}\text { Hatjilazaridou and others, } \\
1998\end{array}$ \\
\hline Yali & Greece & $3641 \mathrm{~N}$ & $2707 \mathrm{E}$ & Pumice & Igneous & $\begin{array}{l}\text { Hatjilazaridou and others, } \\
1998\end{array}$ \\
\hline Zidani & Greece & $4003 \mathrm{~N}$ & $2154 \mathrm{E}$ & Asbestos & Hydrothermal & Karkanas, 1995 \\
\hline Eger & Hungary & $4754 \mathrm{~N}$ & $2023 \mathrm{E}$ & Limestone & Sedimentary & Kendall, 1994. \\
\hline Egyházaskeszo & Hungary & $4725 \mathrm{~N}$ & $17020 \mathrm{E}$ & Bentonite & Sedimentary & Industrial Minerals, 2002. \\
\hline Palhaza (Mt. Gyongyko) & Hungary & $4111 \mathrm{~N}$ & $19045 \mathrm{E}$ & Perlite & Igneous & Molnar, 1989. \\
\hline Lake Myvatn & Iceland & $6534 \mathrm{~N}$ & $17002 \mathrm{~W}$ & Diatomite & Sedimentary & Seacology, 2004. \\
\hline Acquacalda & Italy & $3815 \mathrm{~N}$ & $14057 \mathrm{E}$ & Pumice & Igneous & Italpumice, S.p.A., 2004. \\
\hline Belangero & Italy & $4500 \mathrm{~N}$ & $0725 \mathrm{E}$ & Asbestos & Hydrothermal & McFaul and others, 2000. \\
\hline Brusnengo & Italy & $4500 \mathrm{~N}$ & $0815 \mathrm{E}$ & Feldspar & Igneous & Loughbrough, 1992. \\
\hline Campiglia Marittima & Italy & $433 \mathrm{~N}$ & $10037 \mathrm{E}$ & Feldspar & Igneous & Loughbrough, 1992. \\
\hline Mont 'Ega (Montega) & Italy & $3911 \mathrm{~N}$ & $0840 \mathrm{E}$ & Barium, Fluorine, Lead & Hydrothermal & Harben and Kuzvart, 1996. \\
\hline Morgongiori & Italy & $3945 \mathrm{~N}$ & $0846 \mathrm{E}$ & Perlite & Igneous & Harben and Kuzvart, 1996 \\
\hline Porticello & Italy & $3806 \mathrm{~N}$ & $13031 \mathrm{E}$ & Pumice & Igneous & Italpumice, S.p.A., 2004 \\
\hline Volterra & Italy & $4323 \mathrm{~N}$ & $10045 \mathrm{E}$ & Halite & Sedimentary & $\begin{array}{l}\text { Roskill Information } \\
\text { Services, } 1983 .\end{array}$ \\
\hline Ivittuut, Ivigtut & $\begin{array}{l}\text { Kalaallit } \\
\text { Nunaat }\end{array}$ & $6112 \mathrm{~N}$ & $4811 \mathrm{~W}$ & Cryolite & Igneous & Wooley, 1987. \\
\hline Aksaj, Chulaktau & Kazakhstan & $43840 \mathrm{~N}$ & $702717 \mathrm{E}$ & Phosphate & Sedimentary & Natapov and others, 2000. \\
\hline Aktyubinsk & Kazakhstan & $5016 \mathrm{~N}$ & $5720 \mathrm{E}$ & Phosphate & Sedimentary & Kirkham and Rafer, 2003. \\
\hline Boldulakskoe & Kazakhstan & $444112 \mathrm{~N}$ & $532850 \mathrm{E}$ & Halite & Sedimentary & Natapov and others, 2000. \\
\hline Bugetysajskoe, Ijul'skoe & Kazakhstan & $491140 \mathrm{~N}$ & $591017 \mathrm{E}$ & Asbestos & Metamorphic & Natapov and others, 2000. \\
\hline Chiganak & Kazakhstan & $45224 \mathrm{~N}$ & $734234 \mathrm{E}$ & Barium & Sedimentary & Natapov and others, 2000. \\
\hline Chilisai & Kazakhstan & $4925 \mathrm{~N}$ & $5720 \mathrm{E}$ & Phosphate & Sedimentary & Seltmann and others, 2003. \\
\hline Chulaktau-I & Kazakhstan & $439 \mathrm{~N}$ & $7029 \mathrm{E}$ & Phosphate & Sedimentary & Seltmann and others, 2003. \\
\hline
\end{tabular}


Table 2B. Mineral deposit name, location, principal commodities, type, and reference for the major non-metallic mineral deposits in Greenland, Europe, Russia, and Northern Central Asia. Table includes some duplications because of variable transliteration methods. Transliterations of names according to source reference.

\begin{tabular}{|c|c|c|c|c|c|c|}
\hline Deposit Name & Country & Latitude & Longitude & Commodities & Deposit Type & Reference \\
\hline Druzhba A & Kazakhstan & $513224 \mathrm{~N}$ & $76408 \mathrm{E}$ & Titanium, Zirconium, Diamond & Surficial & Natapov and others, 2000. \\
\hline Dzhetygarinskoe 1 & Kazakhstan & $5289 \mathrm{~N}$ & $61848 \mathrm{E}$ & Asbestos & Metamorphic & Natapov and others, 2000. \\
\hline Dzhetygarinskoe 2 & Kazakhstan & $521341 \mathrm{~N}$ & $611436 \mathrm{E}$ & Talc & Igneous & Natapov and others, 2000. \\
\hline Eshkeul'messkoe & Kazakhstan & $485046 \mathrm{~N}$ & $67513 \mathrm{E}$ & Asbestos & Metamorphic & Natapov and others, 2000. \\
\hline Inderskaja & Kazakhstan & $484015 \mathrm{~N}$ & $515659 \mathrm{E}$ & Halite & Sedimentary & Natapov and others, 2000. \\
\hline Inderskoe & Kazakhstan & $484423 \mathrm{~N}$ & $521126 \mathrm{E}$ & Boron & Sedimentary & Natapov and others, 2000. \\
\hline Janytas & Kazakhstan & $4333 \mathrm{~N}$ & $6936 \mathrm{E}$ & Phosphate & Sedimentary & Seltmann and others, 2003. \\
\hline Kajdakskoe & Kazakhstan & $442552 \mathrm{~N}$ & $53239 \mathrm{E}$ & Halite & Sedimentary & Natapov and others, 2000. \\
\hline Kajraktinskoe, Altyntas & Kazakhstan & $493311 \mathrm{~N}$ & $59395 \mathrm{E}$ & Vermiculite & Surficial & Natapov and others, 2000. \\
\hline Kaldygajtinskoe & Kazakhstan & $494823 \mathrm{~N}$ & $533621 \mathrm{E}$ & Halite & Sedimentary & Natapov and others, 2000. \\
\hline $\begin{array}{l}\text { Kamyskol'skoe, } \\
\text { Karakamysskoe }\end{array}$ & Kazakhstan & $491858 \mathrm{~N}$ & $53403 \mathrm{E}$ & Halite & Sedimentary & Natapov and others, 2000. \\
\hline Karakudukskoe & Kazakhstan & $502810 \mathrm{~N}$ & $594451 \mathrm{E}$ & Talc & Igneous & Natapov and others, 2000. \\
\hline Karanynsaj-Temborgen & Kazakhstan & $473328 \mathrm{~N}$ & $582232 \mathrm{E}$ & Phosphate & Sedimentary & Natapov and others, 2000. \\
\hline Karatau Basin & Kazakhstan & $4430 \mathrm{~N}$ & $7000 \mathrm{E}$ & Phosphate & Sedimentary & Kirkham and Rafer, 2003. \\
\hline Kenterlauskoe & Kazakhstan & $465710 \mathrm{~N}$ & $755653 \mathrm{E}$ & Talc & Igneous & Natapov and others, 2000. \\
\hline Koksu & Kazakhstan & $43359 \mathrm{~N}$ & $693449 \mathrm{E}$ & Phosphate & Sedimentary & Seltmann and others, 2003. \\
\hline Krasnomajskoe & Kazakhstan & $531323 \mathrm{~N}$ & $684920 \mathrm{E}$ & Vermiculite & Surficial & Natapov and others, 2000. \\
\hline Kudajberginskoe & Kazakhstan & $473836 \mathrm{~N}$ & $483058 \mathrm{E}$ & Halite & Sedimentary & Natapov and others, 2000. \\
\hline Kulet & Kazakhstan & $53051 \mathrm{~N}$ & $69375 \mathrm{E}$ & Muscovite & Metamorphic & Natapov and others, 2000. \\
\hline Melovoe & Kazakhstan & $43418 \mathrm{~N}$ & $512918 \mathrm{E}$ & Phosphate & Sedimentary & Natapov and others, 2000. \\
\hline Nenazvannoe & Kazakhstan & $484054 \mathrm{~N}$ & $511328 \mathrm{E}$ & Halite & Sedimentary & Natapov and others, 2000. \\
\hline Novoaleksandrovskoe & Kazakhstan & $445922 \mathrm{~N}$ & $534830 \mathrm{E}$ & Halite & Sedimentary & Natapov and others, 2000. \\
\hline Pokrovskoe & Kazakhstan & $49178 \mathrm{~N}$ & $564543 \mathrm{E}$ & Phosphate & Sedimentary & Natapov and others, 2000. \\
\hline Shalkarskoe & Kazakhstan & $502940 \mathrm{~N}$ & $514531 \mathrm{E}$ & Boron & Sedimentary & Natapov and others, 2000. \\
\hline Shalkarskoe & Kazakhstan & $502323 \mathrm{~N}$ & $515533 \mathrm{E}$ & Sylvite, Halite & Sedimentary & Natapov and others, 2000. \\
\hline Taskainar South & Kazakhstan & $438 \mathrm{~N}$ & $755 \mathrm{E}$ & Fluorine & Igneous & Seltmann and others, 2003. \\
\hline Zhalair & Kazakhstan & $493238 \mathrm{~N}$ & $72509 \mathrm{E}$ & Barium & Sedimentary & Natapov and others, 2000. \\
\hline
\end{tabular}


Table 2B. Mineral deposit name, location, principal commodities, type, and reference for the major non-metallic mineral deposits in Greenland, Europe, Russia, and Northern Central Asia. Table includes some duplications because of variable transliteration methods. Transliterations of names according to source reference.

\begin{tabular}{|c|c|c|c|c|c|c|}
\hline Deposit Name & Country & Latitude & Longitude & Commodities & Deposit Type & Reference \\
\hline Zhalauly & Kazakhstan & $525310 \mathrm{~N}$ & $741429 \mathrm{E}$ & Halite & Sedimentary & Natapov and others, 2000. \\
\hline Zhanatas (Dzhanatas) & Kazakhstan & $4333 \mathrm{~N}$ & $6936 \mathrm{E}$ & Phosphate & Sedimentary & Seltmann and others, 2003. \\
\hline Gradesnica & Macedonia & $4105 \mathrm{~N}$ & $2146 \mathrm{E}$ & Perlite & Igneous & Harben and Kuzvart, 1996. \\
\hline Hengelo & Netherlands & $5216 \mathrm{~N}$ & $0648 \mathrm{E}$ & Halite & Sedimentary & $\begin{array}{l}\text { Roskill Information } \\
\text { Services, } 1983 .\end{array}$ \\
\hline Weerselo & Netherlands & $5250 \mathrm{~N}$ & $6030 \mathrm{E}$ & Halite & Sedimentary & Kirkham and Rafer, 2003. \\
\hline Winschoten & Netherlands & $5309 \mathrm{~N}$ & $0702 \mathrm{E}$ & Halite & Surficial & $\begin{array}{l}\text { Roskill Information } \\
\text { Services, } 1983\end{array}$ \\
\hline Aheim & Norway & $622 \mathrm{~N}$ & $0532 \mathrm{E}$ & Olivine & Metamorphic & Olerud, 1993. \\
\hline Granasen & Norway & $6217 \mathrm{~N}$ & $0532 \mathrm{E}$ & Dolomite & Sedimentary & Karlsen, 1998. \\
\hline Stranda & Norway & $6218 \mathrm{~N}$ & $0654 \mathrm{E}$ & Olivine & Metamorphic & Olerud, 1993. \\
\hline Jeziorko & Poland & $5034 \mathrm{~N}$ & $2149 \mathrm{E}$ & Sulfur & Hydrothermal & Notholt, 1991. \\
\hline Kletno III & Poland & $5318 \mathrm{~N}$ & $16053 \mathrm{E}$ & Limestone & Sedimentary & $\begin{array}{l}\text { Jaskinia Niedêwiedzia, } \\
2004 .\end{array}$ \\
\hline Klodawa & Poland & $5215 \mathrm{~N}$ & $18055 \mathrm{E}$ & Halite, Potash & Sedimentary & Harben and Kuzvart, 1996. \\
\hline Salamonde & Portugal & $4138 \mathrm{~N}$ & $0809 \mathrm{~W}$ & Feldspar & Igneous & Mindat, 2004. \\
\hline $\begin{array}{l}\text { Ajkhal pipe, Alakitskoe } \\
\text { field }\end{array}$ & Russia & $66026 \mathrm{~N}$ & $1113653 \mathrm{E}$ & Diamond & Igneous & Ariunbileg and others, 2003. \\
\hline Bazhenovo & Russia & $5720 \mathrm{~N}$ & $61300 \mathrm{E}$ & Asbestos & Metamorphic & Kirkham and Rafer, 2003. \\
\hline Dalnegorsk & Russia & $442841 \mathrm{~N}$ & $1353454 \mathrm{E}$ & Boron & Hydrothermal & Ariunbileg and others, 2003. \\
\hline Elton (Lake) & Russia & $4916 \mathrm{~N}$ & $4635 \mathrm{E}$ & Halite, Bromine & Sedimentary & Troitsky and others, 1998. \\
\hline Gremyakha-Vyrmes & Russia & $6838 \mathrm{~N}$ & $3228 \mathrm{E}$ & Titanium, Iron, Phosphate & Igneous & Kogarko and others, 1995. \\
\hline Internacional'naja pipe & Russia & $654911 \mathrm{~N}$ & $1113431 \mathrm{E}$ & Diamond & Igneous & Natapov and others, 2000. \\
\hline Kuchuk, Lake & Russia & $5242 \mathrm{~N}$ & $7946 \mathrm{E}$ & Sodium Sulfate, Bromine & Sedimentary & Troitsky and others, 1998. \\
\hline Lazinskoe & Russia & $5352 \mathrm{~N}$ & $3924 \mathrm{E}$ & Gypsum & Sedimentary & Troitsky and others, 1998 \\
\hline Lupikko & Russia & $6133 \mathrm{~N}$ & $3133 \mathrm{E}$ & Feldspar & Igneous & Troitsky and others, 1998. \\
\hline Mir-Sputnik & Russia & $681217 \mathrm{~N}$ & $1405331 \mathrm{E}$ & Diamond & Igneous & Ariunbileg and others, 2003. \\
\hline $\begin{array}{l}\text { Nepskaja Group } \\
\text { (Gazhenka, Datkon) }\end{array}$ & Russia & $591240 \mathrm{~N}$ & $1075452 \mathrm{E}$ & Sylvite & Sedimentary & Natapov and others, 2000. \\
\hline Novomoskovskoe & Russia & $5405 \mathrm{~N}$ & $3813 \mathrm{E}$ & Gypsum & Sedimentary & Troitsky and others, 1998. \\
\hline
\end{tabular}


Table 2B. Mineral deposit name, location, principal commodities, type, and reference for the major non-metallic mineral deposits in Greenland, Europe, Russia, and Northern Central Asia. Table includes some duplications because of variable transliteration methods. Transliterations of names according to source reference.

\begin{tabular}{|c|c|c|c|c|c|c|}
\hline Deposit Name & Country & Latitude & Longitude & Commodities & Deposit Type & Reference \\
\hline $\begin{array}{l}\text { Ozjornaja, Jubilejnaja } \\
\text { pipes }\end{array}$ & Russia & $655558 \mathrm{~N}$ & $1105116 \mathrm{E}$ & Diamond & Igneous & Natapov and others, 2000. \\
\hline Savinskoe & Russia & $5235 \mathrm{~N}$ & $10208 \mathrm{E}$ & Magnesium & Hydrothermal & Ariunbileg and others, 2003. \\
\hline Seligdarskoe & Russia & $5824 \mathrm{~N}$ & $12518 \mathrm{E}$ & Phosphate, Rare Earth Elements & Igneous & Kogarko and others, 1995. \\
\hline Seregovskoe & Russia & $622030 \mathrm{~N}$ & $503625 \mathrm{E}$ & Halite & Sedimentary & Natapov and others, 2000. \\
\hline Shabrovskoe & Russia & $563034 \mathrm{~N}$ & $604638 \mathrm{E}$ & Talc & Igneous & Natapov and others, 2000. \\
\hline Shedokskoe & Russia & $4413 \mathrm{~N}$ & $4051 \mathrm{E}$ & Halite & Sedimentary & Troitsky and others, 1998 \\
\hline $\begin{array}{l}\text { Sytykanskaja, Snezhinka } \\
\text { pipes }\end{array}$ & Russia & $662134 \mathrm{~N}$ & $111260 \mathrm{E}$ & Diamond & Igneous & Natapov and others, 2000. \\
\hline $\begin{array}{l}\text { Telek (Telekskoye, } \\
\text { Bol'Shoy Telek) }\end{array}$ & Russia & $54170 \mathrm{~N}$ & $9230 \mathrm{E}$ & Phosphate & Sedimentary & McFaul and others, 2000. \\
\hline $\begin{array}{l}\text { Tyretskoe } \\
\text { (Usol'sko-Bulajskoe) }\end{array}$ & Russia & $533813 \mathrm{~N}$ & $1022247 \mathrm{E}$ & Halite & Sedimentary & Natapov and others, 2000. \\
\hline Udachnaya & Russia & $6626 \mathrm{E}$ & $11213 \mathrm{E}$ & Diamond & Igneous & Ariunbileg and others, 2003. \\
\hline Udarnoe, Popigajskaja & Russia & $714440 \mathrm{~N}$ & $111913 \mathrm{E}$ & Diamond & Igneous & Natapov and others, 2000. \\
\hline Verkhnekamsk & Russia & $593644 \mathrm{~N}$ & $564516 \mathrm{E}$ & Halite, Caranallite, Potash & Sedimentary & Kirkham and Rafer, 2003. \\
\hline Verkhotina & Russia & $65400 \mathrm{~N}$ & $40400 \mathrm{E}$ & Diamond & Igneous & Kirkham and Rafer, 2003. \\
\hline Viatka Kama (Rudnichny) & Russia & $5937 \mathrm{~N}$ & $5228 \mathrm{E}$ & Phosphate & Sedimentary & McFaul and others, 2000. \\
\hline Voznesenka-2 & Russia & $441101 \mathrm{~N}$ & $1320805 \mathrm{E}$ & Fluorine & Igneous & Natapov and others, 2000. \\
\hline Yubileinaya & Russia & $6600 \mathrm{~N}$ & $11141 \mathrm{E}$ & Diamond & Igneous & Ariunbileg and others, 2003. \\
\hline Ddbrava-Miková & Slovakia & $4839 \mathrm{~N}$ & $2014 \mathrm{E}$ & Magnesium & Hydrothermal & Grenda and Trading, 1994. \\
\hline Kosice & Slovakia & $4843 \mathrm{~N}$ & $2115 \mathrm{E}$ & Magnesium & Sedimentary & Hruska, 1991. \\
\hline Lehotka pod Brehy & Slovakia & $4833 \mathrm{~N}$ & $18048 \mathrm{E}$ & Perlite & Igneous & Harben and Kuzvart, 1996. \\
\hline Lubenik & Slovakia & $4840 \mathrm{~N}$ & $2012 \mathrm{E}$ & Magnesium & Hydrothermal & Harben and Kuzvart, 1996. \\
\hline Male Krstenany & Slovakia? & $4838 \mathrm{~N}$ & $18026 \mathrm{E}$ & Dolomite & Sedimentary & Hruska, 1991. \\
\hline Mociar & Slovakia & $4821 \mathrm{~N}$ & $19015 \mathrm{E}$ & Diatomite & Sedimentary & Hruska, 1991. \\
\hline Aldea Moret & Spain & $3925 \mathrm{~N}$ & $0625 \mathrm{~W}$ & Phosphate & Igneous & $\begin{array}{l}\text { British Sulphur Corporation, } \\
1987 .\end{array}$ \\
\hline Cerezo de Rio Tiron & Spain & $4229 \mathrm{~N}$ & $0308 \mathrm{~W}$ & Sodium Sulphate & Sedimentary & $\begin{array}{l}\text { Regueiro y Gonzalez-Barros, } \\
1995 .\end{array}$ \\
\hline
\end{tabular}


Table 2B. Mineral deposit name, location, principal commodities, type, and reference for the major non-metallic mineral deposits in Greenland, Europe, Russia, and Northern Central Asia. Table includes some duplications because of variable transliteration methods. Transliterations of names according to source reference.

\begin{tabular}{|c|c|c|c|c|c|c|}
\hline Deposit Name & Country & Latitude & Longitude & Commodities & Deposit Type & Reference \\
\hline El Castellar & Spain & $3952 \mathrm{~N}$ & $0401 \mathrm{~W}$ & Sodium Sulphate & Sedimentary & Vazquez-Guzman, 1989. \\
\hline Huelva & Spain & $3716 \mathrm{~N}$ & $0657 \mathrm{~W}$ & Halite & Sedimentary & $\begin{array}{l}\text { Roskill Information } \\
\text { Services, } 1983 .\end{array}$ \\
\hline Pinoso & Spain & $3824 \mathrm{~N}$ & $0102 \mathrm{~W}$ & Halite & Sedimentary & Vazquez-Guzman, 1989. \\
\hline Suria & Spain & $4150 \mathrm{~N}$ & $0145 \mathrm{E}$ & Potash & Sedimentary & Pearse, 2000. \\
\hline Torrelavega & Spain & $4321 \mathrm{~N}$ & $0403 \mathrm{~W}$ & Halite & Sedimentary & $\begin{array}{l}\text { Roskill Information } \\
\text { Services, } 1983 .\end{array}$ \\
\hline Vicalvaro-Vallecas & Spain & $4024 \mathrm{~N}$ & $0336 \mathrm{~W}$ & Sepiolite & Sedimentary & Harben and Kuzvart, 1996. \\
\hline Backegruvan & Sweden & $5850 \mathrm{~N}$ & $15034 \mathrm{E}$ & Feldspar & Igneous & International Minerals, 1999. \\
\hline Gotland & Sweden & $5750 \mathrm{~N}$ & $18048 \mathrm{E}$ & Limestone & Sedimentary & Wikk, 1996. \\
\hline $\begin{array}{l}\text { Khodzhamunyn, } \\
\text { Khodzhasartys }\end{array}$ & Tajikistan & $374357 \mathrm{~N}$ & $693336 \mathrm{E}$ & Halite & Sedimentary & Natapov and others, 2000. \\
\hline Nurek & Tajikistan & $382325 \mathrm{~N}$ & $691911 \mathrm{E}$ & Halite & Sedimentary & Natapov and others, 2000. \\
\hline Tanapchi & Tajikistan & $375456 \mathrm{~N}$ & $693012 \mathrm{E}$ & Halite & Sedimentary & Natapov and others, 2000. \\
\hline Tutbulak & Tajikistan & $38162 \mathrm{~N}$ & $69359 \mathrm{E}$ & Halite & Sedimentary & Natapov and others, 2000. \\
\hline Chashranta & Turkmenistan & $37358 \mathrm{~N}$ & $661148 \mathrm{E}$ & Sylvite & Sedimentary & Natapov and others, 2000. \\
\hline Divichi-Burunskoe & Turkmenistan & $393214 \mathrm{~N}$ & $53260 \mathrm{E}$ & Halite & Sedimentary & Natapov and others, 2000. \\
\hline Gaurdak & Turkmenistan & $3750 \mathrm{~N}$ & $6610 \mathrm{E}$ & Potash, Sulfur & Sedimentary & McFaul and others, 2002. \\
\hline Karashor & Turkmenistan & $40319 \mathrm{~N}$ & $565239 \mathrm{E}$ & Halite & Sedimentary & Natapov and others, 2000. \\
\hline Sultan-Sandzharskoe & Turkmenistan & $41636 \mathrm{~N}$ & $613355 \mathrm{E}$ & Halite & Sedimentary & Natapov and others, 2000. \\
\hline Zaliv Kara-Bogaz-Gol & Turkmenistan & $42512 \mathrm{~N}$ & $532221 \mathrm{E}$ & Halite & Sedimentary & Natapov and others, 2000. \\
\hline Artemovskoe & Ukraine & $4742 \mathrm{~N}$ & $3838 \mathrm{E}$ & Gypsum, Halite & Sedimentary & Troitsky and others, 1998. \\
\hline $\begin{array}{l}\text { Chernigovskii } \\
\text { (Novopoltavskii) }\end{array}$ & Ukraine & $4714 \mathrm{~N}$ & $3615 \mathrm{E}$ & $\begin{array}{l}\text { Phosphorus, Rare Earth Elements, } \\
\text { Iron, Titanium }\end{array}$ & Igneous & Kogarko, 1996. \\
\hline Komsomolskoe & Ukraine & $4740 \mathrm{~N}$ & $3805 \mathrm{E}$ & Limestone & Sedimentary & O'Driscoll, 1998 \\
\hline Novorayskoe & Ukraine & $4835 \mathrm{~N}$ & $3729 \mathrm{E}$ & Kaolin & Sedimentary & O'Driscoll, 1998. \\
\hline Oktyabrskoye & Ukraine & $4825 \mathrm{~N}$ & $3710 \mathrm{e}$ & Kaolin & Sedimentary & O'Driscoll, 1998. \\
\hline Petrikovskoe & Ukraine & $484755 \mathrm{~N}$ & $342915 \mathrm{E}$ & Potash, Halite, Bromine & Sedimentary & Troitsky and others, 1998. \\
\hline Sivash & Ukraine & $4557 \mathrm{~N}$ & $3350 \mathrm{E}$ & Bromine & Sedimentary & Troitsky and others, 1998. \\
\hline
\end{tabular}


Table 2B. Mineral deposit name, location, principal commodities, type, and reference for the major non-metallic mineral deposits in Greenland, Europe, Russia, and Northern Central Asia. Table includes some duplications because of variable transliteration methods. Transliterations of names according to source reference.

\begin{tabular}{|c|c|c|c|c|c|c|}
\hline Deposit Name & Country & Latitude & Longitude & Commodities & Deposit Type & Reference \\
\hline Slavyanskoe & Ukraine & $4855 \mathrm{~N}$ & $3350 \mathrm{E}$ & Halite & Sedimentary & Troitsky and others, 1998. \\
\hline Stebnikovskoe (Stebnik) & Ukraine & $4915 \mathrm{~N}$ & $2340 \mathrm{E}$ & Potash & Sedimentary & Troitsky and others, 1998. \\
\hline $\begin{array}{l}\text { Vilnohirsk (Mayshev, } \\
\text { Dnieproperovsk) }\end{array}$ & Ukraine & $482900 \mathrm{~N}$ & $340115 \mathrm{E}$ & $\begin{array}{l}\text { Titanium, Zirconium, Kyanite, } \\
\text { Staurolite }\end{array}$ & Surficial & O'Driscoll, 1998 \\
\hline Bodmin Moor & $\begin{array}{l}\text { United } \\
\text { Kingdom }\end{array}$ & $5022 \mathrm{~N}$ & $0436 \mathrm{~W}$ & Kaolin & Hydrothermal & Harben and Kuzvart, 1996. \\
\hline Boulby & $\begin{array}{l}\text { United } \\
\text { Kingdom }\end{array}$ & $5434 \mathrm{~N}$ & $0049 \mathrm{~W}$ & Potash & Sedimentary & Mining Technology, 2004 \\
\hline Bovey Basin & $\begin{array}{l}\text { United } \\
\text { Kingdom }\end{array}$ & $5033 \mathrm{~N}$ & $0336 \mathrm{~W}$ & Kaolin & Sedimentary & Harries-Rees, 1992. \\
\hline Dene Quarry & $\begin{array}{l}\text { United } \\
\text { Kingdom }\end{array}$ & $5306 \mathrm{~N}$ & $0133 \mathrm{~W}$ & Limestone & Sedimentary & $\begin{array}{l}\text { British Geological Survey, } \\
2004\end{array}$ \\
\hline Lee Moor & $\begin{array}{l}\text { United } \\
\text { Kingdom }\end{array}$ & $5026 \mathrm{~N}$ & $0400 \mathrm{~W}$ & Kaolin & Hydrothermal & Bristow and others, 2002. \\
\hline Norwich & $\begin{array}{l}\text { United } \\
\text { Kingdom }\end{array}$ & $5238 \mathrm{~N}$ & $0118 \mathrm{E}$ & Halite & Sedimentary & $\begin{array}{l}\text { Roskill Information } \\
\text { Services, } 1983 .\end{array}$ \\
\hline Peninine & $\begin{array}{l}\text { United } \\
\text { Kingdom }\end{array}$ & $538 \mathrm{~N}$ & $0132 \mathrm{~W}$ & Fluorine & Igneous & McFaul and others, 2000. \\
\hline St. Austell & $\begin{array}{l}\text { United } \\
\text { Kingdom }\end{array}$ & $5022 \mathrm{~N}$ & $0453 \mathrm{~W}$ & Kaolin & Hydrothermal & Harben and Kuzvart, 1996. \\
\hline St. Austell & $\begin{array}{l}\text { United } \\
\text { Kingdom }\end{array}$ & $5022 \mathrm{~N}$ & $0453 \mathrm{~W}$ & Kaolin & Hydrothermal & Harben and Kuzvart, 1996. \\
\hline Akzamar (Azkamar) & Uzbekistan & $3959 \mathrm{~N}$ & $6454 \mathrm{E}$ & Bentonite & Sedimentary & Troitsky and others, 1998. \\
\hline Dzheroj-Syrdara (Sardara) & Uzbekistan & $412141 \mathrm{~N}$ & $643043 \mathrm{E}$ & Phosphate & Sedimentary & Natapov and others, 2000. \\
\hline Dzheroj-Tashkura & Uzbekistan & $41354 \mathrm{~N}$ & $641038 \mathrm{E}$ & Phosphate & Sedimentary & Natapov and others, 2000. \\
\hline
\end{tabular}


Table 3. Mineral deposit types, processes of formations, and examples.

\begin{tabular}{|c|c|c|}
\hline Mineral Deposit Type & Process of Formation & Examples \\
\hline Surficial deposits & $\begin{array}{l}\text { Deposits that form at the Earth's surface } \\
\text { by residual effects of weathering or } \\
\text { by the mechanical concentration of } \\
\text { minerals by flowing water. }\end{array}$ & $\begin{array}{l}\text { Deposits enriched in residual aluminum, } \\
\text { nickel, and clay. Placer deposits of gold, } \\
\text { platinum, and titanium. }\end{array}$ \\
\hline Sedimentary deposits & $\begin{array}{l}\text { Deposits that form from surface waters } \\
\text { that chemically precipitated the } \\
\text { minerals. Includes evaporite deposits. }\end{array}$ & $\begin{array}{l}\text { Sedimentary layers of salts such as halite and } \\
\text { potash, phosphate, most iron deposits, and } \\
\text { limestone. }\end{array}$ \\
\hline Hydrothermal deposits & $\begin{array}{l}\text { Deposits that form mostly from fluids in } \\
\text { veins at moderate temperatures. }\end{array}$ & $\begin{array}{l}\text { Some gold and silver deposits, lead-zinc- } \\
\text { copper polymetallic veins deposits, hot } \\
\text { spring deposits, and porphyry copper } \\
\text { deposits. }\end{array}$ \\
\hline Igneous deposits & $\begin{array}{l}\text { Deposits that form from the } \\
\text { crystallization of molten rock. }\end{array}$ & $\begin{array}{l}\text { Nickel deposits, gemstones in pegmatite } \\
\text { deposits, rare-earth element deposits. }\end{array}$ \\
\hline Metamorphic deposits & $\begin{array}{l}\text { Deposits that form when rocks are } \\
\text { metamorphosed by heat and pressure. }\end{array}$ & $\begin{array}{l}\text { Graphite, magnesite, talc, and wollastonite } \\
\text { deposits. }\end{array}$ \\
\hline
\end{tabular}




\section{Figures}

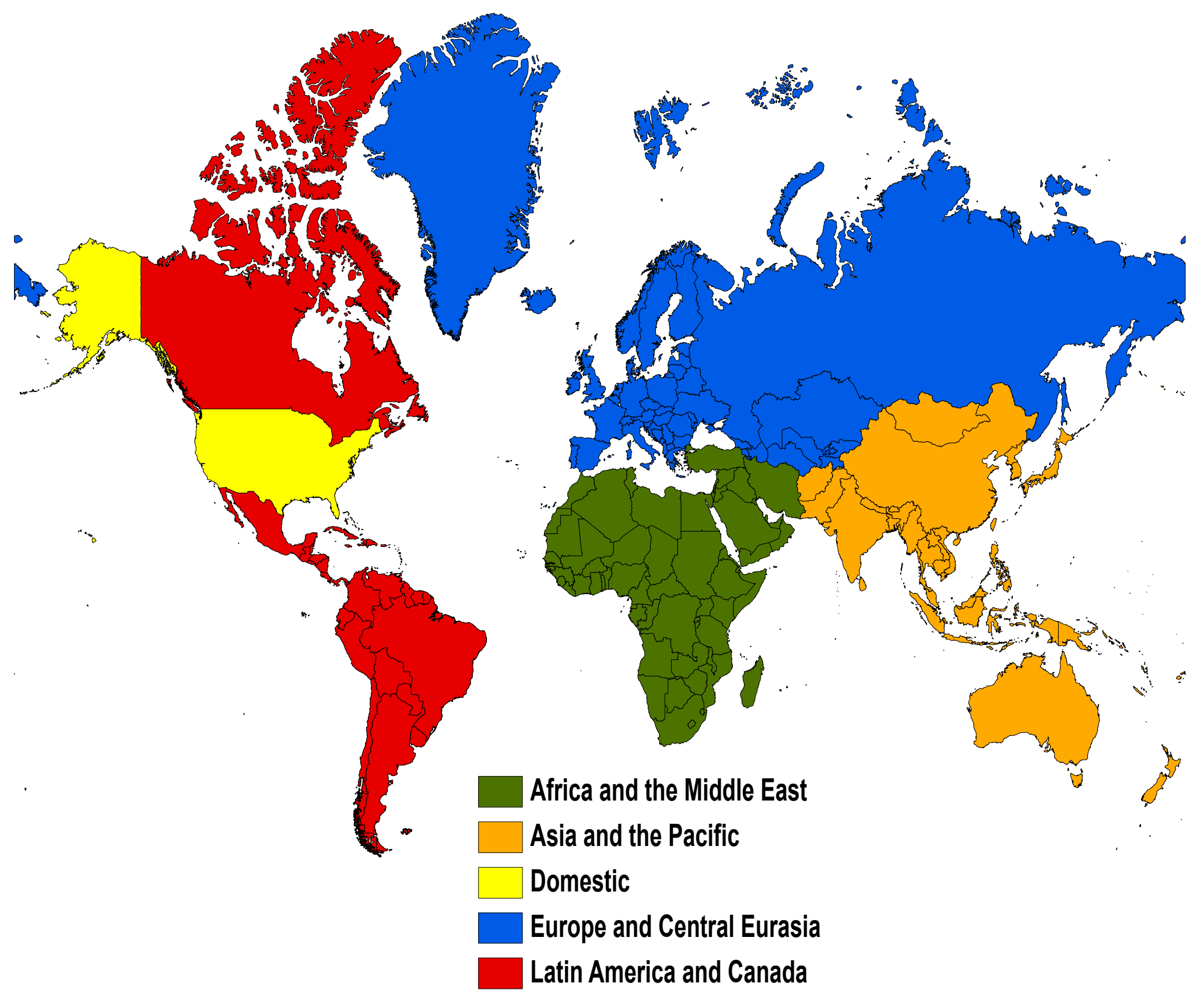

Figure 1. Areas of the regional reports. The area of this report is in blue. 


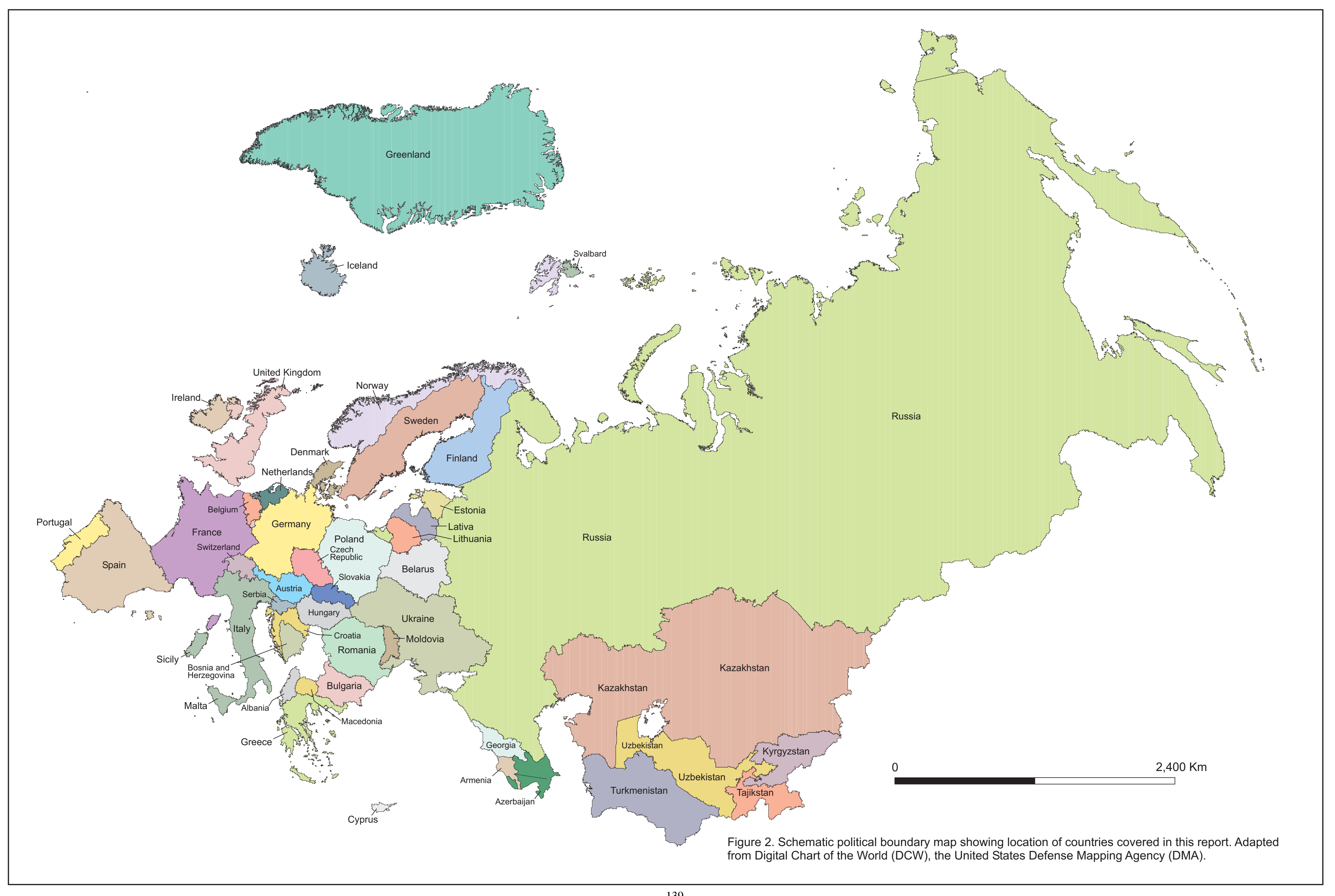




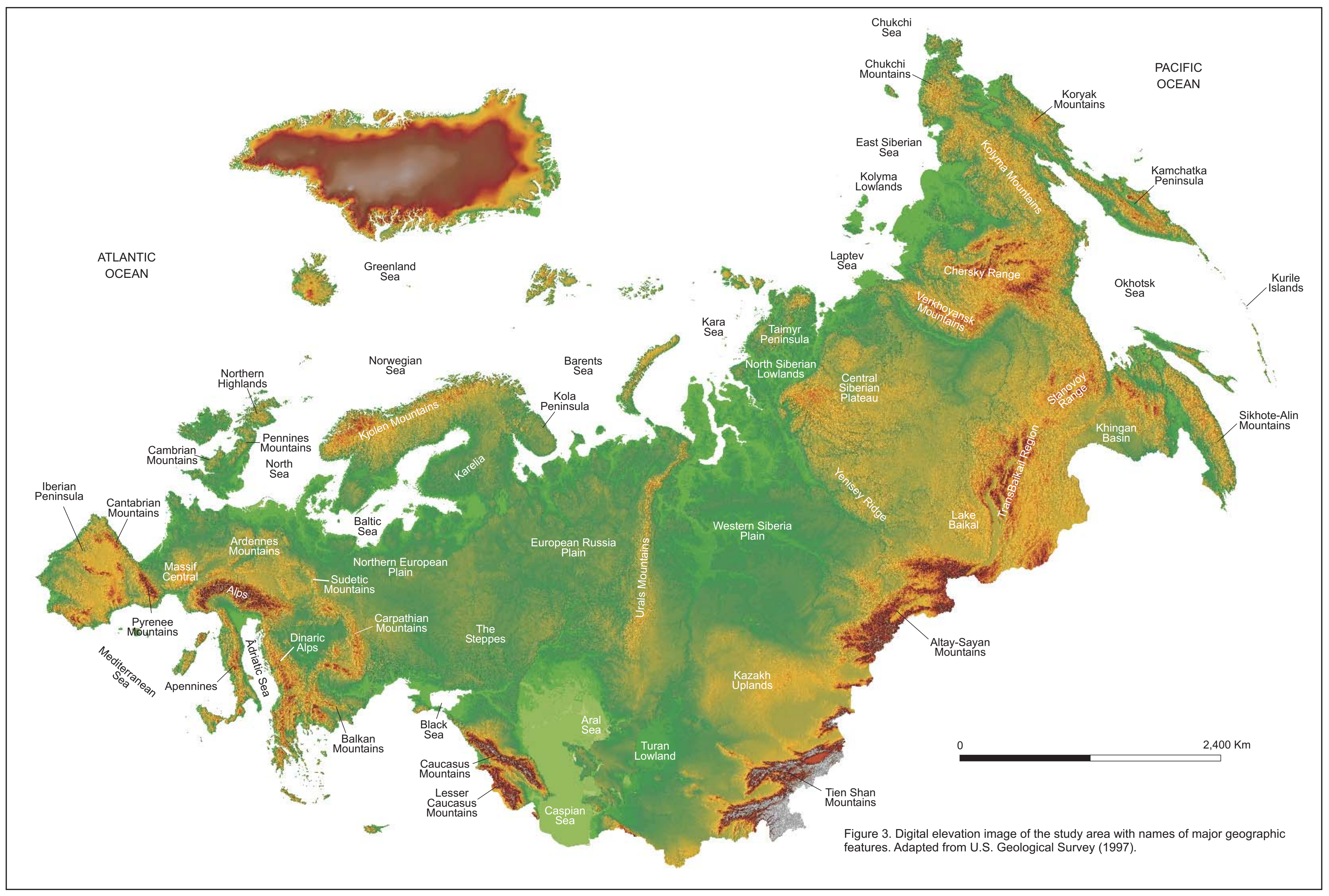




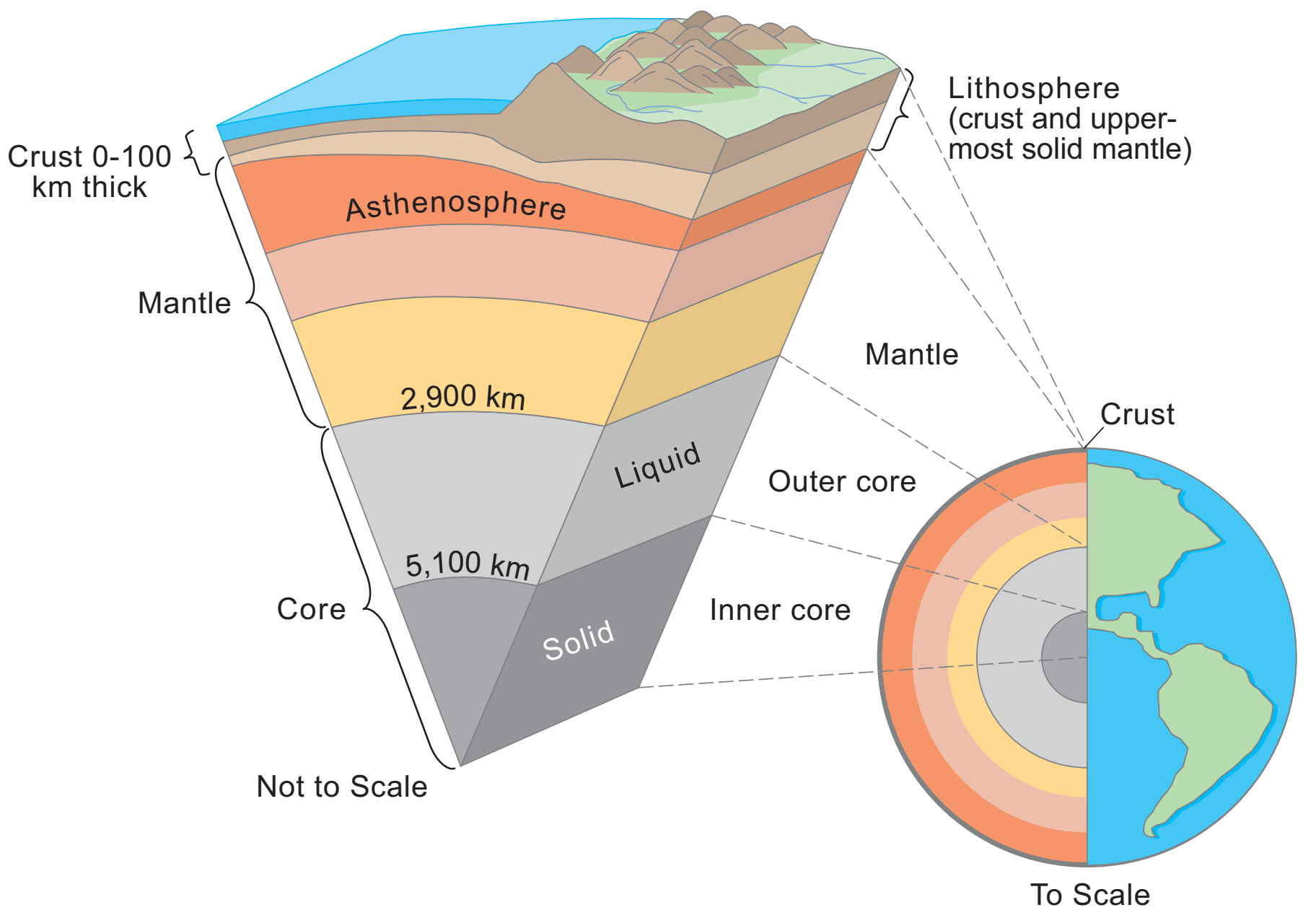

Figure 4. Principal layers of the Earth. The surface is composed of a relatively thin, brittle crust and uppermost solid mantle (lithosphere) that is broken into plates. These plates move slowly over the surface of the Earth. The underlying mantle is a thick, hot, rock layer that deforms like plastic. The core has a liquid outer part and a solid inner part composed of iron and nickel. The Earth's magnetic field is related to the spinning of the core. Figure adapted from Kious and Tilling (1996). Values in $\mathrm{km}$ for depths from surface to major shells 


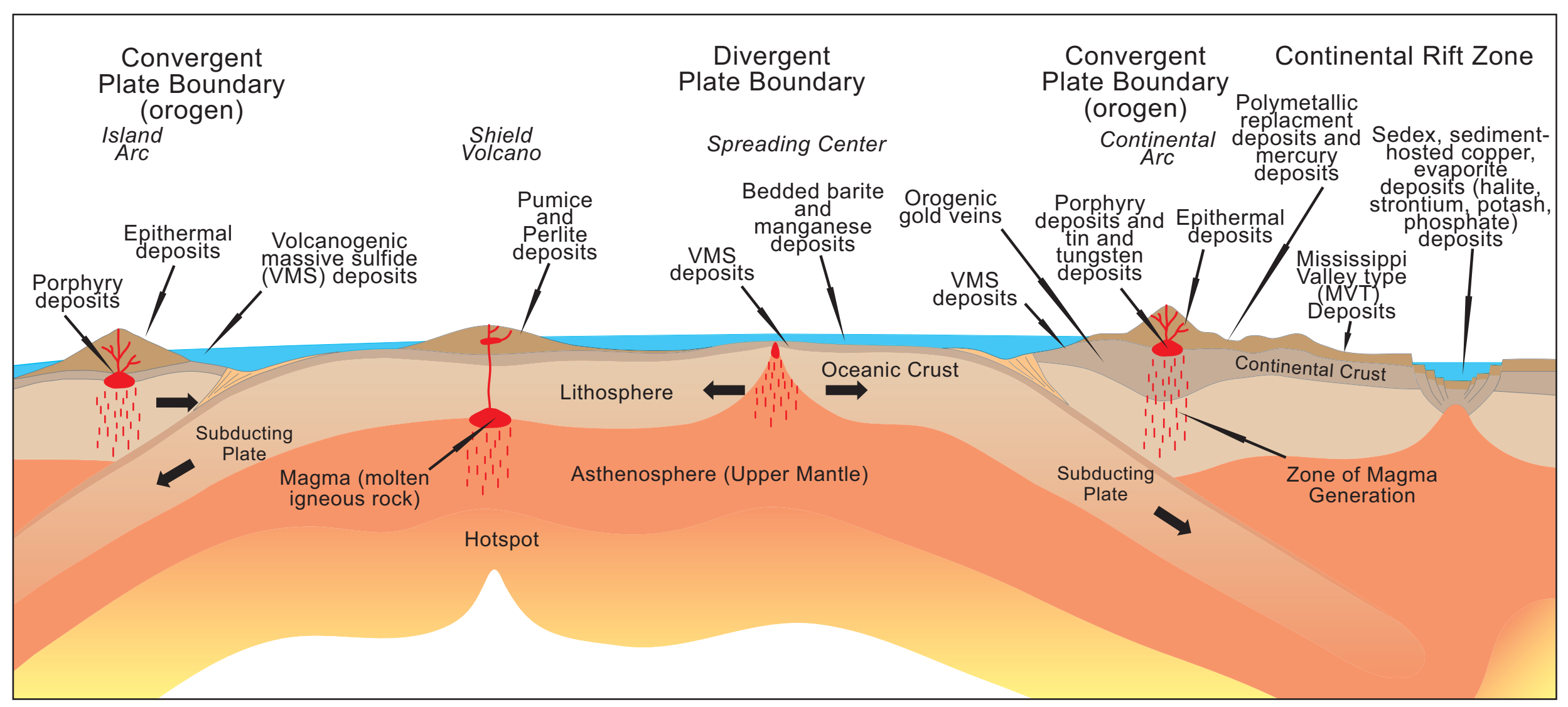

Figure 5. Diagram illustrating the plate tectonic setting in which mineral deposits are formed. The diagram shows a divergent plate boundary (spreading center) where tectonic plates are moving apart from each other and lava flows are extruded on the ocean floor forming a line of undersea volcanoes that encircle the Earth. Iceland, in the mid-Atlantic, is the tip of one part of this mountain range. Volcanogenic massive sulfide (volcanogenic massive sulfide) deposits (described in the text) are an example of mineral deposits that form on the sea floor. Also shown are convergent plate boundries where an oceanic plate is being subducted beneath a continental tectonic plate forming folded and faulted mountains (deformational beltss) with stratovolcanoes. An example is the Kamchatka volcanic arc in the Russian Far East. The subduction of oceanic tectonic plates is accompanied by strong earthquakes and the generation 


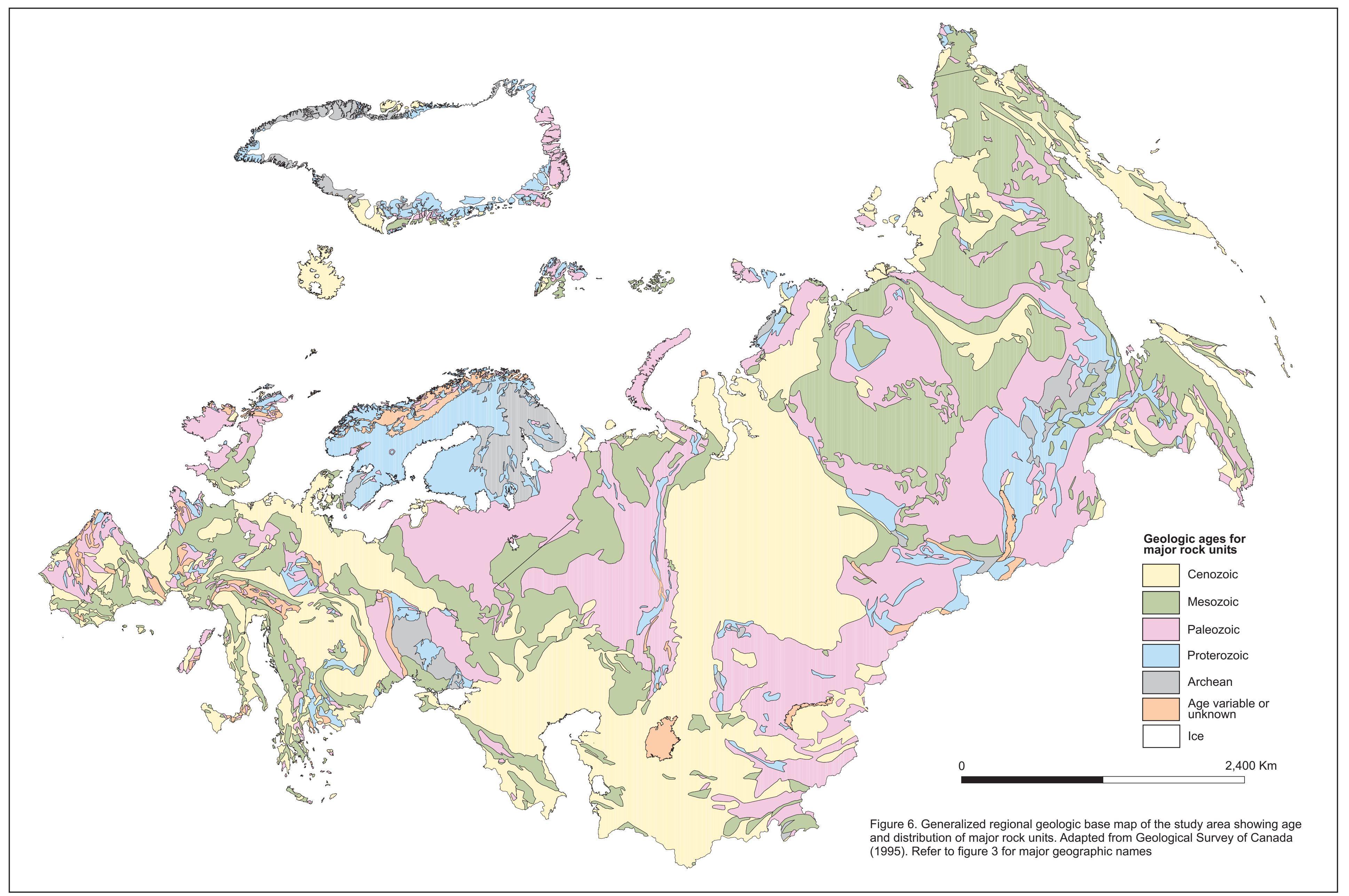




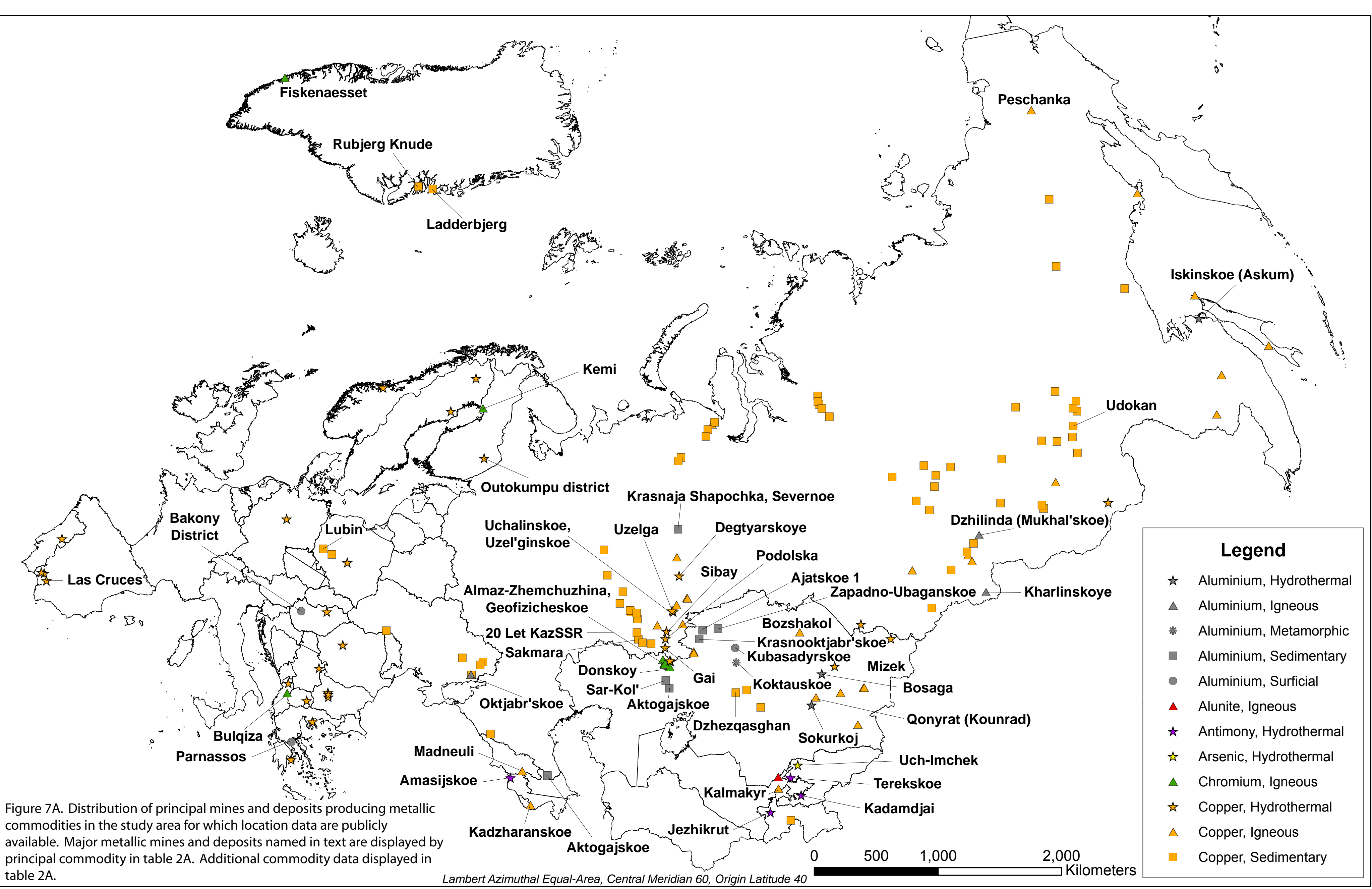




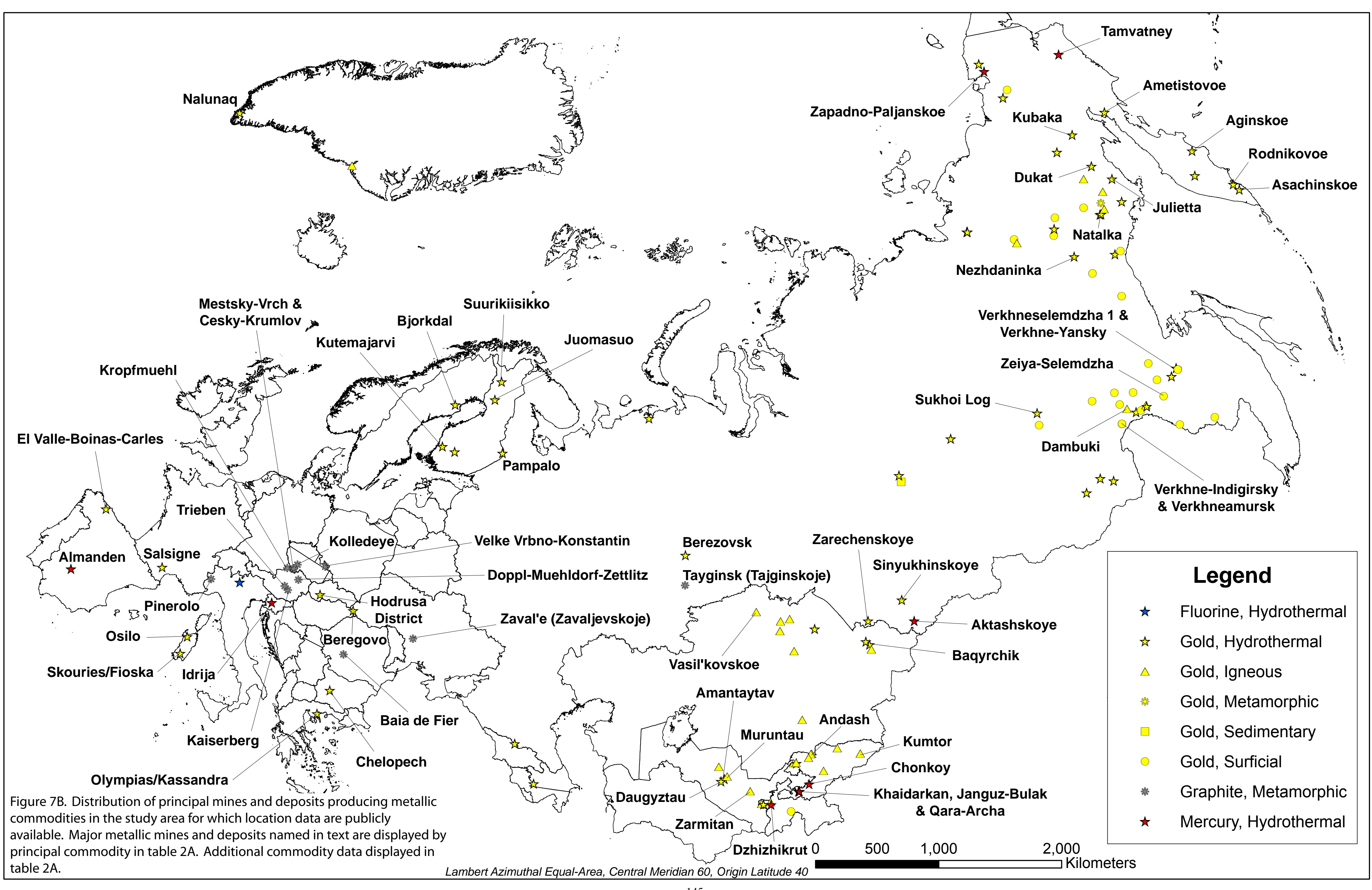




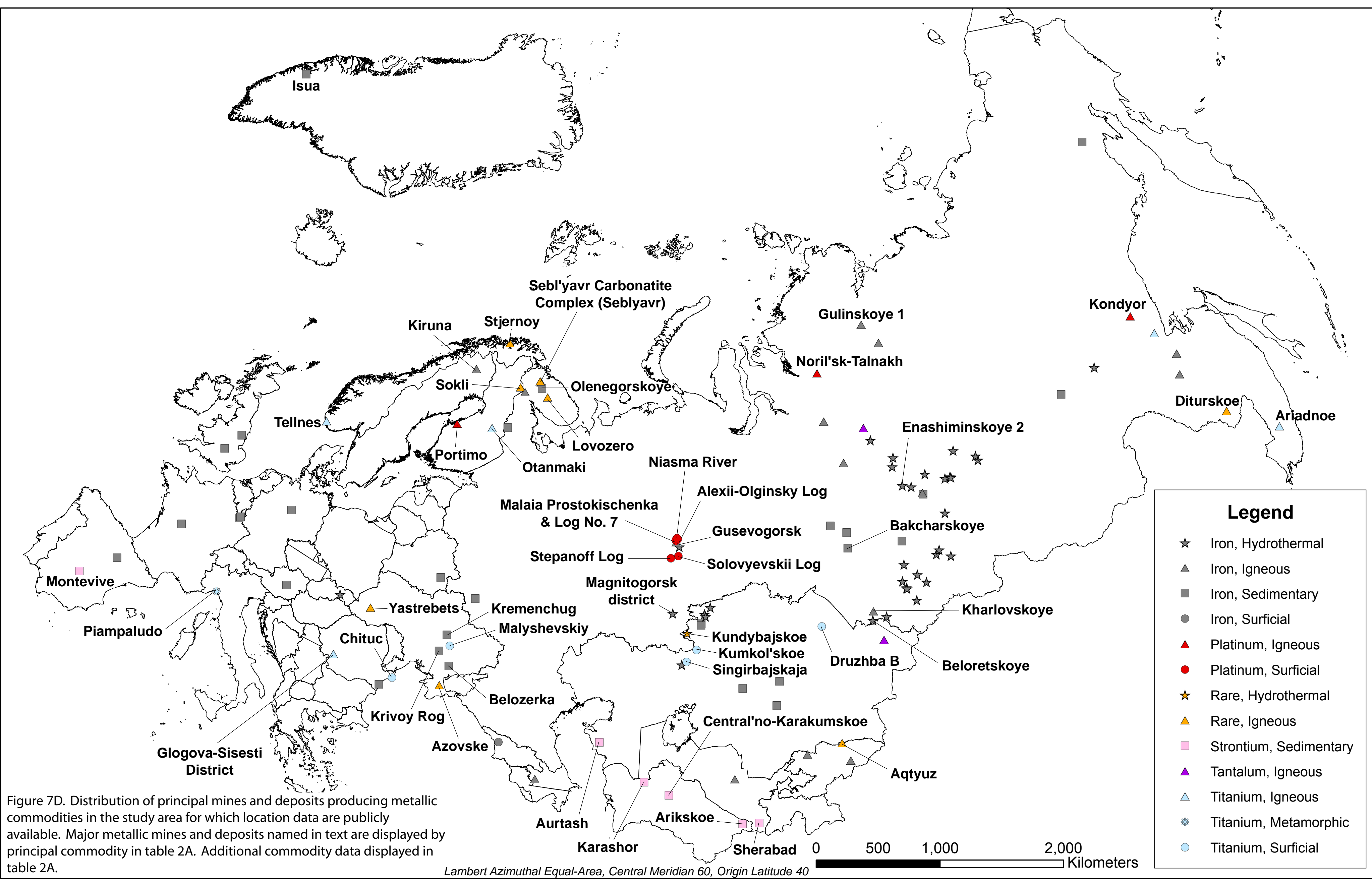

principal
table 2A.

Lambert Azimuthal Equal-Area, Central Meridian 60, Origin Latitude 40 


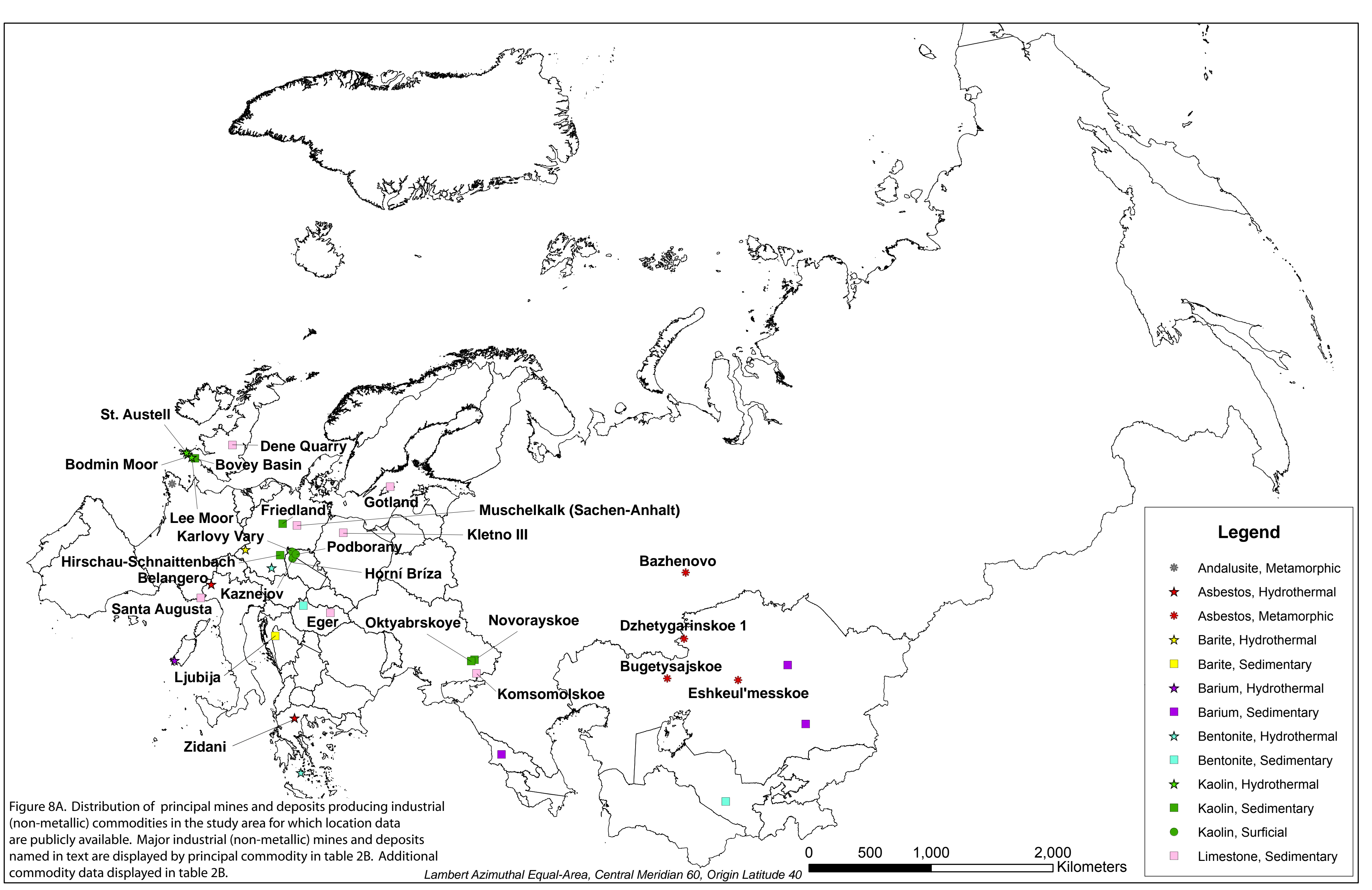




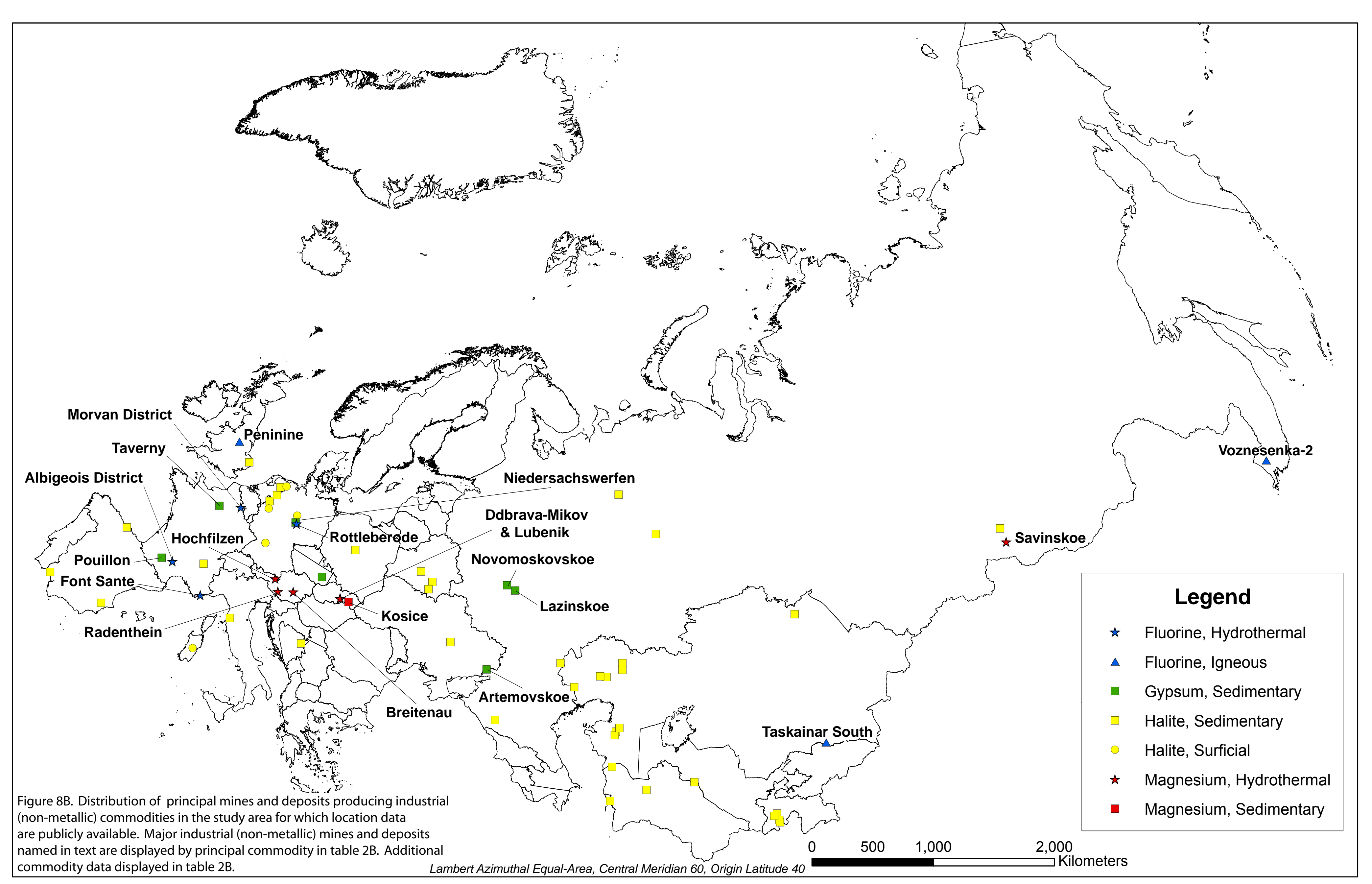




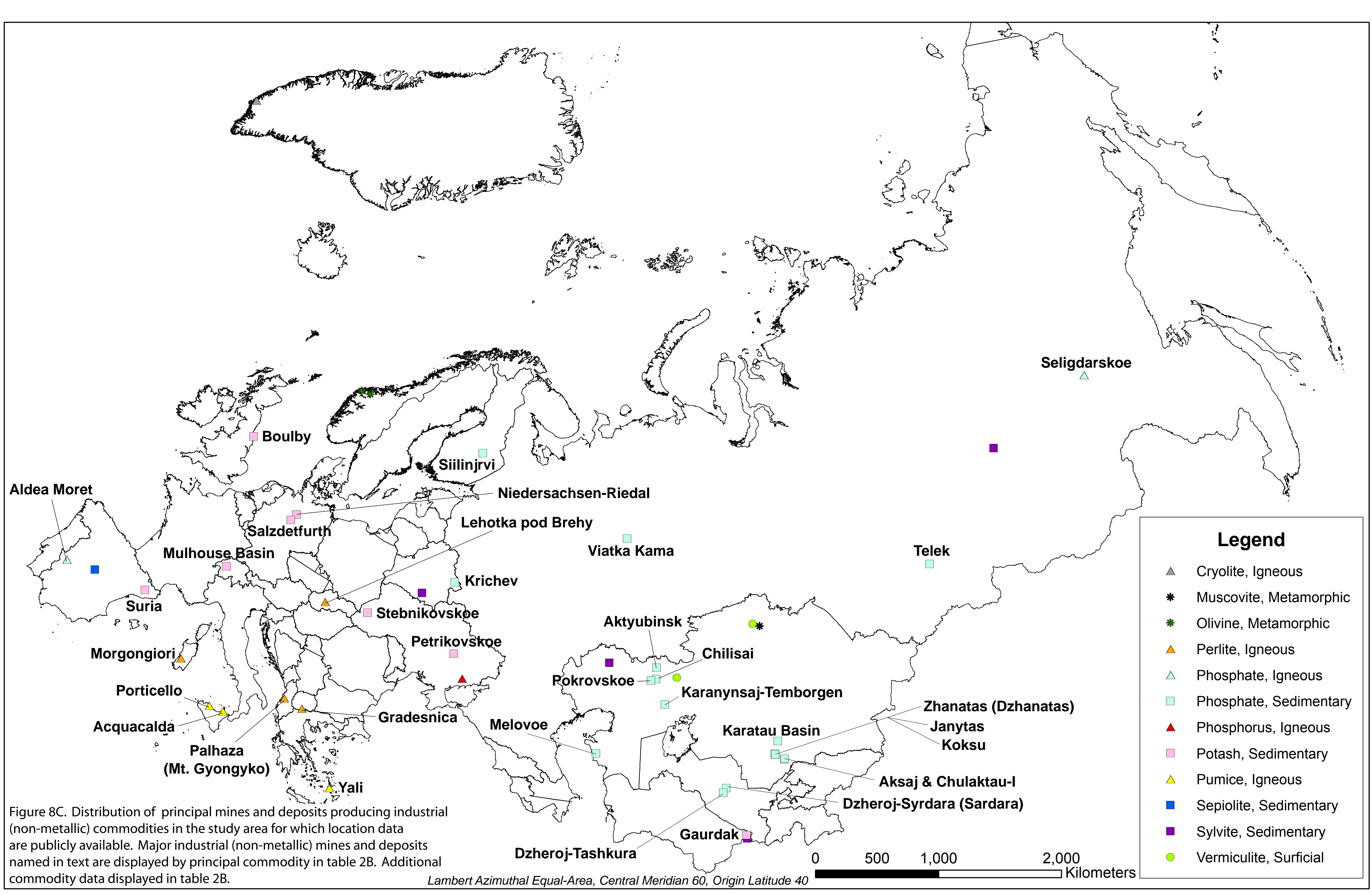




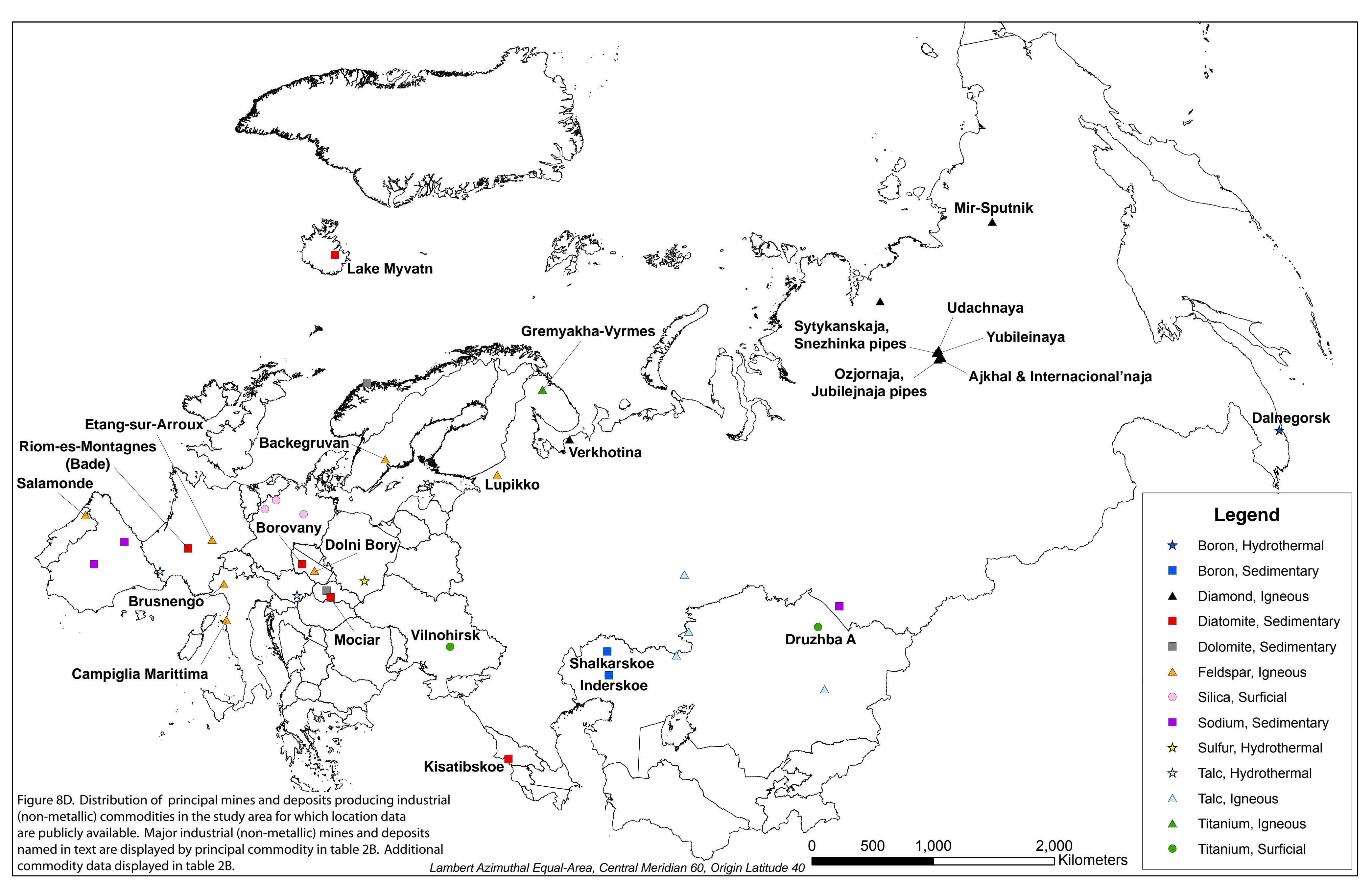




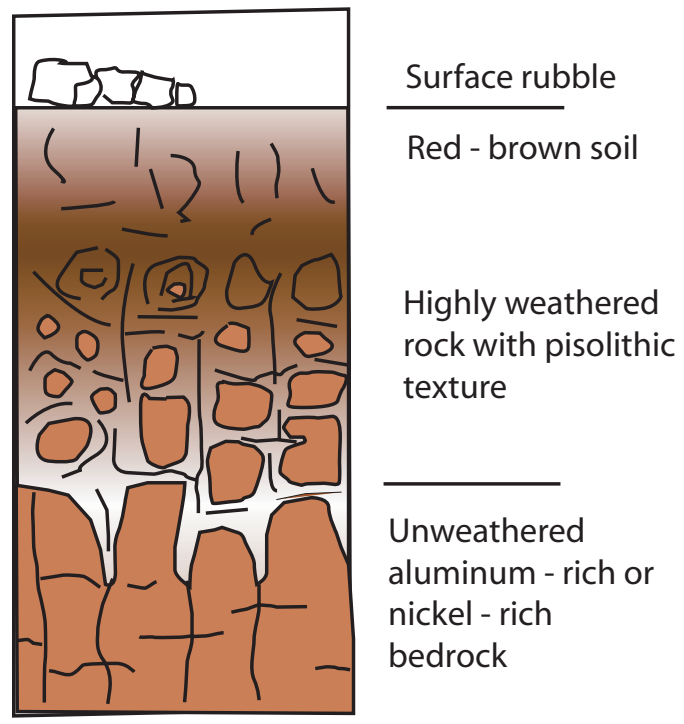

Figure 9. Schematic laterite profile showing the progression of weathering effects on rock. Some commodities, such as aluminum, iron, and nickel, are enriched by weathering. Adapted from Elias (2002). 


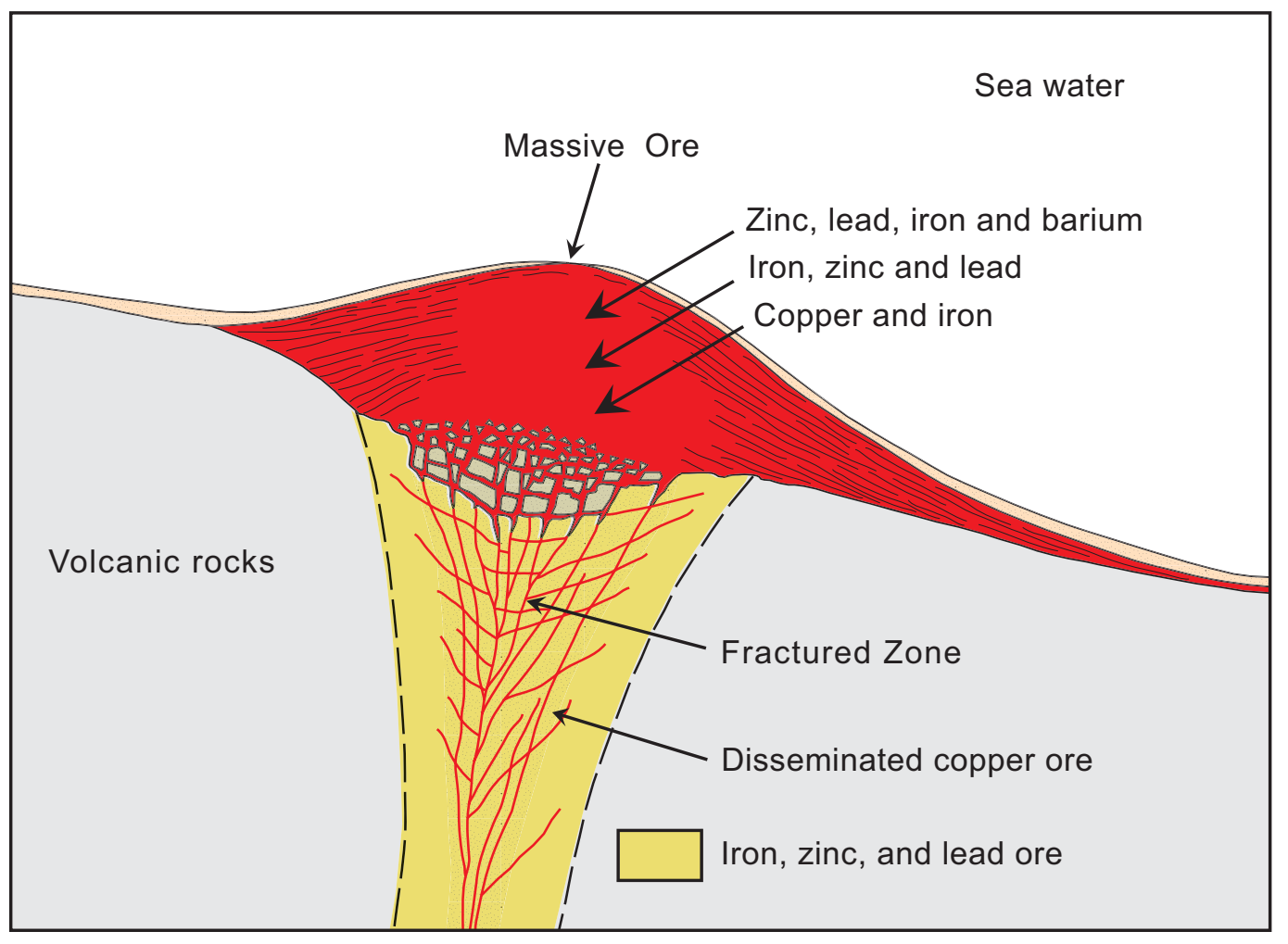

Figure 10. Schematic cross section illustrating the characteristic features of volcanogenic massive sulfide deposits. Hydrothermal fluids move upwards along fractures in volcanic rocks towards open water. When the hot hydrothermal fluids vent and mix with cold ocean water, iron, copper, lead, and zinc veins, gold-silver veins, and sulfur deposits, and zinc sulfide minerals form and collect as a mound on the sea floor. Ore minerals also can form in the fractures underlying the mound of sulfide minerals. 


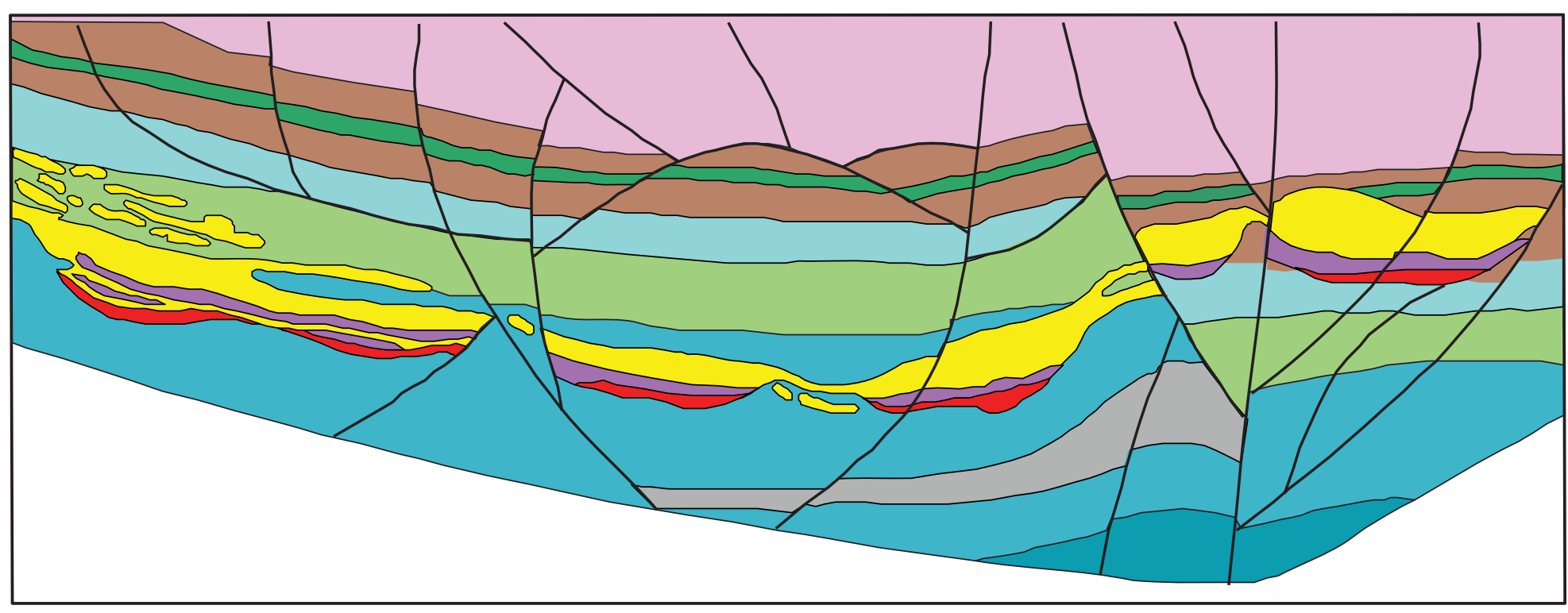

Host Sedimentary and Volcanic Rocks -

\section{Early and Middle Paleozoic}

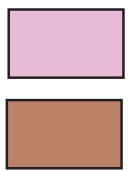

Mafic volcanic rock

Tungus series- terrigenous sedimentary rock and coal, late Palēozoic

Carbonate rock, middle Paleozoic

Sulfate and carbonate rock, middle Paleozoic

Terrigenous, carbonate, and sulfate rock, middle Paleozoic -

Carbonate rock, early to middle Palezoic
Talnakh Intrusion -

\section{Early Triassic}

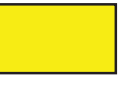

Marginal gabbro and local igneous breccia

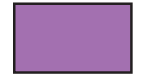

Gabbro with disseminated copper-nickel sulfide ore

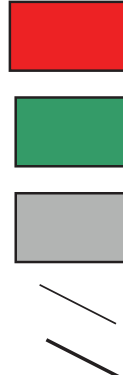

Massive copper-nickel sulfide ore

Fine-grained marginal gabbro

Lower Talnakh intrusion

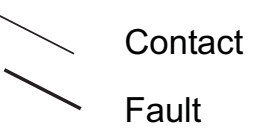

Figure 11. Schematic east-west longitudional cross section of Talnakh intrusion at Norilsk-Talnakh copper-nickel-PGE (platinum group elements) sulfide deposit, northern Siberia, Russia. Deposit hosted in mafic and ultramafic igneous rock. Copper, nickel, and PGE minerals occur as masses and as disseminations (widely spaced minerals) in gabbro and ultramafics rock. Scale not provided by authors. Adapted from Duzhikov and others (1992). 


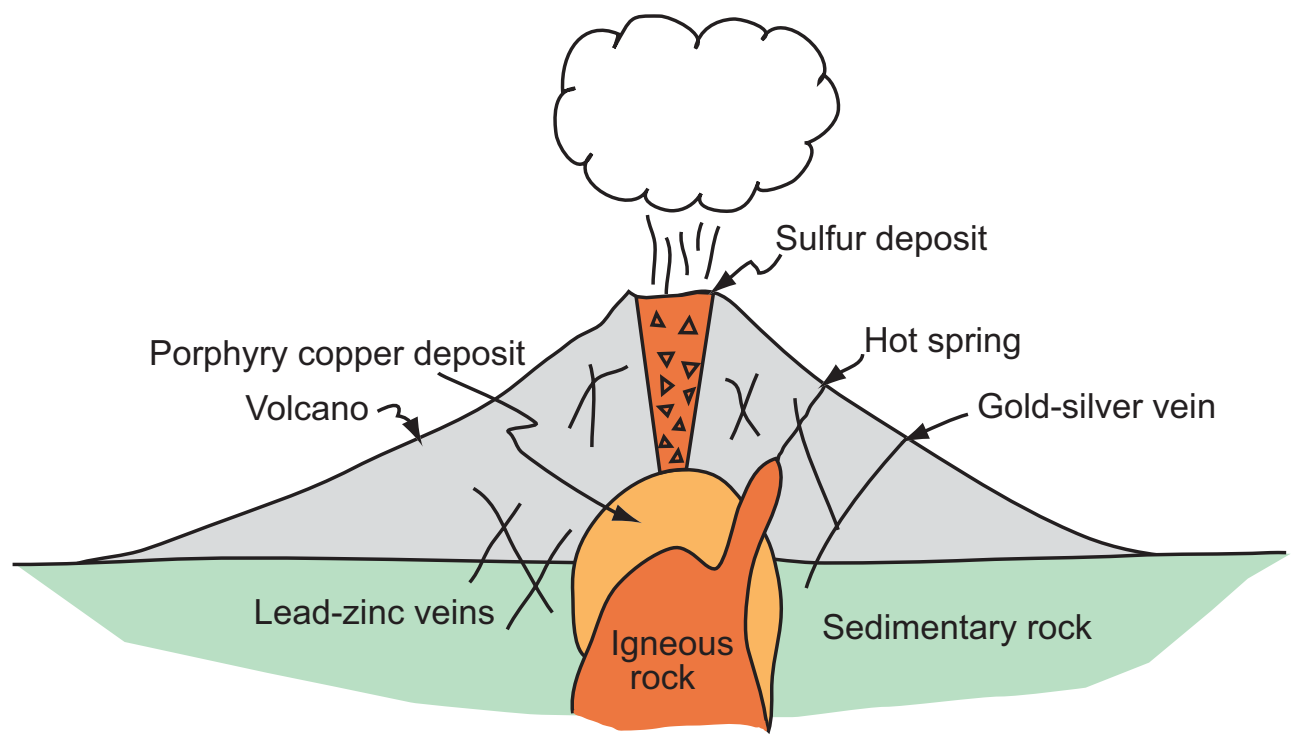

Figure 12. Cross section of a stratovolcano showing the relative locations of porphyry copper deposits, lead and zinc veins, gold-silver veins, and sulfur deposits. Adapted from Cunningham and others (this volume). 


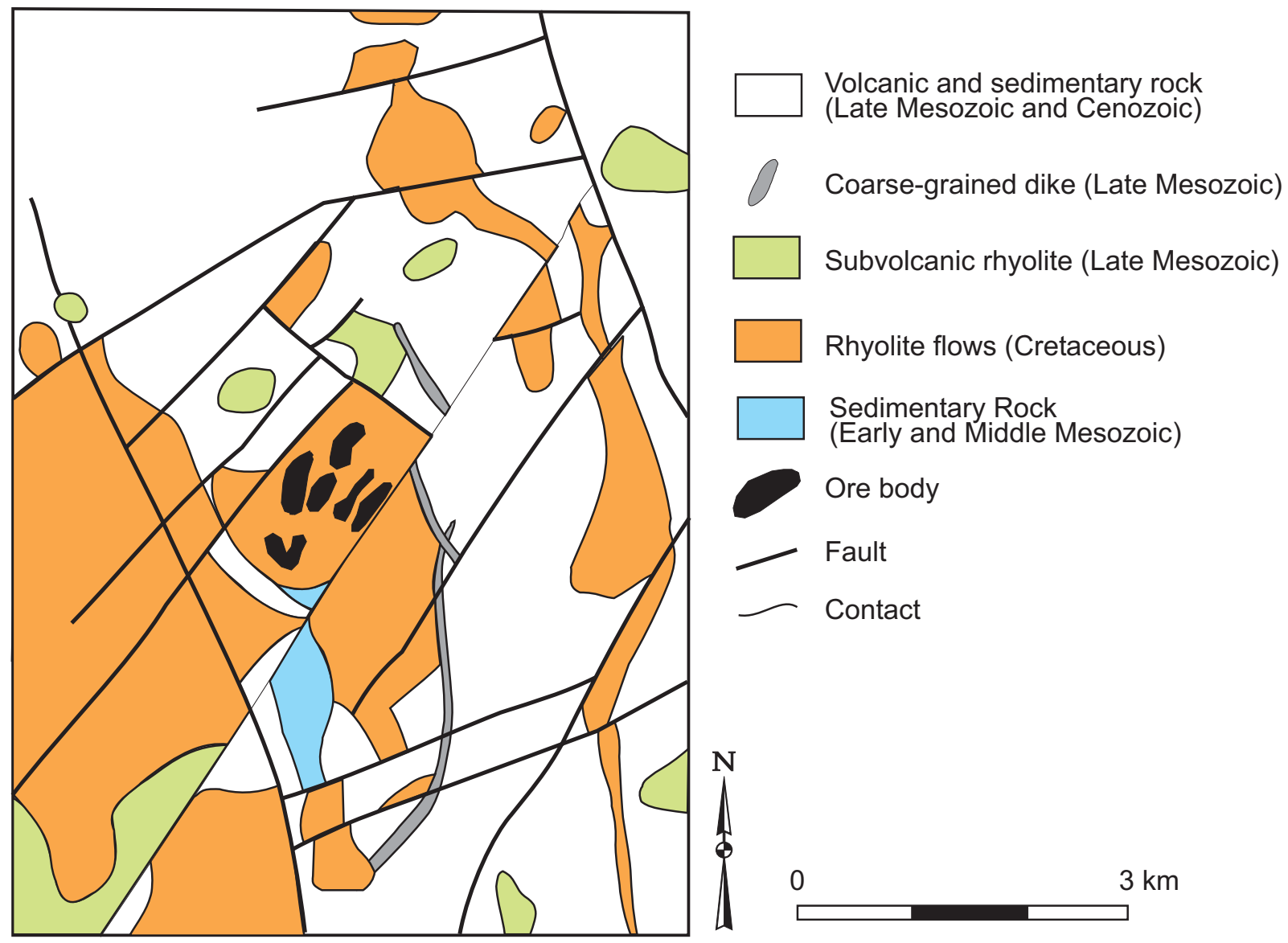

Figure 13. Schematic geologic map of the Dukat gold-silver epithermal vein deposit, Russian Northeast. The gold and silver occur in the ore zone in hydrothermally altered rhyolite flows. Adapted from Goncharov (1995). 


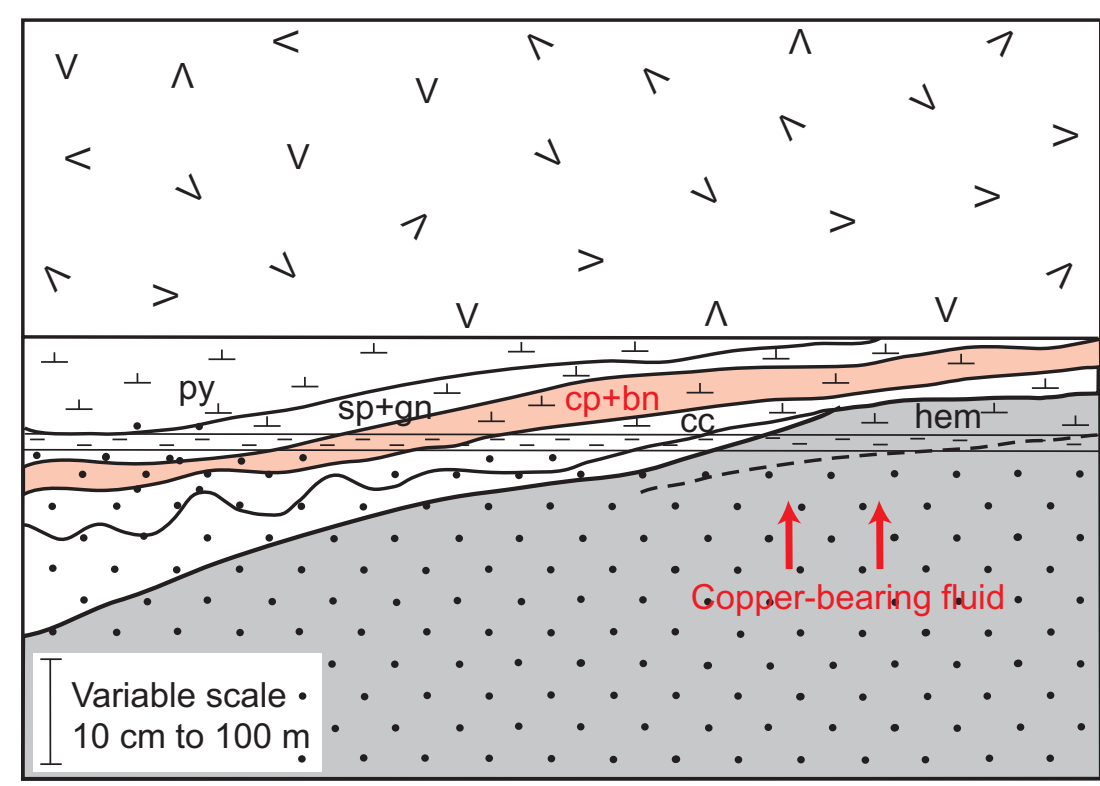

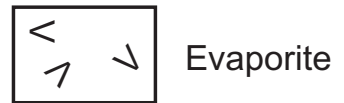
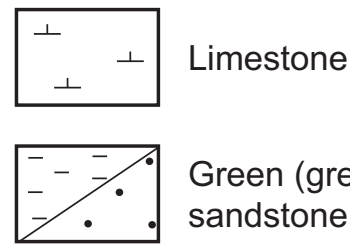

Green (grey) mudstone sandstone
Mineral Abbreviations

bn bornite

cc chalcocite

cp chalcopyrite

gn galena

hem hematite

py pyrite

$\mathrm{sp}$ sphalerite

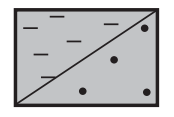

Red mudstone and sandstone

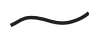

Mineralogical zone boundary

$\uparrow$

Flow direction of cupriferous formation water

Figure 14. Schematic cross section of Kuperscheifer-type sedimenthosted copper deposit. The copper minerals (chalcopyrite, bornite), along with pyrite (iron sulfide), sphalerite (zinc and iron sulfide), galena (led sulfide), and hematite (iron oxide) in stratabound layers that are mostly parallel to major sedimentary rock layers that form in an evaporite basin. Adapted from Kirkham (1995). 


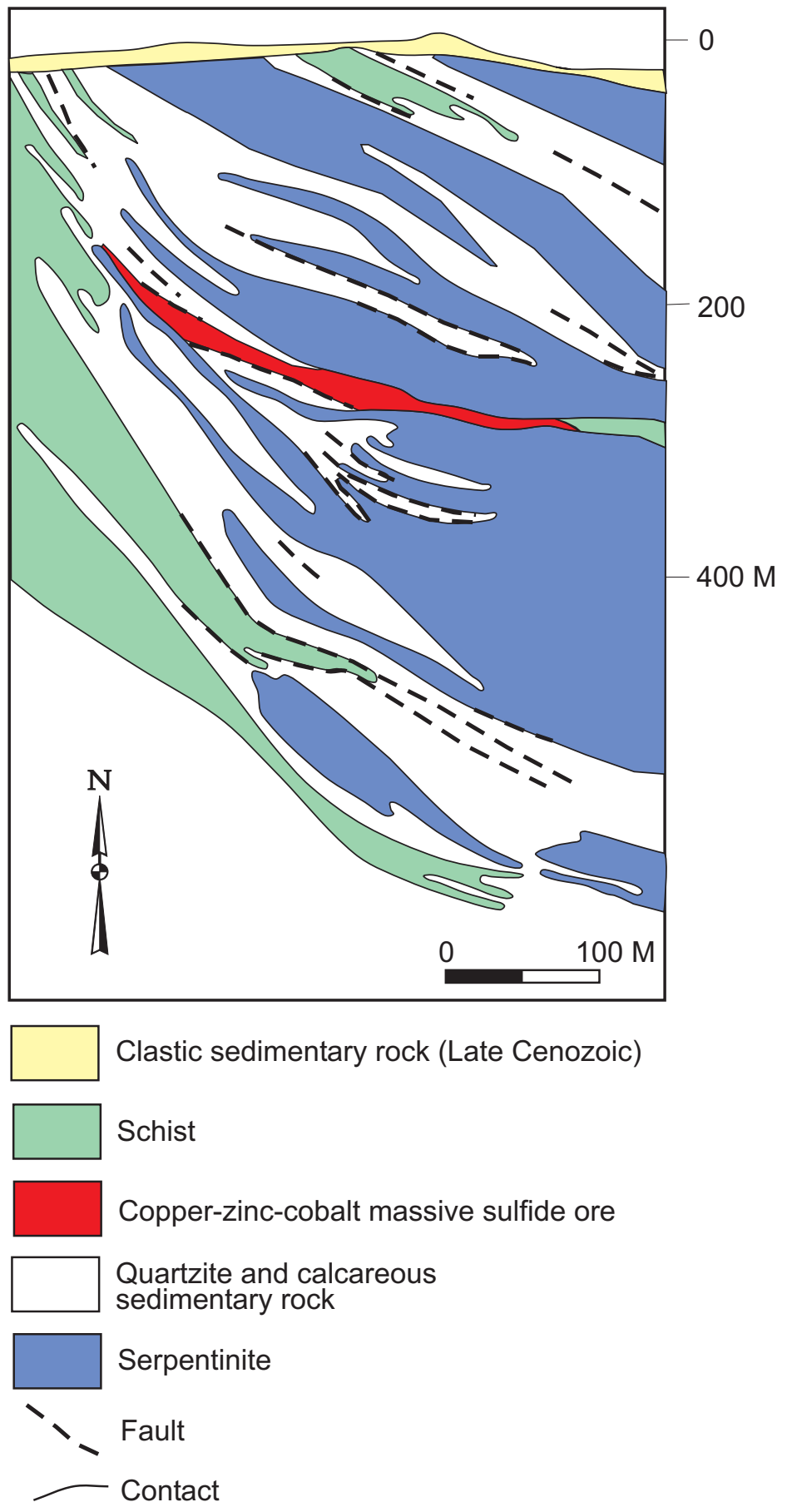

Figure 15. Schematic cross section of the Keretti Mine, Outokumpu, Finland. Copper-zinc-cobalt minerals occur as large masses in and adjacent to highly-deformed serpentinite (hydrothermally-altered mafic (magnesium- and iron-rich) igneous rock. Adapted from Gaal and Parkkinen (1993). 


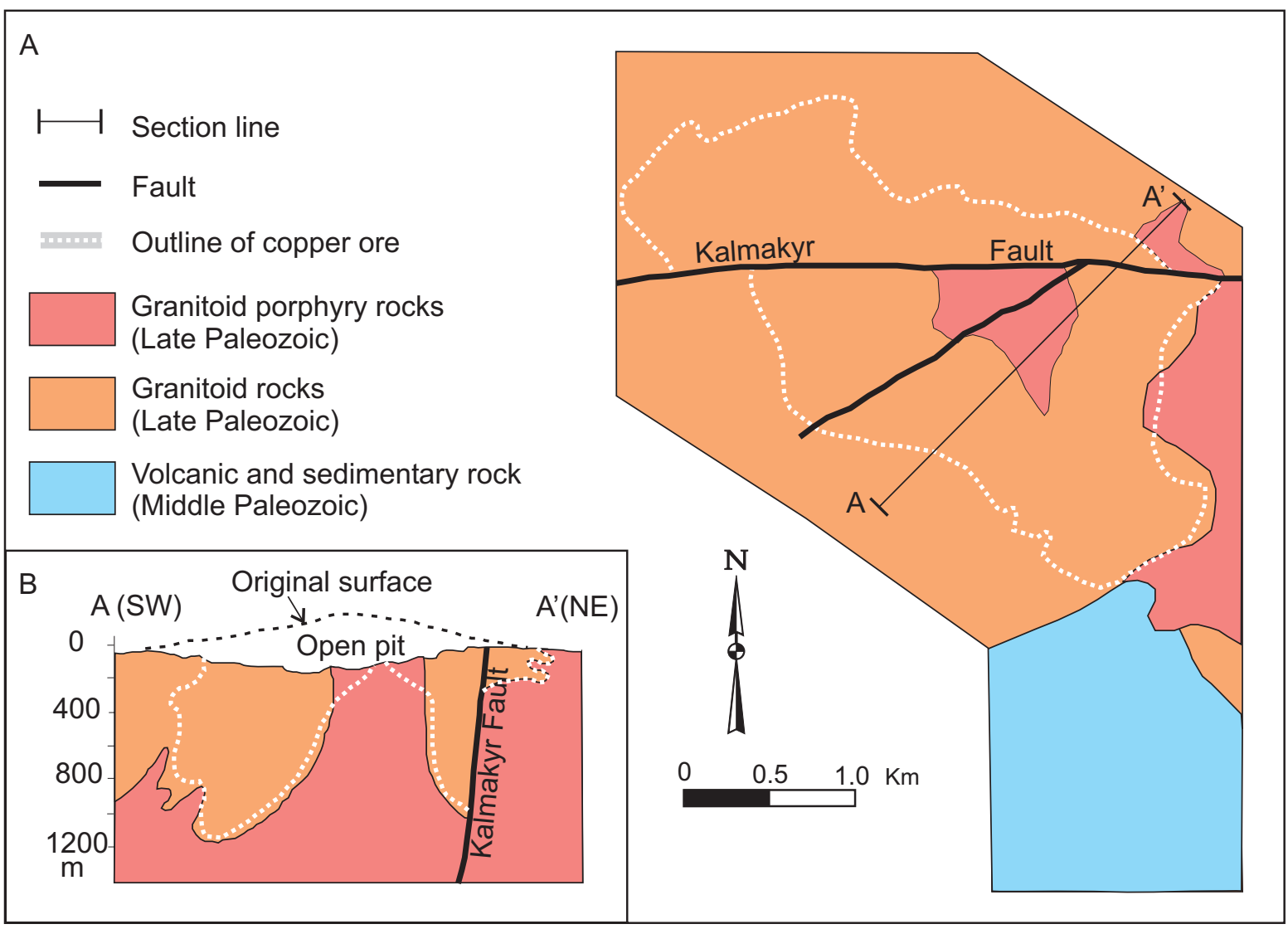

Figure 16. Schematic geological map (A) and geological section (B) of the world-class Kalmakyr copper deposit related to granitic intrusions (porphyry copper deposit), Uzbekistan. The cooper minerals occur mainly as disseminations (widely spaced minerals) in hydrothermally-altered granite. Adapted from Shayakubov and others (1999). 


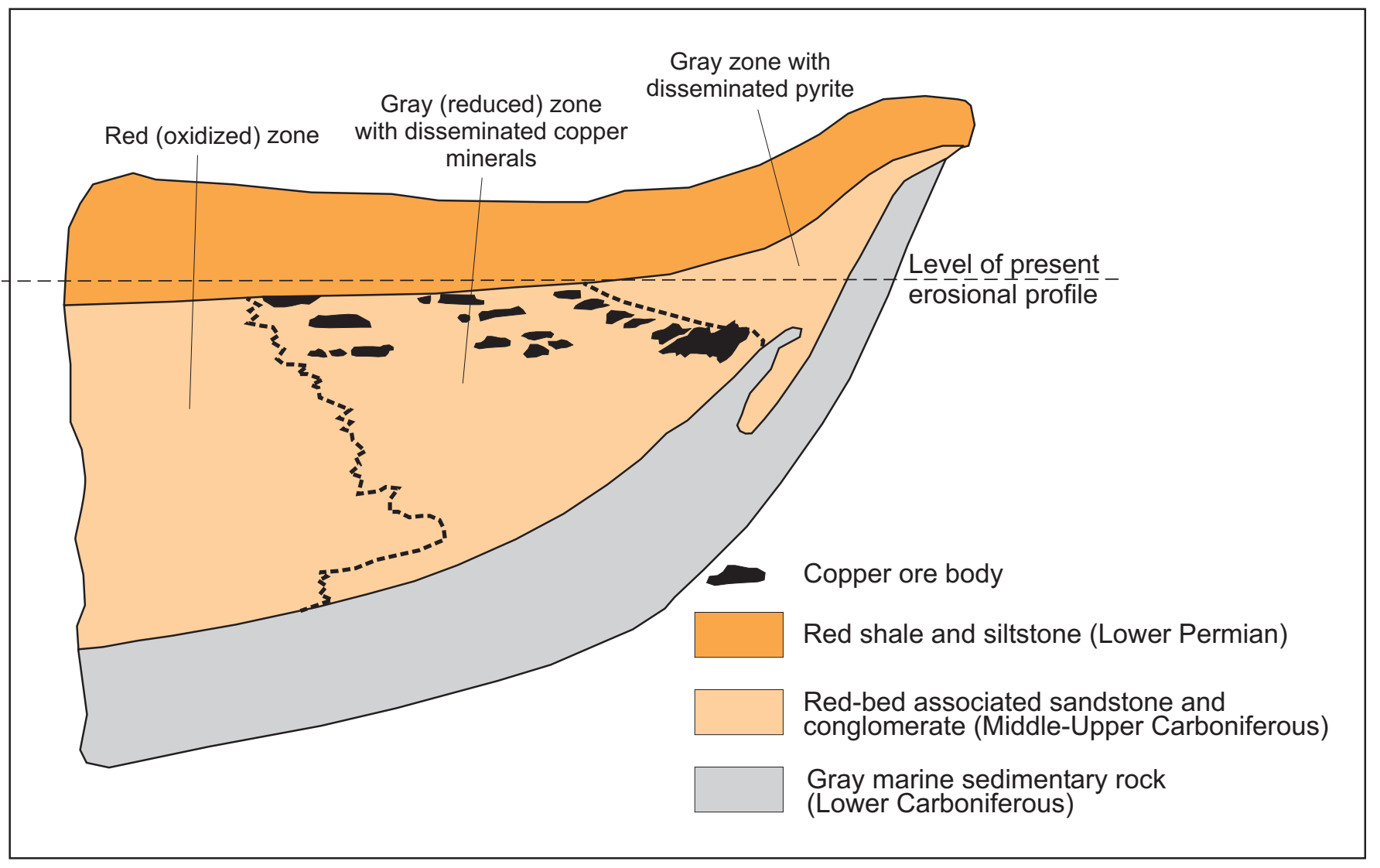

Figure 17. Schematic cross section of the Dzhezkazgan sediment-hosted copper deposit in Kazakhstan. The copper minerals occur in red-bed sandstone and conglomerate. Modified from Gablina (1981). 


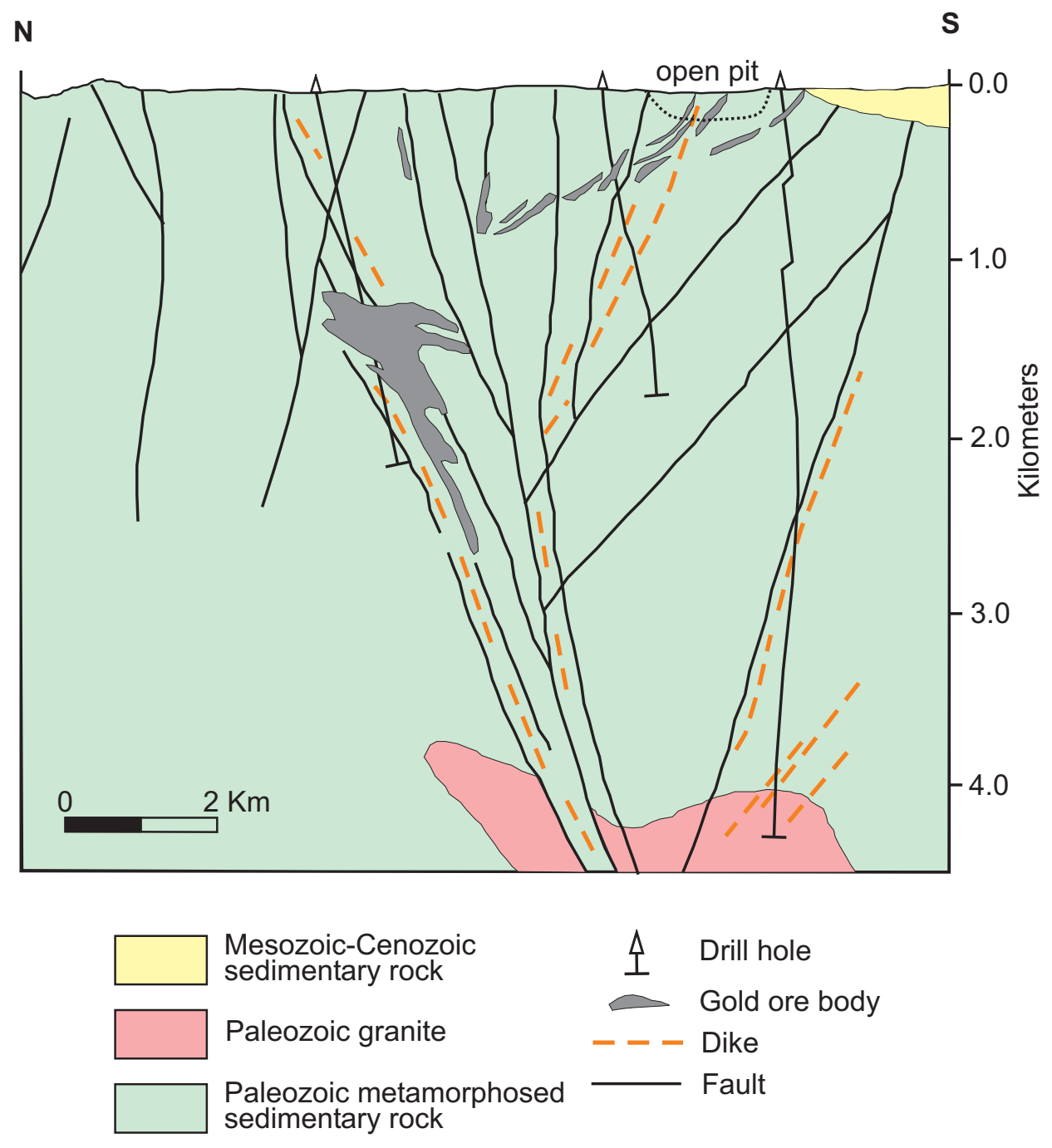

Figure 18. Geological section across the eastern part of the Murantau gold district, Uzbekistan, along the profile of deep drill holes. Gold deposits occur along, but crosscut major faults. Modified from Shayakubov and others $(1999$ 


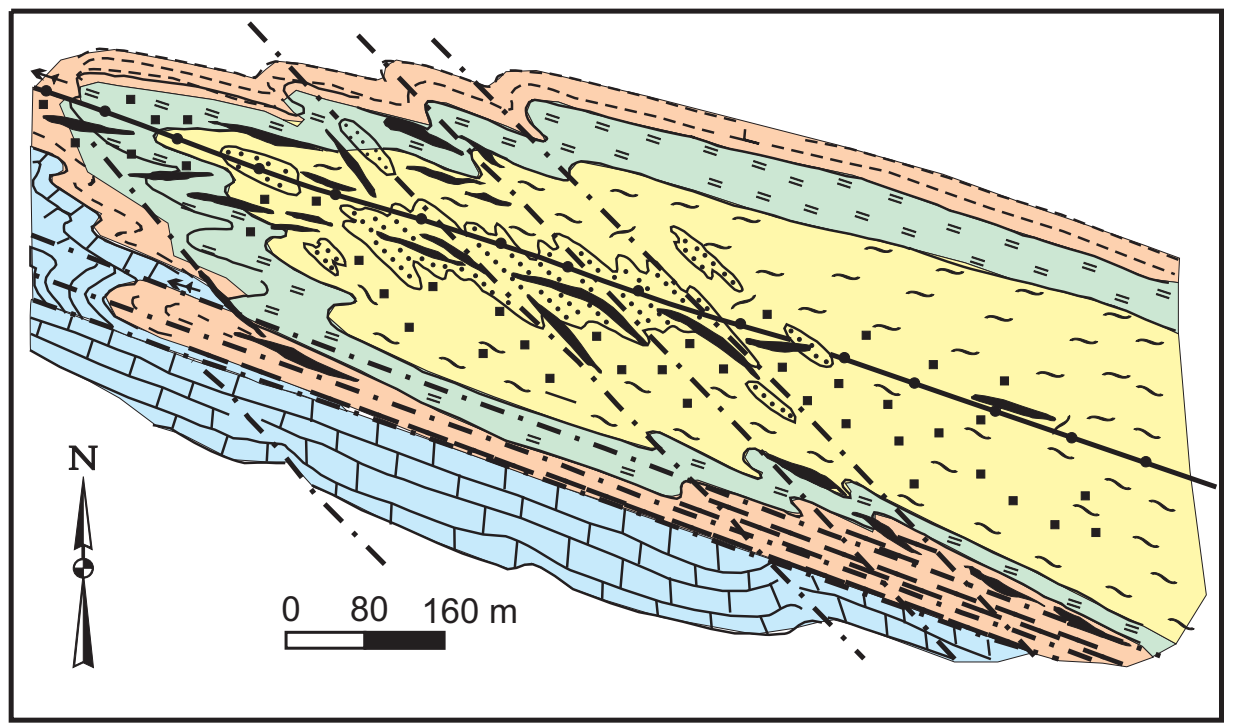

Patom Series (Late Proterozoic)
Limestone and carbonaceous

Khomolkho Suite (Late Proterozoic)

$E=: ニ=$ Siltstone and sandstone

$==$ Carbonaceous phyllite

Quartz vein

$\because \quad$ Intense pyrite alteration

Halo of gold-quartz-sulfides

Axial line of Sukhoy Log anticline

- Fault

$=\quad=$ and siltstone

$\sim$ Carbonaceous sheared shale

Figure 19. Schematic geologic map of the Sukhoy Log black-shale-hosted gold deposit, southern Siberia, Russia. Quartz-sulfide halos occur around major quartz veins and major faults. Adapted from Buryak (1980). 


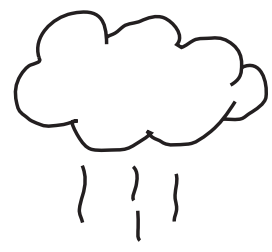

Rain

Gold in quartz veins

Rounded quartz pebbles
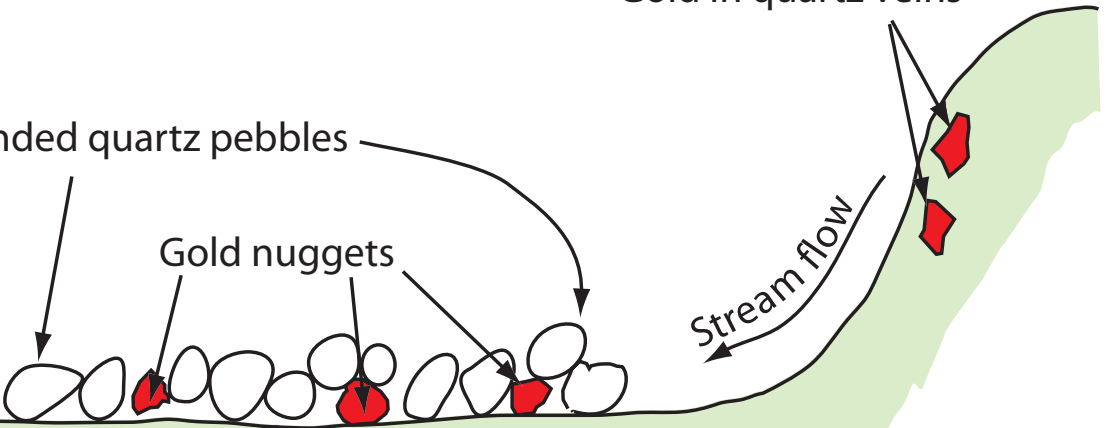

Placer Gold Deposit

Figure 20. Formation of placer gold deposikts and related placer titanium and platinum-group element (so-called heavy mineral) deposits. Gold in veins and other heavy mineral deposits exposed at the surface are eroded where running water concentrates the heavy gold nuggets or other heavy metals in streams. These deposits form because of the high density of the heavy minerals, and can be prospected with a gold pan or commercially mined on with a dredge. 


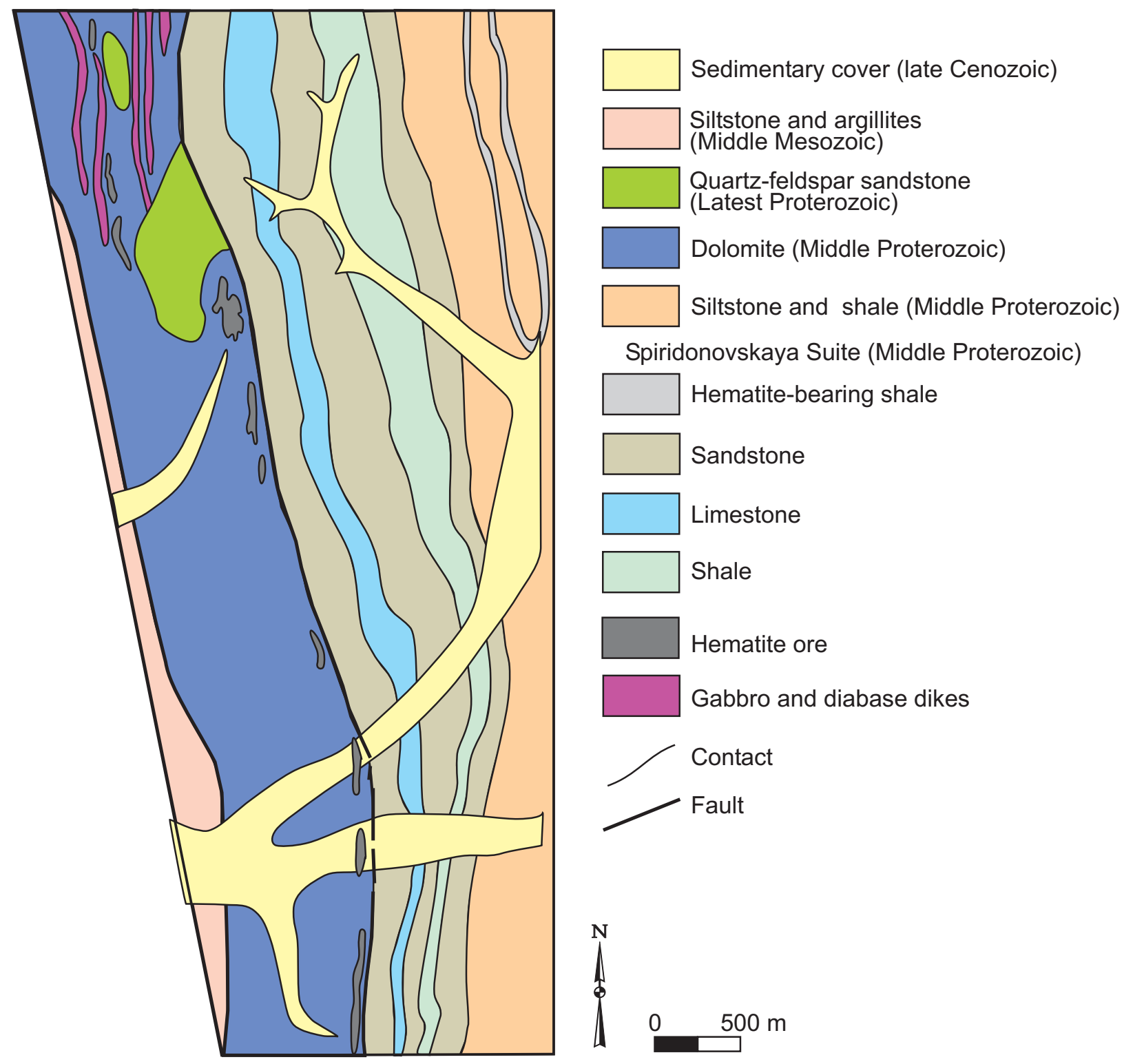

Figure 21. Schematic geologic map of the Pobeda ironstone deposit, Russian Northeast. Ironstone occurs in major sedimentary rock units. Adapted from Shpikerman (1998). 
Sea water

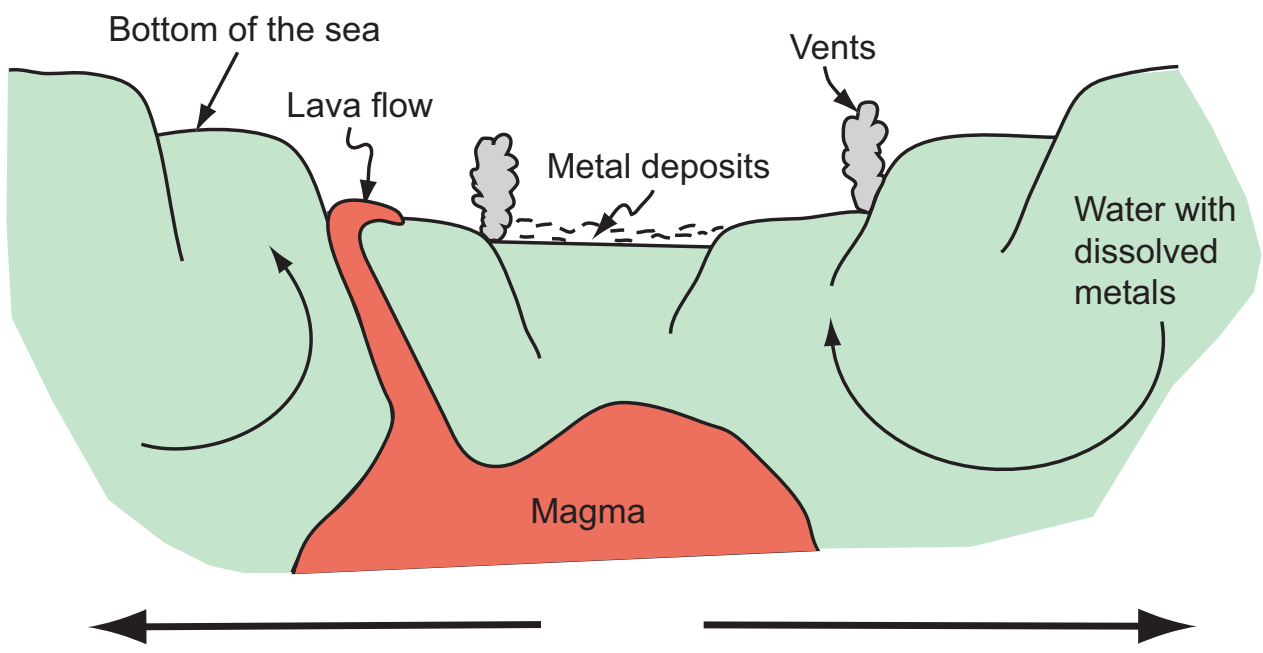

Figure 22. Schematic diagram of an oceanic extensional tectonic (rift) setting where plates are moving away from each other. Magma migrates up cracks and erupts to form submarine lava flows on the sea floor. The heat from the magma causes hydrothermal fluids (hot, salty water containing dissolved metals) to circulate in fractures in the rocks. The metal-bearing hydrothermal fluids react with the sea water and deposit metals to form mineral deposits. 


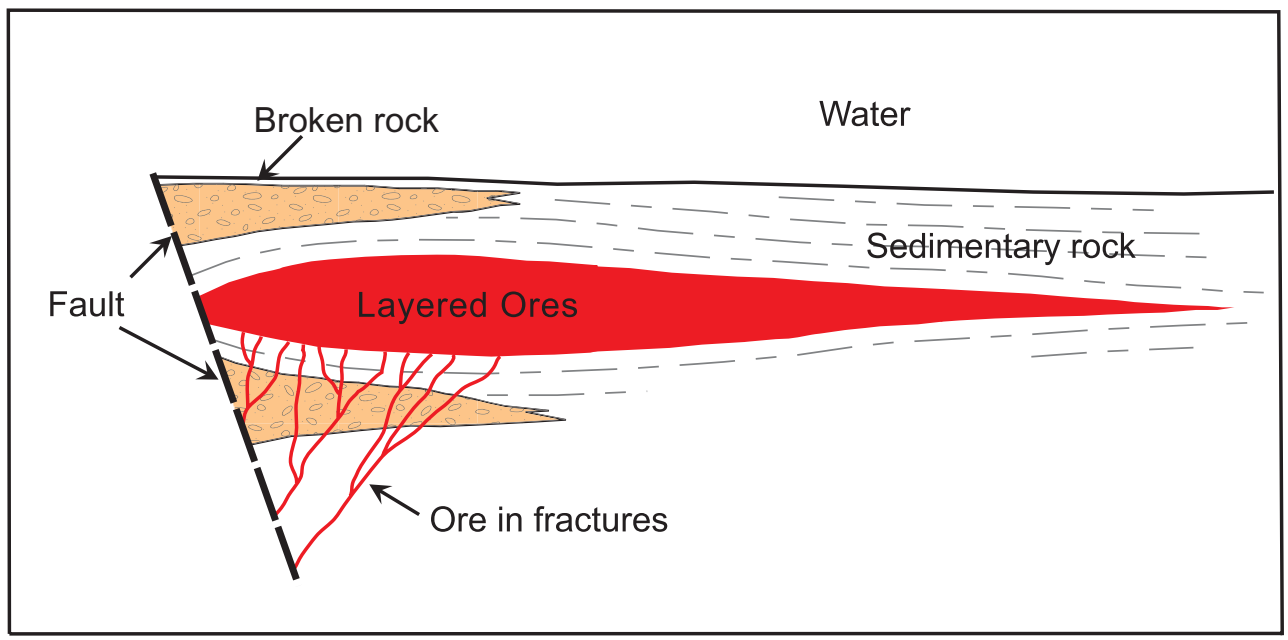

Figure 23. Schematic cross section illustrating the characteristic features of sedimentary exhalative lead and zinc deposits. The fault is active during accumulation of the sediments and the ore minerals. Hydrothermal fluids move upwards along the fault and other fractures towards open water. Beds of broken rock form near the active fault by erosion of fault scarps or by explosions related to the venting of hydrothermal fluids into open water. Bedded ores consist of iron, lead, and zinc sulfide minerals that formed at or near the bottom of the sea from hydrothermal fluids that vented into open water from faults and fractures. Ores in fractures consist of iron, lead, and zinc minerals that were deposited by hydrothermal fluids moving through sediments. Modified from Lydon (1996). 


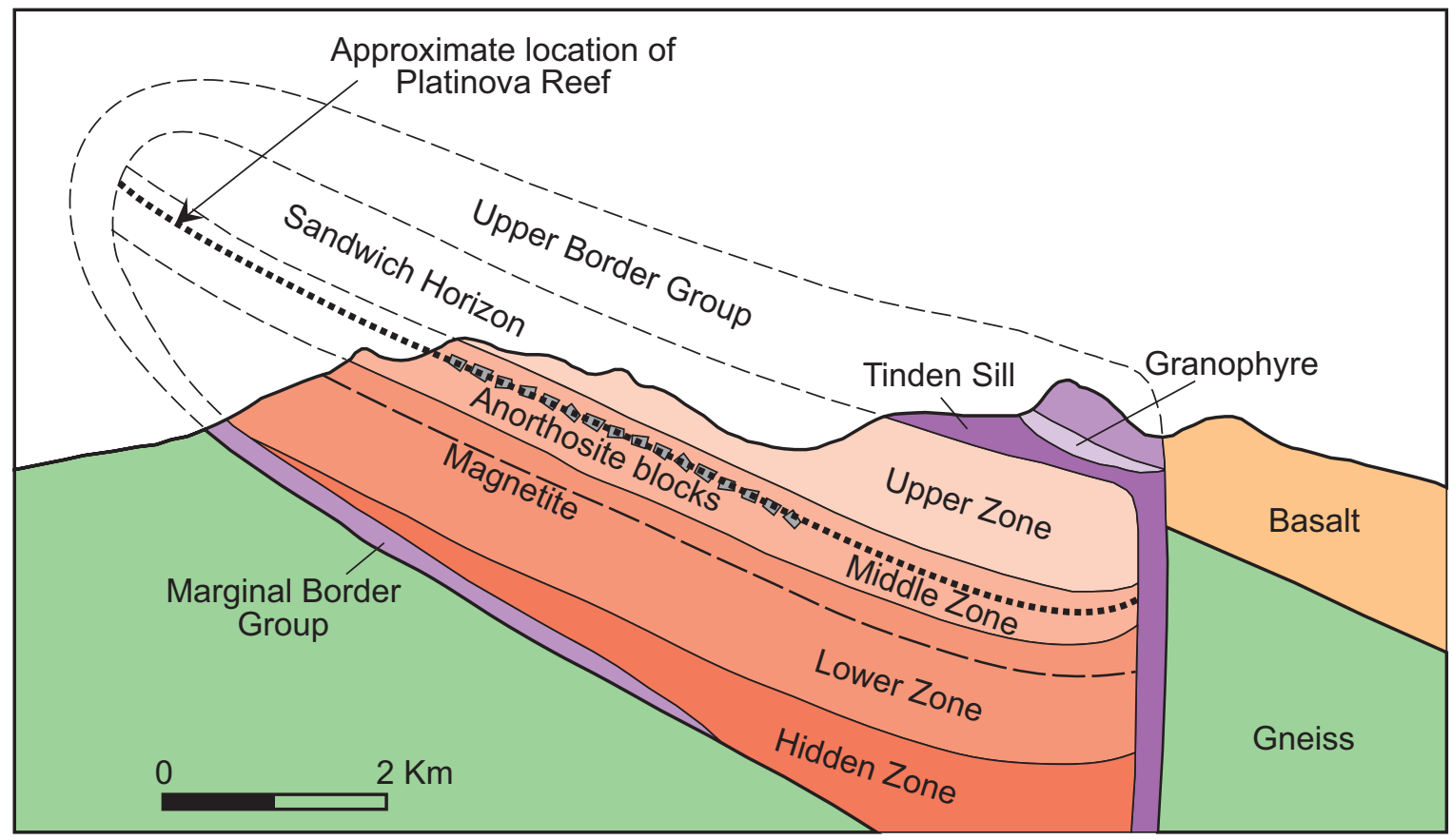

\section{Eocene flood basalt}

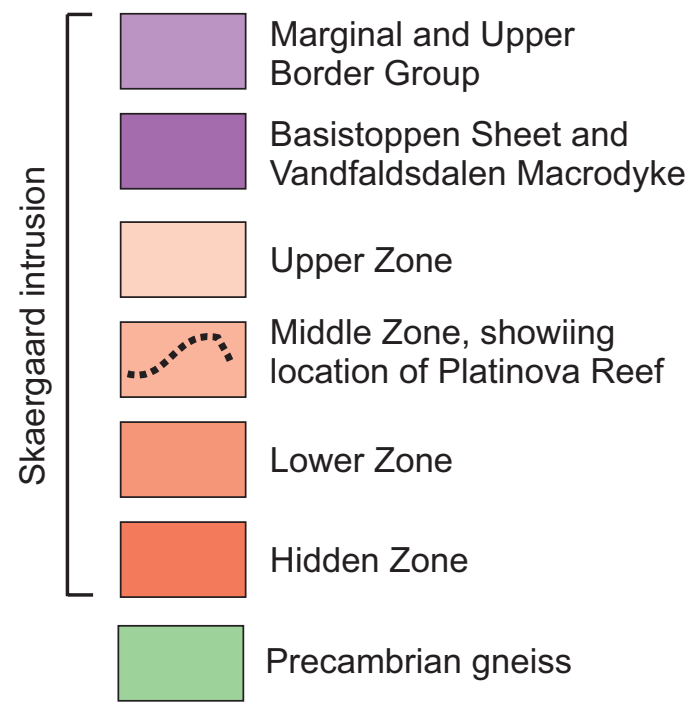

Figure 24. Schematic reconstructed north-south cross section of the Skaergaard intrusion showing the approximate location of the Platinova Reef. The platinum-group elements occur as sedimentary layers in the Platinova Reef in the layered mafic (magnesium- and iron rich) pluton. Adapted from Nielsen (1989). 

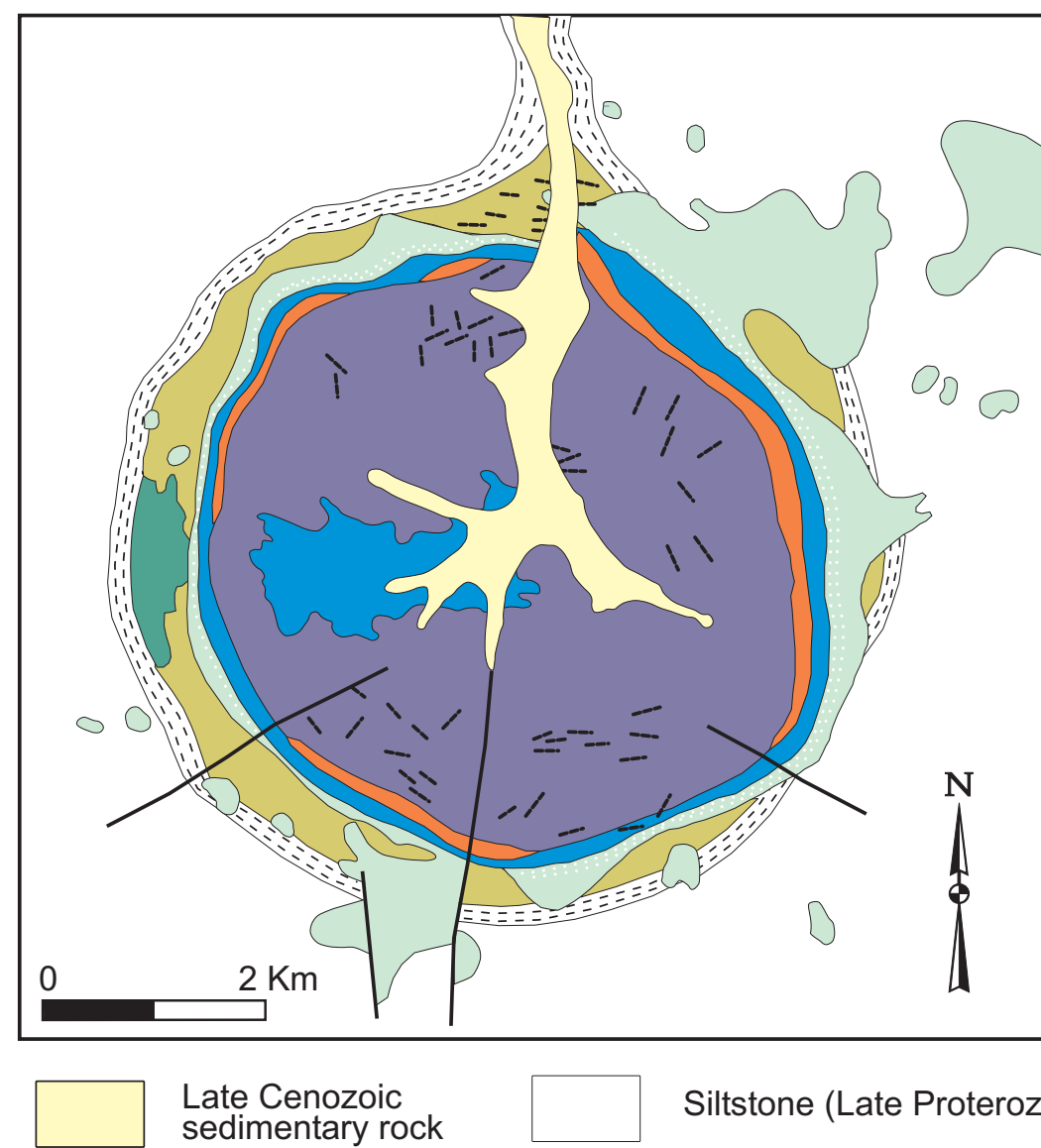

Late Cenozoic sedimentary rock

Kondyor pluton

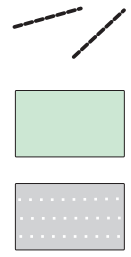

Pegmatite

Diorite

Light diorite

Pyroxenite and amphibolite

Siltstone (Late Proterozoic)

Siltstone and sandstone (Late Proterozoic)

Gneiss and quartzite with marble layers (Archean)

Granite and pegmatite (Late Archean)

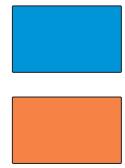

Pyroxenite

Dunite

Figure 25. Schematic geologic map of the Kondyor maficultramafic intrusion, central part of Russian Far East. The platinumgroup minerals occur as disseminated (widely-spaced) minerals in the circular and zoned mafic (magnesium- and iron rich) pluton. Adapted from Nokleberg and others (2003). 


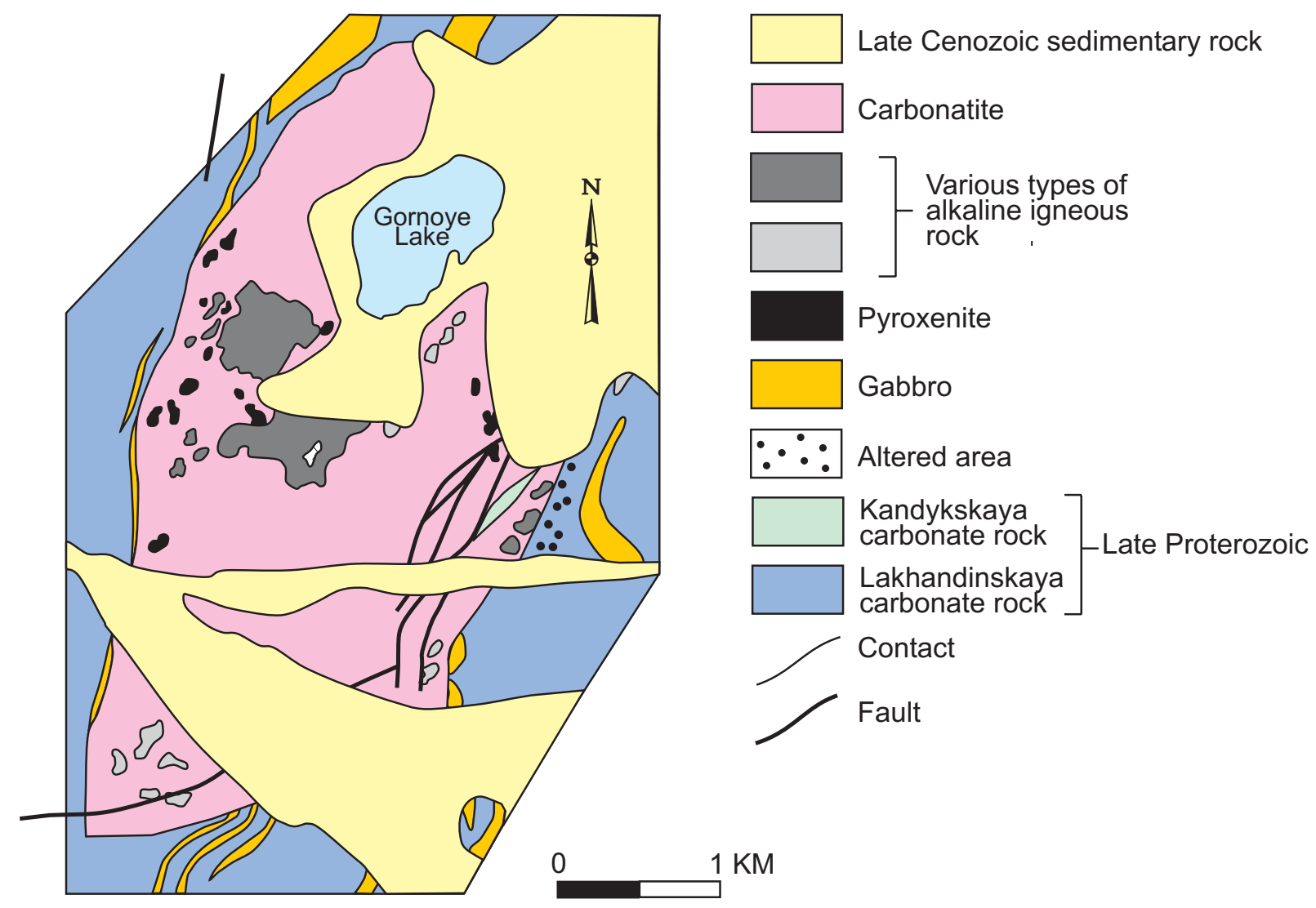

Figure 26. Schematic geologic map of the Gornoye Ozero carbonatite-related rare-earth metal deposit, Russian Northeast. The rare-earth minerals occur as disseminations (widely-spaced minerals) in the alkaline igneous and related rock. Adapted from Korostelev (1982). 


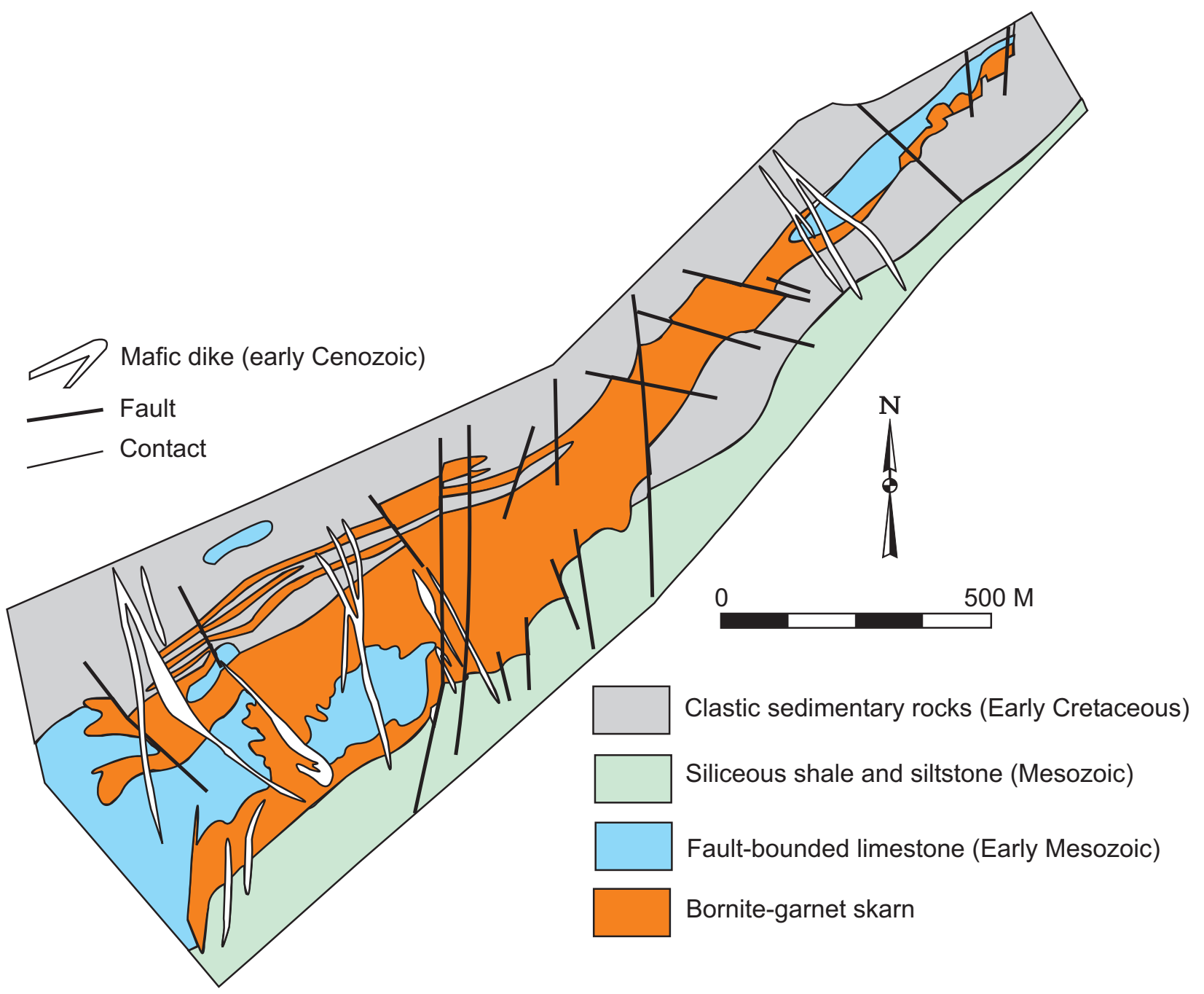

Figure 27. Schematic geologic map of Dalnegorsk boron skarn deposit in Russian Southeast. The boron minerals (datolite and danburite) occur in skarn that formed from hydrothermal alteration of limestone. Adapted from Shkolnik and others, 2003). 


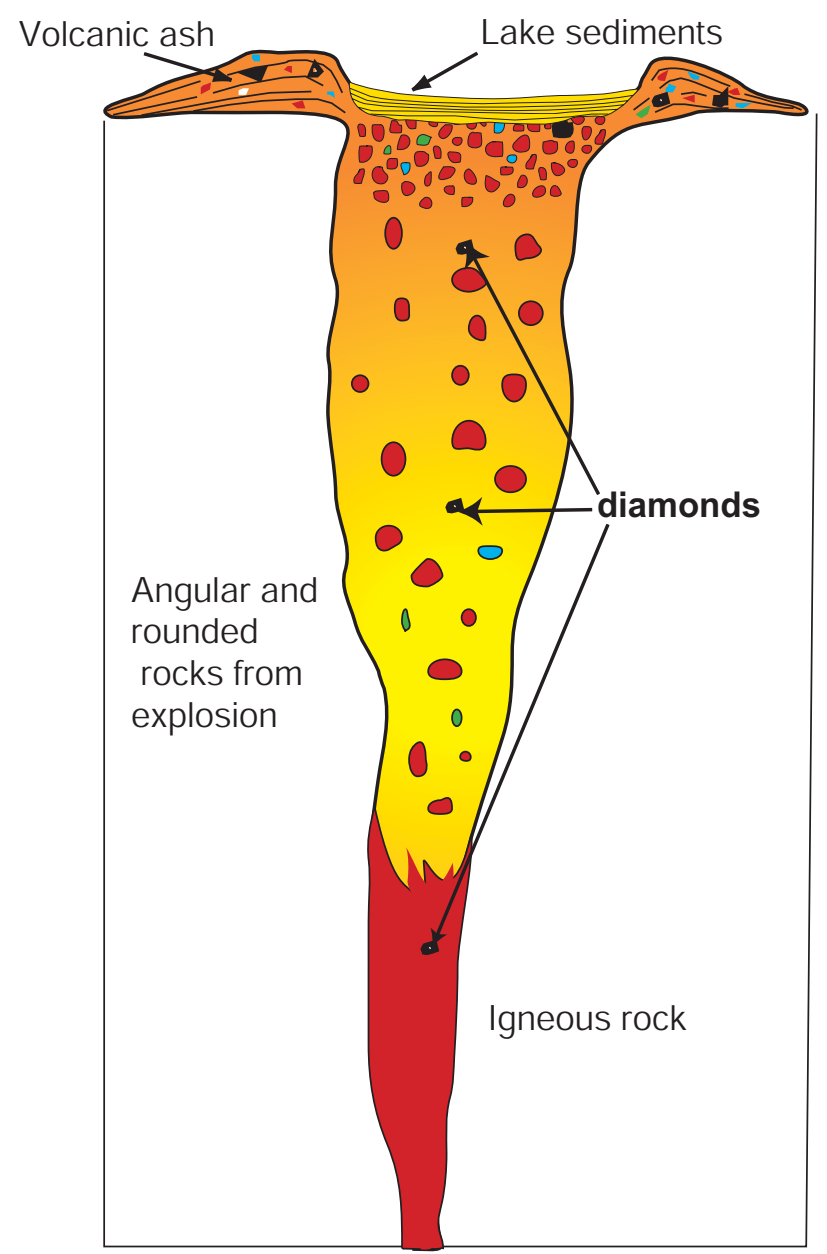

Figure 28. Schematic cross section illustrating model for formation of a diamond kimberlite pipe. These pipes form by explosive processes that originate in the Earth's mantle where pressures and temperatures are high enough to form diamonds. The diamonds are associated with a particular type of dark rock called a kimberlite. Adapted from Cunningham and others (this volume). 


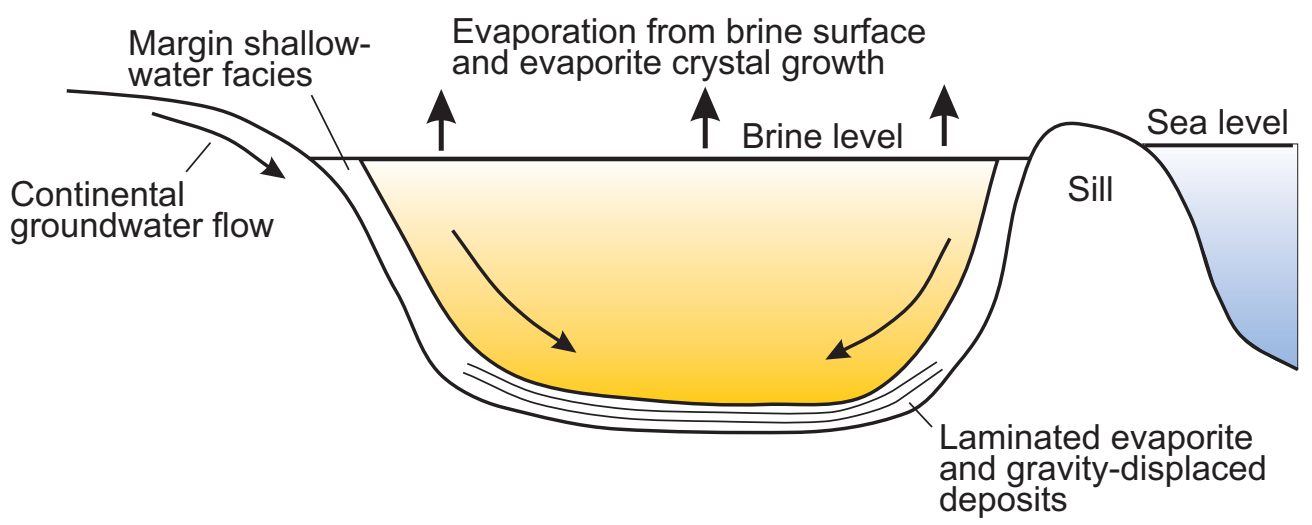

A. Deep-water, deep basin model

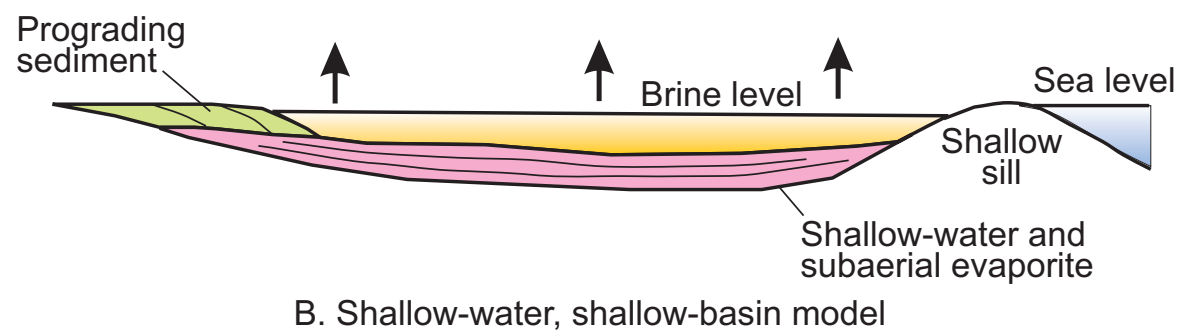

Figure 29. Schematic cross section illustrating model for formation of sedimentary potash deposits. The potash minerals form as precipitates in the bottom of an evaportie brine basin. Adapted from Boggs (1987). 